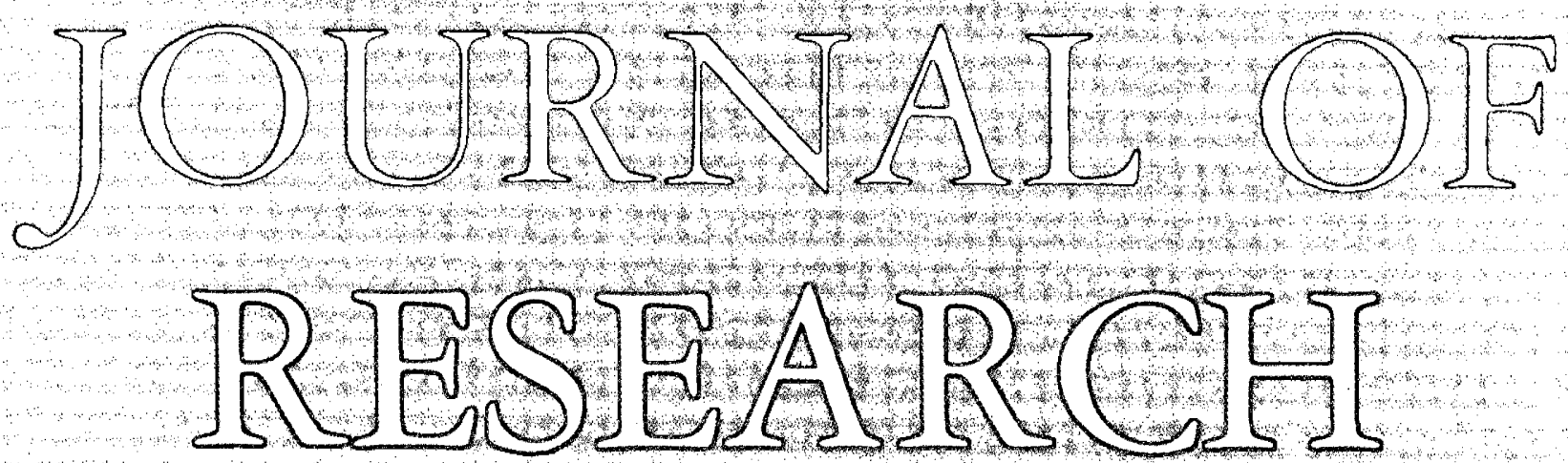

OF THE U.S. GEOLOGICAI SURVEY

JULY-AUGUST 1976

VOLUME 4, NUMBER 4

Scientific notes and summaries

of investigations in geology,

bydrology, and related fields

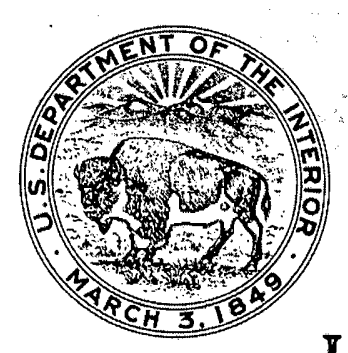

U.S. DEPARTMENT OF THE INTERIOR 


\section{UNITED STATES DEPARTMENT OF THE INTERIOR \\ THOMAS S. KLEPPE, Secretary \\ GEOLOGICAL SURVEY}

V. E. McKelvey, Director

For sale by the Superintendent of Documents, U.S. Government Printing Office, Washington, DC 20402. Annual subscription rate $\$ 18.90$ (plus $\$ 4.75$ for foreign mailing). Single copy $\$ 3.15$. Make checks or money orders payable to the Superintendent of Documents.

Send all subscription inquiries and address changes to the Superintendent of Documents at the above address.

Purchase orders should not be sent to the U.S. Geological Survey library.

Library of Congress Catalogcard No. 72-600241.
The Journal of Research is published every 2 months by the U.S. Geological Survey. It contains papers by members of the Geological Survey and their professional colleagues on geologic, hydrologic, topographic, and other scientific and technical subjects.
Correspondence and inquiries concerning the Journal (other than subscription inquiries and address changes) should be directed to Anna $M$. Orellana, Managing Editor, Journal of Research, Publications Division, U.S. Geological Survey, 321 National Center, Reston, VA 22092.

Papers for the Journal should be submitted through regular Division publication channels.

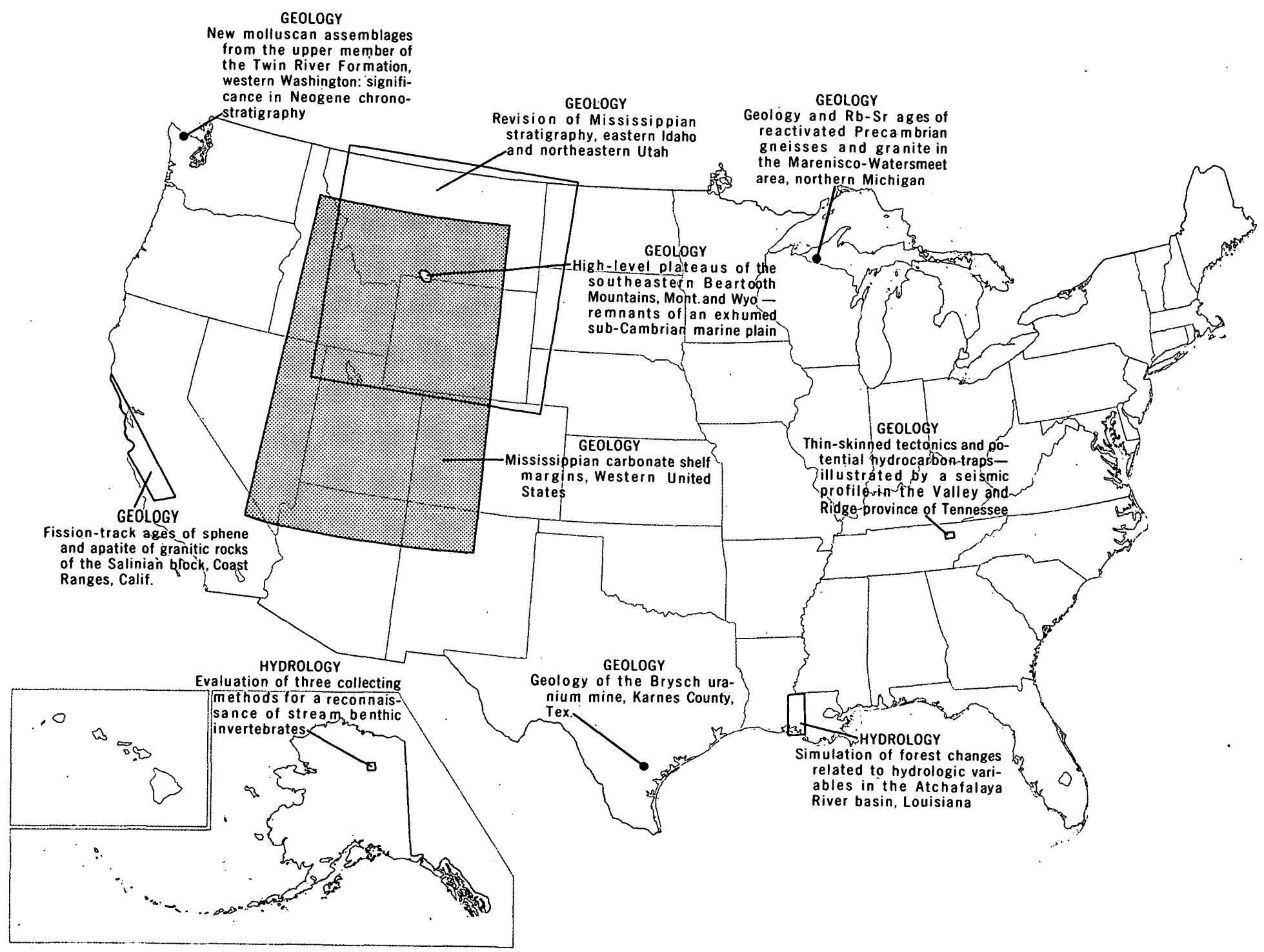

The Secretary of the Interior has determined that the publication of this periodical is necessary in the transaction of the public business required by law of this Department. Use of funds for printing this periodical has been approved by the Director of the Office of Management and Budget through June 30, 1980. 


\title{
JOURNAL OF RESEARCH
}

\author{
of the
}

U.S. Geological Survey

Vol. 4 No. 4

July-Aug. 1976

\section{CONTENTS}

Abbreviations.

II

Metric-English equivalents.

II

\section{GEOLOGIC STUDIES}

Thin-skinned tectonics and potential hydrocarbon traps-illustrated by a seismic profle in the Valley and Ridge province of Tennessee.-

High-level plateaus of the southeastern Beartooth Mountains, Mont. and Wyo-remnants of an exhumed sub-Cambrian marine plain_-_-_._..... S. Simons and T. J. Armbrustmacher

Geology of the Brysch uranium mine, Karnes County, Tex_-__-_. A. Dickinson and M. W. Sullivan

Geology and $\mathrm{Rb}-\mathrm{Sr}$ ages of reactivated Precambrian gneisses and granite in the Marenisco-Watersmeet area, northern Michigan._-_. Sims and $Z$. E. Peterman

Fission-track ages of sphene and apatite of granitic rocks of the Salinian block, Coast Ranges, Calif - Noss

Revision of the Carboniferous genus Aulina Smith (Coelenterata, Anthozoa) -_-_-_...W. J. Sando

New molluscan assemblages from the upper member of the Twin River Formation, western Washington: significance in Neogene chronostratigraphy

Mississippian carbonate shelf margins, Western United States

Revision of Mississippian stratigraphy, eastern Idaho and northeastern Utah

W. J. Sando, J. T. Dutro, Jr., C. A. Sandberg, and B. L. Mamet

\section{HYDROLOGIC STUDIES}

Simulation of forest changes related to hydrologic variables in the Atchafalaya River basin. Louisiana.-. Jennings and $C$. $P$. O'Neil

Evaluation of three collecting methods for a reconnaissance of stream benthic invertebrates.-----K. V. Slack, J. W. Nauman, and L. J. Tilley evaluation of methods for measuring algal growth

W. T. Shoaf and B. W. Lium 


\section{ABBREVIATIONS}

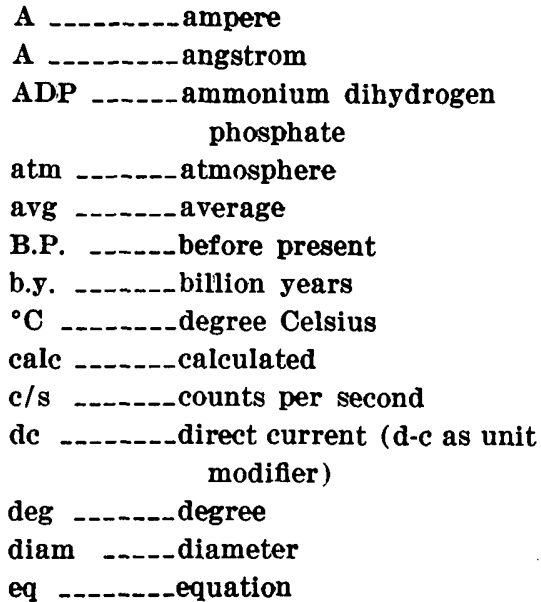

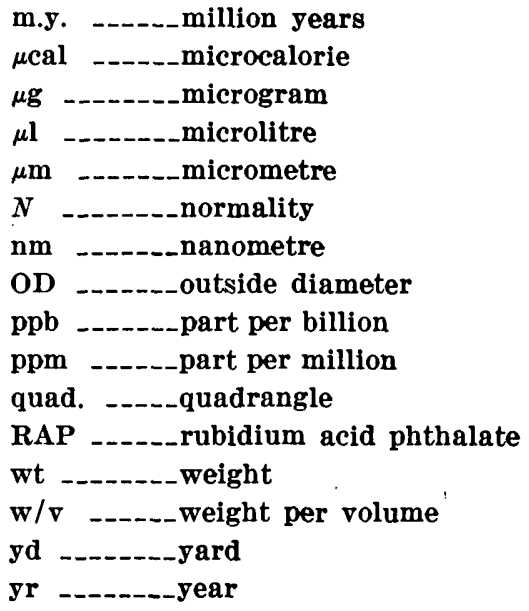

\section{METRIC-ENGLISH EQUIVALENTS}

\begin{tabular}{|c|c|c|c|c|c|c|}
\hline Metric unit & \multicolumn{3}{|c|}{ English equivalent } & \multicolumn{3}{|c|}{ English equivalent } \\
\hline \multicolumn{4}{|c|}{ Length } & \multicolumn{3}{|c|}{ Specific combinations-Continued } \\
\hline $\begin{array}{l}\text { millimetre }(\mathrm{mm}) \\
\text { metre (m) } \\
\text { kilometre (km) }\end{array}$ & $\begin{array}{l}= \\
\equiv \\
=\end{array}$ & $\begin{array}{l}0.03937 \\
3.28 \\
.62 \\
\end{array}$ & $\begin{array}{l}\text { Inch (in) } \\
\text { feet (ft) } \\
\text { mile (mi) }\end{array}$ & \multirow{5}{*}{$\begin{array}{l}\text { cubic metre per second } \\
\text { per square kilometre } \\
{\left[\left(\mathrm{m}^{3} / \mathrm{s}\right) / \mathrm{km}^{2}\right]} \\
\text { metre per day (m/d) } \\
\text { metre per kilometre } \\
(\mathrm{m} / \mathrm{km}) \\
\text { kilometre per hour } \\
(\mathrm{km} / \mathrm{h}) \\
\text { metre per second (m/s) } \\
\text { metre squared per day } \\
\left(\mathrm{m}^{2} / \mathrm{d}\right)\end{array}$} & \multirow{2}{*}{$\begin{array}{l}=91.47 \\
=3.28\end{array}$} & \multirow{2}{*}{$\begin{array}{l}\text { cubic feet per second per } \\
\text { square mile }\left[\left(\mathrm{ft}^{3} / \mathrm{s}\right) / \mathrm{mi}^{2}\right] \\
\text { feet per day (hydraulic } \\
\text { conductivity) (ft/d) }\end{array}$} \\
\hline \multicolumn{4}{|c|}{ Area } & & & \\
\hline $\begin{array}{l}\text { square metre }\left(\mathrm{m}^{2}\right) \\
\text { square kllometre }\left(\mathrm{km}^{2}\right) \\
\text { hectare (ha) } \\
\end{array}$ & & $\begin{array}{c}10.76 \\
.386 \\
2.47 \\
\end{array}$ & $\begin{array}{l}\text { square feet }\left(\mathrm{ft}^{2}\right) \\
\text { square mile }\left(\mathrm{mi}^{2}\right) \\
\text { acres }\end{array}$ & & $=5.2 \mathrm{~S}$ & feet per mlle $(\mathrm{ft} / \mathrm{ml})$ \\
\hline \multicolumn{4}{|c|}{ Volume } & & $=. .9113$ & $\begin{array}{l}\text { foot per second }(\mathrm{ft} / \mathrm{s}) \\
\text { feet per second }\end{array}$ \\
\hline $\begin{array}{l}\text { cubic centimetre }\left(\mathrm{cm}^{3}\right) \\
\text { litre (l) } \\
\text { cubic metre }\left(\mathrm{m}^{3}\right)\end{array}$ & & $\begin{array}{l}0.061 \\
61.03 \\
35.31 \\
.00081\end{array}$ & $\begin{array}{l}\text { cubic inch }\left(\mathrm{fn}^{3}\right) \\
\text { cubic inches } \\
\text { cubic feet }\left(\mathrm{ft}^{3}\right)\end{array}$ & & $=10.764$ & $\begin{array}{l}\text { feet squared per day }\left(\mathrm{ft}^{2} / \mathrm{d}\right) \\
\text { (transmissivity) }\end{array}$ \\
\hline $\begin{array}{l}\text { cublc metre } \\
\text { cublc hectometre }\left(\mathrm{hm}^{3}\right) \\
\text { litre }\end{array}$ & $\begin{array}{l}= \\
\equiv \\
\equiv\end{array}$ & $\begin{array}{l}.00081 \\
2.113 \\
1.06\end{array}$ & $\begin{array}{l}\text { acre-foot (acre-ft) } \\
\text { acre-feet } \\
\text { pints (pt) }\end{array}$ & \multirow{6}{*}{$\begin{array}{l}\text { cuble metre per second } \\
\left(\mathrm{m}^{3} / \mathrm{s}\right) \\
\text { cubic metre per minute } \\
\left(\mathrm{m}^{3} / \mathrm{min}\right) \\
\text { litre per second }(\mathrm{l} / \mathrm{s}) \\
\text { litre per second per } \\
\text { metre }[(\mathrm{l} / \mathrm{s}) / \mathrm{m}] \\
\text { kilometre per hour } \\
\text { ( } \mathrm{km} / \mathrm{h}) \\
\text { metre per second }(\mathrm{m} / \mathrm{s}) \\
\text { gram per cuble } \\
\text { centimetre }\left(\mathrm{g} / \mathrm{cm}^{3}\right) \\
\text { gram per square } \\
\text { centimetre }\left(\mathrm{g} / \mathrm{cm}^{2}\right) \\
\text { gram per square } \\
\text { centimetre }\end{array}$} & $=22.826$ & $\begin{array}{l}\text { millifon gallons per day } \\
(\text { Mgal/d) }\end{array}$ \\
\hline & & & $\begin{array}{l}\text { quarts (qt) } \\
\text { gallon (gal) }\end{array}$ & & $=264.2$ & gallons per minute (gal/min) \\
\hline $\begin{array}{l}\text { cublc metre } \\
\text { cublc metre } \\
\end{array}$ & & $\begin{array}{l}.00026 \\
6.290 \\
\end{array}$ & $\begin{array}{l}\text { million gallons (Mgal or } \\
10^{8} \text { gal) } \\
\text { barrels (bbl) (1 bbl =42 gal) }\end{array}$ & & $\begin{array}{l}=15.85 \\
=4.83\end{array}$ & $\begin{array}{l}\text { gallons per minute } \\
\text { gallons per minute per foot }\end{array}$ \\
\hline & & Weight & & & $=$ & mile per hour $(\mathrm{mi} / \mathrm{h})$ \\
\hline $\begin{array}{l}\text { gram }(g) \\
\text { gram } \\
\text { tonne }(t) \\
\text { tonne }\end{array}$ & & $\begin{array}{l}0.035 \\
.0022 \\
1.1 \\
.98 \\
\end{array}$ & $\begin{array}{l}\text { ounce, avoirdupois (oz ardp) } \\
\text { pound, avoirdupois (lb avdp) } \\
\text { tons, short }(2,000 \mathrm{lb}) \\
\text { ton, long }(2,240 \mathrm{lb})\end{array}$ & & $\begin{array}{l}=2.237 \\
=62.43 \\
=2.048\end{array}$ & $\begin{array}{l}\text { miles per hour } \\
\text { pounds per cubic foot }\left(\mathrm{lb} / \mathrm{ft}^{3}\right) \\
\text { pounds per square foot }\left(\mathrm{lb} / \mathrm{ft}^{2}\right)\end{array}$ \\
\hline \multicolumn{4}{|c|}{ Specific combinations } & & $=.0142$ & pound per square Inch $\left(1 b / \ln ^{2}\right)$ \\
\hline $\begin{array}{l}\text { kllogram per square } \\
\text { centimetre }\left(\mathrm{kg} / \mathrm{cm}^{2}\right)\end{array}$ & & 0.96 & atmosphere (atm) & \multicolumn{3}{|c|}{ Temperature } \\
\hline $\begin{array}{l}\text { kllogram per square } \\
\text { centimetre } \\
\text { cubic metre per second } \\
\left(\mathrm{m}^{3} / \mathrm{s}\right)\end{array}$ & $\begin{array}{l}= \\
=\end{array}$ & $\begin{array}{l}.98 \\
35.3\end{array}$ & $\begin{array}{l}\text { bar }(0.9 S 69 \mathrm{~atm}) \\
\text { cubic feet per second }\left(\mathrm{ft}^{3} / \mathrm{s}\right)\end{array}$ & $\begin{array}{l}\text { degree Celsius }\left({ }^{\circ} \mathrm{C}\right) \\
\text { degrees Celsius } \\
\text { (temperature) }\end{array}$ & $\begin{array}{l}=1.8 \\
=\left[\left(1.8 \times{ }^{\circ} \mathrm{C}\right)\right.\end{array}$ & $\begin{array}{l}\text { degrees Fahrenheit }\left({ }^{\circ} \mathrm{F}\right) \\
+32 \text { ] degrees Fahrenheit }\end{array}$ \\
\hline
\end{tabular}

Any use of trade names and trademarks in this publication is for descriptive purposes only and does not constitute endorsement by the U.S. Geological Survey. 


\title{
THIN-SKINNED TECTONICS AND POTENTIAL HYDROCARBON TRAPS- ILLUSTRATED BY A SEISMIC PROFILE IN THE VALLEY AND RIDGE PROVINCE OF TENNESSEE
}

\author{
By LEONARD D. HARRIS, Knoxville, Tenn.
}

\begin{abstract}
Seismic data, although limited to a small part of the western half of the Valley and Ridge province in Tennessee, confirm that the structural style is thin-skinned and that there is a fundamental change from west to east in both the total section preserved and the structural complexities that exist in the subsurface. Cambrian to Upper Ordovician rocks in the Valley and Ridge province have been thrust westward over a 4-mile $(6.4-\mathrm{km})$ projection of Cambrian through Mississippian rocks of the Appalachian Plateau. Structure within the plateau projection is characterized by splay anticlines, whereas structure in the Valley and Ridge is dominated by a series of imbricate thrust sheets containing isolated faultbound masses of Cambrian sandstone and shale. Both splay anticlines and large fault-bound masses of rocks preserved in the subsurface in east Tennessee may be favorable fractureporosity traps for the accumulation of hydrocarbons.
\end{abstract}

Field studies of the Pine Mountain thrust sheet in Kentucky, Virginia, and Tennessee, from 1920 to the late 1940's, led to the concept that thin-skinned tectonics was the dominant style of deformation in the complexly thrust-faulted southern Valley and Ridge province (Wentworth, 1921; Butts, 1927; Rich, 1934; Rodgers, 1949; Miller and Fuller, 1954). Advocates of this concept suggested that the Paleozoic sedimentary prism had been stripped from basement and moved many miles northwestward by a series of great thrust faults. These faults, taking advantage of lithologic contrasts in rocks, formed as nearly flat-lying beddingplane thrusts in incompetent rocks and ramped steeply upward across competent rocks. Movement of thrust sheets up and over ramp zones produced major rootless folds by simple duplication of beds. Subsurface data from oil and gas test holes in and adjacent to the southern Valley and Ridge (Harris, 1970; Miller, 1973) have partly confirmed the general characteristics of thinskinned tectonics as outlined by the earlier workers. A more positive confirmation was realized in 1974 when Geophysical Services, Inc., released to the public domain a $20-\mathrm{mi}(32-\mathrm{km})$ segment of a migrated vibroseis seismic profile in the Valley and Ridge between the towns of Kingston and Dixie Lee Junction, Tenn. (fig. 1). This important profile clearly demonstrates for the first time in the southern Valley and Ridge the characteristic "sledrunner" thrust-fault signature of thinskinned tectonics (fig. 2). Major reflectors in the Rome Formation (Lower Cambrian) can be seen to dip steeply southeastward from the outcrop and to decrease gradually in dip in the subsurface to where they merge with a nearly flat-lying décollement zone.

My personal experience with seismic interpretation is limited, but because of my familiarity with the details of the geology of the area, I thought that it might be of interest to illustrate a geologist's point of view in an interpretation of a seismic profile in the southern Valley and Ridge. Because several geophysical variables were not considered in my interpretation, the structure as depicted should not be accepted in detail. Instead, the structural interpretation presented herein is intended to serve only as a model that perhaps furnishes insight into the expectable general subsurface condition in the southern Valley and Ridge province.

\section{INTERPRETATION}

At the surface, the seismic profile released by Geophysical Services, Inc., transects a stratigraphic sequence limited to three contrasting lithologic units of Cambrian to Upper Ordovician age (figs. 1 and 3). Vertically, the sequence includes, from the base up: the Rome Formation (a Lower Cambrian sandstone and shale unit), the Conasauga Shale (a Middle and Upper Cambrian shale and a thin limestone unit), and the Knox Group and Chickamauga Limestone, undivided (an Upper Cambrian to Upper Ordovician carbonate unit). All or parts of this sequence are repeated five times on the surface because of thrust faulting. A careful analysis of the repeated sections indicates that each contrasting lithologic unit of Cam- 

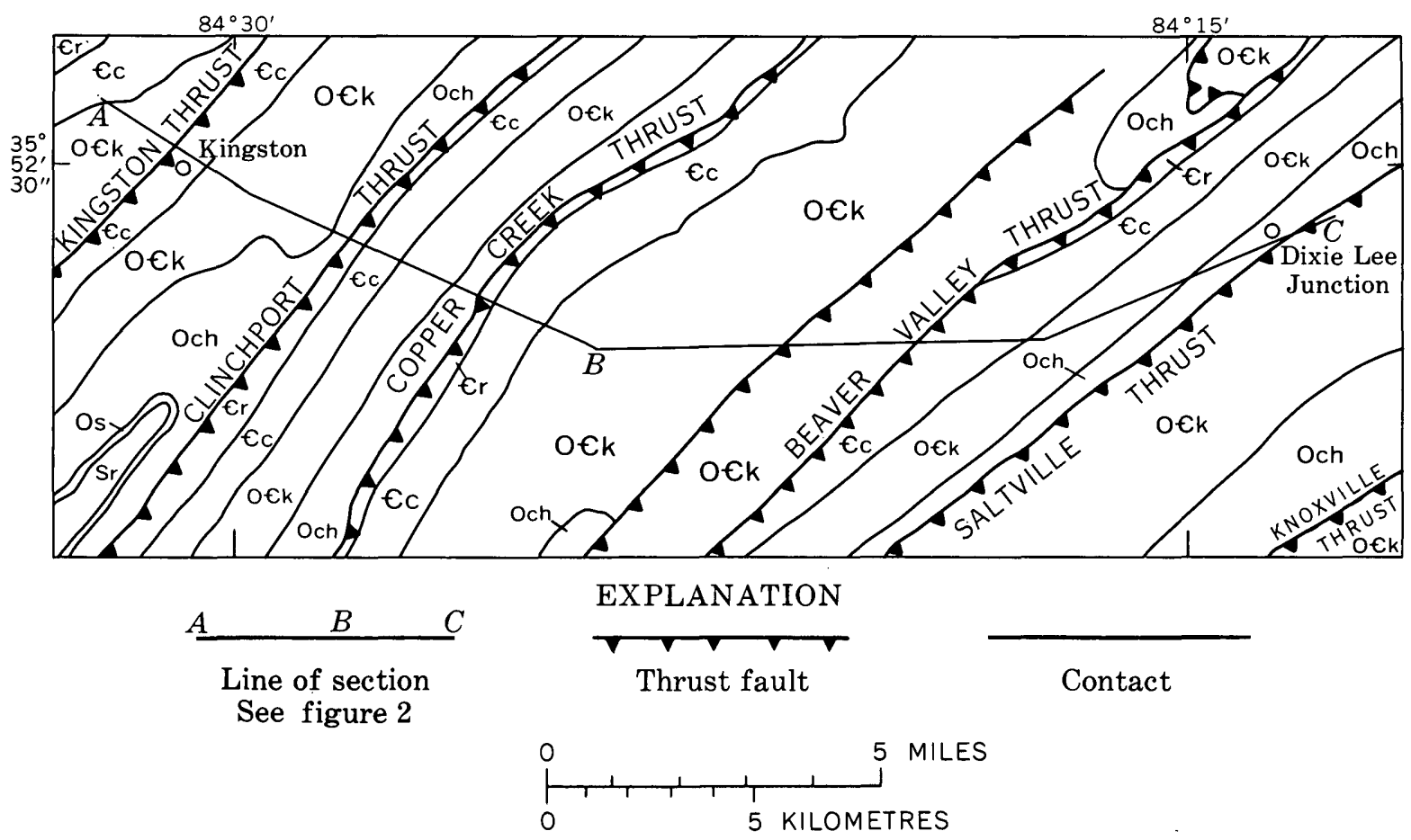

Fraure 1.-Index map showing the trend of the Geophysical Services, Inc., seismic profle in relation to the general structural grain of the Valley and Ridge province in part of east Tennessee. Segment $A-B$ is normal to the structural grain; segment $B-C$ trends obliquely to the grain $€ r$, Rome Formation ; $€ c$, Conasauga Shale; OCk, Knox Group; Och, Chickamauga Limestone; Os, Sequatchie Formation; Sr, Rockwood Formation. Outline of index map shown by dashed line on the generalized geologic map (fig. 4).

brian to Upper Ordovician age consistently produces a distinct recognizable seismic pattern. In addition, two other distinct seismic patterns were found to be restricted to the subsurface. The five major seismic signatures recognized include (fig. 3 ) :

1. A basement pattern, which is characterized by a lack of through-going readily distinguishable reflector horizons.

2. Rome Formation pattern, which is characterized by a series of strong, nearly continuous heavy lines.

3. Conasauga Shale pattern, which tends to resemble a series of discontinuous ripple marks.

4. Knox Group and Chickamauga Limestone sequence undivided pattern, which resembles a discontinuous standard sandstone symbol.

5. An Upper Ordovician through Mississippian pattern, which resembles a coarse sandstone symbol arranged in a series of definite layers.

In utilizing the five patterns to interpret structures in the seismic profile, it became apparent that the major Cambrian through Upper Ordovician units selected appeared to increase in thickness toward the east (fig. 2 ). Surface measurements show that the thickness of this sequence ranges from about $7,000 \mathrm{ft}(2,100 \mathrm{~m})$ on the west to about $8,600 \mathrm{ft}(2,580 \mathrm{~m})$ on the east. In addition, an apparent thickening occurs in the eastern two-thirds of the profile, segment $B-C$, because the trend of that part of the seismic line is oblique to the structural grain of the Valley and Ridge (fig. 1). Although superficially, seismic profiles oriented at an angle to the structural grain may seem to be of minimum value, this is not necessarily true. Instead, this orientation has the added advantage of allowing the geologist to view different perspectives of the subsurface in a single seismic profile. Segment $A-B$ of the profile illustrates a normal or near normal cross-sectional view ; segment $B-C$ shows the longitudinal characteristics of thrust sheets and demonstrates their lateral continuity (fig. 2).

In the past, because of limited subsurface control, most structural interpretations in the Valley and Ridge of east 'Tennesee have been based on the extrapolation of surface features into the subsurface (summarized by Rodgers, 1970). The structural style shown in these sections is based on the characteristics commonly attributed to thin-skinned tectonics. Thus, deformation is interpreted to be confined to the sedimentary sequence above basement and to consist of a series of major thrust faults that join a master décollement at or near the sedimentary rock-basement inter- 

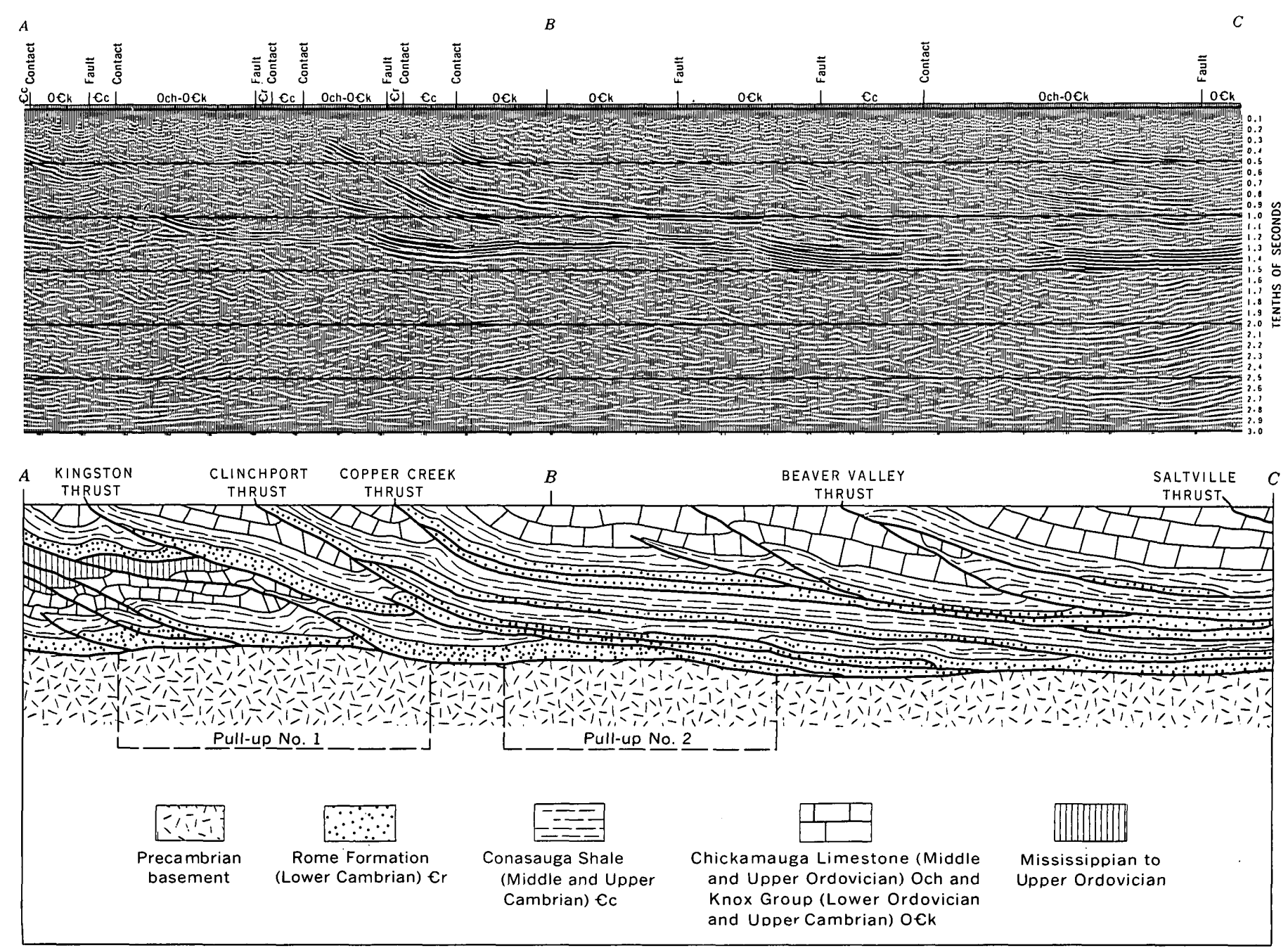

Figure 2.- Seismic profle (upper) and interpretive structure section (lower). Rectangular areas designated by dashed line and labeled "pull-up No. 1" and "pull-up No. 2" are probably acoustically produced warps in the basement surface related to velocity contrasts. The location of line $A-B-C$ is shown in figure 1.

face. The geometry and space relation shown in the seismic profile and my interpreted structure section (fig. 2) confirm that the style of deformation in east Tennessee is thin-skinned. In addition, these same data point out that because of the lack of subsurface control, most previous interpretations are simply generaljzations of the complexities that exist in the subsurface. The availability of subsurface control affords the opportunity to scrutinize rigorously some of the basic assumptions of thin-skinned tectonics. Accordingly, three of the major characteristics commonly attributed to thin-skinned deformation are considered in the following:

\section{Deformation confined to the sedimentary sequence and little or no basement involvement}

The interpreted contact between basement and the overlying sedimentary sequence in the seismic profile appears to be warped into a series of broad folds (fig. 2 ). Because the seismic profile is a time section, these folds, which seem to involve basement, are probably acoustically produced pull-ups related to the contrasts in relative velocities of energy impulses in different rock units. Estimated velocities for the Cambrian to Upper Ordovician rock units range from about 14,000 $\mathrm{ft}(4,200 \mathrm{~m})$ per second for the Conasauga Shale, about $17,000 \mathrm{ft}(5,100 \mathrm{~m})$ per second for the Rome Formation, to about $20,000 \mathrm{ft}(6,000 \mathrm{~m})$ per second for the carbonates of the Knox Group and Middle Ordovician. Consequently, the profile tends to expand vertically over areas in the subsurface where structural conditions have overthickened units of lower velocity, simply because in those areas a greater time interval is necessary for energy to travel down and back to the surface. Conversely, the vertical section tends to thin over areas where the higher velocity carbonate unit is 


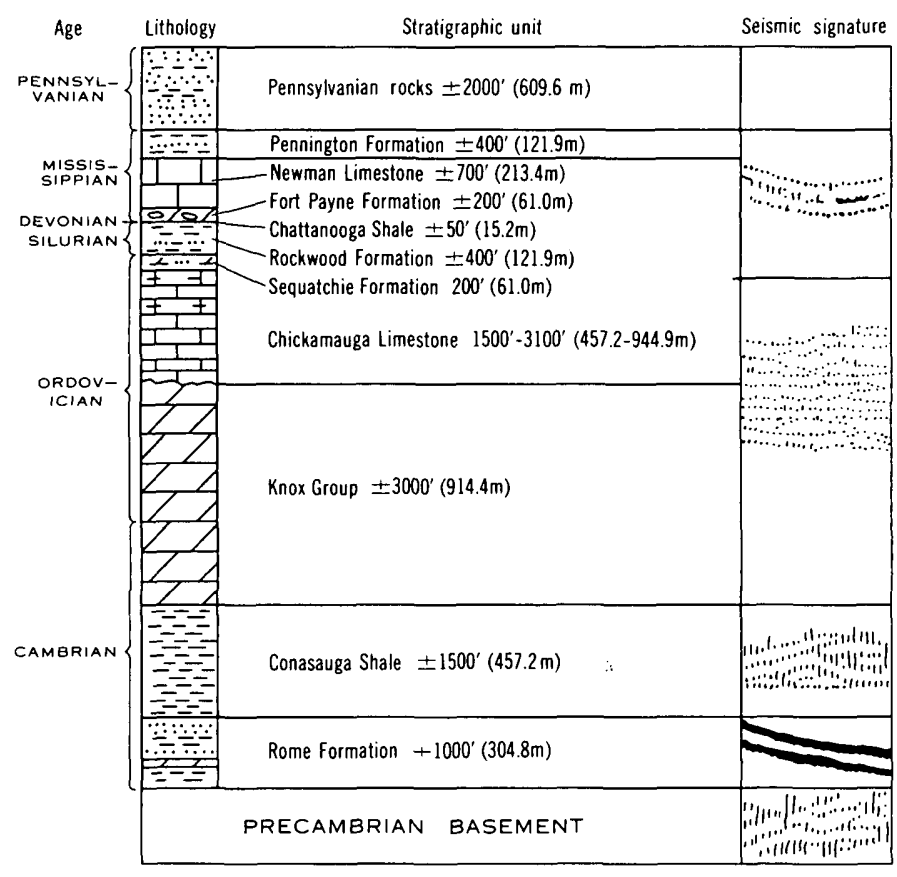

Figure 3.-Generalized stratigraphic section in the area traversed by the seismic profile.

structurally overthickened, because in those areas a shorter time interval is required for energy to travel down and back to the surface. As a result of major subsurface duplication, the contact between basement and the overlying sedimentary sequence appears to be warped into two broad pull-ups. Pull-up No. 1, in the western fourth of the profile, occurs where there is major duplication, both on the surface and in the subsurface, of high-velocity carbonate. This pull-up is accentuated by tectonic thickening of the lower velocity Rome Formation on either limb. Pull-up No. 2, a smaller feature near the center of the profile, appears to be related mainly to the pile-up of lower velocity Rome on both limbs and minor duplication of carbonate in the upper part of the profile.

Other than pull-ups, which are adequately explained as velocity contrasts accentuated by tectonic overthickening of individual lithologies, no structural features present in the sedimentary sequence are observed to affect basement. Apparently basement within this profile was not involved during deformation.

\section{Presence of a master décollement}

The seismic profile and the interpreted structure section show that the major reflector (the Rome Formation) dips southeast from the surface and joins a master décollement zone at or near the sedimentary rockbasement interface. The seismic character of the Rome
Formation immediately above the basal décollement suggests that the Rome is progressively overthickened tectonically from west to east. In the western half of the profile, the Rome forms a nearly continuous unit within which overthickening is a local phenomenon accomplished by splay thrusting. In contrast, the Rome interval in the middle and eastern part of the profile is a series of duplicated slabs. Apparently the development of local obstructions within the décollement zone during movement resulted in a minor deflection of the thrust fault upward to the top of the Rome, where the fault again becomes a bedding-plane thrust in the basal part of the Conasauga Shale. Continuing movement resulted in subsurface duplication and abandonment of large masses of the Rome and some Conasauga Shale. This same process appears to have been operative on most major thrust faults, even above the décollment.

Subsurface stacking and abandonment of large masses of the Rome Formation have had a profound effect on the distribution and thickness of the Rome on the surface in Tennessee. In the Valley and Ridge, displacement along most major thrust faults is scissorlike: it increases along strike toward the southwest. This increase is accompanied by a gradual decrease in the outcrop width of the Rome directly above major thrust faults (fig. 4). For example, the Rome is present above the Beaver Valley thrust, just north of Knoxville where the displacement begins. As displacement on the thrust increases toward the southwest, surface exposure of the Rome gradually tectonically thins to extinction. The same distribution pattern of the Rome can be seen from northwest to southeast normal to the structural grain of the Valley and Ridge. In general, the westernmost thrust sheets have the most continuous and widest outcrop pattern for the Rome. The outcrop pattern thins progressively eastward so that in the central and easternmost thrust sheets, the outcropping Rome is discontinuous or completely missing. This west-to-east tectonic thinning of the Rome tends to confirm Miller (1973) and Milici's (1975) suggestion that the orogenic cycle in the Valley and Ridge began with the formation of a single master plate which later imbricated from west to east. Milici has based his interpreted west-to-east sequential development of thrusting on the fact that throughout the southern Appalachians, many major thrust faults have been overridden and buried from the east by the next succeeding thrust fault. This type of structural relationship is evident in the area shown in the northeastern quarter of figure 4 where the Wallen Valley thrust has been overridden and buried from the east by the Clinchport thrust. For this kind of burial process to be operative 


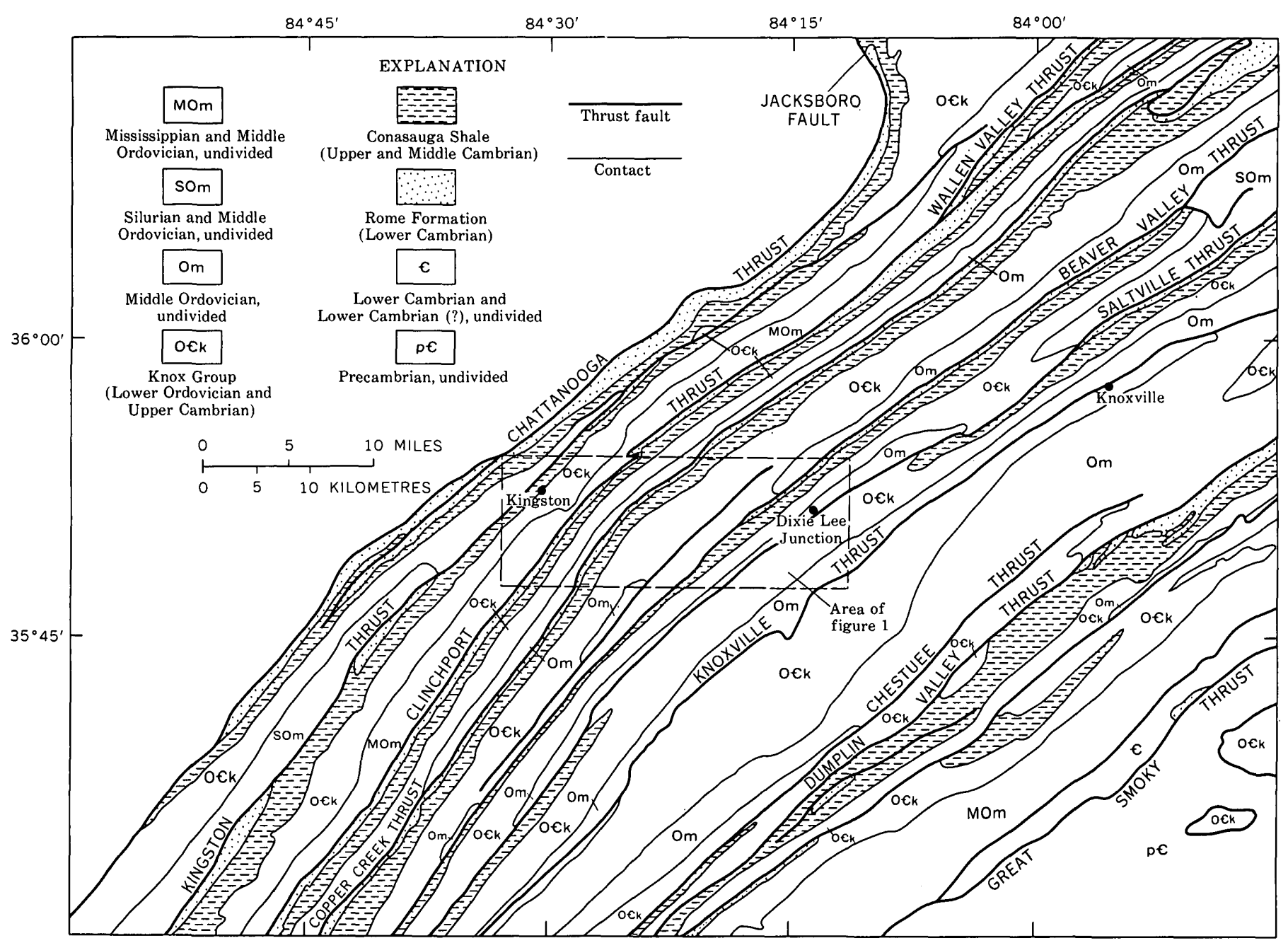

Frgure 4.-Generalized geologic map showing the distribution of the Rome Formation and the Conasauga Shale.

throughout the southern Appalachians, movement must have ceased on all overridden thrust faults in a westto-east sequence. Because movement ceased on the westernmost faults early in the sequential development of structure, these thrust faults have the least displacement and the greatest amount of preserved Rome. In contrast, the central and easternmost thrust faults, because of the accumulative effect of displacement on each succeeding thrust fault, have the greater displacement and the least amount of preserved Rome.

\section{Formation of thrust faults}

Regional structural analysis (Milici, 1975) and the relationship between the distribution of the Rome Formation and the amount of accumulative displacement on thrust faults, discussed earlier in this report, suggest that the orogenic cycle in the Valley and Ridge of east Tennessee began with the regional formation of a single master plate moving above a basal décollement (fig. 5). Apparently, minor splay thrusting distorted the décollement zone near the west edge of the Valley and Ridge, where perhaps low confining pressures associated with relatively shallow depth of burial resulted in the deforming forces exceeding the shearing strength of the rocks. Continuing development of these subsurface obstructions caused the master plate to begin imbricating from west to east. Movement along the first imbricate thrust fault produced a large rootless anticline simply by duplication of beds. The geometry and space relations of this first imbricate thrust and its associated fold are identical with relationships predicted by earlier workers (Rodgers, 1949) for thrust faults that form in relatively undeformed rocks early in the orogenic cycle. In contrast, the geometry and space relations of the later developing imbricate thrusts are strongly influenced by the fact that the faults originate in deformed rocks at points of maximum stress where space problems exist. Space problems (deSitter, 1956; Gwinn, 1964) are created in the moving plate by drag where the edges of formations abut 
against the thrust surface, thereby tightening the developing rootless fold, and in areas where the moving plate is warped over the diagonal ramp zone in the autochthonous plate. Once the imbrication process is set in motion, the same factors that contribute to space problems tend to be repeated, so that as each space
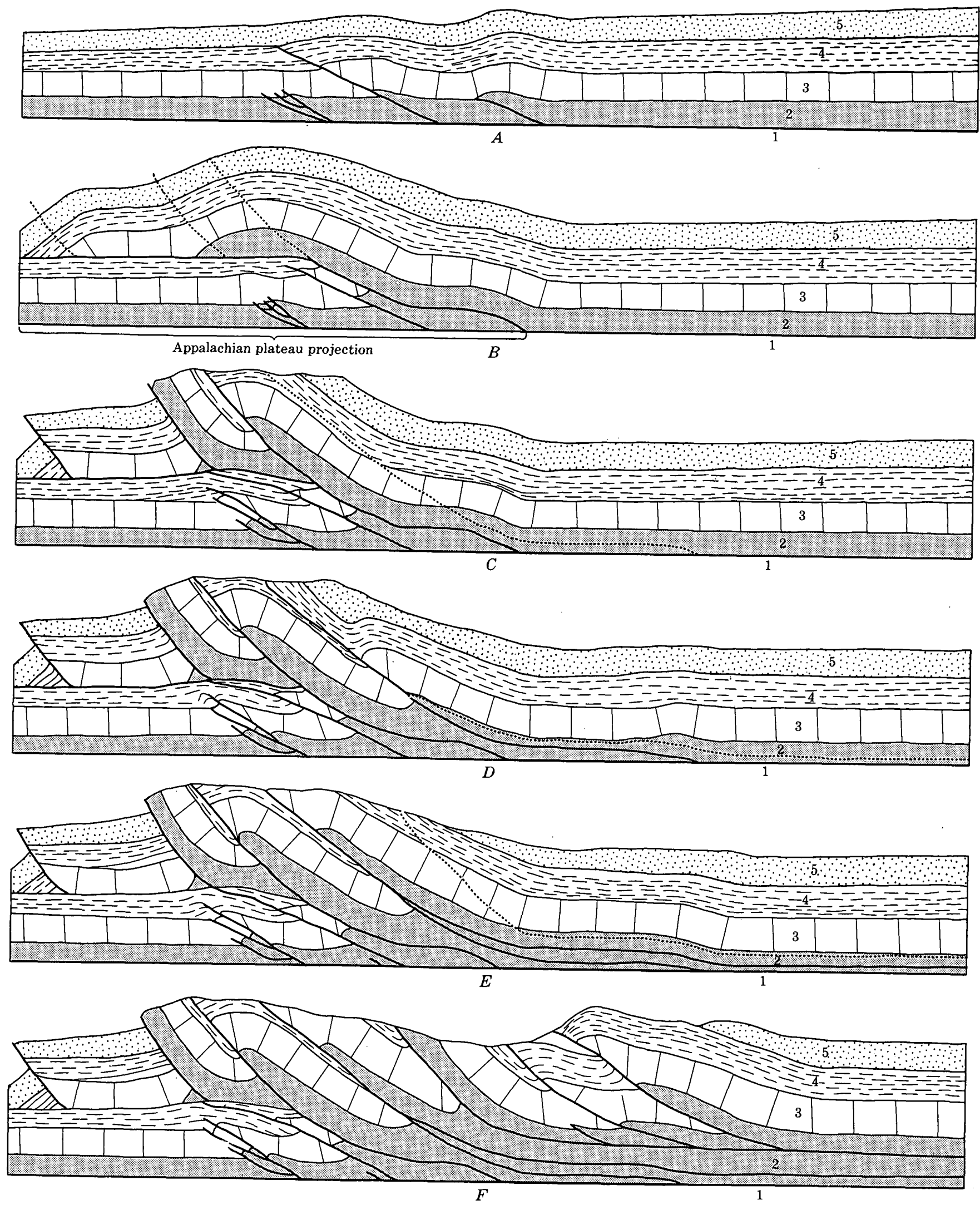
problem is resolved by thrusting, the process of imbrication shifts from west to east.

\section{POSSIBLE HYDROCARBON TRAPS IN THE SUBSURFACE OF EAST TENNESSEE}

Factors suggesting that the Valley and Ridge province of east Tennessee should be considered as a prime target for oil and gas exploration include the following: (1) the commercial quantities of oil that have been produced from the Trenton Limestone along the west edge of the Valley and Ridge a few miles north of the Tennessee State line at Rose Hill, Va. (Miller, 1973), (2) shows of oil and gas in shallow water wells in the area, (3) oil found in vugs and in fracture porosity in roadcut exposures and isolated outcrops of the lower part of the Knox Group and in parts of the Middle and Upper Ordovician limestone sequence, (4) a thick stratigraphic section in the Valley and Ridge that shows lateral facies changes, (5) the widespread occurrence of a thick shale sequence (Conasauga Shale) that under the proper structural conditions may act as a seal, and (6) an abundance of fracture porosity.

Although many of the above factors have been evident for years, the Valley and Ridge of east Tennessee remains as one of the last almost completely untested large areas in the Eastern United States. This lack of exploration is apparently based on a rigid adherence to the carbon ratio theory, the fact that the area is a little-understood complex structural province, and, in the past, the widespread exploitation of shallow production from structurally uncomplicated reservoirs in the adjacent Appalachian Plateau. Now that development of reservoirs adjacent to the Valley and Ridge has reached a mature stage, future exploration efforts should be directed eastward toward untested areas, like

Figure 5.-Sequential development of structure. Lithologic units are: (1) basement, (2) Rome Formation and Conasauga Shale, (3) Knox Group and Chickamauga Limestone, (4) Upper Ordovician through Mississippian, and (5) Pennsylvanian. $A$, Orogenic cycle initiated with the regional development of a basal décollement. Minor local obstructions within the décollement zone cause the master plate to begin to imbricate. $B$, Continuing growth of subsurface obstruction results in the formation of the first major imbricate thrust fault. Movement of the overriding plate thrusts Valley and Ridge rocks over a projection of the Appalachian Plateau and produces a large rootless anticline by duplication of beds. Dotted lines in section $B$ through $E$ mark the general position where later imbricate thrust faults form. $C$, Continuing movement and tightening of the rootless anticline create space problems at points of maximum stress. Formation of major or minor imbricate thrust faults resolves the space problems. $D, E$, and $F$, Once imbrication begins, space problems continue to develop and are resolved by a west-toeast progression of imbrication. the Valley and Ridge, especially if the reasons for past rejection are mainly demonstrably invalid.

The carbon ratio theory, which suggests that a relationship exists between the percent of fixed carbon in coals and the distribution and abundance of oil, evolved in the early 1900's (White, 1915). White's concept suggested that few or no commercial quantities of oil would be found in areas where the fixed carbon in coal exceeded 70 percent. Fixed carbon ratios in Virginia, West Virginia, and Pennsylvania were found to increase progressively eastward, and the 70-percent isocarb nearly coincides with the western edge of the Valley and Ridge. Although coal beds do not occur in the Valley and Ridge from Pennsylvania to Alabama, the 70-percent isocarb occurring near the western edge of the Valley and Ridge in West Virginia and Pennsylvania was extrapolated southward to rule out the entire province as a target for oil exploration.

Recent studies (Epstein, Epstein, and Harris, 1974) have shown that color changes in conodonts tend to follow trends on the fixed carbon of coal beds. Thus, in areas where coal beds do not occur, color changes of conodonts can be used to measure the percent of fixed carbon. Preliminary data from east Tennessee indicate that the fixed carbon percent tends to decrease westward from about 70 percent at the Saltville fault to less than 60 percent in Plateau rocks west of the Valley and Ridge, suggesting the possibility that commercial quantities of both oil and gas may occur in parts of the Valley and Ridge of Tennessee.

The fact that the Valley and Ridge of east Tennessee is a structurally complex province, within which thrust faulting and varying degrees of folding are associated, has in the past and continues in the present to deter petroleum exploration. Although restricted to a small part of the west half of the Valley and Ridge in Tennessee, the recently released seismic data furnish fresh insight into the kinds of subsurface structural traps present and their possible distribution. Analysis of the seismic data focuses attention on a fundamental change from west to east both in the complexities of subsurface structure and the total stratigraphic section involved (fig. 2). East of the Clinchport fault, the total stratigraphic interval is limited to a sequence that includes only Cambrian to Upper Ordovician. Subsurface structure is characterized by an abundance of large fault-bound masses of Rome Formation and Conasauga Shale and by minor splay thrusting. Data concerning the lateral limits of fault-bound masses are not definitive. However, segment $B-C$ of the profile was shot at an angle to strike and individual masses are seen to persist; these facts suggest that at least some fault- 
bound masses are plates having considerable lateral extent. Where sealed by the Conasauga Shale, faultbound plates appear to be structurally situated so that fracture-porosity zones within the Rome part of these plates may have acted as traps for hydrocarbons migrating updip.

West of the Clinchport fault, the subsurface includes a sequence of Cambrian through Mississippian strata buried beneath a thrust sheet containing Cambrian to Upper Orlovician rocks. Reconstruction of the development of structure in the area (fig. 5) indicates that the Cambrian through Mississippian sequence is a subsurface projection of the Appalachian Plateau buried beneath the Chattanooga and associated faults of the Valley and Ridge. Because the Chattanooga fault is a continuous structural element from the Jacksboro fault to the southern border of Tennessee, it seems reasonable to suggest that a Cambrian through Mississippian projection of the Appalachian Plateau may be present in the subsurface beneath the entire length of the Chattanooga thrust sheet and perhaps beneath part of the associated Kingston thrust sheet. Thus, a nearly complete buried Paleozoic section about $4 \mathrm{mi}(6.5 \mathrm{~km})$ wide and $100 \mathrm{mi}(160 \mathrm{~km})$ long may exist in the subsurface at the edge of the Valley and Ridge. As delineated by the seismic data (fig. 2), subsurface structure within the Appalachian Plateau projection is dominated by the occurrence of a large splay anticline produced by imbricate thrusting. The indication that splay anticlines occur in the subsurface is important for the following reasons: (1) splay anticlines on a worldwide basis have been found to be prime fractureporosity traps, (2) this structure affords a favorable setting in which to test an almost complete Paleozoic section, and (3) similar kinds of structures associated with thin-skinned tectonics have produced quantities of gas, both along the west edge of the Valley and Ridge and in the adjacent plateau in Pennsylvania, Maryland, and West Virginia (Gwinn, 1964; Jacobeen and Kanes, 1974). There seems to be little doubt that the Appalachian Plateau projection beneath the Valley and Ridge of east Tennessee deserves careful consideration in any future oil and gas exploration program.

\section{REFERENCES CITED}

Butts, Charles, 1927, Fensters in the Cumberland overthrust block in southwestern Virginia: Virginia Geol. Survey Bull. 28, 12 p.

deSitter, L. U., 1956, Structural geology : New York, McGrawHill Book Co., 552 p.

Epstein, A. G., Epstein, J. B., and Harris, L. D., 1974, Incipient metamorphism, structural anomalies, and oil and gas potential in the Appalachian Basin determined from conodont color: Geol. Soc. America Abs. with Programs, v. 6, no. 7, p. 723-724.

Gwinn, V. E., 1964, Thin-skinned tectonics in the Plateau and northwestern Valley and Ridge provinces of the Central Appalachians: Geol. Soc. America Bull., v. 75, no. 9, p. 863-900.

Harris, L. D., 1970, Details of thin-skinned tectonics in parts of the Valley and Ridge and Cumberland Plateau provinces of the Southern Appalachians, chap. 10 in Fisher, G. W., Pettijohn, F. J., Reed, J. C., Jr., and Weaver, K. N., eds., Studies of Appalachian geology - central and southern : New York, Interscience Publishers, p. 161-173.

Jacobeen, Frank, Jr., and Kanes, W. H., 1974, Structure of Broadtop Synclinorium and its implications for Appalachian structural style: Am. Assoc. Petroleum Geologists Bull., v. 58, no. 3, p. 362-375.

Milici, R. C., 1975, Structural patterns in the Southern Appalachians-evidence for a gravity slide mechanism for Alleghenian deformation: Geol. Soc. American Bull., v. 86 , no. 9, p. 1316-1320.

Miller, R. L., 1973, Structural setting of hydrocarbon accumulations in folded southern Appalachians: Am. Assoc. Petroleum Geologists Bull., v. 57, no. 12, p. 2419-2427.

Miller, R. L., and Fuller, J. O., 1.954, Geology and oil resources of the Rose Hill district-the fenster area of the Cumberland overthrust block-Lee County, Virginia: Virginia Geol. Survey Bull. 71, 383 p.

Rich, J. L., 1934, Mechanics of low-angle overthrust faulting as illustrated by Cumberland thrust block, Vìrginia, Kentucky, and Tennessee: Am. Assoc. Petroleum Geologists Bull., v. 18, no. 12, p. 1584-1596.

Rodgers, John, 1949, Evolution of thought on structure of middle and southern Appalachians: Am. Assoc. Petroleum Geologists Bull., v. 33, no. 10, p. 1643-1654.

- 1970, The tectonics of the Appalachians: New York, Interscience Publishers, $271 \mathrm{p}$.

Wentworth, C. K., 1921, Russell Fork fault, in The geology and coal resources of Dickenson County, Virginia: Virginia Geol. Survey Bull. 21, p. 53-67.

White, C. D., 1915, Some relations in origin between coal and petroleum: Washington Acad. Sci. Jour., v. 5, p. 189-212. 


\title{
HIGH-LEVEL PLATEAUS OF THE SOUTHEASTERN BEARTOOTH MOUNTAINS, MONTANA AND WYOMING- REMNANTS OF AN EXHUMED SUB-CAMBRIAN MARINE PLAIN
}

\author{
By FRANK S. SIMONS and THEODORE J. ARMBRUSTMACHER, \\ Denver, Colo.
}

\begin{abstract}
The Beartooth Mountains of south-central Montana and northwestern Wyoming are a northwesterly trending high rugged range made up mainly of Precambrian metamorphic rocks. The southeastern part of the range is characterized by extensive high-altitude flat or gently rolling plateaus separated by deep glaciated canyons. The plateaus along the crest of the range are at altitudes of more than 3,350 metres $(11,000 \mathrm{ft})$, whereas those on the flanks of the range are much lower. They are almost entirely on Precambrian rocks, and only small patches of Cambrian sedimentary rocks still remain at a few places in the high mountains. Topographic profles across the southeastern Beartooth Mountains show that: (1) plateaus bearing the sedimentary remnants lie very close to the position of the sub-Cambrian depositional surface as projected from known occurrences of that surface along the south side of the mountains; (2) other plateaus on the crest and southwest flank also lie near this projected position; and (3) high plateaus and other summits on the northeast slope in areas distant from known or projected positions of the sub-Cambrian surface are markedly accordant. We believe the plateaus along the crest and southwest flank of the range to be remnants of an exhumed marine plain of Early Cambrian or Precambrian age, and those on the northeast flank may possibly have a similar origin. The sub-Cambrian depositional surface was protected until early Tertiary time by a cover of Paleozoic sedimentary rocks, and parts of it probably were covered until Pliocene time by Eocene volcanic rocks. The surface subsequently has been profoundly modified by fluvial and glacial erosion and by mass wasting.
\end{abstract}

A study of the mineral potential of the Beartooth Primitive Area and vicinity in Montana and Wyoming (Simons and others, 1973) afforded an opportunity to reconnoiter geologically nearly all the southeastern half of the Beartooth Mountains. In this report we present some observations made during the mineral survey that bear on the origin of the conspicuous highlevel plateaus in that part of the Beartooth Mountains.

The nature and origin of the Beartooth plateaus have been a subject of interest to many workers. Bevan (1923) proposed that the plateaus are parts of two dissected surfaces, a summit plateau at altitudes of $3,600-3,800$ metres $(12,000-12,400 \mathrm{ft})$ and a subsummit plateau $450-600 \mathrm{~m}(1,500-2,000 \mathrm{ft})$ lower. Remnants of Bevan's summit platean include the ridges of Granite Peak and Sawtooth Mountain as well as, presumably (although he does not mention them by name), such flat-topped peaks as Summit, Snowbank, Castle Rock, Castle, and Beartooth Mountains and Beartooth Plateau. His subsummit plateau comprises most of the extensive plateaus such as East Boulder, Silver Run, and Hellroaring. Bevan argued against the likelihood of either surface being an exhumed sub-Cambrian erosional surface, and he concluded that both surfaces are remnants of peneplains, the summit peneplain of Oligocene age and the subsummit probably of Pliocene age. Hughes (1933) interpreted the subsummit peneplain of Bevan in the southeastem part of the Beartooth Mountains as an exhumed marine plain and believed that the summit peneplain also may be part of the same plain. He based his argument mainly on the presence of a large outlier of Cambrian sedimentary rocks on Dillworth Bench in the southeast corner of the Beartooth Mountains (Pierce, 1965). Thom, Jones, and Chamberlin (1935) also believed that the summit peneplain is part of a sub-Cambrian wavecut surface and, furthermore, that this surface could be contoured to give a measure of post-Cambrian deformation. Sharp (1938) argued that, except for a few small resurrected areas, all the Beartooth plateaus are part of a continuous upland surface that is not a peneplain but, rather, has resulted from erosional modification of an elongate uplifted mountain mass.

The Beartooth Mountains are a large and rugged mountain range in south-central Montana and northwestern Wyoming just northeast of Yellowstone National Park; a small part of the mountains lies within the park (fig. 1). The Beartooth Mountains are about 120 kilometres $(75 \mathrm{mi})$ long in a northwesterly direc- 


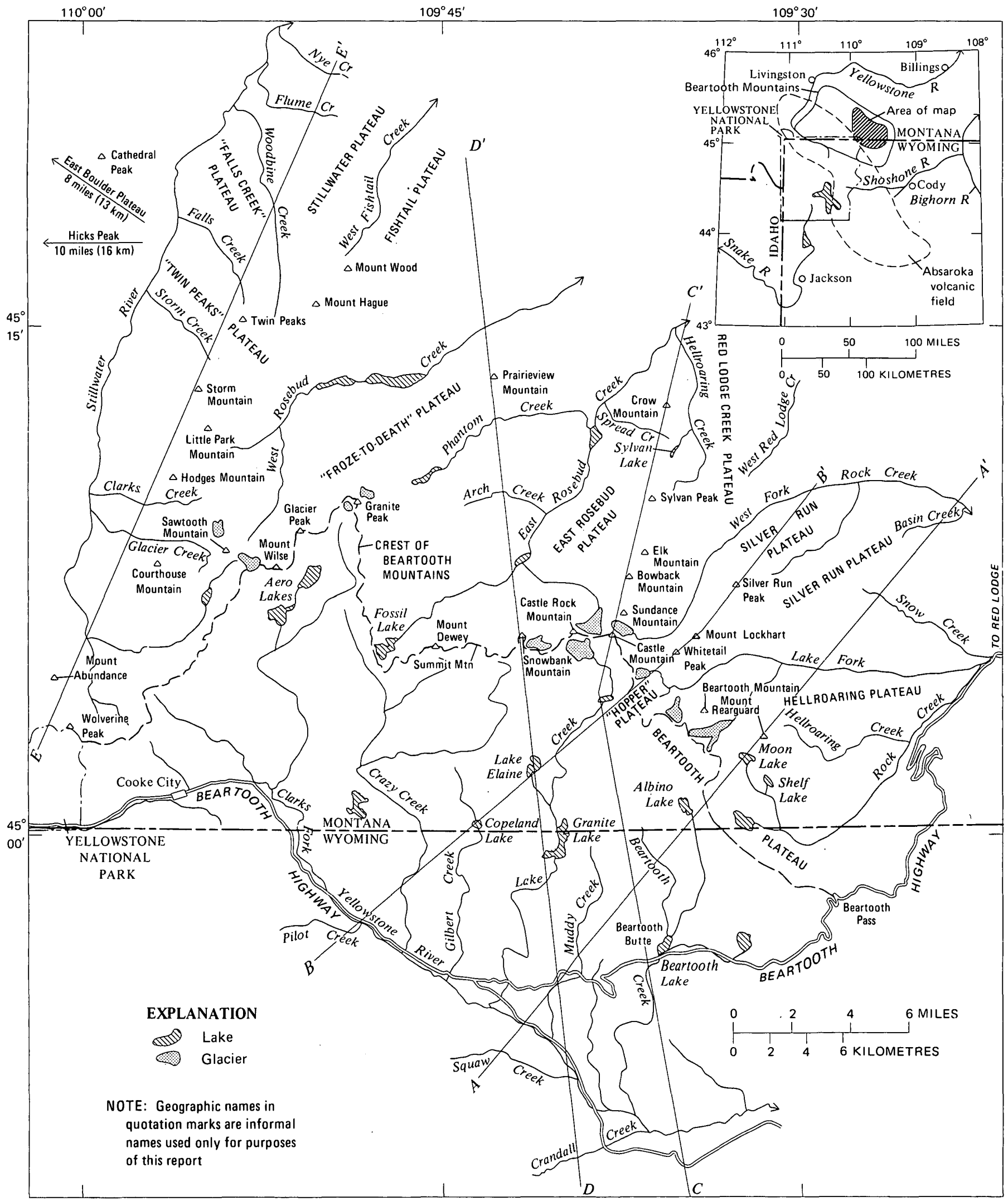

Figure 1.-Map of the southeastern part of the Beartooth Mountains, Montana and Wyoming, showing location of principal geographic features and topographic profiles (fig. 8). 
tion and 40-65 km (25-40 mi) wide, and are entirely within the drainage system of the Yellowstone River. The adjoining terrain along most of the mountain perimeter is at an average altitude of about $1,500 \mathrm{~m}$ $(5,000 \mathrm{ft})$, and the mountains rise steeply $1,200-1,500$ $\mathrm{m}(4,000-5,000 \mathrm{ft})$ higher; the southwest side of the mountains is less clearly defined topographically. The lowest altitude in the Beartooth Mountains is $1,350 \mathrm{~m}$ $(4,400 \mathrm{ft})$ at the mouth of the canyon of the Clarks Fork of the Yellowstone, and the highest point in the range, and also in Montana, is Granite Peak (3,900 m; $12,799 \mathrm{ft})$.

The Beartooth Mountains are essentially a block of Precambrian metamorphic rocks-granitic gneiss and some amphibolite-intruded by many Precambrian mafic dikes. Along the southwest border of the mountains and over a large area in the western part, the Precambrian rocks are overlain by Paleozoic sedimentary rocks and Tertiary volcanic rocks (Foose and others, 1961). In about two-thirds of the mountain area, however, the bedrock is of Precambrian age.
The east, northeast, and northwest sides of the Beartooth block, and part of the southwest side as well, are defined by steeply inclined faults along which the block was uplifted $4,500-6,000 \mathrm{~m}(15,000-20,000 \mathrm{ft})$ above the adjoining basins in Late Cretaceous and early Tertiary time (Foose and others, 1961, p. 1148-1149; Pierce, 1965). Subsequent regional uplift in late Tertiary time was followed by profound fluvial and glacial erosion that has produced the present rugged topography of deep, steep-walled canyons, jagged peaks and divides, and extensive high plateaus.

The crest of the southeastern Beartooth Mountains is very sinuous but in a general way trends northwest about $32 \mathrm{~km}(20 \mathrm{mi})$ from Beartooth Pass on the Beartooth Highway to Granite Peak and thence southwest about $19 \mathrm{~km}$ (12 mi) to Wolverine Peak (see fig. 13 for geography). Most of the crest is more than $3,000 \mathrm{~m}$ $(10,000 \mathrm{ft})$ in altitude, and that part between Beartooth Pass and Mount Dewey is mostly above 3,350 m $(11,000 \mathrm{ft})$. Along most of the crest the southwest slope is moderate and the northeast slope very steep, but at

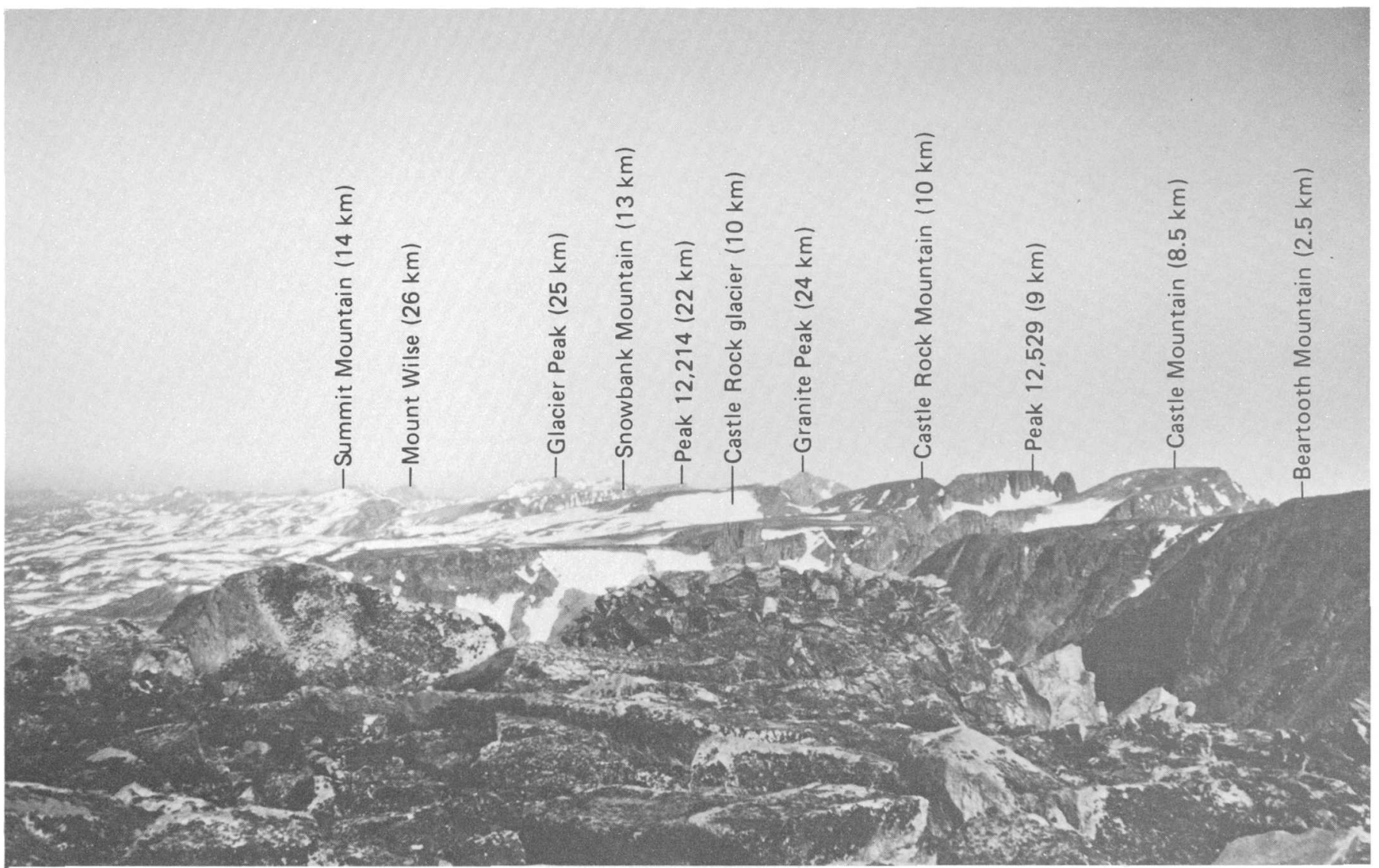

Figure 2.-Beartooth crest and southwest flank of Beartooth Mountains, looking northwestward from an altitude of 3,730 $\mathrm{m}$ $(12,250 \mathrm{ft})$ on Beartooth Plateau $1.6 \mathrm{~km}$ (1 mi) northwest of outlet of Moon Lake. Dissected surface of Beartooth Plateau, in foreground, slopes gently to the southwest (left). Distances, from the point of observation, to some flat-topped remnants of the plateau are given. 
many places the crest is marked by small plateaus that slope gently southwest or south (fig. 2). The summits of Castle Mountain $(3,840 \mathrm{~m} ; 12,600 \mathrm{ft})$ and Castle Rock Mountain $(3,780 \mathrm{~m} ; 12,400 \mathrm{ft})$, each of about 4 hectares (10 acres) in extent, and a smaller summit between the two at an altitude of $3,810 \mathrm{~m}(12,500 \mathrm{ft})$ are the highest plateaus in the Beartooth Mountains.

North of the Beartooth crest the topography is dominated by broad plateaus surmounted by jagged peaks and separated by widely spaced deep and steep-walled canyons, many of which head in ice- or snow-filled cirques. Plateaus are almost everywhere above $3,000 \mathrm{~m}$ $(10,000 \mathrm{ft})$. Surfaces of extensive plateaus are typically rolling (figs. $3 A, 3 B$ ) and some small plateaus, such as Beartooth Mountain in figure $3 C$, are remarkably planar. Plateau surfaces are largely mantled by felsenmeer-angular blocks and slabs of frost-riven rockand undisturbed rock outcrops are sparse except around plateau margins. Some felsenmeer has enough soil on it to support alpine turf or even small shrubs or trees (fig. $4 A$ ), but much of it is simply a rough rocky expanse of jagged blocks almost devoid of soil or vegetation (fig. $4 B$ ).

Most of the plateaus on the north flank of the mountains appear to have been unglaciated during the later glaciations, as indicated by the presence on them of tors (fig. 5) which would have been eroded away if a thick icecap had been present. Nevertheless, valley glaciers extended far down main canyons at that time, and sparse giacial erratics attest to the presence of a recent icecap on a few plateau surfaces between Rock and Hellroaring Creeks in the southeastern part of the

Frgure 3.-Plateau surfaces. Distances,from the point of observation, to some conspicuous topographic features are given. $A$, View looking southeastward across the northeast flank of the Beartooth Mountains from plateau surface (foreground), altitude $3,200 \mathrm{~m}(10,500 \mathrm{ft})$, near Cathedral Peak. High peaks are Mount Wood $(3,860 \mathrm{~m} ; 12,661 \mathrm{ft})$ and Mount Hague $(3,760 \mathrm{~m} ; 12,328 \mathrm{ft})$. Note the rolling surfaces of the various plateaus. $B$, Divide between Spread and Hellroaring Creeks on northeast flank of Beartooth Mountains, looking south-southeast from swale, altitude about 2,900 m $(9,400$ $\mathrm{ft}), 1 \mathrm{~km}(0.6 \mathrm{mi})$ south of Crow Mountain. East Rosebud Plateau and cliffs of Sylvan Lake cirque in right background.

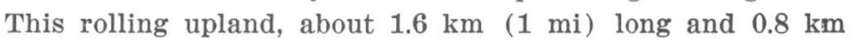
(0.5 mi) wide, may be a northerly outlier of the larger East Rosebud Plateau (fig. 8, $C-C^{\prime}$ ). To west (right), Spread Creek drops precipitously $900 \mathrm{~m}(3,000 \mathrm{ft})$ to East Rosebud Creek. $C$, Beartooth crest and northeast flank of Beartooth Mountains, looking north-northwest from an altitude of $3,270 \mathrm{~m}(12,250 \mathrm{ft})$ on Beartooth Plateau $1.6 \mathrm{~km}$ (1 mi) northwest of outlet of Moon Lake. Flattish summit of Beartooth Mountain, about 20 hectares (50 acres) in extent, slopes gently southwestward at about $140 \mathrm{~m} / \mathrm{km} \quad(700$ $\mathrm{ft} / \mathrm{mi})$. mountains. Large erratics rest on Hellroaring Plateau southeast of Shelf Lake (fig. 6A), and at several places on the plateaus south of Hellroaring Creek at altitudes of $3,000-3,100 \mathrm{~m}$ (9,900-10,200 ft). Moreover, glacial till covers a very flat area of about $8 \mathrm{~km}^{2}(3$ $\mathrm{mi}^{2}$ ) on the south end of East Boulder Plateau at an altitude of $2,860-2,750 \mathrm{~m} \mathrm{(9,400-9,000} \mathrm{ft)} \mathrm{(fig.} \mathrm{6B);}$ this plateau is about $8 \mathrm{~km}$ ( $5 \mathrm{mi}$ ) west of the northwest corner of the area shown in figure 1.
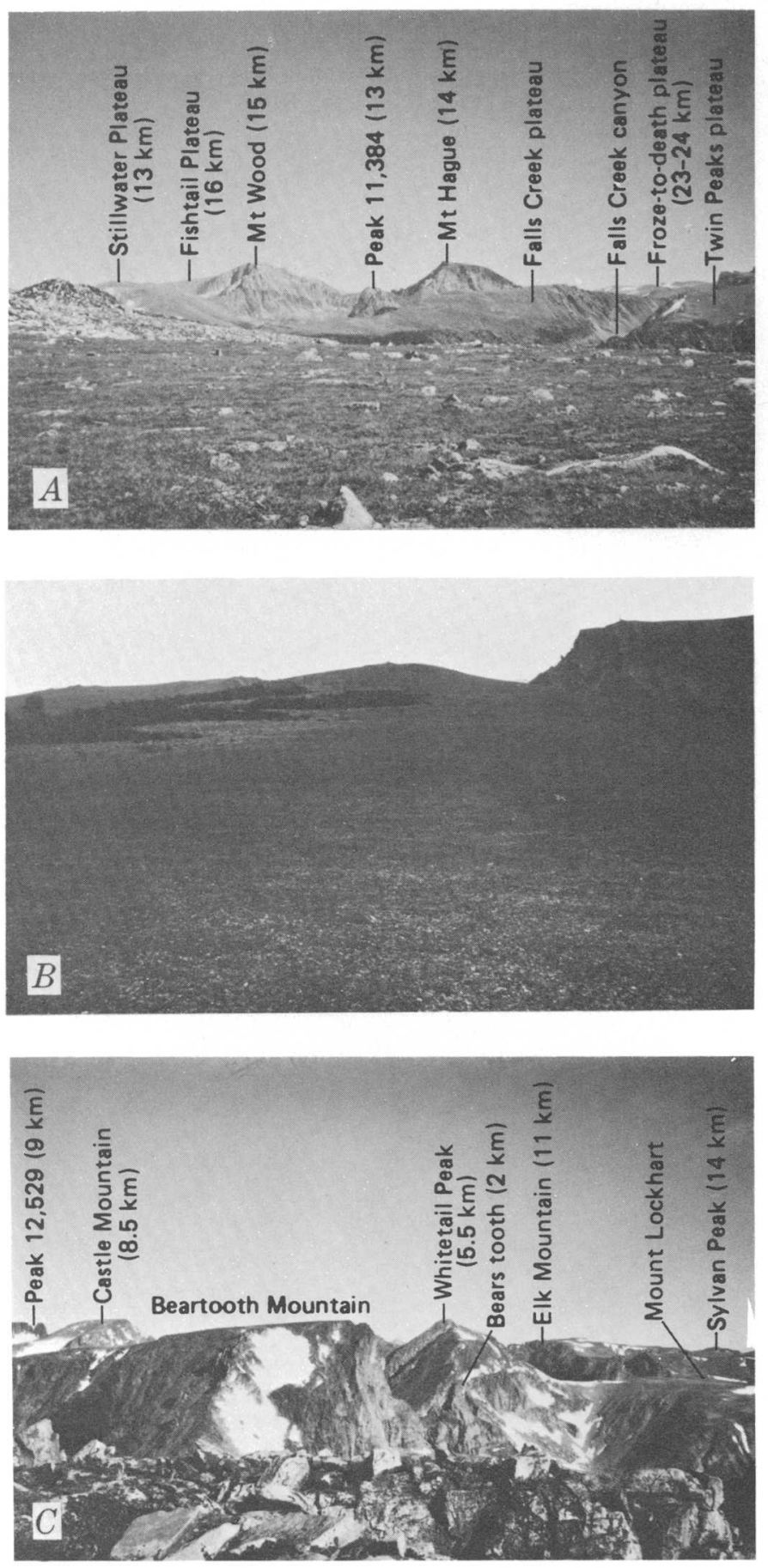

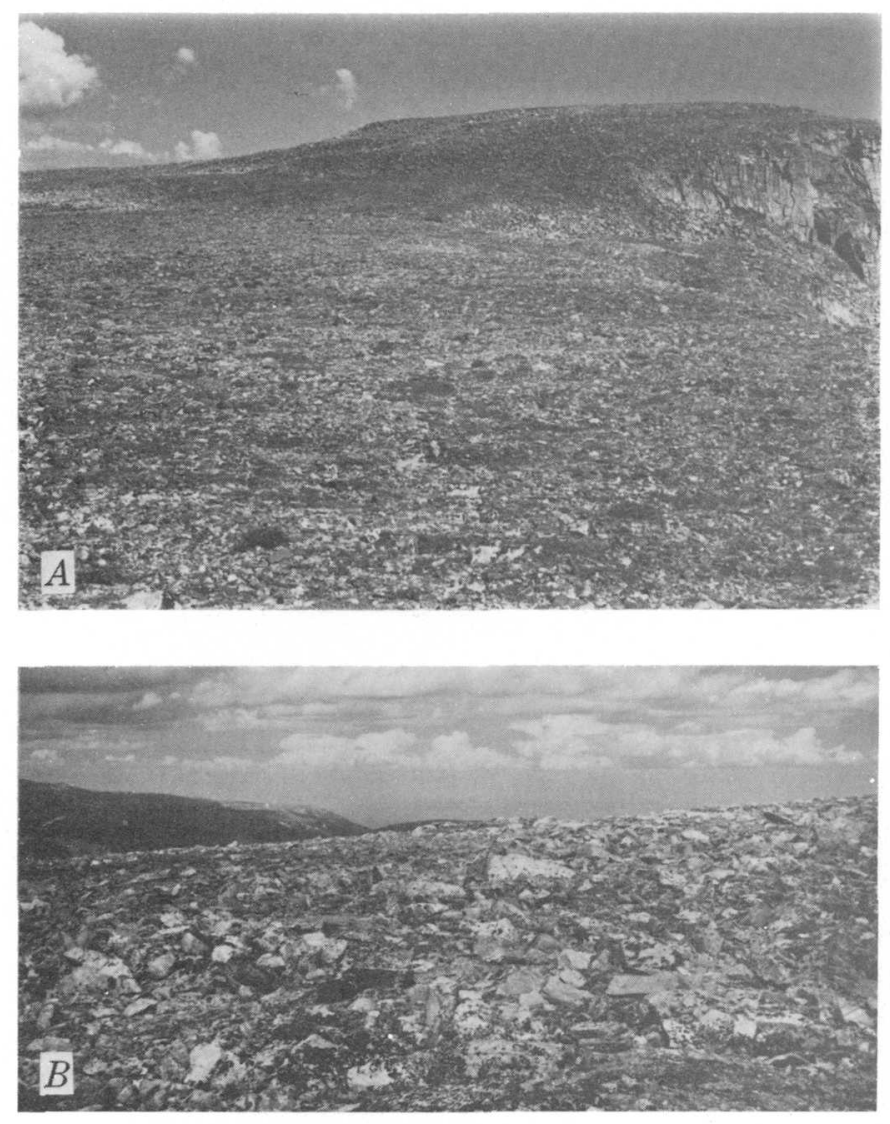

Figure 4.-Plateau surfaces mantled by felsenmeer. A, Plateau, altitude $3,050-3,100 \mathrm{~m}$ (10,000-10,150 ft), east of Hicks Peak $(17.5 \mathrm{~km}$ or $11 \mathrm{mi}$ west of the Stillwater River). Rock fragments are relatively small, mostly less than $30 \mathrm{~cm}$ ( $1 \mathrm{ft}$ ) across, and enough soil has developed to support abundant low-growing shrubs and other tundra vegetation. $B$, Plateau, altitude about $3,500 \mathrm{~m}(11,600 \mathrm{ft})$, on northwest flank of Beartooth Mountains $3 \mathrm{~km}$ (2 mi) west of Bowback Mountain. Only very sparse soil has developed on this expanse of frost-riven rock fragments, most of which are more than $30 \mathrm{~cm}(1 \mathrm{ft})$ across.

South of the Beartooth crest the mountains are much less dissected and their topography is mainly a rolling rock surface of generally moderate relief that slopes gently southwestward (fig. 2). The most prominent feature on the south flank is Beartooth Butte, a large isolated mass of Paleozoic sedimentary rock that rises $300-600 \mathrm{~m}(1,000-2,000 \mathrm{ft})$ above its surroundings just north of the Beartooth Highway (fig. 7). Extensive rounded, smoothed, and striated outcrops, a closely spaced network of small streams, and countless rock basin lakes and swamps, particularly in the area between Aero and Albino Lakes, all attest to the former presence of an icecap (fig. $6 C$ ).

The ideas of earlier workers on the nature of the Beartooth plateaus, summarized previously, were based on limited field observations and evolved without bene-

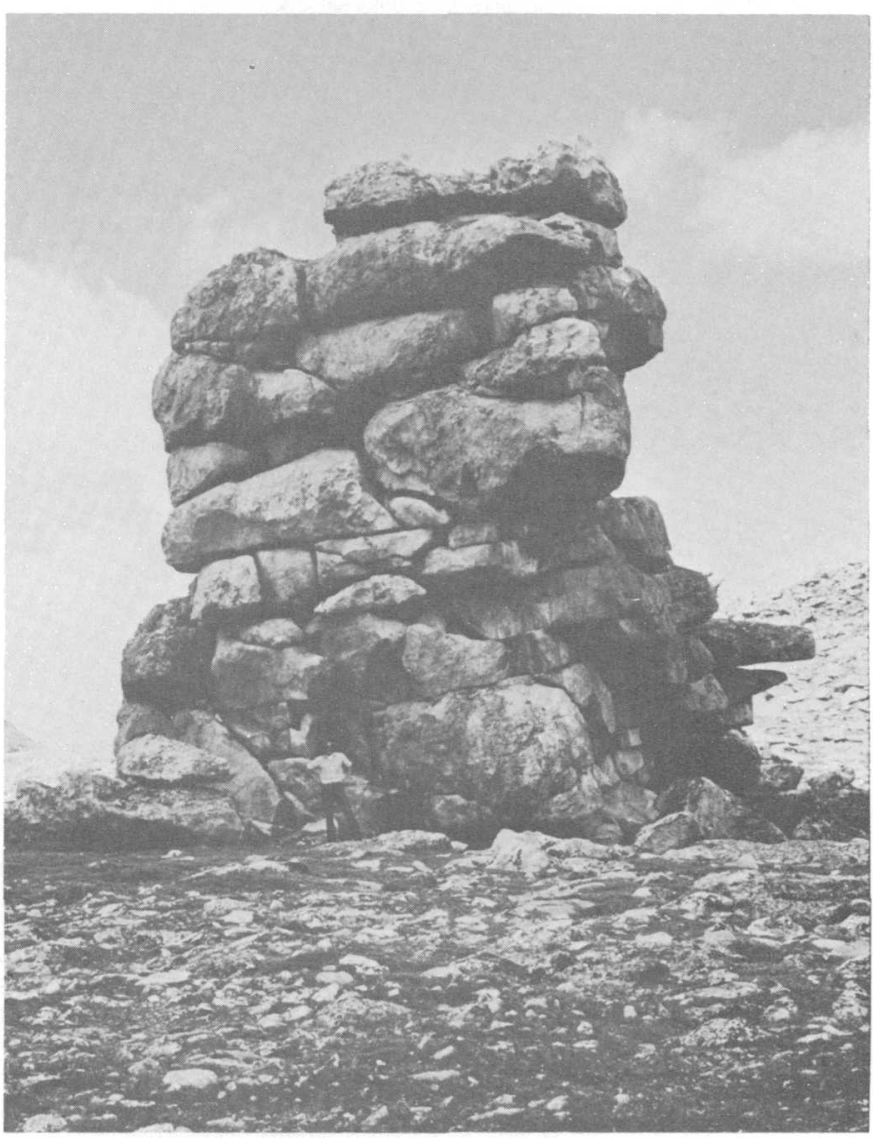

Figure 5.-Tor near south edge of Silver Run Plateau, 7.5 $\mathrm{km}(4.7 \mathrm{mi})$ east of Whitetail Peak, at an altitude of 3,320 $\mathrm{m}(10,200 \mathrm{ft})$. The tor is about $12 \mathrm{~m}(40 \mathrm{ft})$ high and consists of gneiss that has steeply dipping foliation. Weathering has etched out subhorizontal joints and rounded off the resulting slabs, especially near the top of the tor. The presence of this tor, as well as other less spectacular ones, indicates that no extensive ice sheet has moved over Silver Run Plateau (and by inference most other plateaus on the northeast flank of the Beartooth Mountains) during the recent past.

fit of detailed maps. The entire area is now covered by modern topographic maps, and geologic maps of the Beartooth Butte and Deep Lake quadrangles have been published (Pierce and Nelson, 1971; Pierce, 1965). In addition, Larsen, Poldervaart, and Kirchmayer (1966, pl. 1) reported an outcrop of Cambrian Flathead Sandstone on Beartooth Plateau east of Albino Lake, and we found other Flathead remnants farther north on the same plateau, and so more data are now available as aids in interpreting the Beartooth plateaus. In order to utilize these data, about a dozen topographic profiles were drawn across the Beartooth Mountains, five of which are shown on figure 8 ; four are across the southeastern part of the range, and the fifth is across the center for comparison. 

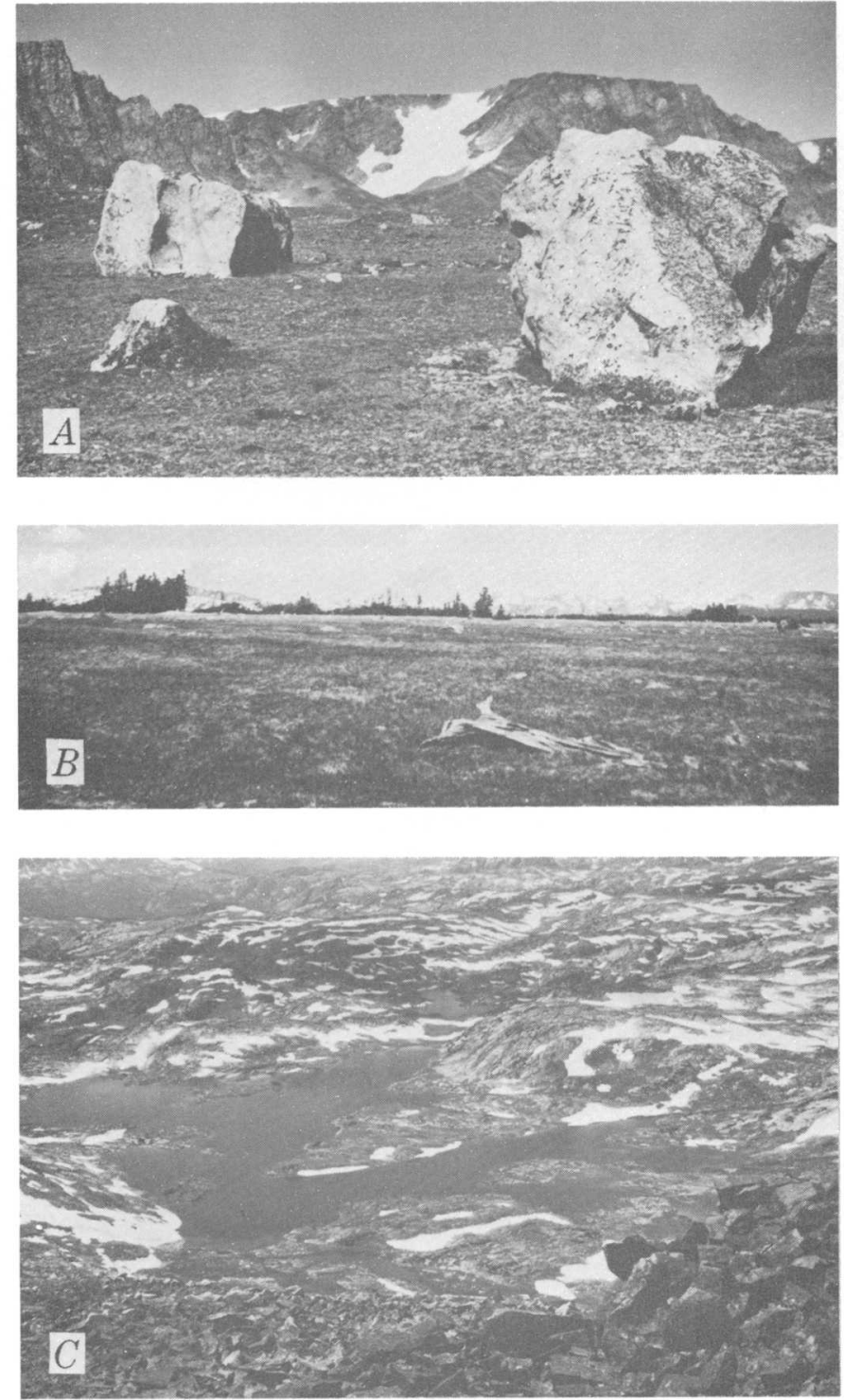

Figure 6.-Glacial features on plateaus. A, Glacial erratics at an altitude of about $3,230 \mathrm{~m}(10,600 \mathrm{ft})$ on south lobe of Hellroaring Plateau $0.8 \mathrm{~km}(0.5 \mathrm{mi})$ southeast of outlet of Shelf Lake; looking northwest, Beartooth Plateau is in background. Erratics are of gray coarse granitic gneiss, resting on frost-riven pink gneiss and metadolerite. Boulder at right is about $3 \mathrm{~m}(10 \mathrm{ft})$ across and $6 \mathrm{~m}(20 \mathrm{ft})$ long. $B$, Glacial till-covered surface, extreme south end of East Boulder Plateau, altitude about $2,860 \mathrm{~m}(9,400 \mathrm{ft})$. A few large boulders protrude above the remarkably flat and even surface; Bevan (1945) reported that some of these boulders are soled and striated. $C$, Fossil Lake (alt 3,015 m; 9,900 ft), looking west from Mount Dewey. The lake lies just east of a broad pass on the Beartooth crest in an area of hummocky topography that indicates the former presence of an icecap.

Certain inferences may be drawn from the profiles as follows:

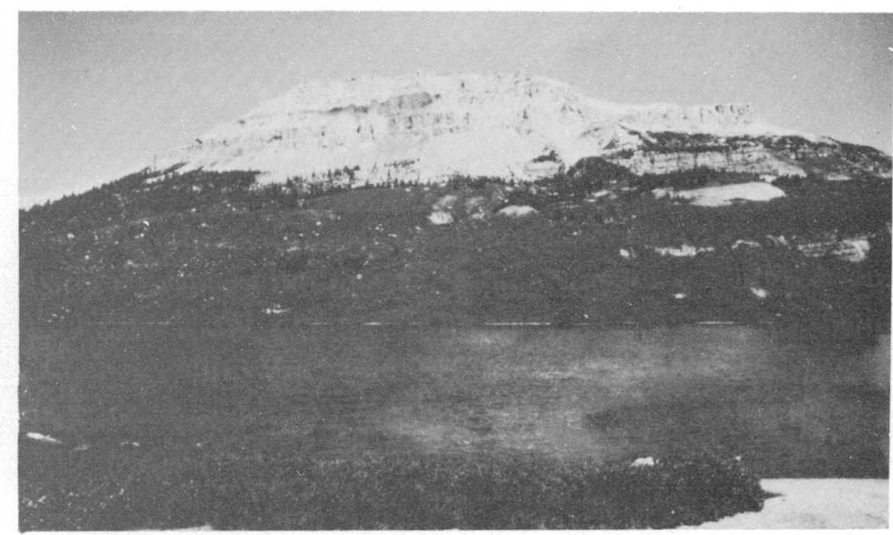

Figure 7.-Beartooth Butte, Beartooth Lake in foreground, looking northwest. The butte rises $500 \mathrm{~m} \mathrm{(1,600} \mathrm{ft)} \mathrm{above}$ the lake. It is made up of Paleozoic sedimentary rocks ranging in age from Cambrian to Devonian that dip gently south and rest unconformably on Precambrian metamorphic rocks.

1. Between the southern limit of outcrop of Precambrian rocks and the crest of the range (profiles $A-A^{\prime}$ to $\left.D-D^{\prime}\right)$ the plateau surfaces on the Precambrian rocks appear to be remnants of an erosionally modified sub-Cambrian plain. Evidence for this inference is remnants of Flathead Sandstone on Beartooth Plateau $\left(A-A^{\prime}\right)$ and on Hopper plateau (just off the line of $B-B^{\prime}$ ). Evidence provided by profiles $C-C^{\prime}$ and $D-D^{\prime}$ is only permissive; the northward projection of the base of the Paleozoic rocks lies very close to the reconstructed sub-Cambrian surface. In profile $C-C^{\prime}$, the base of the Paleozoic rocks of Beartooth Butte projects almost exactly to the large flat area atop Sundance Mountain (the higher part of Castle Mountain would thus have been a monadnock on the sub-Cambrian surface), whereas on profile $D-D^{\prime}$, the base of the Paleozoic rocks projects slightly above Snowbank Mountain.

2. Between the crest of the range and the north ends of profiles $A-A^{\prime}$ to $D-D^{\prime}$, the various plateaus can be connected along a reasonably smooth curve, and therefore they could be remnants of the same sub-Cambrian surface, relatively downwarped or downfaulted between the range crest and the northeast range front; however, no direct evidence for this interpretation was found.

3. Profile $E-E^{\prime}$, drawn across a highly dissected part of the range, shows a striking accordance of summits, most of which have only small flat areas, but it does not provide any unequivocal evidence of the age of the surface apparently defined by these accordant summits. If this surface is, in whole or in part, a sub-Cambrian erosion surface, it ap- 
pears to have been displaced locally on an unrecognized fault or faults in the upper Stillwater River valley, as its projection southward from Courthouse Mountain lies well above the base of the Paleozoic rocks beneath Mount Abundance.

If the Beartooth plateaus are remnants of a subCambrian depositional surface, then their preservation, particularly in the highest parts of the mountains, through a long span of time during which the mountains were being uplifted, deeply eroded, glaciated, and weathered, is remarkable indeed. At the time uplift of the Beartooth Mountains began in Late Cretaceous time, the Precambrian rocks were overlain by perhaps $3,000 \mathrm{~m}(10,000 \mathrm{ft})$ of Paleozoic and Mesozoic sedimentary rocks, yet uplift and erosion were sufficiently rapid that by Paleocene time Precambrian rocks were exposed and by Eocene time large amounts of Precambrian detritus was being incorporated into the Wasatch Formation northeast of the present mountain front (Stow, 1938, p. 756-757; Foose and others, 1961, p. 1148, 1164). Some of the southeastern Beartooth Mountains may have been covered by andesitic volcanic rocks of the Eocene Absaroka Volcanic Supergroup (Smedes and Prostka, 1972). In particular, the abrupt erosional northeast edge of the Aibsaroka volcanic field and the great thickness-several thousand feet-of the volcanics along this edge suggest that at least part of the southwest flank of the range was covered by volcanics; however, these rocks do not now occur in the area under consideration and the only evidence of their possible former existence is a few small dikes that may have been feeders. On the other hand, volcanic rocks probably covered little or none of the northeast flank; although volcanic debris derived from the Absaroka volcanic field was reported by Stow (1938, p. 751) from the contemporaneous Wasatch Formation in one area near the east front of the Beartooth Mountains, the Wasatch elsewhere north and east of the front appears to be devoid of volcanic material (Stow, 1938, p. 757; Smedes and Prostka, 1972, p. C1), and Rouse (1937, p. $1260)$ believed that the volcanics never extended northeast of the crest of the Beartooth Mountains in the vicinity of the Montana-Wyoming State line. As noted above, Precambrian rocks were extensively exposed on the northeast flank by Eocene time.

Evidence from Yellowstone National Park and adjoining areas indicates that little erosion took place in the region from late Eocene to Pliocene time and that a rolling plateau may have extended across the Beartooth Mountains during that interval (H. J. Prostka, written commun., 1975). In the southeastern Beartooth Mountains, this plateau probably was underlain main- ly by Tertiary volcanic rocks in the area of the present southwest flank and mainly by Precambrian rocks on the northeast flank. Regional uplift in Pliocene time brought about renewed vigorous fluvial erosion that further stripped and dissected the sub-Cambrian surface, and subsequent glacial and fluvial erosion produced the present topography. This interpretation of Cenozoic geologic history implies that the sub-Cambrian surface has been exposed much longer, locally perhaps as much as $30-40 \mathrm{~m}$.y. longer, on the northeast flank of the Beartooth Mountains than on the southwest flank. This longer time of exposure may explain why the sub-Cambrian surface appears to be more modified by erosion on the northeast flank of the mountains than on the southwest flank; plateau remnants are more rounded, and accordance of summits is poorer.

Because of erosion and mass wasting in Cenozoic time, the original surface on which the Flathead Sandstone was deposited probably is nowhere preserved except in the immediate vicinity of certain outcrops of the sandstone. The surface truncates faults of probable early Tertiary age that involve Flathead Sandstone (Pierce and Nelson, 1971), and it also cuts across dikes of probable Late Cretaceous or early Tertiary age; both these features indicate that the present surface is at least in part a product of Cenozoic erosion. Some plateaus undoubtedly have been lowered by mass wasting; for instance, the extensive plateau on which the tor shown in figure 5 stands must have been lowered at least $12 \mathrm{~m}(40 \mathrm{ft})$, the height of the tor. Nevertheless, the close accordance of present-day plateaus with the projected position of the sub-Cambrian surface, as well as the occurrence on a few of them of patches of Cambrian sedimentary rocks, indicate that the sub-Cambrian surface either is preserved in, or is closely reflected by, many of these plateaus.

To summarize, we believe that, at least for the area on the crest and southwest flank of the southeastern Beartooth Mountains, our data support the contention of Hughes (1933) and Thom, Jones, and Chamberlin (1935) that the present surface on the Precambrian rocks is a stripped or exhumed sub-Cambrian plain, substantially modified by glacial and fluvial erosion and by mass wasting. The high, flat remnants of this plain, such as Snowbank, Castle Rock, and Sundance Mountains, Hopper plateau, and Beartooth Plateau, have been protected until Tertiary time by a cover of Paleozoic sedimentary rocks and Eocene volcanics, now almost entirely removed. The plateaus northeast of the crest may also be modified remnants of the same plain, but we have no direct evidence that they are. 

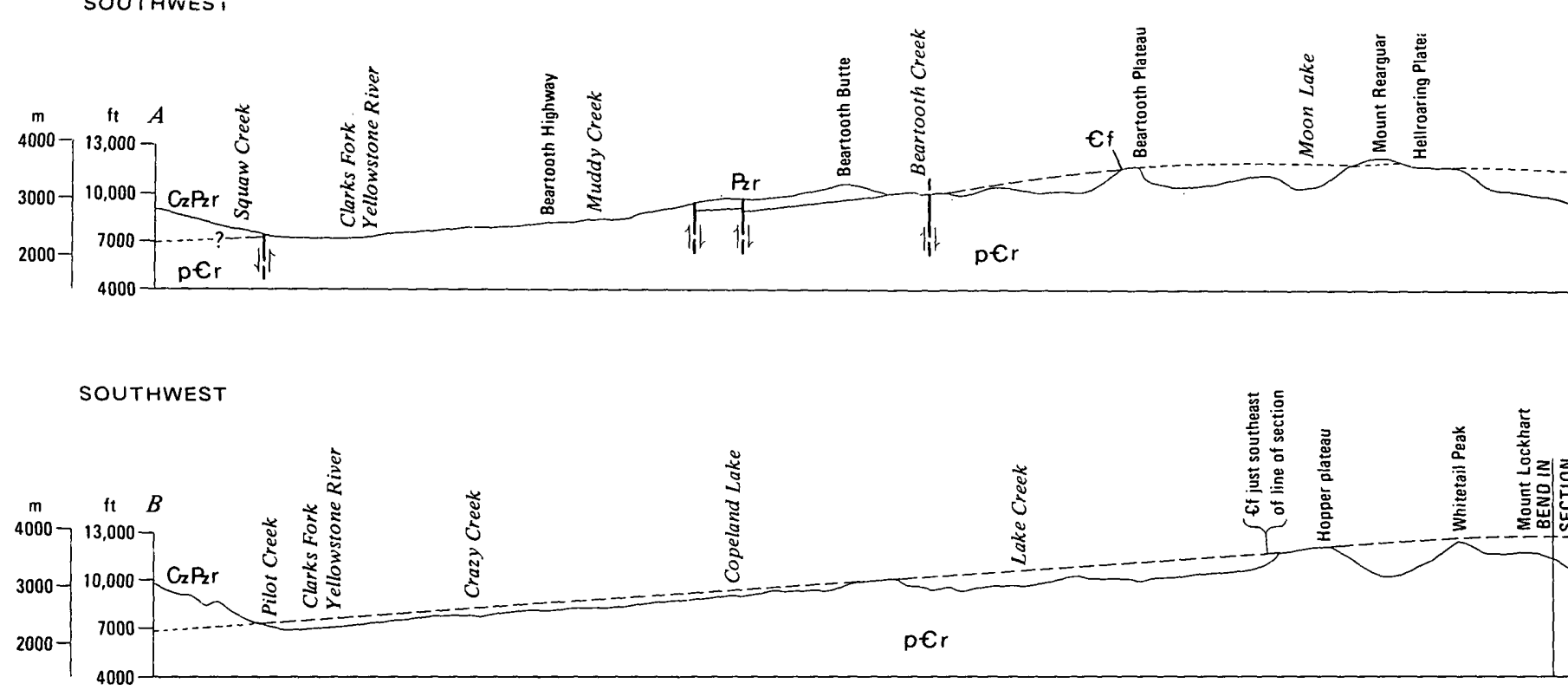

\section{EAST SOUTHEAST}

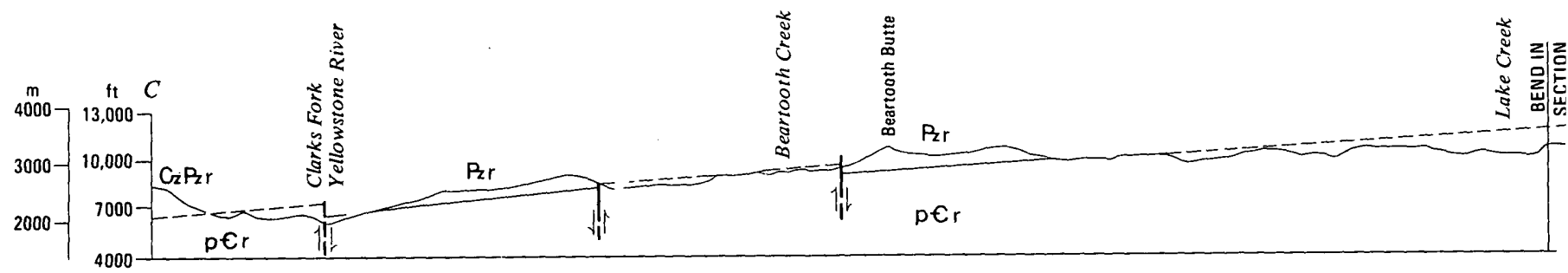

SOUTH SOUTHEAST
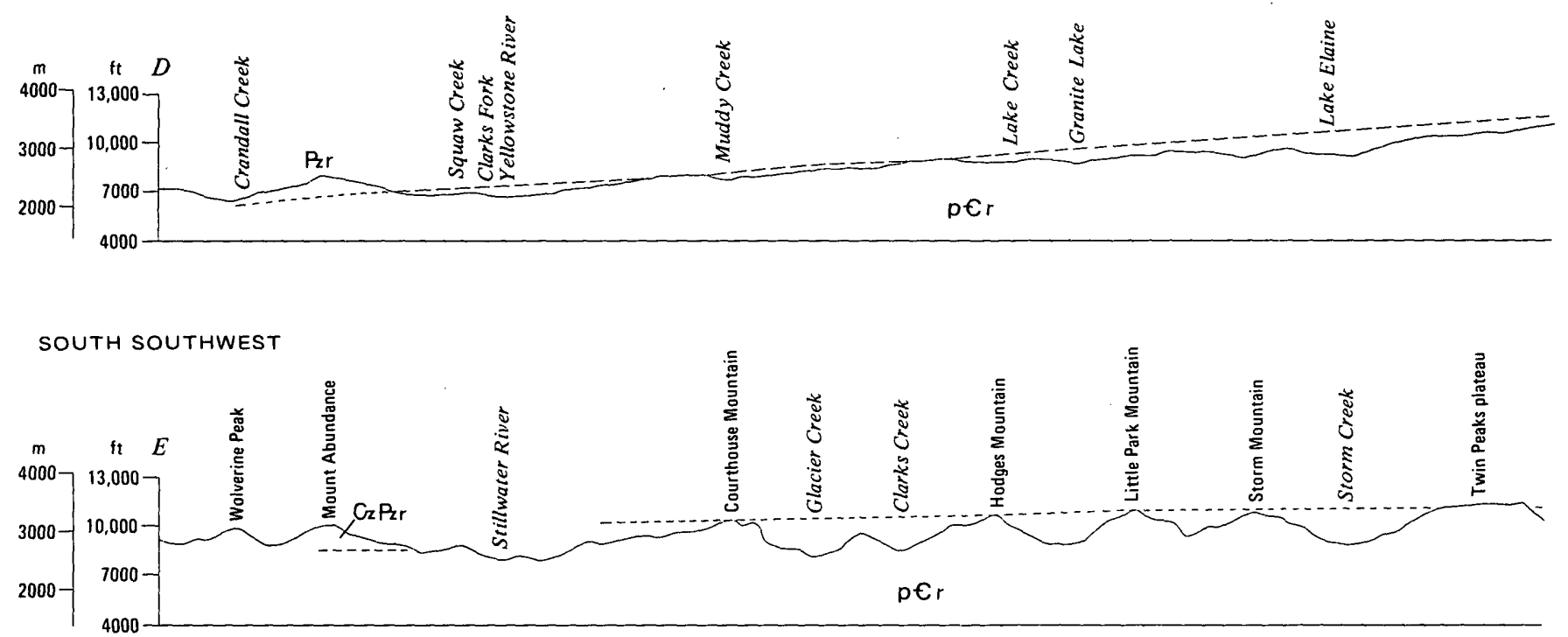

FIGURE 8.-Topographic profiles $A-A^{\prime}$ to $E-E^{\prime}$. Lines of profiles shown in figure 1. Geology shown 

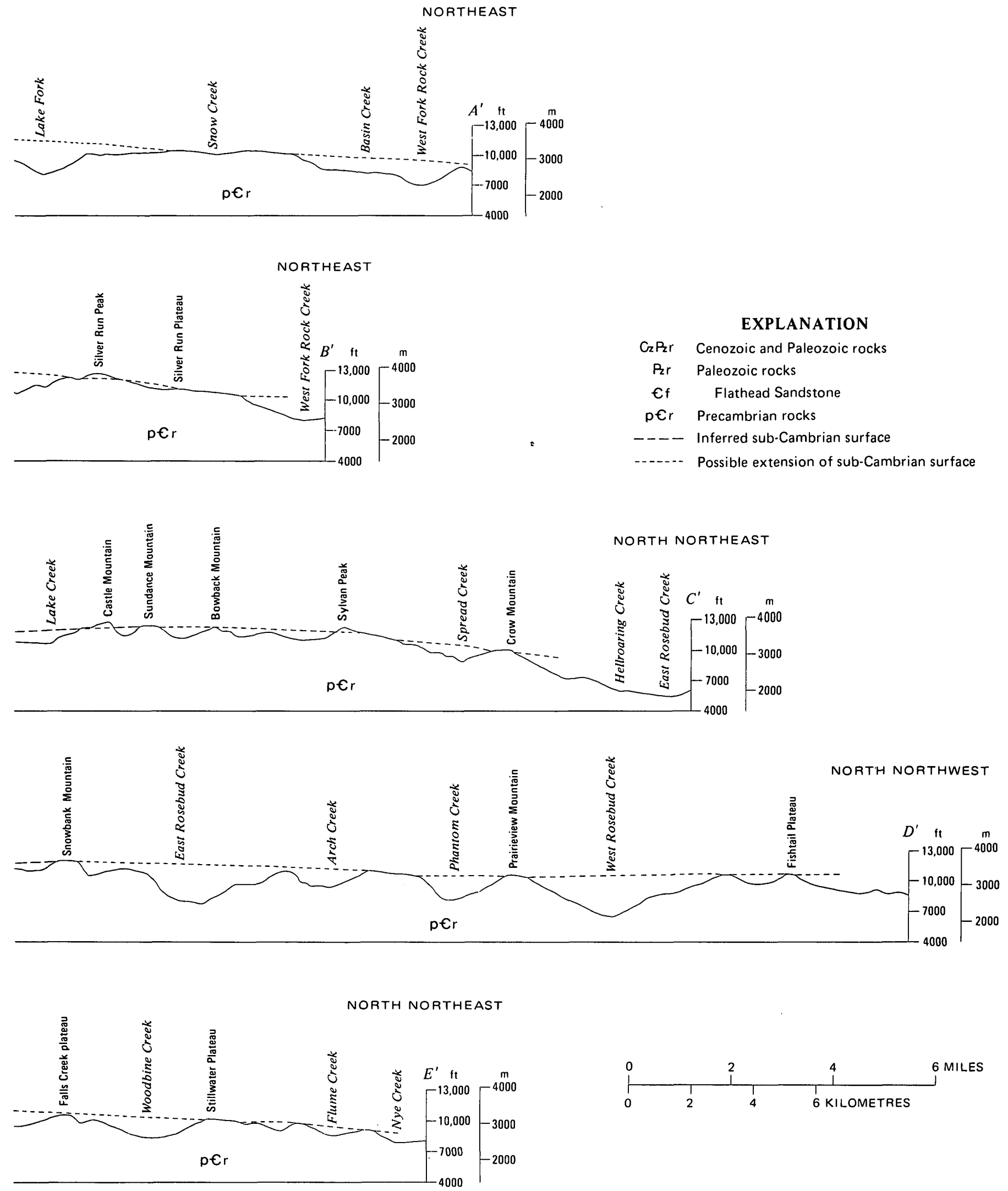

in the southern parts of profles $A-A^{\prime}$ to $D-D^{\prime}$, inclusive, is from Pierce and Nelson (1971), 


\section{REFERENCES CITED}

Bevan, Arthur, 1923, Summary of the geology of the Beartooth Mountains, Montana: Jour. Geology, v. 31, p. 441-465.

1945, Glacial drift on East Boulder Plateau, Beartooth Mountains, Montana [abs.] : Geol. Soc. America Bull., v. 56 , no. 12 , pt. 2 , p. 1147.

Foose, R. M., Wise, D. U., and Garbarini, G. S., 1961, Structural geology of the Beartooth Mountains, Montana and Wyoming: Geol. Soc. America Bull., v. 72, no. 8, p. 11431172.

Hughes, R. V., 1933, Peneplanation of the Beartooth Mountains: Pan-American Geologist, v. 59, p. 321-327.

Larsen, L. H., Poldervaart, Arie, and Kirchmayer, Martin, 1966, Geologic evolution of the Beartooth Mountains, Montana and Wyoming-Pt. 7, Structural homogeneity of gneisses in the Lonesome Mountain area: Geol. Soc. America Bull., v. 77, no. 11, p. 1277-1292.

Pierce, W. G., 1965, Geologic map of the Deep Lake quadrangle, Park County, Wyoming: U.S. Geol. Survey Geol. Quad. Map GQ-478.
Pierce, W .G., and Nelson, W. H., 1971, Geologic map of the Beartooth Butte quadrangle, Park County, Wyoming: U.S. Geol. Survey Geol. Quad. Map GQ-935.

Rouse, J. T., 1937, Genesis and structural relationships of the Absaroka volcanic rocks, Wyoming: Geol. Soc. America Bull., v. 48, no. 9, p. 1257-1295.

Sharp, H. S., 1938, The upland of the Beartooth Mountains, Montana [abs.] : Geol. Soc. America Proc. for 1937, p. 113.

Simons, F. S., Armbrustmacher, T. J., and Van Noy, R. M., 1973, Mineral resources of the Beartooth Primitive Area and vicinity, Carbon, Park, Stillwater, and Sweet Grass Counties, Montana, and Park County, Wyoming: U.S. Geol. Survey open-file rept., $207 \mathrm{p}$.

Smedes, H. W., and Prostka, H. J., 1972, Stratigraphic framework of the Absaroka Volcanic Supergroup in the Yellowstone National Park region: U.S. Geol. Survey Prof. Paper 729-C, $33 \mathrm{p}$.

Stow, M. H., 1938, Dating Cretaceous-Eocene tectonic movements in Big Horn Basin by heavy minerals: Geol. Soc. America Bull., v. 49, no. 5, p. 731-761.

Thom, W. T., Jr., Jones, O. T., and Chamberlin, R. T., 1935. Morphology of the Beartooth Mountains uplift [abs.]: Geol. Soc. America Proc. for 1934, p. 117. 


\title{
GEOLOGY OF THE BRYSCH URANIUM MINE, KARNES COUNTY, TEXAS
}

\author{
By KENDELL A. DICKINSON and MICHAEL W. SULLIVAN, \\ Denver, Colo.
}

\begin{abstract}
Approximately 13,700 tons $(12,400$ tonnes $)$ of oxidized uranium ore, averaging about 0.1 percent $\mathrm{U}_{3} \mathrm{O}_{8}$, was mined during 1966 and 1967 from the lower unit of the Deweesville Sandstone Member of the upper Eocene Whitsett Formation, from depths of 75 to 90 feet $(23-27 \mathrm{~m})$. The mine is in the Karnes County uranium area, 3 miles $(5 \mathrm{~km})$ east of Falls City, Tex. Meta-autunite, $\mathrm{Ca}\left(\mathrm{UO}_{2}\right)_{2}\left(\mathrm{PO}_{4}\right)_{2} \cdot 2-6 \mathrm{H}_{2} \mathrm{O}$, and meta-tyuyamunite, $\mathrm{Ca}\left(\mathrm{UO}_{2}\right)_{2}\left(\mathrm{PO}_{4}\right)_{2} \cdot 3-5 \mathrm{H}_{2} \mathrm{O}$, were identified in samples of the ore. The host rock is light-colored, medium-grained, well -sorted feldspathic sandstone that contains fossil wood and Ophiomorpha. It also contains clinoptilolite, cristobalite, and montmorillonite that probably formed as alteration products of volcanic grains in the original sediment. The host rock was deposited in a beach environment near or on a delta formed at the mouth of a stream channel oriented roughly normal to the beach. The Deweesville can be traced for many miles on the surface and represents in general the point of maximum transgression in a transgressive-regressive cycle. The upper unit of the Deweesville, which overlies the host rock, is now exposed in the mine and contains, in ascending order, storm-beach, shoreface, beach, and tidal-flat facies. The shape of the ore body suggests that it originated as an unoxidized ore roll. The ore-bearing fluids may have entered through porous fluvial rock extending updip. Plant material, abundant in the original host sediment, probably supplied reductant necessary for the roll formation.
\end{abstract}

Approximately 13,700 tons (12,400 tonnes) of oxidized uranium ore, averaging about 0.1 percent $\mathrm{U}_{3} \mathrm{O}_{8}$, was mined during 1966 and 1967 from the Frank Brysch uranium mine, 3 miles $(5 \mathrm{~km})$ east of Falls City, Tex. (figs. 1, 2). This production represents a small portion of the oxidized ore taken from several Karnes County mines in the early stage of mining in the area (Eargle and others, 1971; Eargle and others, 1975; and Bunker and MacKallor, 1973). The mine is, however, of considerable geologic interest because it is the deepest of the mines that contained oxidized ore in south Texas, because various sedimentary structures are well displayed in the upper part of the mine, and because, even though oxidized, the ore body still shows its original roll-front geometry (fig. 3 ).

The purpose of this paper is to record the geology of the mine, which originally extended to a depth of about

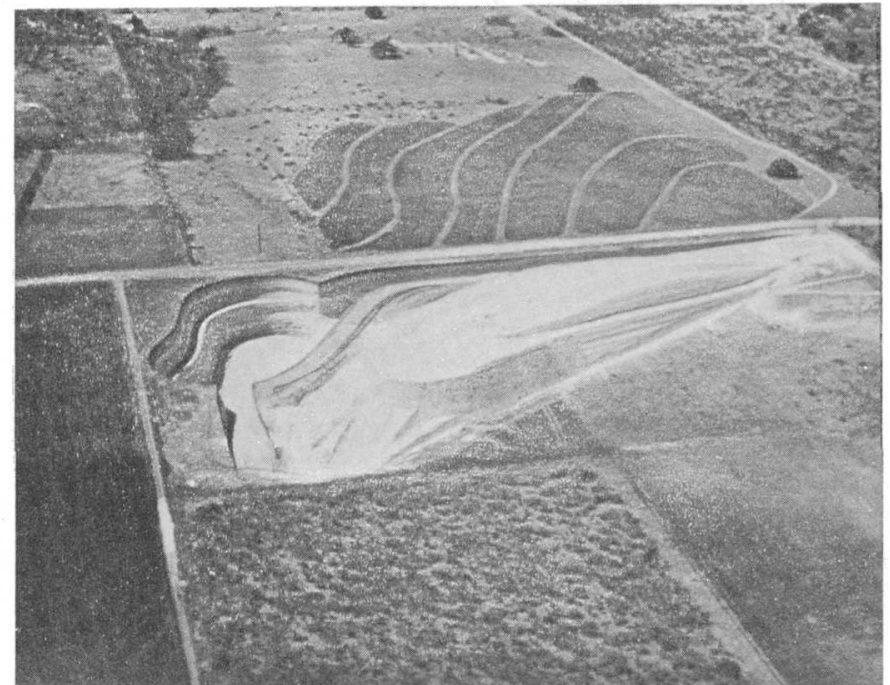

Figure 1.-Aerial view from the east of the Frank Brysch uranium mine, March 1967. (Photograph by John Osmond.)

90 feet $(27 \mathrm{~m})$ but now is filled with caved material and water to a depth of about 45 feet $(14 \mathrm{~m})$. The ore body was removed, but limited material is still available for study. Five samples from the ore horizon were obtained from the U.S. Geological Survey storage in Austin, Tex., and depths of ore and grade values were obtained from Continental Oil Co., Kenedy, Tex. These data together with photographs were the only data available from the lower unit of the Deweesville Sandstone Member at the mine. Other information about the Deweesville in Karnes and surrounding counties has been published (Eargle, 1972; Eargle and Weeks, 1973; Eargle and others, 1961; Eargle and others, 1971; Eargle and others 1975; Dickinson, 1975).

Acknowledgments.-Robert Maxwell, uranium exploration geologist for Continental Oil Co., Kenedy, Tex., was very helpful in making records of the mine available. The Elias Brysch family of Hobson, Tex., cooperated in allowing access to the mine and in giving permission to publish production data. 


\section{GEOLOGIC SETTING}

The Brysch uranium deposit is in the lower unit of the Deweesville Sandstone Member of the Whitsett Formation of the upper Eocene Jackson Group (fig. 2). The Whitsett Formation generally consists of continental, lagoonal, and marine facies. The continental facies consists of paludal mudstone, lignite, and fluvial mudstone and sandstone; the lagoonal facies is mainly fossiliferous clays; and the marine facies is largely fine-grained, well-sorted beach sandstone.

Units of the marine facies alternate vertically with the other facies to form the members of the Whitsett. In ascending order they are Dilworth Sandstone, Conquista Clay, Deweesville Sandstone, Dubose Clay, Tordilla Sandstone, and Fashing Clay. In Karnes County the composite thickness of the Whitsett is about 420 feet $(128 \mathrm{~m})$ (Eargle and others, 1975).

The uranium host rock in the Brysch mine is the Deweesville Sandstone Member, which is about 70 feet $(21 \mathrm{~m})$ thick at the mine. The Deweesville consists of two vertically stacked beach units. The lower unit contained the uranium ore. A vertical sequence through the upper unit is shown in figure 5. In the Brysch mine the Deweesville is overlain unconformably by a unit now believed to be the Catahoula Tuff but mapped as Dubose Member of the Whitsett Formation by Eargle, Trumbull, and Moxham (1961).

Units of the beach and lagoonal facies have limited updip and downdip extent, in some places no more than a mile or two, but they persist for many miles along the outcrop because the long axis of the deposit parallels the strike of the beds. The strike is northeast, and the dip, which is commonly about $1^{\circ}$, is southeast. The fluvial units are roughly normal to the ancestral shoreline and trend at right angles to the beach deposits.

\section{THE ORE BODY}

The ore body was at a depth ranging from about 80 to 90 feet $(24-27 \mathrm{~m})$; it was about 550 feet $(168 \mathrm{~m})$ long, 100 feet $(30 \mathrm{~m})$ wide, and 10 feet $(3 \mathrm{~m})$ thick. The long axis paralleled the regional strike, and its intermediate axis paralleled the dip. The shape of the ore body suggests that it originated as an unoxidized ore roll. The downdip or leading edge of the roll is relatively straight. The updip edge is irregular and tends to bifurcate (fig. 3).

The chief ore minerals of the deposit were apparently autunite $\mathrm{Ca}\left(\mathrm{UO}_{2}\right)_{2}\left(\mathrm{PO}_{4}\right)_{2} \cdot 10-12 \mathrm{H}_{2} \mathrm{O}$, and tyuyamunite, $\mathrm{Ca}\left(\mathrm{UO}_{2}\right)_{2}\left(\mathrm{VO}_{4}\right)_{2} \cdot 5-8 \mathrm{H}_{2} 0$. Both minerals have been previously reported from oxidized deposits in south Texas (Eargle and Weeks, 1961). The dehydrated forms meta-autunite and meta-tyuyamunite were the minerals actually identified by $\mathrm{X}$-ray diffraction, but dehydration of the ore probably occurred upon exposure during mining operations or during storage after samples of ore were removed from the mine. Five samples from in or near the ore horizon contained a trace or more of the ore minerals, and in one of these samples the ore minerals were abundant. The latter sample also contained much silicified wood.

The shape of the Brysch deposit indicates that it formed as an unoxidized ore roll in an oxidation-reduction cell. This now relict cell lies completely within an oxidizing environment, as indicated by the oxidation states of both the iron and uranium.

\section{HOST ROCK}

The sandstone in the lower unit of the Deweesville, at a depth of from 80 to 90 feet $(24-27 \mathrm{~m})$ in the mine, consists of well-sorted, medium-grained, feldspathic sandstone that was originally deposited in a beach environment. The upper unit of the Deweesville, from a depth of about 15 to 47 feet $(5-15 \mathrm{~m})$, consisted of light-yellowish-brown very fine grained to mediumgrained sandstone that was originally deposited in beach or various beach-related environments.

Grain counts and whole-rock X-ray diffraction studies were made for five samples from the lower, orecontaining unit. The grain counts gave an average of 54 percent quartz, 28 percent feldspar, and 16 percent clay. Estimates from $\mathrm{X}$-ray studies indicate as much as 40 percent feldspar. Plagioclase, orthoclase, including the variety sanidine, and microcline were identified optically and by X-ray diffraction. Many of the feldspar grains were difficult to identify optically because of alteration coating and corrosion. Small amounts of the zeolite, clinoptilolite, and alpha-cristobalite, together with the two ore minerals meta-autunite and meta-tyuyamunite, are present in all the samples from the ore zone. No clay minerals were found in these samples. A nearly white powder surrounding fossil wood in one sample was mostly alpha-cristobalite, but it also contained the two ore minerals. The alpha-cristobalite is present as small spherules and rosettes ranging in size from about 1 to 3 micrometres (fig. 4). These spherules are similar to the microscopic spheres of opal reported by Walton (1975) from altered tuffaceous rocks in west Texas. For the Brysch samples, the average mean grain size $\bar{X}$ is $1.7 \Phi$, the average standard deviation $\hat{\sigma}$ is 0.41 , and the average Riley sphericity is 0.78 .

The lower unit of the Deweesville Member was apparently deposited in a beach environment near or on a delta. The unit contains abundant fossil wood, some 


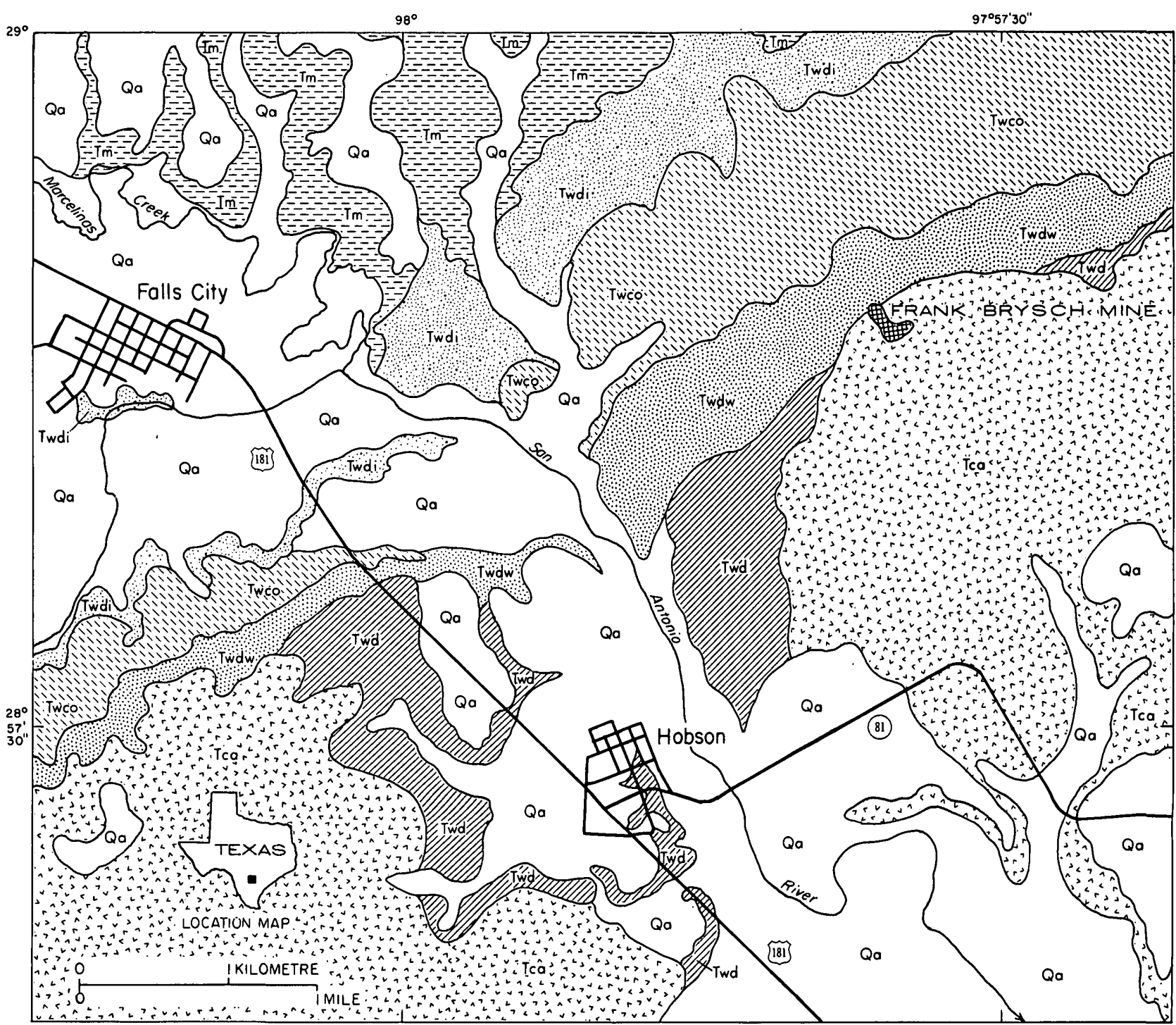

EXPLANATION

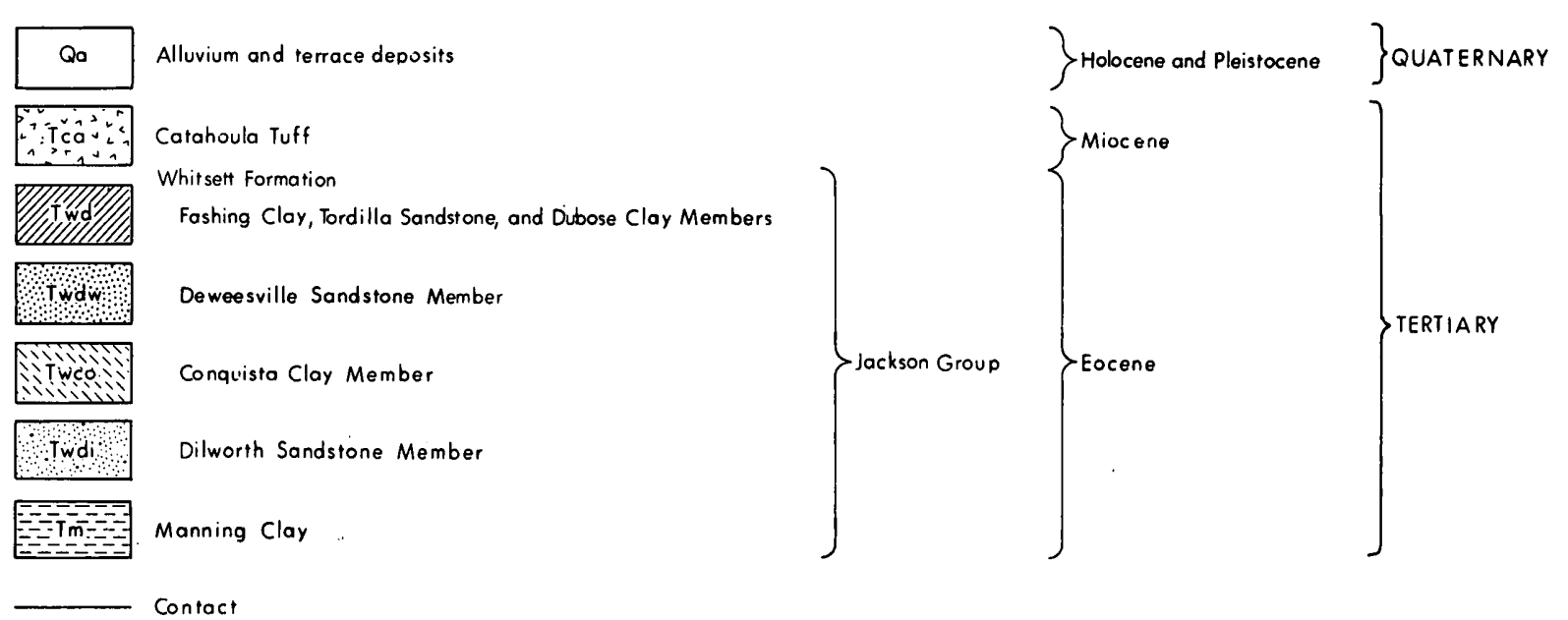

Figure 2.-Geologic map of part of Karnes County, showing the Brysch mine. Modified from Eargle, Trumbull, and Maxhom (1961). 

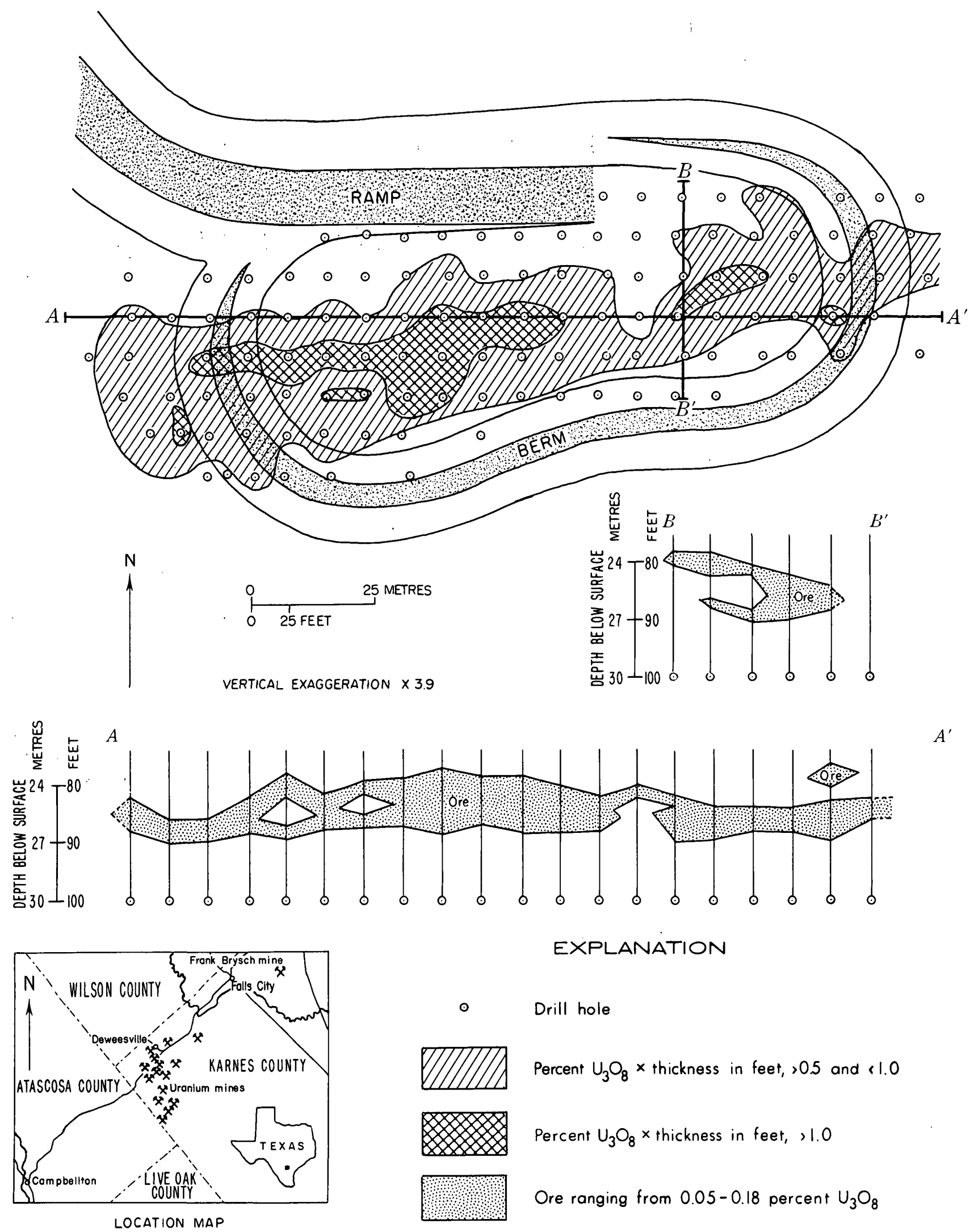

\section{EXPLANATION}

Drill hole

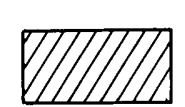

Percent $\mathrm{U}_{3} \mathrm{O}_{8} \times$ thickness in feet, $>0.5$ and $<1.0$

Percent $\mathrm{U}_{3} \mathrm{O}_{8} \times$ thickness in feet, $>1.0$

Ore ranging from $0.05-0.18$ percent $\mathrm{U}_{3} \mathrm{O}_{8}$

Frgure 3.-The distribution of ore in the Brysch deposit before mining. 


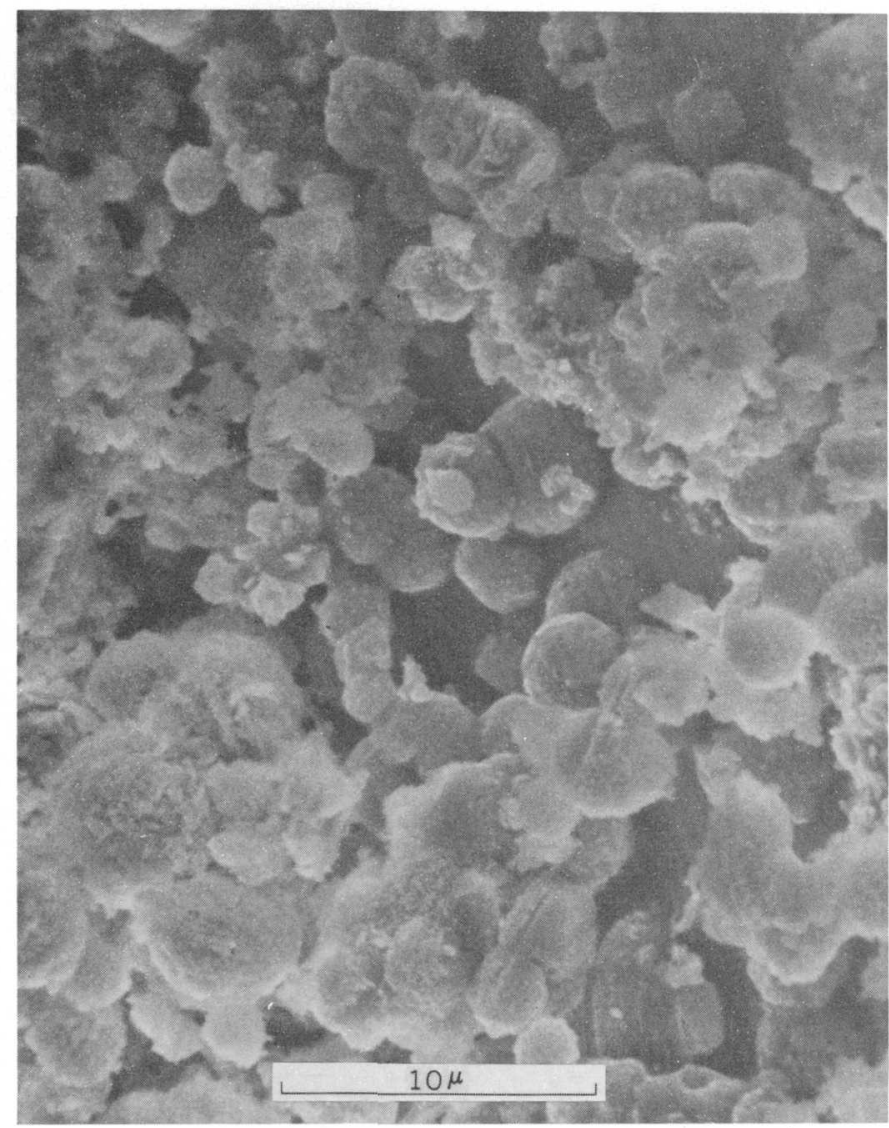

Figure 4.-Scanning electron micrograph of ore sample containing abundant alpha-cristobalite spherules and rosettes. ( $10 \mu=10$ micrometres. $)$

of which is in clusters that were described as "log jams" by Dave Norton (ERDA oral commun., 1972). Ophiomorpha sp., a burrow produced by a marine crustacean, is abundant in the unit and some of the wood was burrowed by Teredo clams or similar organisms. In general, beach-sandstone units in the Whitsett are fine grained and fluvial units are medium grained. The occurrence of medium sand in the lower unit suggests proximity of a fluvial source. The total thickness of the Deweesville at the mine is greater than normal, further suggesting a nearby fluvial source.

The upper unit of the Deweesville Member in this mine consists of a sequence of sandstone beds that were deposited, starting at the bottom, in storm-beach, shoreface, beach, and tidal-flat environments (figs. 5, 6) (Dickinson, 1973). Mineralogy and grain-size parameters vary throughout the sequence (fig. 6).

Four samples from the storm-beach facies were analyzed. All four contained abundant montmorillonite, and three contained volcanic glass shards (fig. 6). Apparently the glass shards altered directly to montmorillonite. Scanning electron micrographs (fig. 7)

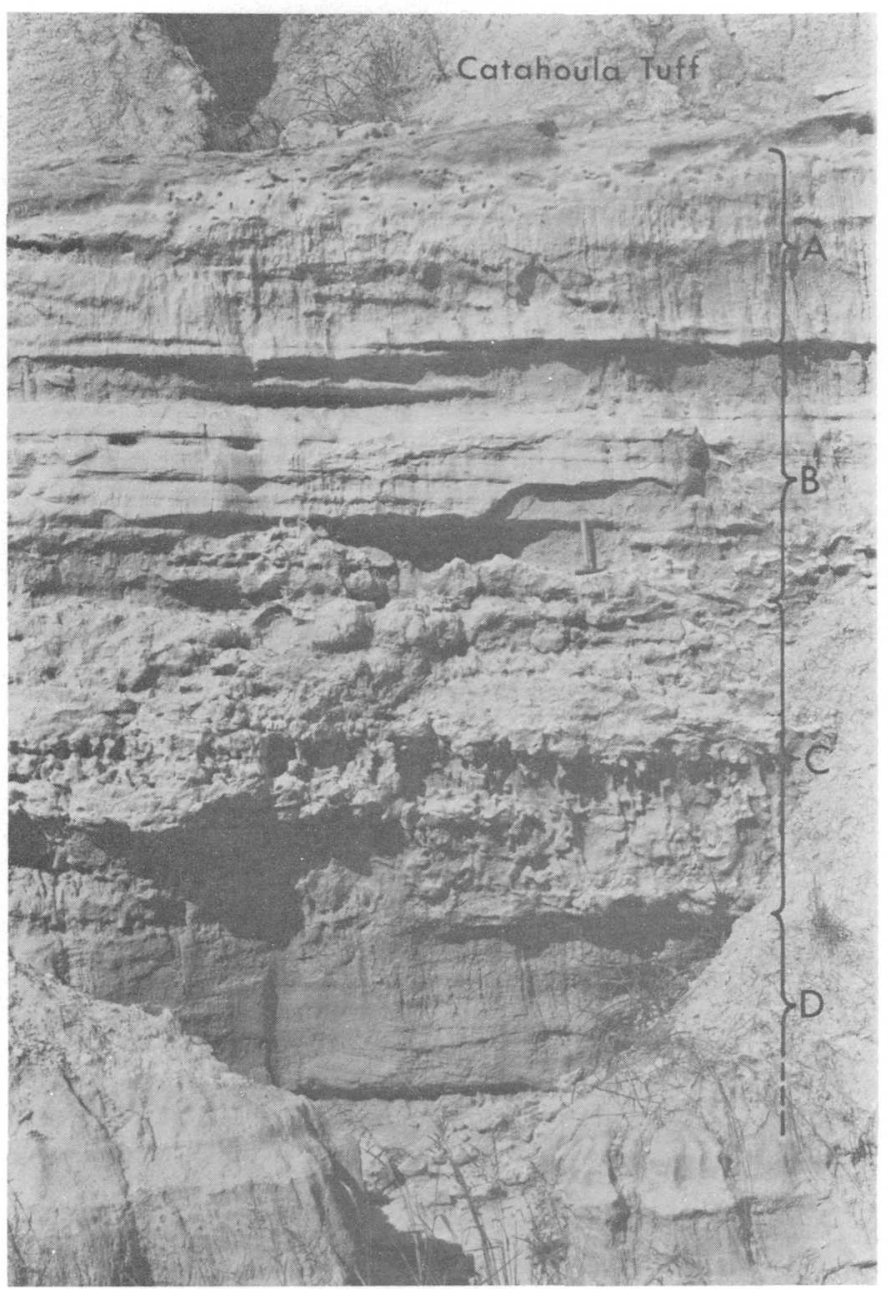

Figure 5.-Upper unit of Deweesville Sandstone Member in Brysch mine, showing (A) tidal flat, (B) beach, (C) shoreface, and (D) storm beach. Hammer is 13 inches $(33 \mathrm{~cm})$ long.

show tiny plates of montmorillonite clinging to the corroded shard surface. None of the samples from the overlying shoreface, beach, or tidal-flat facies contained either glass shards or montmorillonite; however, they contained clinoptilolite. The proportion of quartz and feldspar grains is less in the lower part of the section, where the volcanic shards are present. The sandstone is more mature in the upper part of the section, as indicated by the lack of shards there and the upward increase in the ratio of quartz to feldspar.

The mean grain size for all but two samples in the upper unit falls within the fine-size category (fig. 6). The sand is well sorted to moderately well sorted and shows a trend toward better sorting in the upper part. The sphericity is lowest in the lower part of the section and seems to reflect the volcanic shard. content of the sample. 

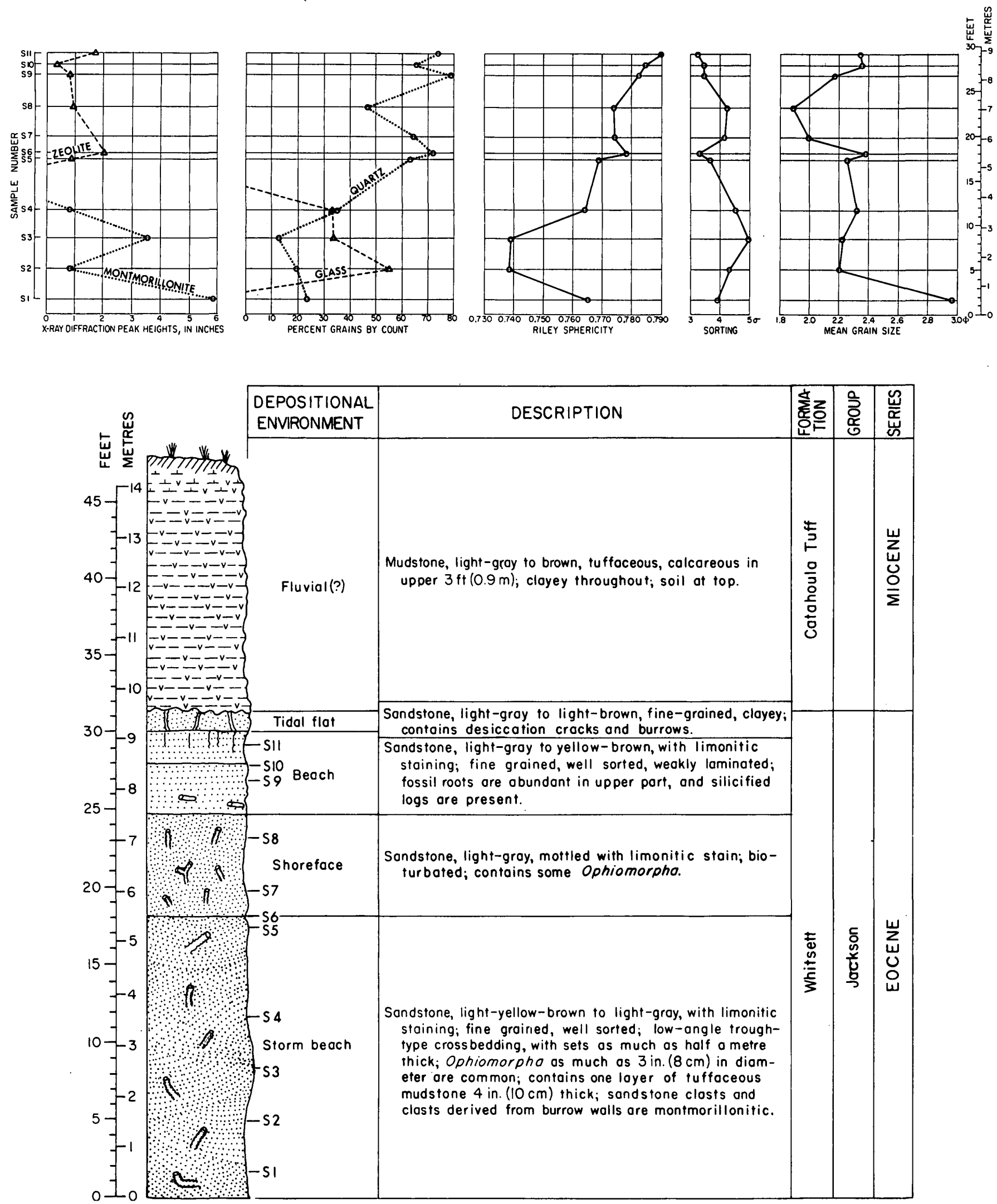

Fiaure 6.-Distribution of depositional environments, predominant minerals, grain-size statistics, and sphericity measurements in the upper unit of the Deweesville Sandstone Member. 

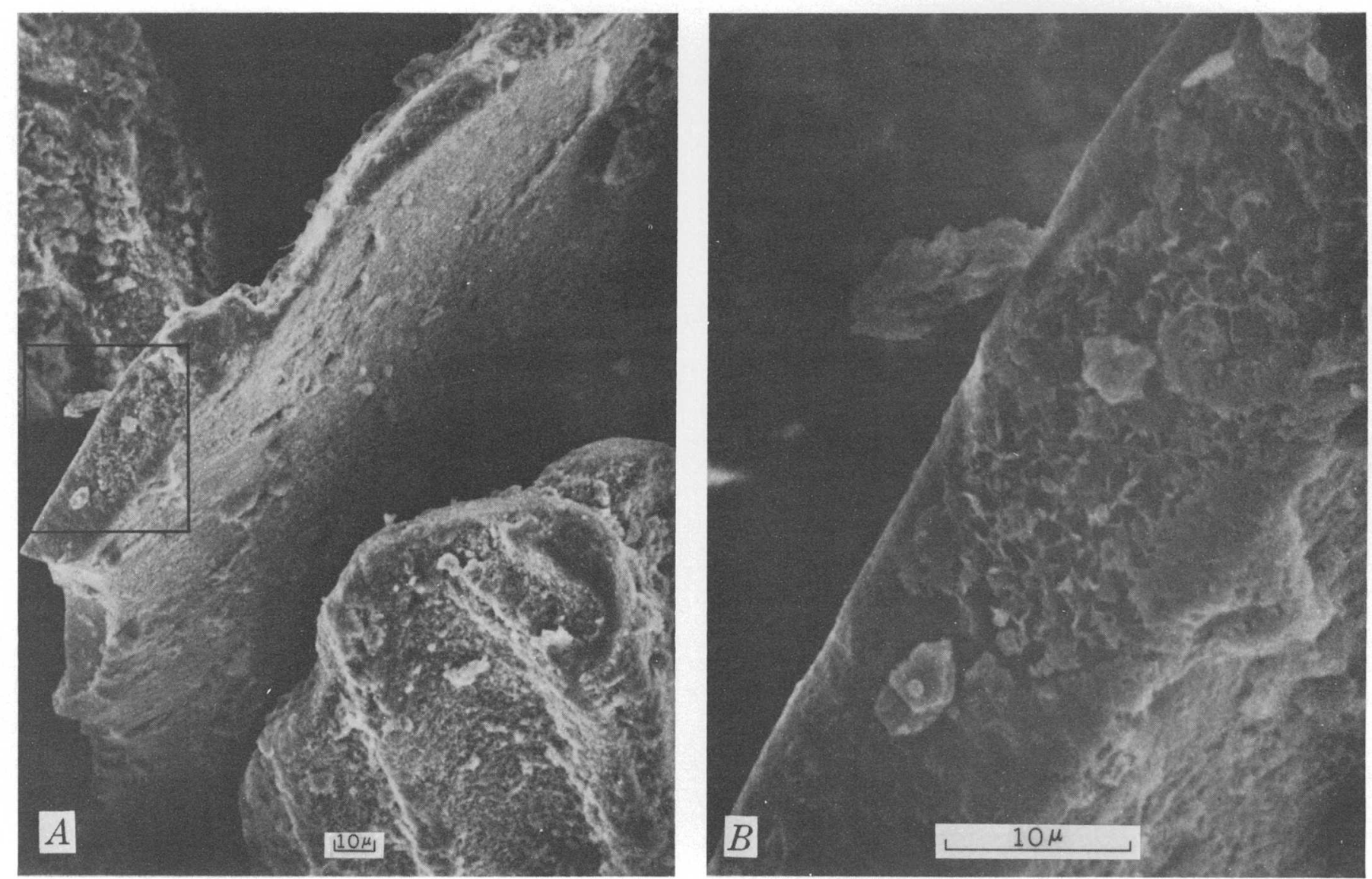

Figure 7.-Scanning electron micrographs of volcanic glass shards from the Brysch mine (sample S3, fig. 6.) $B$ is an enlargement of rectangle indicated on $A$. $(10 \mu=10$ micrometres. $)$

The sequence of beds in the upper unit of the Deweesville represents an abandoned, erosionally transgressive beach complex. The storm-beach facies shows low-angle trough-type crossbedding. The strongest crossbedding dip component is directed to the southwest, paralleling the ancestral shoreline and indicating the storm-generated longshore drift direction (fig. 8). Onshore and offshore crossbedding dip components are also indicated.

\section{ORIGIN OF THE DEPOSIT}

The ultimate source of the uranium in the Brysch and other south Texas deposits was primarily the Catahoula Tuff (Eargle and others, 1975). Tuffaceous rocks within the Whitsett Formation probably also contributed minor amounts. An intermediate source of uranium could have been an updip uranium deposit subsequently destroyed by dissolution or erosion. The uranium was dissolved from source rocks by alkaline ground water during periods of dry-climate weathering and transported by streams and through porous rock conduits to the depositional site where the urani- ferous solutions encountered a reducing chemical environment and the uranium was precipitated (Weeks and Eargle, 1963). For the Brysch mine, the porous rock conduit that carried the uranium to the depositional site was probably a fluvial sandstone connecting the beach-sandstone host rock to updip areas. The reductant was apparently an abundance of plant material in the beach sand. The absence of faulting and oil fields at or adjacent to the mine argue against a petroliferous source of reductant, such as hydrogen sulfide or methane gas. The porous rock probably also served as the conduit for later ground water that oxidized the deposit.

\section{METHODS}

Grain-size statistics were obtained from photographs of grain mounts. The inner and outer diameters were measured on the photographs with a Zeiss particle-size analyzer. The average number of grains measured for each sample was 192. The mean grain size $\bar{X}$ and standard deviation $\hat{\sigma}$ were calculated by the method of moments. Riley sphericity, RS, was calcu- 


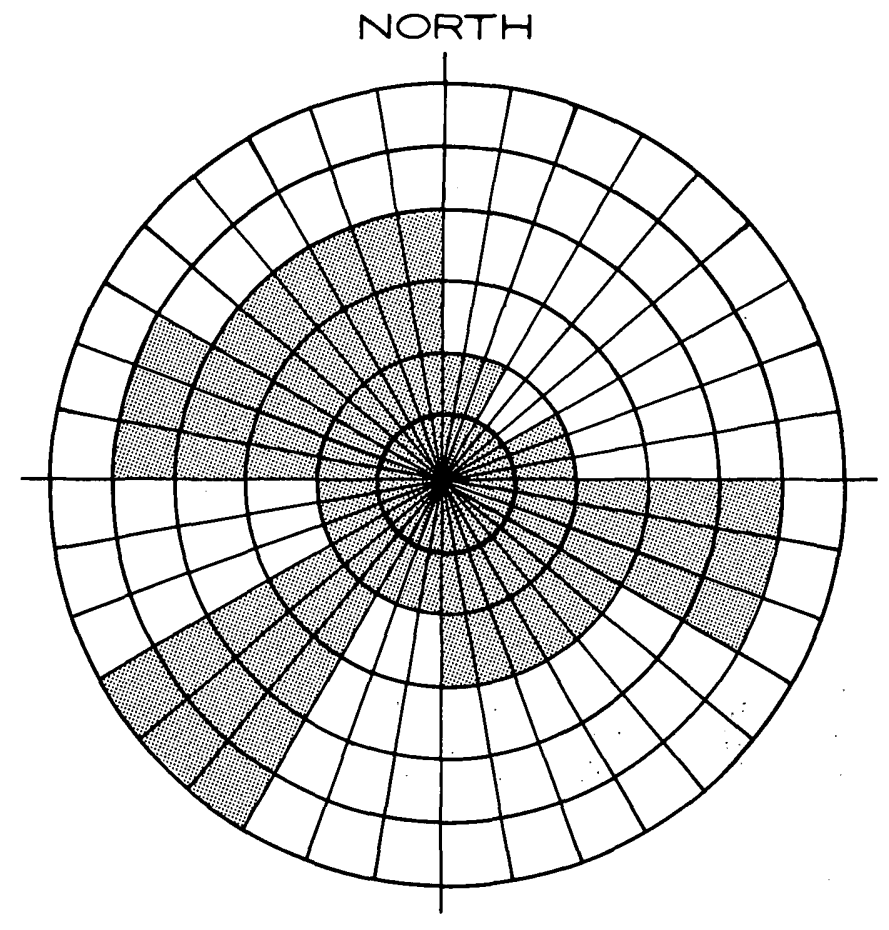

Fiaure 8.-Rose diagram constructed from 39 crossbed dip directions from the upper part of the Deweesville Sandstone Member in the Brysch mine.

lated for each sample using the formula $R S=\sqrt{D_{i} / D_{c}}$ The values used for $D_{i}$, inner diameter, and $D_{c}$, outer diameter, were average values for each sample. Mineralogy was studied using $\mathrm{X}$-ray diffraction and, in grain mounts, using a petrographic microscope.

\section{REFERENCES CITED}

Bunker, C. M., and MacKallor, J. A., 1973, Geology of the oxidized uranium ore deposits of the Tordilla Hill-Deeweesville area, Karnes County, Texas; A study of a district before mining: U.S. Geol. Survey Prof. Paper 765, $37 \mathrm{p}$.
Dickinson, K. A., 1973, Depositional environments as a guide to uranium exploration in south Texas [abs.]: Mining Eng., v. 25, no. 12, p. 57.

1975, Geologic map of the Tilden quadrangle, McMullen County, Texas: U.S. Geol. Survey Geol. Quad. Map GQ1246.

Eargle, D. H., 1972, Revised classification and nomenclature of the Jackson Group (Eocene), south-central Texas: Am. Assoc. Petroleum Geologists Bull., v. 56, no. 3, p. 561-566.

Eargle, D. H., Dickinson, K. A., and Davis, B. O., 1975, South Texas uranium deposits: Am. Assoc. Petroleum Geologists Bull., v. 59, no. 5, p. 766-779.

Eargle, D. H., Hinds, G. W., and Weeks, A. M. D., 1971, Uranium geology and mines, south Texas: Texas Univ. Bur. Econ. Geology Guidebook, no. 12, 61 p.

Eargle, D. H., Trumbull, J. V. A., and Moxham, R. M., 1961, Preliminary aeroradioactivity and geologic map of the Karnes City NW quadrangle, Karnes County, Texas: U.S. Geol. Survey Geophys. Inv. Map GP-251.

Eargle, D. H., and Weeks, A. M. D., 1961, Uranium-bearing clays and tuffs of south-central Texas, in Field excursion, central Texas, October 1961: Texas Univ. Bur. Econ. Geology Guidebook 3, p. 19-30.

1973, Geologic relations among uranium deposits, South Texas, Coastal Plain region, U.S.A., in Amstutz, G. C., and Bernard, A. J., eds., Ores in sediments, Internat. Sedimentological Cong., 8th, Heidelberg 1971: Berlin, New York, Springer-Verlag (Internat. Union of Geol. Sci., ser. A, no. 3), p. 101-113.

Walton, A. W., 1975, Zeolitic diagenesis in Oligocene volcanic sediments, Trans-Pecos Texas: Geol. Soc. America Bull., v. 86 , no. 5, p. 615-624.

Weeks, A. M. D., and Eargle, D. H., 1963, Relation of diagenetic alteration and soil-forming processes to the uranium deposits of the southeast Texas Coastal Plain, in Clays and clay minerals, v. 10-Natl. Conf. Clays and Clay Minerals, 10th, 1961, Proc.: New York, Macmillan Co. (Internat. Ser. Mons. Earth Sci., v. 12), p. 23-41. 
Jour. Research U.S. Geol. Survey
Vol. 4, No. 4, July-Aug. 1976, p. $405-414$

\title{
GEOLOGY AND Rb-Sr AGES OF REACTIVATED PRECAMBRIAN GNEISSES AND GRANITE IN THE MARENISCO-WATERSMEET AREA, NORTHERN MICHIGAN
}

\author{
By P. K. SIMS and ZELL E. PETERMAN, Denver, Colo.
}

\begin{abstract}
Rb-Sr dating of Precambrian W (lower Precambrian) gneisses and granitic rocks that form the cores of antiforms or domes mantled by metamorphosed Precambrian $\mathrm{X}$ (middle Precambrian) bedded rocks in the MareniscoWatersmeet area, northern Michigan, shows that the rock systems have been disturbed to different degrees by complex tectonic and thermal events subsequent to primary crystallization. The disturbance is indicated by a lowering of the wholerock $\mathrm{Rb}-\mathrm{Sr}$ ages of many samples of gneiss from 2,600 m.y. or older to about 1,800 m.y. and by the scattering of data points, although some of the points can be fit to secondary isochrons; probably the major mechanism was redistribution of previously accumulated radiogenic $\mathrm{Sr}$, which is indicated by the high initial ${ }^{87} \mathrm{Sr} /{ }^{80} \mathrm{Sr}$ of the resultant isochrons. The disturbance is interpreted as having resulted from internal cataclasis and recrystallization accompanied by metamorphic segregation and (or) partial melting during reactivation of the gneisses about 1,800 m.y. ago. Variations in the degree of reconstitution and mobility of individual bodies of basement rocks are indicated by differences in structural reconstitution of the basement rocks and in the metamorphic grade of the Precambrian $\mathrm{X}$ bedded rocks.
\end{abstract}

Detailed geologic mapping of the Precambrian terrane in northern Michigan during the past 30 years by the U.S. Geological Survey has shown the existence of a consistent tectonic pattern. Precambrian W (lower Precambrian) gneisses and granitic rocks form the cores of antiforms or domes that are mantled by Prer cambrian $\mathrm{X}$ (middle Precambrian) bedded rocks (James and others, 1961; Gair and Thaden, 1968; Aldrich and others, 1965), assigned to the Marquette Range Supergroup (Cannon and Gair, 1970). The mapped gneiss domes differ from classic mantled gneiss domes in that a concordant foliation between the gneiss and the mantling Marquette Range Supergroup is lacking because the bedded rocks truncate the internal foliation of the gneisses in the axial region of the antiforms.

In the central part of the Upper Peninsula, which has been mapped and studied intensively because of the several significant iron-mining districts in this area, differential uplift of the Precambrian $W$ gneisses has been interpreted as having taken place largely by mechanical disruption on high-angle faults at the basement-cover interface (James and others, 1961; Cannon, 1973; Klasner and Cannon, 1974), with consequent draping of the bedded rocks over the older gneisses. A low-pressure type of regional metamorphism accompanied the deformation but reached a culmination after deformation. The metamorphism is of generally low grade and surrounds nodes of sillimanitegrade metamorphism, which James (1955) named the Republic and Peavy metamorphic nodes. No major granitic bodies were formed during the orogenic cycle (Penokean orogeny, Cannon, 1973) in the central part of northern Michigan, although small pegmatite and granite bodies cut rocks of the Marquette Range Supergroup (James and others, 1961; Aldrich and others, 1965; Cannon and Simmons, 1973). Accordingly, James (1955) concluded that metamorphism of the Precambrian $\mathrm{X}$ rocks was the result of long-continued flow of heat outward from subjacent magma.

In the Marenisco-Watersmeet area, in the western part of the Upper Peninsula, the Precambrian W gneisses and granitic rocks show evidence of having been somewhat mobile during their reactivation, for from field relationships they appear to be both older and younger than the Precambrian $\mathbf{X}$ bedded rocks. Also, in one part of the area (Watersmeet metamorphic node of James, 1955), the metamorphic mineral zoning pattern is spatially related to one of the bodies of gneiss and possibly is related genetically to it as well.

This paper is an outgrowth of $\mathrm{Rb}-\mathrm{Sr}$ dating that was done to support geologic mapping in the MareniscoWatersmeet area by the U.S. Geological Survey. The mapping was done by C. E. Fritts, who mapped the Thayer, Watersmeet, and part of the Marenisco 15minute quadrangles (Fritts, 1969), and by V. A. Trent, who mapped the Wakefield NE $71 / 2$-minute quadrangle and the remainder of the Marenisco quadrangle 
(Trent, 1973). Both Fritts and Trent collected the analyzed samples are shown on figure 1 and descripsamples for $\mathrm{Rb}-\mathrm{Sr}$ analysis. The localities for the tions are given in table 1 .

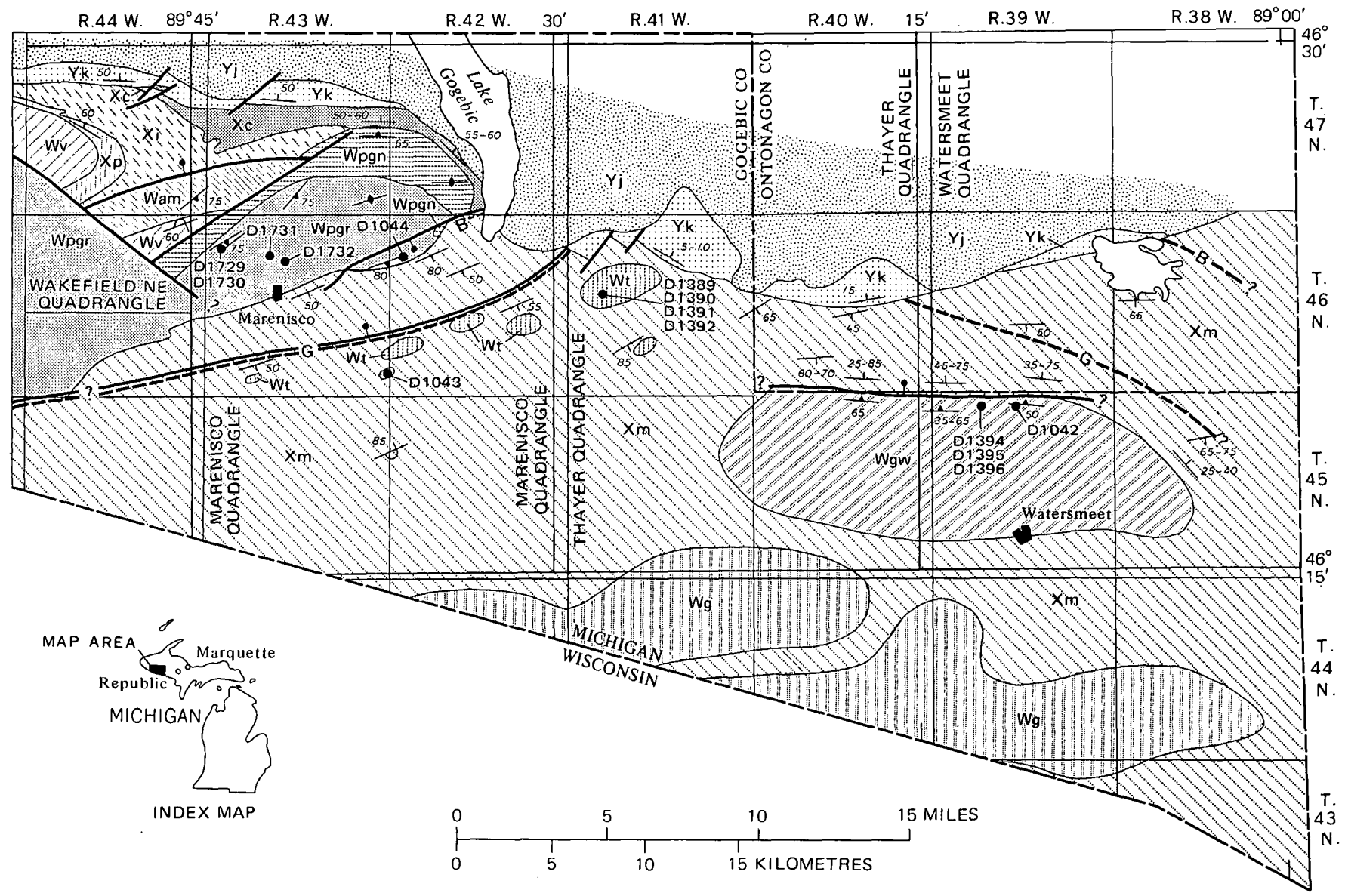

PRECAMBRIAN Y

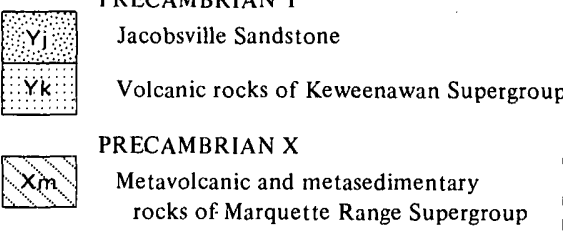

PRECAMBRIAN W

Presque Isle Granite

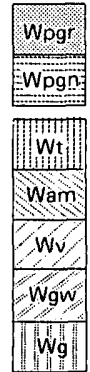

Granite

Gneiss

Granite near Thayer

Amphibolite

Mafic volcanic rocks

Gneiss at Watersmeet

Gneiss

EXPLANATION

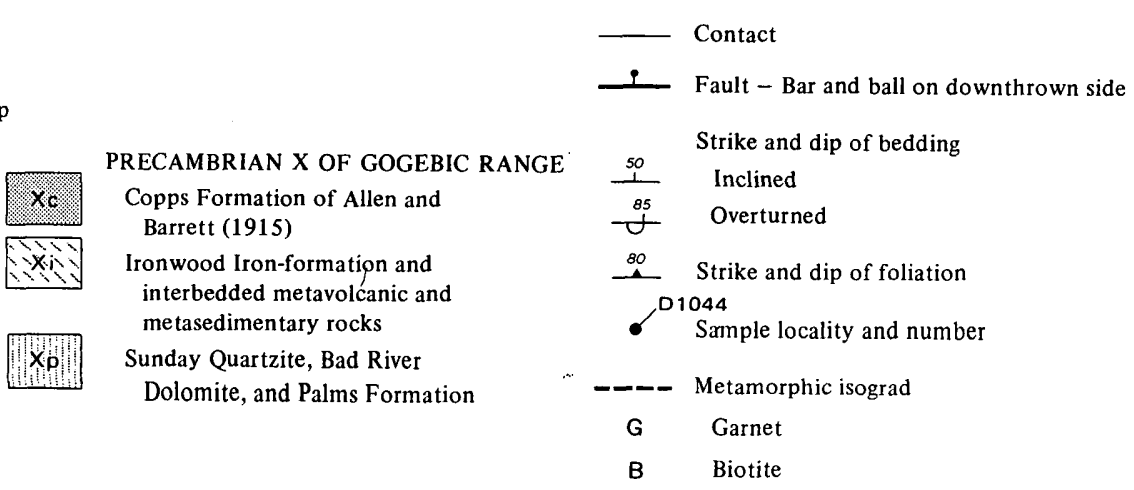

Fraure 1.-Generalized geologic map of Marenisco-Watersmeet area, northern Michigan. Compiled and modifled by P. K. Sims from Fritts (1969) and Trent (1973). 
Table 1.-Sample descriptions

[Sampling by C. E. Fritts and V. A. Trent. Sample localities are shown in fig. 1]

\begin{tabular}{|c|c|c|c|c|c|c|c|}
\hline \multicolumn{2}{|c|}{ Sample No. } & \multirow{2}{*}{$\begin{array}{l}\text { Collector } \\
\text { and year }\end{array}$} & & \multicolumn{3}{|c|}{ Sample locality } & \multirow{2}{*}{ Description } \\
\hline Lab. & Fleld & & & Sec & T. $\mathbf{N}$ & R. W. & \\
\hline \multicolumn{8}{|c|}{ Presque Isle Granite } \\
\hline D1044 & $65-M-14$ & Fritts, 1965 & ----------- & 7 & 46 & 42 & $\begin{array}{l}\text { Pinkish-gray medium-grained weakly foliated equigranular } \\
\text { biotitic granite has allotriomorphic granular texture. } \\
\text { Perthitic microcline ( } 31 \text { percent) embays and corrodes } \\
\text { larger anhedral grains of moderately altered plagioclase } \\
\text { ( } 33 \text { percent). Plagioclase has rims of albite and, locally, } \\
\text { myrmekite adjacent to microcline grains. Biotite ( } 3 \text { per- } \\
\text { cent) occurs in stubby aggregates associated with micro- } \\
\text { cline and muscovite; these minerals are later paragenet- }\end{array}$ \\
\hline
\end{tabular}

D1729 VT-67-10 Trent, 1967

$7 \quad 46$

43

cally than plagioclase. Modal quartz is 33 percent.
Pink medium- to coarse-grained granite with megacrysts of white and pink feldspar has typical mortar structure; sodic plagioclase (43 percent), K-feldspar ( 22 percent), quartz ( 31 percent), and biotite (4 percent) are partly granulated and recrystallized; retrograde metamorphism, indicated by partial alteration of biotite to green chlorite, epidote, and opaque iron oxides, accompanied cataclasis. $K$-feldspar is perthitic microcline; it is poikilitic and includes sodic plagioclase with albite rims, quartz, and biotite; it embays and replaces plagioclase. Plagioclase is moderately altered to sericite and clay minerals.

D1730 VT-67-11 Trent, 1967 _

43 Pink inequigranular leucogranite; in part pegmatitic; moderate gramulation. Similar to D1729. Quartz, 31 percent; sodic plagioclase, 40 percent; K-feldspar, 26 percent; biotite, 3 percent. K-feldspar is slightly perthitic microcline; it embays and poikilitically includes sodic plagioclase with albite rims. Biotite, partly altered to chlorite and epidote.

$9 \quad 46$

43 Pink medium-coarse-grained granite pegmatite has moderate granulation. Quartz, 30 percent; sodic plagioclase, 18 percent; K-feldspar, 50 percent; biotite, 2 percent. Kfeldspar is slightly perthitic microcline; it poikilitically includes plagioclase.

D1732 VT-67-97 Trent, 1967 _-_._-_ $946 \quad 43$ Pinkish-gray fine-medium-grained foliated biotite granite with allotriomorphic granular texture. Quartz is highly strained. Similar to D1729. Quartz, 31 percent; sodic plagioclase, 31 percent; K-feldspar, 34 percent; biotite, 4 percent.

Bell Creek Gneiss, Republic Area

D1040 65-R-1 Fritts, 1965 _.
gneiss. Plagioclase is moderately altered to muscovite and clay minerals, has albite rims adjacent to $K$-feldspar, and is myrmekitic when surrounded by K-feldspar. K-feldspar is a perthitic microcline. Quartz is strained. Biotite is dark greenish brown, slightly chloritized; locally intergrown with muscovite. Texture is xenomorphic granular.

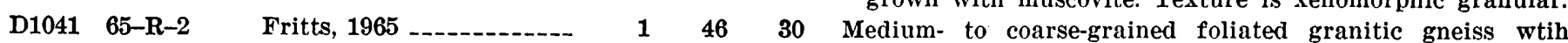
tabular K-feldspar megacrysts as much as $8 \mathrm{~mm}$ long.

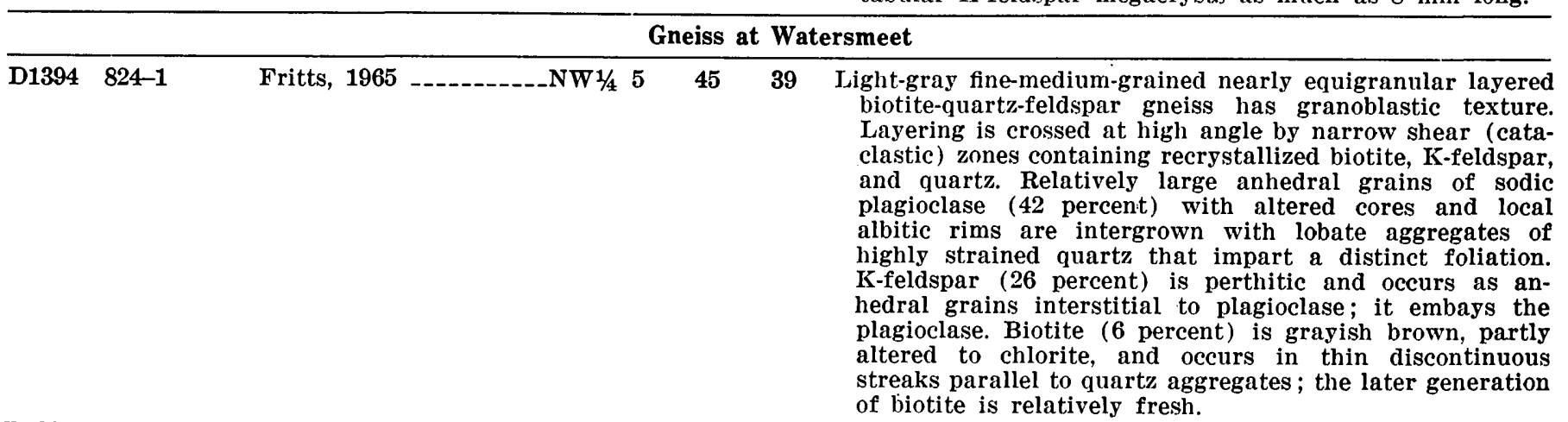

D1395 824-2

Fritts, 1966 $-N W 1 / 45$
45 of biotite is relatively fresh.

39 Similar to D1394, but coarser grained and distinctly inequigranular. Relatively large, anhedral, altered plagioclase crystals are surrounded by smaller anhedral grains of granulated and recrystallized (unaltered) plagioclase, quartz (24 percent), and K-feldspar (5 percent). Biotite 
TARLE 1.-Sample descriptions-Continued

\begin{tabular}{llll}
\hline \multicolumn{2}{c}{ Sample No. } & $\begin{array}{c}\text { Collector } \\
\text { and year }\end{array}$ & \multicolumn{2}{c}{ Sample locality } & Description \\
\cline { 4 - 4 } Lab. & Field & Sec. T. N. R. W. & \\
\hline & & Gneiss at Watersmeet-Continued & \\
\hline
\end{tabular}

D1396 824-3

Fritts, 1966 NW1/4 $5 \quad 45$

D1042 65-W1

Fritts, 1965 NW $1 / 4$ SE1/4 4

45

39

(6 percent) is associated with the K-feldspar and unaltered plagioclase. Rock has typical mortar structure. Modal plagioclase is 65 percent.

\begin{tabular}{|c|c|c|c|c|c|}
\hline & & 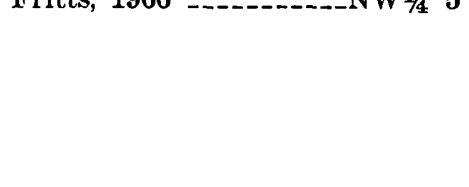 & & & $\begin{array}{l}\text { two orientations, parallel to cataclastic zones; it is gray- } \\
\text { ish brown and partly altered to chlorite and opaque iron } \\
\text { oxides. A later generation of biotite in narrow shear } \\
\text { (cataclastic) zones is associated with } K \text {-feldspar (11 per- } \\
\text { cent), quartz ( } 32 \text { percent), and sodic plagioclase (52 } \\
\text { percent). }\end{array}$ \\
\hline D1042 & 65-W1 & Fritts, $1965-\ldots$ NW $1 / 4$ SE $1 / 44$ & 45 & 39 & $\begin{array}{l}\text { Medium-gray medium- to coarse-grained layered feldspathic } \\
\text { gneiss; D1042, irregular aggregates of an anedral plagio- } \\
\text { clase grains and of quartz grains define a weak foliation. } \\
\text { Biotite is well oriented and partly chloritized. Plagioclase } \\
\text { is highly altered to muscovite and some calcite. Microcline } \\
\text { ( }<1 \text { percent) is interstitial. Texture is granoblastic. } \\
\text { D1042b, granitic dike that cuts dominant gneiss; D1042h, } \\
\text { medium- to coarse-grained augen gneiss; D1042j, similar } \\
\text { to D1042h but more feldspathic. All samples were col- } \\
\text { lected from same roadcut. }\end{array}$ \\
\hline
\end{tabular}

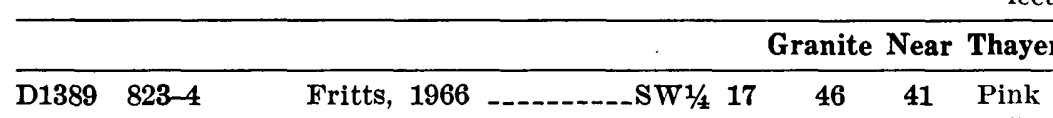
lected from same roadcut.

\begin{tabular}{|c|c|c|c|c|c|c|}
\hline D1389 & $823-4$ & Fritts, 1966 & $-\ldots-S W 1 / 417$ & 46 & 41 & $\begin{array}{l}\text { Pink coarse-grained inequigranular granitic gneiss or } \\
\text { gneissic pegmatite has typical mortar structure; sodic } \\
\text { plagioclase ( } 24 \text { percent) and to a lesser extent K-feldspar } \\
\text { (45 percent) are partly granulated and recrystallized } \\
\text { with a mosaic texture; quartz ( } 26 \text { percent) also is granu- } \\
\text { lated and recrystallized. K-feldspar occurs as large poiki- } \\
\text { litic, anhedral grains with inclusions of quartz and } \\
\text { plagioclase; some microcline perthite grains have patches } \\
\text { of sodic plagioclase, interpreted as a breakdown of per- } \\
\text { thite to microcline and plagioclase. Grayish-brown biotite } \\
\text { (5 percent) is crinkled and replaced parallel to crinkles } \\
\text { by a younger generation of biotite. }\end{array}$ \\
\hline D1390 & $823-5$ & Fritts, 1966 & $-\ldots$ SW1/4 17 & 46 & 41 & $\begin{array}{l}\text { Pink medium- to coarse-grained inequigranular granitic } \\
\text { gneiss or foliated pegmatite. Similar to D1389. Quartz, } 30 \\
\text { percent; sodic plagioclase, } 20 \text { percent; K-feldspar, } 47 \text { per- } \\
\text { cent; biotite, } 3 \text { percent. }\end{array}$ \\
\hline D1391 & $823-6$ & Fritts, 1966 & -.SW1/4 17 & 46 & 41 & $\begin{array}{l}\text { Pinkish-gray fine-grained weakly foliated granitic gneiss } \\
\text { has granoblastic texture; minerals are strained but not } \\
\text { granulated. Foliation is given by alined biotite (4 per- } \\
\text { cent) and quartz ( } 34 \text { percent) aggregates. Relatively } \\
\text { large, anhedral altered plagioclase (46 percent) grains are } \\
\text { locally embayed by K-feldspar (16 percent); some myr- } \\
\text { mekite developed in plagioclase adjacent to K-feldspar. }\end{array}$ \\
\hline D1392 & $823-7$ & Fritts, 1966 & - SW1/4 17 & 46 & 41 & $\begin{array}{l}\text { Mottled gray and white crudely layered hornblende-plagio- } \\
\text { clase gneiss. Plagioclase occurs as megacrysts as much } \\
\text { as } 1.5 \mathrm{~mm} \text { long. Hornblende occurs as (1) an early gen- } \\
\text { eration of weakly oriented green hornblende, partly al- } \\
\text { tered to chlorite, and }(2) \text { strongly oriented, green has- } \\
\text { tingsitic hornblende associated with sphene in narrow } \\
\text { granulated zones. Plagioclase is strongly sausseritized. }\end{array}$ \\
\hline D1043 & $65-M-1$ & Fritts, 1965 & NE1/4 36 & 46 & 43 & $\begin{array}{l}\text { Streaked pink and gray fine- to medium-grained fiaser gran- } \\
\text { ite gneiss contains scattered plagioclase megacrysts in a } \\
\text { fine-grained foliated matrix of plagioclase, quartz, micro- } \\
\text { cline, biotite, and hornblende (1 percent). }\end{array}$ \\
\hline
\end{tabular}

\section{GENERAL GEOLOGY}

Four crudely elliptical bodies of gneisses and granite have been distinguished in the Marenisco-Watersmeet area (fig. 1). The westernmost body, exposed at the eastern end of the Gogebic range, is the easternmost part of a large granitic pluton named the Presque Isle Granite by Allen and Barrett (1915); it consists largely of granite but contains some associated gneisses and schists. A second body, exposed sparsely in the vicinity of Watersmeet, was called the Wolf Lake Granite by Allen and Barrett (1915), but, because it consists mainly of gneisses, it is herein designated informally as the gneiss at Watersmeet. Approximately midway between the Presque Isle Granite and the Watersmeet body, mainly in T. 46 N., Rs. 41 and 42 W., are numerous small outcrops of heterogeneous 
gneisses, granite, and pegmatite, which have been referred to collectively by the informal name granite near Thayer (Fritts, 1969). The two other elliptical bodies astride the Michigan-Wisconsin boundary are not exposed, so far as known, but are inferred to consist of gneisses similar to those in the Watersmeet body.

Except for the east end of the Gogebic range (Trent, 1973; Prinz, 1967), the Precambrian X (Marquette Range Supergroup) bedded rocks in the area have not been formally designated and are not subdivided on figure 1. C. E. Dutton (written commun., 1974) has reinterpreted the several Precambrian X units mapped by Fritts (1969) as consisting basically of two stratigraphic units: (1) Interbedded iron-formation and mafic-intermediate volcanic rocks, with lesser clastic sedimentary rocks, and (2) interbedded iron-formation and argillite and graywacke. The latter is younger than unit 1 and is correlated by Dutton with the Michigamme Formation in the Marquette region (James, 1958; Cannon and Gair, 1970). The Copps Formation of Allen and Barrett (1915), which overlies the Ironwood Iron-formation on the eastern Gogebic (fig. 1), is equivalent to unit 2 of Dutton, above; presumably, it is also equivalent to the Tyler Slate of the Gogebic range (Atwater, 1938).

The Precambrian $\mathrm{X}$ rocks were metamorphosed prior to Precambrian $\mathrm{Y}$ (Keweenawan) time, and they lie within the Watersmeet metamorphic node as defined by James (1955). Approximate garnet and biotite isograds, taken from Fritts (1969), are shown on figure 1. As can be seen, the gneiss at Watersmeet and the bodies comprising the granite near Thayer (Fritts, 1969) lie within the garnet zone of metamorphism.

The granitic gneisses and Precambrian $\mathrm{X}$ strata are overlain unconformably in the northern part of the map area (fig. 1) by Precambrian $\mathrm{Y}$ (Keweenawan) volcanic rocks and the Jacobsville Sandstone.

\section{Presque Isle Granite}

The Presque Isle Granite, as defined by Allen and Barrett (1915, fig. 2A, p. 50-54), constitutes the core of a northeast-trending antiform (Trent, 1973) at the eastern end of the Gogebic range (fig. 1). Except for its northwest margin, it is unconformably overlain by steeply dipping, weakly metamorphosed Precambrian $\mathrm{X}$ bedded rocks. In T. $47 \mathrm{~N}$., R. $43 \mathrm{~W}$., on the north side of the Presque Isle Granite, the Precambrian X Copps Formation of Allen and Barrett (1915) contains a local basal conglomerate that has boulders of the underlying granitic rocks as much as 5 feet in diameter (Allen and Barrett, 1915, p. 55). Judged from mapping in the Marenisco quadrangle (Trent, 1973), the Palms Formation, which directly underlies the Ironwood Iron-formation, also was deposited directly on the Presque Isle Granite in secs. 21, 22, and 23 , T. 47 N., R. 43 W. ; it is weakly metamorphosed and contains primary sedimentary structures that face northward, away from the gneiss. The Palms Formation in T. 47 N., R. 43 W., is included on figure 1 with the Ironwood Iron-formation.

On the other hand, most investigators (Allen and Barrett, 1915; Atwater, 1938; Trent, 1973) have noted the local presence of relatively small stringers of granite, pegmatite, microgranite, and quartz-feldspar veins in the weakly metamorphosed Precambrian $\mathbf{X}$ rocks adjacent to the Presque Isle Granite: these observations have led to debate about the age of all or part of it. Allen and Barrett (1915, p. 50-54) concluded from field relationships that the Presque Isle Granite is younger than the Ironwood Iron-formation but is older than the Copps Formation, because the Copps contains boulders of granitic rocks. Atwater $(1938$, p. 186) concluded that "The presence of these *** veins invading the lower horizons of the Copps Formation suggests a granite invasion $* * *$ following the deposition of the Upper Huronian. If these veins are apophyses of the Presque Isle granite $* * *$ this granite must be considered to be at least post-Copps in age." Both Fritts (1969) and Trent (1973) interpreted the Presque Isle Granite as being Precambrian $\mathrm{W}$ in age, because the associated gneisses (Wpgn on fig. 1) are more intensely metamorphosed than the overlying Copps Formation and boulders of granite are present in the basal beds of the Copps.

Fritts (1969) mapped two general rock types within the Presque Isle Granite: (1) Gray fine- to mediumgrained layered gneisses, including amphibolite, with admixed granitic rocks, which he called gneiss near Mount Kimberly, and (2) medium- to coarse-grained pinkish-gray granite and minor pegmatite, which he called granite near Nelson Creek. He interpreted the gneisses as being metasedimentary and (or) metavolcanic rocks of moderate metamorphic grade. Similarly, Trent (1973) mapped two facies of the Presque Isle Granite: (1) A border facies transitional from granite outward to gneisses and schist, and (2) granite, with local xenoliths of the rock types found in the border facies. The two general rock types are distinguished on figure 1. Abundant dikes of metadiabase (Precambrian X or $\mathrm{W}$ ) and diabase (Precambrian $\mathrm{Y}$ ), both of which are subparallel to the foliation, transect both rock units.

The foliation within both the gneisses and the granite trends northeastward and dips steeply, mainly to 
the southeast; lineations plunge moderately northeastward (Trent, 1973; Fritts, 1969). The foliation is subconformable to the steep bedding in the overlying Precambrian $\mathbf{X}$ bedded rocks except at the northeast end (axial region) of the antiform, where the bedding in the Copps Formation of Allen and Barrett (1915) sharply truncates the foliation.

The granitic rocks (granite near Nelson Creek of Fritts, 1969), which were sampled for $\mathrm{Rb}-\mathrm{Sr}$ dating, contain sodic plagioclase, $\mathbf{K}$-feldspar, and quartz in approximately equal amounts and sparse biotite and muscovite and have a hypidiomorphic granular texture. The $\mathrm{K}$-feldspar is perthitic and tends to form large anhedral crystals that poikilitically include and embay plagioclase; plagioclase in contact with the $K$-feldspar has narrow albitic rims and, locally, myrmekitic intergrowths of quartz. Except for sample D1044, the rocks have been weakly cataclastically deformed. The cataclasis was accompanied by extensive chloritization of biotite.

\section{Granite near Thayer}

The small bodies mapped by Fritts (1969) as granite near Thayer occupy a rather narrow northeast-trending zone within metamorphosed (garnet-grade) Precambrian X strata (fig. 1). Fritts (1969) interpreted the rocks as being intrusive into the bedded rocks, but contacts are poorly exposed and field relationships are equivocal.

The rocks composing the granite near Thayer are granitic gneisses and associated amphibolite, granite, and granite pegmatite. Judged from the available samples, the gneisses are grossly similar mineralogically to the rocks composing the gneiss at Watersmeet but differ in having less evidence of cataclastic deformation and recrystallization. Description of the analyzed samples are given in table 1.

\section{Gneiss at Watersmeet}

The gneiss at Watersmeet is a poorly exposed, elliptical body about $24 \mathrm{~km}$ (15 mi) long and $7 \mathrm{~km}(4.4 \mathrm{mi})$ wide (fig. 1); it occupies an area of about $17 \mathrm{~km}^{2}$. Fritts (1969) inferred that the gneiss is bounded on the north by a fault, which separates it from metamorphosed argillite-graywacke, but the boundary may be a normal stratigraphic contact; elsewhere, the gneiss is overlain stratigraphically by the same argillitegraywacke or by an iron-formation unit that is interbedded with it. Where exposed along and near its northern margin, foliation within the gneiss is subparallel to the contact and dips moderately steeply outward. Bedding in the argillite-graywacke is subparallel to the gneiss-cover contact for a distance of
$1 \mathrm{~km}$ away from the contact (fig. 1) ; farther outward, the bedding strikes approximately east, subparallel to the regional trend in the eastern part of the map area, and dips moderately steeply southward. As noted earlier, the metamorphic grade in the bedded rocks increases toward the gneiss, and the garnet isograd is about $4 \mathrm{~km}$ from the contact and approximately conforms to the outline of body.

Fritts (1969) followed Allen and Barrett (1915) in interpreting the gneiss at Watersmeet (Wolf Lake Granite of Allen and Barrett, 1915) as having intruded the adjacent Precambrian $\mathrm{X}$ bedded succession because (1) inclusions in the gneiss strongly resemble the adjacent Precambrian $\mathrm{X}$ argillite-graywacke, and (2) the metamorphic grade of the metasedimentary rocks increases markedly toward the body of gneiss.

Where exposed, the gneiss at Watersmeet consists dominantly of a medium-gray medium-grained layered feldspathic augen gneiss and lesser light- or mediumgray fine- to medium-grained biotite-quartz-feldspar gneiss. The augen consist of intergrown plagioclase and quartz and are sheared out in the foliation plane and locally obliterated. Both rock types, and particularly the biotite gneiss, are transected by numerous thin irrègularly oriented cataclastic zones marked by abundant new biotite. At locality D1042 (fig. 1), narrow fine-grained granitic dikes and white quartzfeldspar pegmatite containing miarolitic cavities cut both major rock types. Thin metadiabase dikes (Precambrian $\mathrm{W}$ or $\mathrm{X}$ ) transect the gneisses. Inclusions of garnetiferous and, locally, staurolite-bearing biotite schist (metagraywacke) are common in the exposed gneiss; judged by their hornfels texture, relict bedding, and composition, the inclusions are Precambrian $\mathrm{X}$ metagraywacke.

In thin section, the biotite-quartz-feldspar gneiss is fine- to medium-grained and partly inequigranular and consists dominantly of plagioclase and quartz. In the more inequigranular phases, larger anhedral plagioclase grains commonly are surrounded by anhedral plagioclase, K-feldspar, quartz, and biotite. The $\mathbf{K}$ feldspar is perthitic. The rocks have a well-defined mortar structure. The medium- to coarse-grained feldspathic gneiss is more granulated than the biotite gneiss and distinctly layered.

\section{ISOTOPIC DATA AND INTERPRETATIONS}

Whole-rock and mineral samples of the gneisses and granitic rocks (table 2) were analyzed for $\mathrm{Rb}, \mathrm{Sr}$, and ${ }^{87} \mathrm{Sr} /{ }^{86} \mathrm{Sr}$ by conventional methods previously described (Peterman and others, 1967). Analytical uncertainties in the laboratory at the time the analyses were com- 
TABLE 2.-Analytical data

[Suffix letters on sample number indicate type of sample analyzed: $R$, whole rock; $M i$, microcline; Pl plagioclase ]

\begin{tabular}{|c|c|c|c|c|}
\hline Sample & $\mathrm{Rb}(\mathrm{ppm})$ & Sr (ppm) & ${ }^{87} \mathrm{Rb} /{ }^{80} \mathrm{Sr}$ & ${ }^{*}{ }^{87} \mathrm{Sr} /{ }^{86} \mathrm{Sr}$ \\
\hline \multicolumn{5}{|c|}{ Presque Isle Granite } \\
\hline D1044R & 237 & 50.9 & 13.50 & 1,2033 \\
\hline D1729R & 119 & 180 & 1.93 & .7793 \\
\hline D1730R & 118 & 174 & 1.97 & .7775 \\
\hline D1731R & 133 & 60.1 & 6.51 & .8989 \\
\hline D1732R & 54.4 & $79 . \overline{7}$ & 1.99 & .7816 \\
\hline \multicolumn{5}{|c|}{ Bell Creek Gneiss, Republic area } \\
\hline D1040R & 204 & 66.5 & 8.88 & 1.0294 \\
\hline D1041R & 256 & 72.2 & 10.28 & 1.0739 \\
\hline \multicolumn{5}{|c|}{ Gneiss at Watersmeet } \\
\hline D1394R & 95.2 & 98.2 & 2.81 & 0.8139 \\
\hline D1395R & 89.1 & 240 & 1.08 & .7560 \\
\hline D1396R & 57.3 & 118 & 1.42 & .8087 \\
\hline D1042R & 149 & 132 & 3.32 & .8478 \\
\hline $\mathrm{D} 1042 \mathrm{bR}$ & 168 & 57.7 & 8.55 & .9901 \\
\hline D1042hR & 167 & 69.5 & 7.07 & .9430 \\
\hline D1042jR & 176 & 94.6 & 5.46 & .9096 \\
\hline $\mathrm{D} .1042 \mathrm{jPl}$ & 25.3 & 32.4 & 2.26 & .8356 \\
\hline & 26.4 & 33.0 & 2.32 & .8369 \\
\hline D1042jMi & 369 & 115 & 9.26 & 1.0022 \\
\hline \multicolumn{5}{|c|}{ Granite near Thayer } \\
\hline D1389R & 135 & 111 & 3.50 & 0.8391 \\
\hline D1390R & 126 & 88.7 & 4.10 & .8538 \\
\hline D1391R & 99.3 & 164 & 1.75 & .7723 \\
\hline D1392R & 91.0 & 243 & 1.09 & .7413 \\
\hline D1043R & 118 & 119 & 2.88 & .7829 \\
\hline
\end{tabular}

- Normalized to ${ }^{8} \mathrm{Sr} /{ }^{88 \mathrm{Sr}}=0.1194$

pleted were \pm 2 percent for ${ }^{87} \mathrm{Rb} /{ }^{86} \mathrm{Sr}$ and \pm 0.0005 for ${ }^{87} \mathrm{Sr} /{ }^{86} \mathrm{Sr}$ (both at 2 sigma). The decay constant for ${ }^{87} \mathrm{Rb}$ used in the age calculations is $1.39 \times 10^{-11} \mathrm{yr}^{-1}$. The data indicate that most of the rocks sampled behaved as open systems with respect to $\mathrm{Sr}$ and $\mathrm{Rb}$ as a result of their severe thermal and tectonic history.

The data for the granitic samples of the Presque Isle Granite plot on a 2,610-m.y. isochron (fig. 2). Unfor-

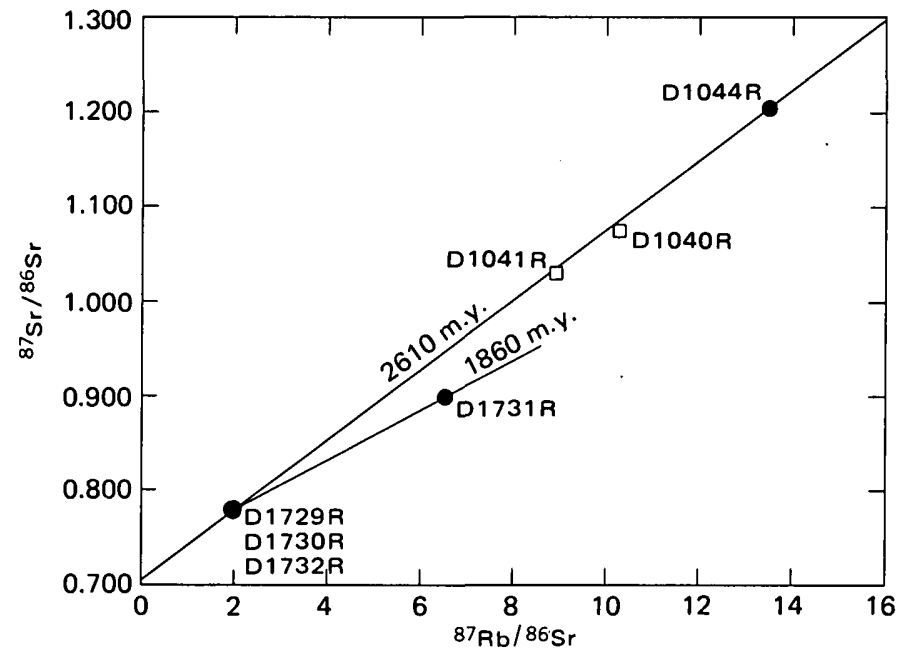

Fraure 2.-Rb-Sr isochron plot for samples of the Presque Isle Granite (dots) and Bell Creek Gneiss (squares). tunately, the distribution of $\mathrm{Rb} / \mathrm{Sr}$ ratios is less than optimum because three of five samples have similar values. Two samples from the Bell Creek Gneiss of the Republic area, about $48 \mathrm{~km}$ (30 mi) west of Marquette (Cannon and Simmons, 1973; Van Schmus and Woolsey, 1975), are also included, and these are consistent with the 2,610-m.y. isochron. One sample from the Presque Isle Granite (D1731), which is granite pegmatite, lies well below the isochron. An isochron through it and the cluster of three points, which represents samples from the same general area as the pegmatite, indicate an age of 1,860 m.y. A lower initial ${ }^{87} \mathrm{Sr} /{ }^{86} \mathrm{Sr}$ ratio $(0.705)$ would give an apparent age of 2,100 m.y.

Although the data are limited, the 2,610-m.y. isochron for the granite, which is a minimum age, clearly indicates that the Presque Isle Granite is Precambrian $W$ in age. The younger age of the granite pegmatite (D1731R) may indicate either that (1) simple open system conditions existed as a result of a younger metamorphic event, or (2) the pegmatite actually is younger and perhaps was derived by palingenesis some 700 m.y. after initial crystallization of the granite. Probably, the granitic veins in the low-grade metasedimentary rocks adjacent to the Presque Isle Granite are similar in age and origin to the pegmatite.

Data for the gneiss at Watersmeet and the granite near Thayer (Fritts, 1969) (fig. 3) cannot be fit by a single isochron. Useful information can be obtained, however, from their scatter. Sampling of these bodies was necessarily restricted to the few outcrops from which fresh rock could be obtained. Samples of the gneiss at Watersmeet were obtained from two localities, one represented by the D1042 series and the other by the group D1394, D1395, and D1396 (localities shown

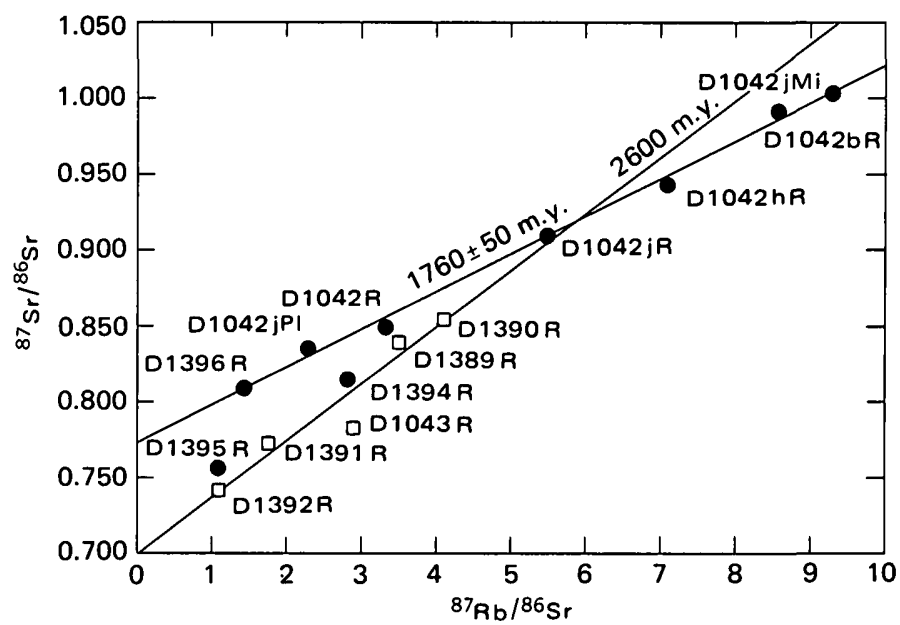

Figure 3.-Rb-Sr isochron plot for samples of the gneiss at Watersmeet (dots) and granite near Thayer (squares). 
on fig. 1). Except for D1043, samples of the granite near Thayer were obtained from a single locality. Inspection of the data on figure 3 shows that the D1042 series and D1396, from the Watersmeet body, fit a single isochron reasonably well; by using the York (1969) regression, an age of 1,760 550 m.y. was calculated, with an initial ${ }^{87} \mathrm{Sr} /{ }^{86} \mathrm{Sr}$ of $0.7732 \pm 0.0044$. This array includes data for plagioclase and microcline from D1042j, which support our belief that the isochron is geologically meaningful. Samples D1394 and D1395 of the gneiss at Watersmeet and those of the granite near Thayer do not plot on or close to the 1,760-m.y. isochron.

In evaluating data for disturbed whole-rock systems from the Black Hills of South Dakota, Zartman and Stern (1967) suggested that rock bodies may approximate closed systems on a scale much larger than individual samples. From their whole-rock data, they calculated an average "total rock" point or hypothetical composite and, from this, they estimated the primary age. Using this technique for the gneiss at Watersmeet, the average "total rock" determined from data defining the 1,760-m.y. isochron (excluding the mineral analyses) gives an age of 2,860 m.y., assuming an initial ratio of 0.700 . This total rock age has a large uncertainty but indicates that the primary age of the gneiss is Precambrian W. On figure 3, a reference isochron of 2,600 m.y. is drawn for comparison of the data with the isochron for the Presque Isle Granite (fig. 2).

The mechanisms of disturbance of whole-rock $\mathrm{Rb}$ $\mathrm{Sr}$ systems are poorly known. If a sample that has remained closed for a period of time after its formation is subsequently disturbed by a metamorphic event, the sample can be displaced from the primary isochron by gain or loss of $\mathrm{Rb}$, radiogenic $\mathrm{Sr}$, or both; $\mathrm{Rb}$ gain and radiogenic $\mathrm{Sr}$ loss will move the point to the right and below the primary isochron, whereas radiogenic $\mathrm{Sr}$ gain or $\mathrm{Rb}$ loss will move the point to the left and above. In interpreting disturbed mineral systems, it often is assumed that some sort of homogenization of $\mathrm{Sr}$ isotopes occurred at the time of disturbance. Brooks (1968) has shown that this is an extremely complex process-radiogenic $\mathrm{Sr}$, common $\mathrm{Sr}$, and $\mathrm{Rb}$ can be lost from $\mathrm{K}$-feldspar and gained by secondary minerals associated with the alteration of the plagioclase.

Migration of $\mathrm{Sr}$ and (or) $\mathrm{Rb}$ can result from shearing and recrystallization with consequent rotation of the isochron and lowering of apparent ages( Zartman and Stern, 1967). In severe dynamic metamorphism, whole-rock $\mathrm{Rb}-\mathrm{Sr}$ systems are effectively reset (Hanson and others, 1969; Hunziker, 1970; Abbott, 1972). Redistribution of previously accumulated radiogenic $\mathrm{Sr}$ is indicated by high initial ${ }^{87} \mathrm{Sr} /{ }^{88} \mathrm{Sr}$ of the resultant secondary isochrons. Processes of migmatization also result in migration of $\mathrm{Sr}$ and (or) $\mathrm{Rb}$ between leucosomes and melanosomes, and, when these phases are produced by anatexis or metamorphic segregation, $\mathrm{Sr}$ isotopic equilibrium can be inferred or shown to have obtained (Pidgeon and Compston, 1965; Gorokhov and others, 1970; Hedge, 1972; Grauert and others, 1974). With the establishment of compositional banding in high-grade metamorphic rocks, either as a primary feature or by migmatization, subsequent migration of $\mathrm{Rb}$ and $\mathrm{Sr}$ resulting from later metamorphism at least as high as amphibolite grade appears to be limited and restricted to narrow zones at lithologic boundaries (Krogh and Davis, 1973). In the studies cited above, the $\mathrm{Rb}-\mathrm{Sr}$ data, even though complex, produced systematics that were interpretable in a geologic context.

Migration of $\mathrm{Sr}$ and (or) $\mathrm{Rb}$ can also result from thermal metamorphism without accompanying cataclasis or migmatization. Lanphere and others (1964) showed that thermal metamorphism of 1,800-m.y.-old granitic and gneissic rocks in Mesozoic time resulted in significant migration of $\mathrm{Sr}$ even though primary minerals, textures, and structures were preserved. Consequently, the Rb-Sr ages of the rocks were lowered, but the data points scattered and a secondary isochron was not produced.

The $\mathrm{Rb}$-Sr data for the gneiss at Watersmeet (fig. 3) show that radiogenic $\mathrm{Sr}$ was mobile on a scale larger than that of the samples. Inasmuch as the samples were not collected near a major lithologic boundary, where simple thermal metamorphism could produce isotopic and chemical reequilibration (Krogh and Davis, 1973), it is unlikely that thermal metamorphism alone can account for the Rb-Sr systematics. Instead, the disturbance of the $\mathrm{Rb}-\mathrm{Sr}$ system must have resulted from more complex superposed events. As noted earlier, the gneiss at Watersmeet consists of heterogeneous hybrid rocks, aptly termed "migmatites." Evidence of cataclasis and recrystallization is abundant, and $\mathrm{K}$-feldspar appears to have been introduced into some samples after primary crystallization. Primary biotite is partially chloritized, but secondary biotite that crystallized in cataclastic zones generally is unaltered. Plagioclase is altered and locally recrystallized. These mineralogic reactions with essentially contemporaneous segregation of a felsic phase would facilitate migration of $\mathrm{Rb}$ and Sr. Biotite would release radiogenic Sr during this process, and introduced K-feldspar would effectively transport $\mathrm{Rb}$ and incorporate the mobile radiogenic $\mathrm{Sr}$ with the existing common $\mathrm{Sr}$ of the system. New biotite would also host any $\mathrm{Rb}$ that was released and acquire the new common Sr. Alteration of plagioclase would produce secondary minerals capable 
of acting as a sink for radiogenic $\mathrm{Sr}$ driven from the Rb-rich phases.

The apparent lack of participation of some samples of the gneiss at Watersmeet in this large-scale resetting of the $\mathrm{Rb}-\mathrm{Sr}$ systems cannot be explained with the available data. Sample D1395 has the highest $\mathrm{Sr}$ content among the samples of this gneiss, and possibly the gain in radiogenic $\mathrm{Sr}$ was buffered by the large component of common Sr. The same reasoning cannot be applied to D1394, however, because it has an intermediate $\mathrm{Sr}$ content.

Samples of the granite near Thayer are less disturbed than those from the Watersmeet body, and the data points plot close to the reference isochron of 2,600 m.y. D1043 is an exception, and its age has been lowered, probably as a result of severe cataclastic deformation. As mentioned earlier, these samples are from small, isolated bodies within garnet-grade Precambrian $\mathrm{X}$ bedded rocks (see fig. 1), and their field relationships are poorly known.

\section{CONCLUSIONS}

The $\mathrm{Rb} / \mathrm{Sr}$ data support the field relationships in indicating that the gneisses in the Watersmeet body are partly mobilized, reactivated basement rocks. The gneisses were formed at least 2,600 m.y. ago; approximately 1,800 m.y. ago, following deposition of the Marquette Range Supergroup, they were reactivated to form a gneiss dome mantled by the younger rocks. Reactivation of the gneisses was accompanied by strong internal dynamothermal metamorphism, which produced cataclasis and recrystallization, and also by metamorphic segregation and (or) partial melting, to yield the granitic fraction of the migmatites and probably the small bodies of granite and pegmatite within the body and in adjacent Precambrian $\mathrm{X}$ bedded rocks. Data are not adequate to determine whether some of the granitic material in the migmatites might be of an older $( \pm 2,600$ m.y.) age. Evidence from both the field relationships and the $\mathrm{Rb}-\mathrm{Sr}$ data, however, argues against large-scale partial melting during the reactivation, because large bodies of homogeneous granite of Precambrian $\mathrm{X}$ age are lacking and the granitic fraction of the migmatites is not strongly enriched in $\mathrm{Rb}$ and depleted in $\mathrm{Sr}$, as would be expected for anatectic granitic magmas derived at crustal levels.

The $\mathrm{Rb} / \mathrm{Sr}$ data for samples of the granite near Thayer (Fritts, 1969) indicate that these rocks also are Precambrian $W$ in age and are at least 2,600 m.y. old. Furthermore, the data are consistent with observations that these rocks were not so intensely deformed cataclastically and so thoroughly recrystallized as the gneisses in the Watersmeet body. Neither the field nor analytical data are adequate, however, to determine the extent to which the rocks were reactivated in Precambrian $\mathrm{X}$ time.

Judged from the $\mathrm{Rb}-\mathrm{Sr}$ data on samples of the Presque Isle Granite, the granite was only moderately disturbed during reactivation of this body in Precambrian X time. Except for the development of some pegmatite, there is scant evidence of mobility. Apparently, tectonic reconstitution of this body took place under essentially nonmetamorphic conditions (Watson, 1967). The mechanism of differential uplift may have been similar to that proposed by Cannon (1973) and, earlier, by James and others (1961) for the basement gneisses in the central part of northern Michigan.

Tectonic reconstitution of the gneiss at Watersmeet and perhaps also the granite near Thayer, on the other hand, was associated with internal metamorphism and migmatization. Accordingly, these bodies were relatively more plastic than the Presque Isle Granite during their rejuvenation, and possibly the gneiss at Watersmeet was emplaced in the manner of classic mantled gneiss domes (Eskola, 1949).

In general, the relative degree of mobility of the gneisses, as indicated by the $\mathrm{Rb}$-Sr systematics, correlates with the regional metamorphic zoning pattern in the Precambrian $\mathrm{X}$ bedded rocks. As shown on figure 1, the metamorphic grade of the bedded rocks increases toward the Watersmeet body, and both that body and the small bodies mapped as granite near Thayer by Fritts (1969) lie within the garnet isograd. Samples of the gneiss at Watersmeet are the most disturbed of the analyzed samples and register the effects of a severe dynamothermal metamorphism at about 1,800 m.y. ago. Samples of the granite near Thayer are disturbed but apparently less so than those of the gneiss at Watersmeet. On the other hand, the granitic facies of the Presque Isle Granite, which is surrounded by Precambrian $\mathrm{X}$ rocks of biotite grade or lower, has retained a Precambrian $W$ age, although it shows some effects of superposed events. These relationships suggest that the metamorphism in this region may be directly related to reactivation of the gneisses-a topic that deserves further study.

\section{REFERENCES CITED}

Abbott, J. T., 1972, Rb-Sr study of isotopic redistribution in a Precambrian mylonite-bearing shear zone, northern Front Range, Colorado: Geol. Soc. America Bull., v. 83, p. 487494.

Aldrich, L. T., Davis, G. L., and James, H. L., 1965, Ages of minerals from metamorphic and igneous rocks near Iron Mountain, Michigan : Jour. Petrology, v. 6, pt. 3, p. 445-472. 
Allen, R. C., and Barrett, L. P., 1915, Contributions to the preCambrian geology of northern Michigan and Wisconsin: Michigan Geol. Survey Pub. 18, Geol. Ser. 15, p. 13-164.

Atwater, G. I., 1938, Correlation of the Tyler and the Copps formations of the Gogebic iron district: Geol. Soc. America Bull., v. 49, p. 151-194.

Brooks, Christopher, 1968, Relationship between feldspar alteration and the precise post-crystallization movement of rubidium and strontium isotopes in a granite: Jour. Geophys. Research, v. 73, p. 4751-4757.

Cannon, W. F., 1973, The Penokean orogeny in northern Michigan: Geol. Assoc. Canada Spec. Paper 12, p. 251-271.

Cannon, W. F., and Gair, J. E., 1970, A revision of stratigraphic nomenclature for middle Precambrian rocks in northern Michigan: Geol. Soc. America Bull., v. 81, p. 2843-2846.

Cannon, W. F., and Simmons, G. C., 1973, Geology of part of the southern complex, Marquette district, Michigan: U.S. Geol. Survey Jour. Research, v. 1, no. 2, p. 165-172.

Eskola, P. E., 1949, The problem of mantled gneiss domes: Geol. Soc. London Quart. Jour., v. CIV, pt. 4, p. 461-476.

Fritts, C. E., 1969, Bedrock geologic map of the MareniscoWatersmeet area, Gogebic and Ontonagon Counties, Michigan: U.S. Geol. Survey Misc. Geol. Inv. Map I-576.

Gair, J. E., and Thaden, R. E., 1968, Geology of the Marquette and Sands quadrangles, Marquette County, Michigan: U.S. Geol. Survey Prof. Paper 397, 77 p.

Gorokhov, I. M., Varshavskaya, E. S., Kutyavin, E. P., and Lobach-Zhuchenko, S. B., 1970, Preliminary Rb-Sr geochronology of the North Ladoga Region, Soviet Karelia : Eclogae Geol. Helvetia, v. 63/1, p. 95-104.

Grauert, B., Hänny, R., and Soptrajanova, Gorica, 1974, Geochronology of a polymetamorphic and anatectic gneiss region-The Moldanubicum of the area Lam-Deggendorf, eastern Bavaria, Germany : Contr. Mineralogy and Petrology, v. 45, p. 37-63.

Hanson, G. N., Grünenfelder, Marc, and Soptrayanova, Gorica, 1969, The geochronology of a recrystallized tectonite in Switzerland-the Roffna Gneiss: Earth and Planetary Sci. Letters, v. 5, p. 413-422.

Hedge, C. E., 1972, Source of leucosomes of migmatites in the Front Range, Colorado, in Studies in mineralogy and Precambrian geology : Geol. Soc. America Mem. 135, p. 65-72.

Hunziker, J. C., 1970, Polymetamorphism in the Monte Rosa, Western Alps: Eclogae Geol. Helvetia, v. 63, p. 151-161.

James, H. L., 1955, Zones of regional metamorphism in the Precambrian of northern Michigan: Geol. Soc. America Bull., v. 66, no. 12, pt. 1, p. 1455-1487.
1958, Stratigraphy of pre-Keweenawan rocks in parts of northern Michigan: U.S. Geol. Survey Prof. Paper 314C, p. $27-44$.

James, H. L., Clark, L. D., Lamey, C. A., and Pettijohn, F. J., 1961, Geology of central Dickinson County, Michigan; U.S. Geol. Survey Prof. Paper 310, 176 p.

Klasner, J. S., and Cannon, W. F., 1974, Geologic interpretation of gravity profiles in the western Marquette district, northern Michigan: Geol. Soc. America Bull., v. 85, p. 213-218.

Krogh, T. E., and Davis, G. L., 1973, The effect of regional metamorphism on U-Pb systems in zircon and a comparison with $\mathrm{Rb}-\mathrm{Sr}$ systems in the same whole rock and its constituent minerals: Carnegie Inst. Washington Yearbook 72, p. 601-610.

Lanphere, M. A., Wasserburg, G. J., Albee, A. L., and Tilton, G. R., 1964, Redistribution of strontium and rubidium isotopes during metamorphism, World Beater complex, Panamint Range, California, in Isotopic and cosmic chemistry [Urey volume]: Amsterdam, North Holland Pub. Co., p. 269-320.

Peterman, Z. E., Doe, B. R., and Bartel, Ardith, 1967, Data on the rock GSP-1 (granodiorite) and the isotope-dilution method of analysis for $\mathrm{Rb}$ and $\mathrm{Sr}$, in Geological Survey research 1967: U.S. Geol. Survey Prof. Paper 575-B, p. B181-B186.

Pidgeon, R. T., and Compston, William, 1965, The age and origin of the Cooma Granite and its associated metamorphic zones, New South Wales: Jour. Petrology, v. 6, p. 193-222.

Prinz, W. C., 1967, Pre-Quaternary geologic and magnetic map and sections of part of the eastern Gogebic Range, Michigan: U.S. Geol. Survey Misc. Geol. Inv. Map I-497.

Trent, V. A., 1973, Geologic map of the Marenisco and Wakefield NE quadrangles, Gogebic County, Michigan: U.S. Geol. Survey open-file report.

Van Schmus, W. R., and Woosley, L. L., 1975, Rb-Sr geochronology of the Republic area, Marquette County, Michigan: Canadian Jour. Earth Sci., v. 12, p. 1723-1733.

Watson, Janet, 1967, Evidence of mobility in reactivated basement complexes: Proc. Geol. Assoc. London, v. 78, pt. 1, p. 211-236.

York, Derek, 1969, Least-squares fitting of a straight line with correlated errors: Earth and Planetary Sci. Letters, v. 5, p. 320-324.

Zartman, R. E., and Stern, T. W., 1967, Isotopic age and geologic relationships of the Little Elk Granite, northern Black Hills, South Dakota, in Geological Survey research 1967: U.S. Geol. Survey Prof. Paper 575-D, p. D157D163. 


\title{
FISSION-TRACK AGES OF SPHENE AND APATITE OF GRANITIC ROCKS OF THE SALINIAN BLOCK, COAST RANGES, CALIFORNIA
}

\author{
By C. W. NAESER and D. C. ROSS \\ Denver, Colo., Menlo Park, Calif.
}

\begin{abstract}
Fission-track ages have been determined on apatite and sphene from granitic rocks of the Salinian block, California Coast Ranges. The 26 age determinations on sphene range between 68 and $93 \mathrm{~m}$.y. The 24 age determinations on apatite have a greater variation, ranging from 3 to $74 \mathrm{~m} . \mathrm{y}$. None of the fission-track ages appear to reflect times of intrusion. The Pinnacles volcanic field of Miocene age apparently has thermally affected apatite ages in the central Gabilan and eastern Santa Lucia Ranges. Reduced apatite ages in the area between the Farallon Islands and the Monterey Peninsula may also be the result of Miocene volcanic activity, but the evidence is less conclusive. Fission-track ages on sphene correlate closely with previously determined potassium-argon ages on hornblende and biotite but show an unexplained "bimodal" age distribution, the ages in the Gabilan and Santa Lucia Ranges being slightly, but consistently, lower (avg 75 m.y.) than the ages for terrane to the north and south (avg 85 m.y.) The overall pattern of the sphene and apatite flssion-track ages, distinctly different from that of the central Sierra Nevada, may be a "fingerprint" of correlative value in locating the parent terrane of the "ripped-off" Salinian block.
\end{abstract}

Fission-track ages were determined on apatite and sphene from granitic rocks of the Salinian block, California Coast Ranges, to supplement earlier radiometric age studies by the potassium-argon and rubidiumstrontium methods. Studies of biotite and hornblende in these granitic rocks by the K-Ar method (Curtis and others, 1958; Huffman, 1972) gave ages ranging from 70 to 90 m.y. It has not been possible to distinguish or separate plutonic formations on the basis of these age determinations (Huffman, 1972). Rb-Sr determinations by R. W. Kistler (in Ross, 1972a) on nine samples of granitic rocks (six from the Gabilan Range and three from the Santa Lucia Range) give a $\mathrm{Rb}: \mathrm{Sr}$ isochron of $109 \pm 5$ m.y. A "non-isotopic" thorium-lead determination by Hutton $(1959$, p. 20$)$ on monazite from beach sands presumably derived from the granitic rock that underlies Monterey Peninsula gave an age of 106 m.y.

It appears, then, that the biotite and hornblende $\mathrm{K}$ Ar ages are not the age of crystallization of these rocks, but rather reflect a subsequent event. The simi- larity of biotite and hornblende ages throughout the Salinian block granitic terrane suggests a widespread and pervasive postintrusive event. Compton (1966, p. 287) suggested the K-Ar ages of Curtis, Evernden, and Lipson (1958) represent a "postgranite event," pointing up the difficulty of having granitic rocks in the Santa Lucia Range with K-Ar ages of about 70 m.y. overlain by Upper Cretaceous sedimentary rocks containing Campanian fossils. Dodge and Ross (1971, p. 166-168) observed that biotite and hornblende in the granitic rocks of the Salinian block may be in part recrystallized and that the $\mathrm{K}$-Ar ages may record this episode of recrystallization subsequent to emplacement.

With this background of radiometric data, it was thought that fission-track dating might help unravel the postintrusive thermal history of the granitic rocks. Fission-track age determinations were made on 26 sphene and 24 apatite separates from granitic rocks taken from localities shown in figure 1. As suspected, the postintrusive event (or events) that reduced the biotite and hornblende $\mathrm{K}$-Ar ages seems to be reflected in the fission-track ages of the sphene. These three minerals have similar spans of radiometric ages for the entire Salinian block (fig. 2). Apatite, more temperature-sensitive than sphene, gives a wider range of younger ages.

Acknowledgments.-We wish to thank R. R. Compton for the loan and use of his sample (15-206-4B) from the Santa Lucia Range.

\section{METHODS}

Apatite was dated by the method described by Naeser (1967) whereby a group of grains (about 100) were mounted and etched for fossil tracks, $25 \mathrm{~s}$ in 7 percent $\mathrm{HNO}_{3}$ at $25^{\circ} \mathrm{C}$. A second group was annealed $12 \mathrm{~h}$ at $500^{\circ} \mathrm{C}$, then sent to the reactor for thermal neutron irradiation for determination of induced track density. The neutron dosage was determined by placing a cali- 


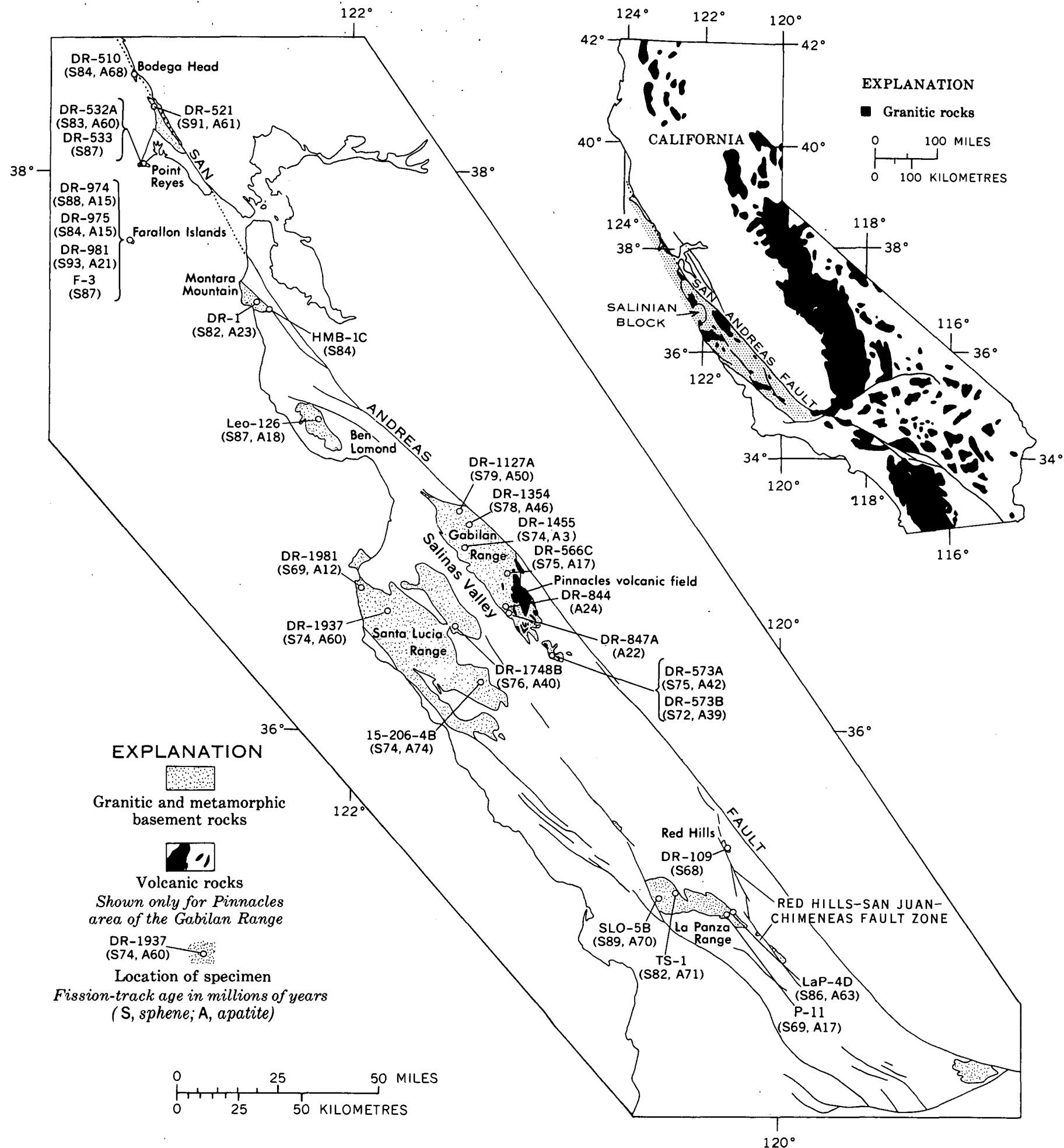

Figure 1.-Map showing location of samples of granitic rocks of the Salinian block, Coast Ranges, Calif., selected for flssiontrack age determinations on sphene and apatite, and index map showing granitic rocks of California and location of the Salinian block.

brated glass in the irradiation package with the samples. Fossil tracks in sphene were etched in $50 \mathrm{M}$ $\mathrm{NaOH}$ at $130^{\circ} \mathrm{C}$ for about $30 \mathrm{~min}$. Induced tracks were recorded in pieces of muscovite that had been placed over the sphene during irradiation, then etched in 45 percent $\mathrm{HF}$ at $25^{\circ} \mathrm{C}$ for $11 \mathrm{~min}$. 


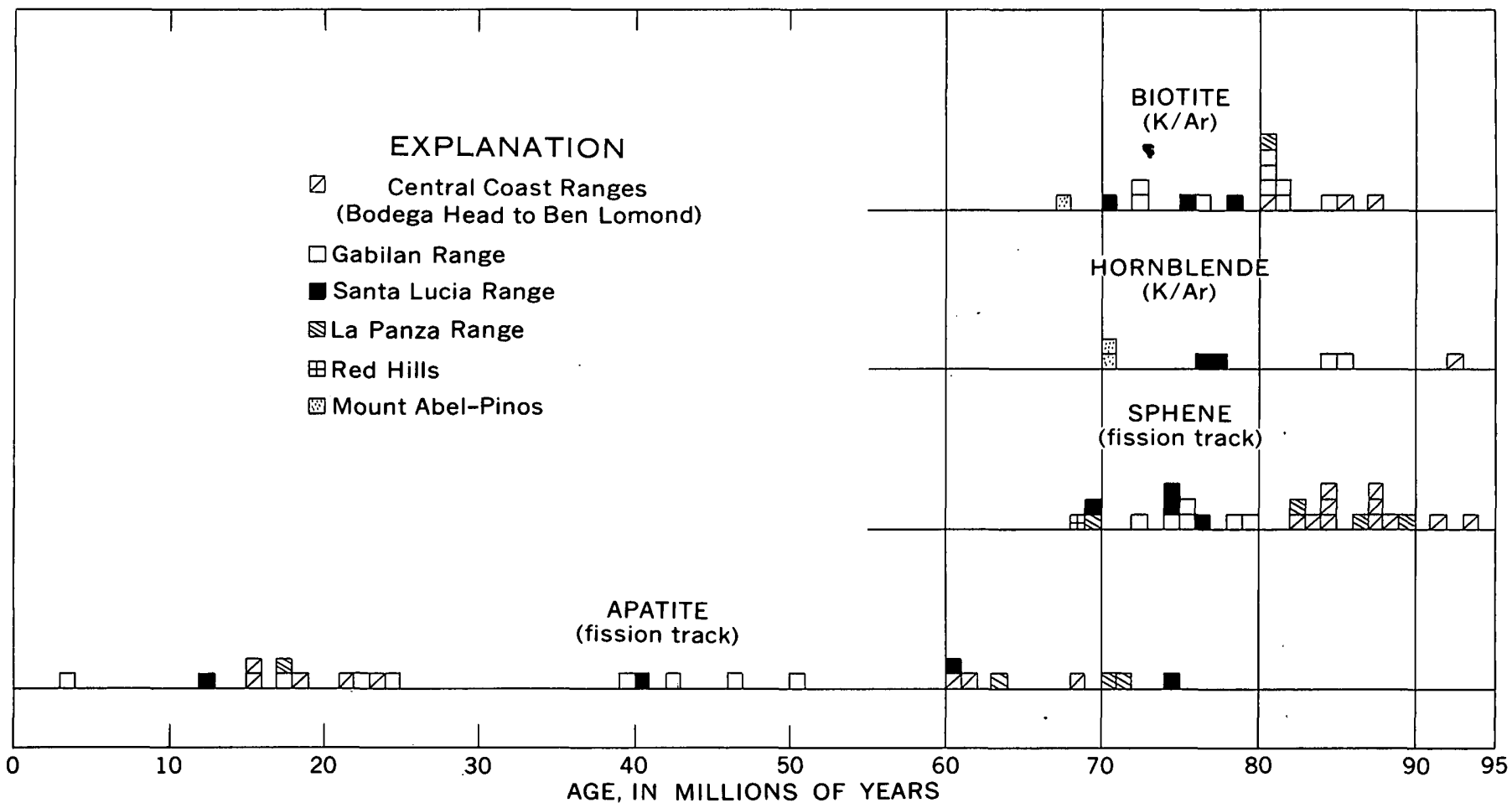

Fraure 2.-Radiometric age determinations in the Salinian block. Each small block equals one determination. Sphene and apatite data from tables 1 and 2 of this report; biotite and hornblende data from Compton (1966), Curtis, Evernden, and Lipson (1958), Evernden and Kistler (1970), and Huffman (1972).

\section{INTERPRETATION OF RESULTS}

\section{Sphene}

The sphene ages range from 68 to 93 m.y. and average 80 m.y. (table 1). The ages span the time interval rather "smoothly," showing no age peaks (fig. 2). The age range is closely coincident with the potassiumargon ages of hornblende and biotite from the Salinian block, showing that these three minerals had the same sensitivity to a postintrusive event.

A rather subtle, but distinct "bimodal" age distribution seems to exist in the sphene data: all the ages in the Gabilan and Santa Lucia Ranges are lower than 80 m.y., and the ages for Bodega Head to Ben Lomond to the north and the ages for the La Panza Range to the south are higher than 80 m.y. (fig. 3). Only two exceptions exist, an age of 68 m.y. for the Red Hills and one of 69 m.y. for the La Panza Range: the Red Hills sample (DR-109) at 68 m.y. is anomalously low, but its occurrence is east of the Red Hills-San Juan-Chimeneas fault zone (fig. 1) in a block thought to be structurally dislocated with respect to the main part of the Salinian block to the west (Ross, 1972b). For the anomalously low age of 69 m.y. for sample P-11 in the La Panza Range, no explanation is apparent. It may be noteworthy that this sample has a much lower apatite age than the other samples in the La Panza Range.
TABLE 1.-Sphene flssion-track ages $\left[\rho_{s}\right.$, fossll-track density in tracks $/ \mathrm{cm}^{2} ; \rho_{s}$, induced-track density in
tracks $/ \mathrm{cm}^{2} ; \phi$, neutrons $/ \mathrm{cm}^{2} ;$ and decay constant $\left.\lambda_{f}, 6.85 \times 10^{-17} \mathrm{yr}^{-1}\right]$

$\begin{array}{cl}\text { Sample } & \begin{array}{l}\text { Number } \\ \text { of fossil } \\ \text { counts }\end{array} \quad \rho s \quad \begin{array}{l}\text { Number } \\ \text { of Induced } \\ \text { counts }\end{array} \quad 1 / 2 \rho s \\ \text { Central Coast Ranges }\end{array}$

\begin{tabular}{|c|c|c|c|c|c|c|c|c|c|}
\hline $\begin{array}{l}-510 \\
-521 \\
-532 \mathrm{~A} \\
-533 \\
-974 \\
-975 \\
-9 \overline{5}- \\
\mathrm{B}-1 \mathrm{C} \\
-1 \\
-12 \mathrm{C}\end{array}$ & $\begin{array}{l}1, \\
1, \\
1, \\
1,\end{array}$ & $\begin{array}{l}6 . \\
1 . \\
1 .\end{array}$ & & $\begin{array}{l}1,1 \\
1.2\end{array}$ & & & & & \\
\hline
\end{tabular}

Gabilan Range

\begin{tabular}{|c|c|c|c|c|c|c|c|c|}
\hline $\begin{array}{l}\text { DR-566C } \\
\text { DR-573A } \\
\text { DR-573B } \\
\text { DR-1127A } \\
\text { DR-1354 } \\
\text { DR-1455 }\end{array}$ & $\begin{array}{l}1,677 \\
1,087 \\
1,056 \\
1,384 \\
1,014 \\
1,851\end{array}$ & $\begin{array}{r}1.50 \times 10^{7} \\
.652 \times 10^{7} \\
.724 \times 10^{7} \\
1.66 \times 10^{7} \\
.608 \times 10^{7} \\
1.67 \times 10^{7}\end{array}$ & $\begin{array}{r}1,550 \\
921 \\
785 \\
1,028 \\
861 \\
1,605\end{array}$ & $\begin{array}{r}1.40 \\
.55 \\
.53 \\
1.23 \\
.51 \\
1.44\end{array}$ & $\begin{array}{r}\times 10^{7} \\
\times 10^{7} \\
8 \times 10^{7} \\
\times 10^{7} \\
\times 10^{7} \\
\times 10^{7}\end{array}$ & $\begin{array}{l}2.26 \\
2.09 \\
1.76 \\
1.93 \\
2.18 \\
2.10\end{array}$ & $\begin{array}{l}74.6 \\
75.2 \\
72.2 \\
79.2 \\
78.2 \\
73.8\end{array}$ & $\begin{array}{l}5.3 \\
6.8 \\
6.8 \\
6.5 \\
7.3 \\
5.0\end{array}$ \\
\hline \multicolumn{9}{|c|}{ Santa Lucia Range } \\
\hline $\begin{array}{ll}\mathrm{DR}-1981 & - \\
\mathrm{DR}-1937 & - \\
\mathrm{DR}-1748 \mathrm{~B} & -- \\
15-206-4 B & =-\end{array}$ & $\begin{array}{l}2,226 \\
1,451 \\
1,202 \\
1,415\end{array}$ & $\begin{array}{r}13.4 \\
5.08 \times 10^{6} \\
5.77 \times 10^{\circ} \\
8.48 \times 10^{\circ} \\
\times 10^{\circ}\end{array}$ & $\begin{array}{r}1,073 \\
596 \\
\mathbf{5 3 6} \\
628\end{array}$ & $\begin{array}{l}6.45 \\
2.39 \\
2.58 \\
3.73\end{array}$ & $\begin{array}{r}\times 10^{6} \\
\times 10^{6} \\
\times 10^{6} \\
\times 10^{6}\end{array}$ & $\begin{array}{l}1.09 \\
0.99 \\
1.11 \\
1.08\end{array}$ & $\begin{array}{l}69.0 \\
73.5 \\
75.8 \\
74.2\end{array}$ & $\begin{array}{l}5.1 \\
7.2 \\
7.9 \\
7.1\end{array}$ \\
\hline \multicolumn{9}{|c|}{ La Panza Range } \\
\hline $\begin{array}{l}\text { TS-11 } \\
\text { P-1:1 } \\
\text { SLO-5B } \\
\text { LaP-4D }\end{array}$ & $\begin{array}{r}331 \\
1,412 \\
1,732 \\
1,212\end{array}$ & $\begin{array}{l}7.94 \times 10^{6} \\
8.47 \times 10^{8} \\
6.93 \times 10^{8} \\
5.82 \times 10^{\circ}\end{array}$ & $\begin{array}{l}137 \\
624 \\
629 \\
440\end{array}$ & $\begin{array}{l}3.29 \\
3.75 \\
2.52 \\
2.11\end{array}$ & $\begin{array}{r}\times 10^{6} \\
\times 10^{\circ} \\
\times 10^{0} \\
\times 10^{\circ}\end{array}$ & $\begin{array}{l}1.12 \\
1.00 \\
1.06 \\
1.02\end{array}$ & $\begin{array}{l}82.0 \\
69.0 \\
88.9 \\
85.6\end{array}$ & $\begin{array}{r}16.0 \\
6.6 \\
8.3 \\
8.5\end{array}$ \\
\hline \multicolumn{9}{|c|}{ Red Hills } \\
\hline DR-109 & 696 & $1.36 \times 10^{7}$ & 1,640 & .31 & $10^{7}$ & 2.14 & 7.5 & 4.7 \\
\hline
\end{tabular}

1 Only one grain suitable for dating. 


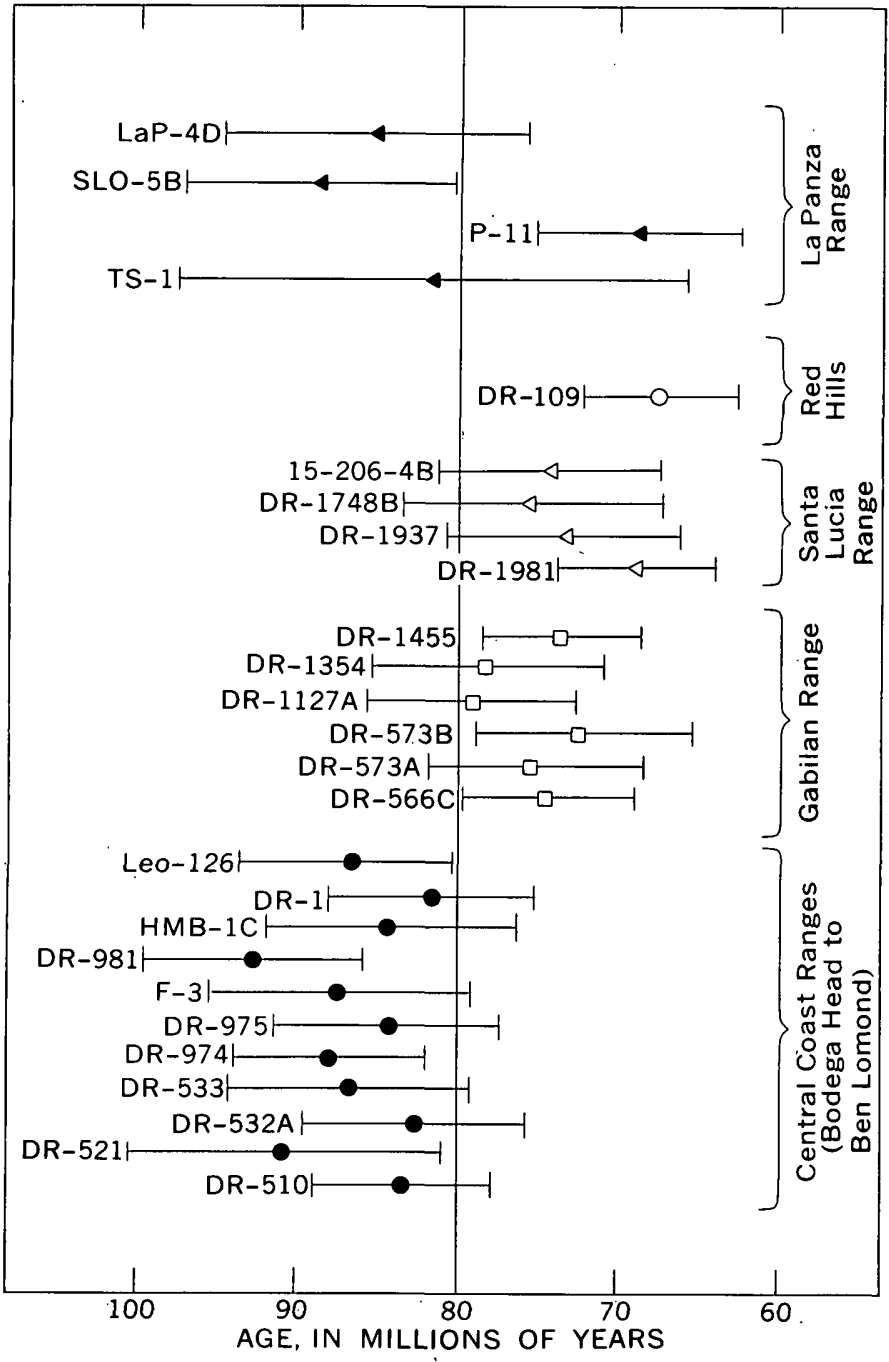

Fraure 3.-Fission-track ages of sphene showing "bimodal" age distribution. Bar shows uncertainty of age, $\pm 2 \sigma$ values of table 1 .

The two groups of ages measured on sphene do overlap if the uncertainty bars are considered, although the number of data points is admittedly small. The geographic distribution suggests that the difference is real and that there must be some reason for the somewhat "younger" age of the sphenes of the Gabilan and Santa Lucia Ranges relative to the rest of the Salinian block. Speculation suggests that the Gabilan and Santa Lucia Ranges were uplifted through the isotherm that allowed the sphene clock to start somewhat later than the region to the north and south. The greater abundance of high-grade metamorphic rocks at this latitude relative to the rest of the Salinian block may somehow be related to the same event.

The sphene ages provide one more bit of evidence to favor the Santa Lucia and Gabilan Ranges being structurally tied together, rather than, as previously pro- posed, separated by a major basement structural break along Salinas Valley (Ross, 1972b; Ross and Brabb, 1973).

\section{Apatite}

The apatite ages (table 2) show a range from 3 to 74 m.y. and can be grossly divided into three groups (fig. 2) : an older group, ranging from 60 to 74 m.y., that overlaps the lower part of the sphene age span; an intermediate age group that falls between 39 and 50 m.y.; and a younger group that ranges from 12 to 24 m.y. An exception to this grouping is a sample from the Gabilan Range, dated at 3 m.y. (DR-1455), that was subjected to a very young, and so far unexplained, thermal event.

TABLE 2.-Apatite fission-track ages

$\left[\rho\right.$, fossil-track density in tracks $/ \mathrm{cm}^{2}$; $\rho$, induced-track density in tracks $/ \mathrm{cm}^{2} ; \phi$, neutrons $/ \mathrm{cm}^{2} ;$ and decay constant $\left.\lambda_{f}, 6.85 \times 10^{-17} \mathrm{yr}^{-1}\right]$

\begin{tabular}{|c|c|c|c|c|c|c|c|}
\hline Sample & $\begin{array}{c}\text { Num- } \\
\text { ber } \\
\text { of } \\
\text { fossil } \\
\text { counts }\end{array}$ & ( $\left.\times^{\rho} \mathbf{1 0}^{\mathbf{1}}\right)$ & $\begin{array}{c}\text { Num- } \\
\text { ber } \\
\text { of } \\
\text { induced } \\
\text { counts }\end{array}$ & $\left(x^{\rho} 10^{5}\right)$ & $\left(\times^{\phi} 0^{15}\right)$ & $\begin{array}{c}\text { Age } \\
\text { (m.y.) }\end{array}$ & $\pm 2 \sigma$ \\
\hline \multicolumn{8}{|c|}{ Central Coast Ranges } \\
\hline $\begin{array}{l}\text { DR-510 }---- \\
\text { DR-521 } \\
\text { DR-532A }--- \\
\text { DR-981 }=-- \\
\text { DR-974 } \\
\text { DR-975 }=-- \\
\text { DR-1 } \\
\text { Leo-126 }---- \\
\end{array}$ & \begin{tabular}{r|}
$\mathbf{1}, 956$ \\
$\mathbf{2}, \mathbf{2 3 3}$ \\
$\mathbf{1 , 1 2 3}$ \\
$\mathbf{2 2 9}$ \\
$\mathbf{1 4 9}$ \\
$\mathbf{1 4 6}$ \\
$\mathbf{1 , 0 6 6}$ \\
$\mathbf{4 9 3}$
\end{tabular} & $\begin{array}{l}2.11 \\
1.07 \\
.54 \\
.11 \\
.072 \\
.070 \\
1.15 \\
.53\end{array}$ & $\begin{array}{r}1,793 \\
2.405 \\
1,242 \\
674 \\
674 \\
641 \\
\mathbf{6 4 1 3} \\
\mathbf{1 , 9 1 3} \\
\mathbf{1 , 7 7 4}\end{array}$ & \begin{tabular}{r|}
1.94 \\
1.15 \\
.60 \\
.32 \\
.32 \\
.31 \\
3.15 \\
1.92
\end{tabular} & $\begin{array}{l}1.03 \\
1.08 \\
1.08 \\
1.03 \\
1.08 \\
1.06 \\
1.03 \\
1.03\end{array}$ & $\begin{array}{l}68.4 \\
60.9 \\
59.6 \\
21.4 \\
14.6 \\
14.8 \\
23.1 \\
17.5\end{array}$ & $\begin{array}{l}8.3 \\
9.7 \\
6.0 \\
4.2 \\
3.2 \\
3.4 \\
4.7 \\
3.8\end{array}$ \\
\hline \multicolumn{8}{|c|}{ Gabilan Range } \\
\hline $\begin{array}{l}\text { DR-566C }--- \\
\text { DR-573A }=- \\
\text { DR-573B }=- \\
\text { DR-844 }--- \\
\text { DR-847A } \\
\text { DR }-11274=- \\
\text { DR-1354 }=- \\
\text { DR-1455 }=-\end{array}$ & $\begin{array}{r}954 \\
867 \\
863 \\
225 \\
155 \\
2,301 \\
1,256 \\
40\end{array}$ & $\begin{array}{l}0.46 \\
.42 \\
.41 \\
.11 \\
.074 \\
1.11 \\
1.36 \\
.0043\end{array}$ & $\begin{array}{r}3,754 \\
1,293 \\
1,394 \\
614 \\
442 \\
2,978 \\
1,764 \\
935\end{array}$ & $\begin{array}{r}1.80 \\
.62 \\
.67 \\
.29 \\
.21 \\
1.43 \\
1.91 \\
1.01\end{array}$ & $\begin{array}{l}1.07 \\
1.03 \\
1.03 \\
1.08 \\
1.03 \\
1.05 \\
1.05 \\
1.06\end{array}$ & $\begin{array}{r}16.7 \\
42.2 \\
39.0 \\
24.2 \\
22.1 \\
49.6 \\
45.7 \\
2.8\end{array}$ & $\begin{array}{r}4.6 \\
5.1 \\
9.4 \\
3.5 \\
6.6 \\
8.1 \\
12.3 \\
\quad .9\end{array}$ \\
\hline \multicolumn{8}{|c|}{ Santa Lucia Range } \\
\hline $\begin{array}{l}\mathrm{DR}-1981 \\
\mathrm{DR}-1937 \\
\mathrm{DR}-1748 \mathrm{~B}=- \\
15-206-4 \mathrm{~B}=-\end{array}$ & $\begin{array}{r}305 \\
759 \\
756 \\
1,462\end{array}$ & $\begin{array}{l}1.46 \\
3.64 \\
3.63 \\
7.02\end{array}$ & $\begin{aligned} 1,701 \\
833 \\
1,276 \\
1,311\end{aligned}$ & $\begin{array}{l}8.16 \\
4.00 \\
6.12 \\
6.29\end{array}$ & $\begin{array}{l}1.08 \\
1.08 \\
1.09 \\
1.09\end{array}$ & $\begin{array}{l}12.0 \\
60.0 \\
39.5 \\
74.0\end{array}$ & $\begin{array}{r}2.4 \\
12.0 \\
8.0 \\
14.0\end{array}$ \\
\hline \multicolumn{8}{|c|}{ La Panza Range } \\
\hline $\begin{array}{l}\text { TS-1 } \\
\text { P-11 } \\
\text { SLO----- } \\
\text { LaP-4D }=- \\
\text { LaP }=-\end{array}$ & $\begin{array}{r}1,285 \\
376 \\
991 \\
390\end{array}$ & $\begin{array}{l}6.17 \\
1.80 \\
4.76 \\
1.87\end{array}$ & $\begin{array}{r}1,192 \\
1,424 \\
940 \\
411\end{array}$ & $\begin{array}{l}5.72 \\
6.84 \\
4.51 \\
1.97\end{array}$ & $\begin{array}{l}1.08 \\
1.07 \\
1.09 \\
1.08\end{array}$ & $\begin{array}{l}71.0 \\
17.3 \\
70.1 \\
62.6\end{array}$ & $\begin{array}{r}14.0 \\
3.4 \\
14.0 \\
13.0\end{array}$ \\
\hline
\end{tabular}

The younger ages in the Gabilan Range $(24,22$, and 17 m.y.) were measured on samples located very close to the Pinnacles volcanic field (fig. 1). K-Ar ages of about 23 m.y. measured on these volcanic rocks by Turner and others (1970) suggest that voloanic activity has caused the resetting of the apatite clock in this area. It is possibly significant that the dates of the intermediate group (39 to 50 m.y.) all are closely peripheral to the Pinnacles area, suggesting partial obliteration of the apatite fission tracks to yield an intermediate age. 
Calk and Naeser (1973) noted that a small isolated basalt intrusion into granitic rock reduced apatite fission-track ages possibly as far as $500 \mathrm{ft}$ from the intrusive contact, whereas sphene ages were unaffected as close to basalt as $30 \mathrm{ft}$. The volcanism at the Pinnacles might have had a much more widespread effect on the apatite fission-track ages in the surrounding granitic terrane, as an area of at least $10 \times 20 \mathrm{~km}$ is permeated by volcanic material.

Reduced apatite ages in the range of 12 to 23 m.y. are found on the Farallon Islands, at Montara Mountain, Ben Lomond, and at the north end of the Santa Lucia Range (fig. 1). Basaltic volcanic rocks of Miocene age are exposed in the Carmel area (Clark and others, 1974) within $4 \mathrm{~km}$ of the Santa Lucia occurrence (DR-1981). Rather extensive basaltic volcanic rocks exposed between Montara Mountain and Ben Lomond have been dated by the K-Ar method at about 20 m.y. (Turner, 1970, p. 99, Mindego Basalt), and Tertiary volcanic rocks have been dredged from the Pioneer and Mulberry seamounts about $50 \mathrm{~km}$ southwest of the Farallon Islands. The volcanic rocks now exposed probably represent only a small sample of the widespread volcanic rocks that were produced in this region in the Miocene, and it is at least suggestive that volcanic activity could have been the agent that reduced the apatite ages from the Farallon Islands south to the northern Santa Lucia Range.

The reduced apatite in the La Panza Range of 17 m.y. (P-11) is somewhat more difficult to explain, as there seems to be no local geologic cause for this anomaly: other apatites in the range yield values of 63 to 71 m.y. Possibly the sample is anomalous, for the sphene also is anomalously low, 69 m.y. compared with 82 to 89 m.y. for other samples in the La Panza Range.

Apatite is subject to the obliteration of its fission tracks at relatively low temperatures (of the order of $100^{\circ} \mathrm{C}$ over $10^{\circ} \mathrm{yr}$, Naeser and Faul, 1969). It is expectable therefore that the apatite ages are generally lower than the sphene ages (fig. 2). An exception of interest is a concordant sphene and apatite age of $\mathbf{7 4}$ m.y. in the Sagnta Lucia Range (15-206-4B), the only sample even close to concordance in the Salinian block.

\section{COMPARISON OF FISSION-TRACK AGES OF THE CENTRAL SIERRA NEVADA AND THE SALINIAN BLOCK}

A plot of 34 sphene and 44 apatite fission-track determinations by Naeser and Dodge (1969) on rocks from the central Sierra Nevada with the Salinian block ages (fig. 4) shows the range of sphene values to be somewhat comparable (70 to 100 m.y. for the Sierra Nevada and 70 to 90 m.y. for the Salinian block). One notable contrast is that some of the Sierran sphene ages probably reflect the actual intrusive ages of rocks that have undergone no later heating events strong enough to wipe out their tracks (some of the 80- to 90-m.y.-old units, Naeser and Dodge, 1969, p. 2203), whereas the sphene ages in the Salinian block all appear to be reset ages (based on Rb-Sr data, $\mathrm{R}$. W. Kistler in Ross, 1972a). Nevertheless, the general coincidence of sphene ages suggests that both terranes may have been similarly influenced by an intrusive event and (or) uplift 70 to 90 m.y. ago.

The more temperature-sensitive apatite ages present a much different pattern. The range of Sierran apatites in general compares closely with the Sierran sphene age

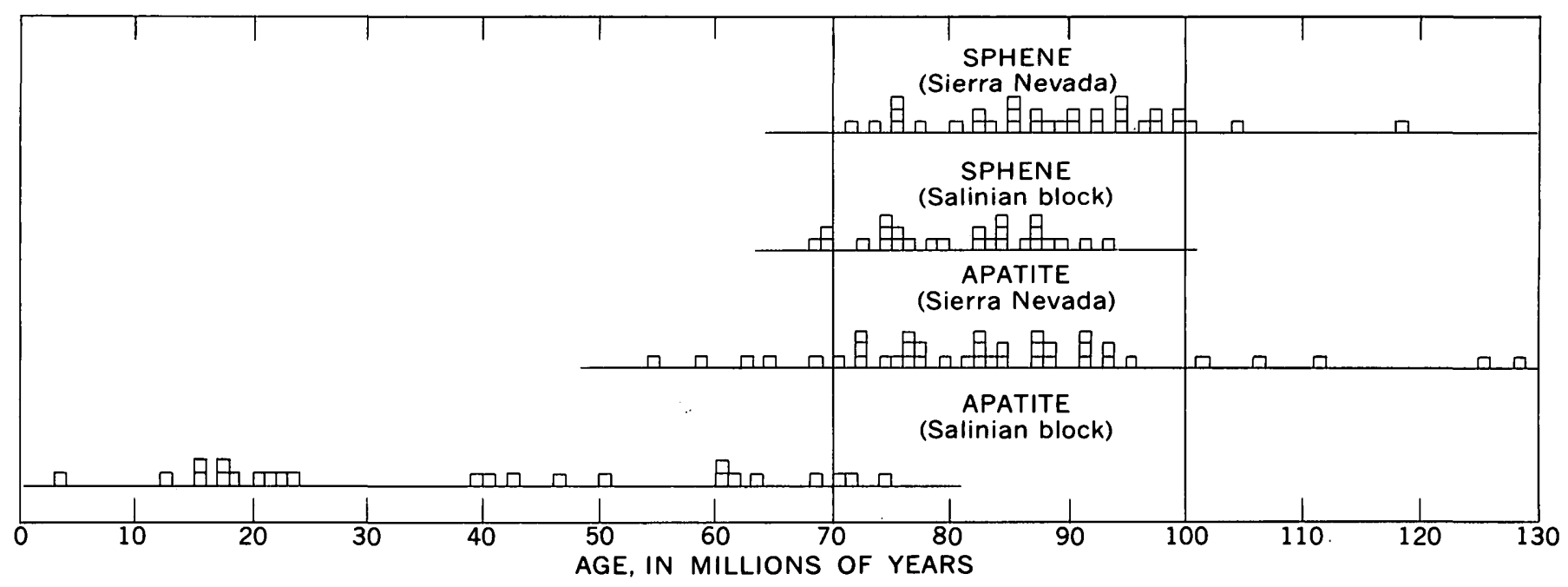

Frgure 4.-Comparison of fission-track ages of sphene and apatite for the Salinian block and the Sierra Nevada. Ages for Sierra Nevada from Naeser and Dodge (1969). 
range, and there are a number of near-concordant and concordant pairs of sphene and apatite ages in the Sierra Nevada (Naeser and Dodge, 1969, p. 2206). The overall picture is that most of the Sierran apatite ages are in the 70 to 90 m.y. range with minor dribbling off to values comparable to the oldest Salinian-block apatite ages, whereas the apatite ages are strongly "offset" from the sphene ages in the Salinian block. The Salinian block seems to have had a more active thermal history in the middle Tertiary than the Sierra Nevada.

The paucity of middle Tertiary volcanic rocks relative to the Salinian block in the part of the Sierra Nevada sampled by Naeser and Dodge (1969) may be at least part of the answer. This contrast in fissiontrack pattern between the central Sierra Nevada and the Salinian block supports the hypothesis that the Salinian block is a displaced basement block, not merely a westward extension of Sierra Nevada basement terrane.

\section{THE POSSIBLE CORRELATIVE VALUE OF THESE FISSION-TRACK AGE PATTERNS}

The pattern of fission-track ages for the apatite is probably produced at least in part by the distribution of Miocene volcanic rocks, a relation most evident around the Pinnacles volcanic field. Mathews (1973, p. 683) has noted that the Pinnacles volcanic field is probably correlative with distinctive Neenach volcanic rocks in the Transverse Ranges, and he has postulated that this once-contiguous volcanic field has been split and separated more than $300 \mathrm{~km}$ by right-lateral movement on the San Andreas fault. Along with the future study of the basement rock types of the Neenach area, it will be of value to see if a pattern of apatite fissiontrack ages exists there that can be matched with the reduced age pattern of the Gabilan and eastern Santa Lucia Ranges. The bimodal age distribution of the sphene ages (the "trough" in the Gabilan and Santa Lucia Ranges) can also be looked for in the Neenach area.

The presence or absence of these fission-track age patterns is probably not critical to regional correlations, for there can undoubtedly be many and varied reasons for the reduction of fission-track ages, particularly for the relatively temperature-sensitive apatite. Nevertheless, fission-track age patterns can supplement correlations based on the patterns of distribution of basement rock types.

\section{REFERENCES CITED}

Calk, L. C., and Naeser, C. W., 1973, The thermal effect of a basalt intrusion on fission tracks in quartz monzonite: Jour. Geology, v. 81, p. 189-198.
Clark, J. C., Dibblee, T. W., Jr., Greene, H. G., and Bowen, O. E., Jr., 1974, Preliminary geologic map of the Monterey and Seaside $71 / 2$-minute quadrangles, Monterey County, California, with emphasis on active faults: U.S. Geol. Survey Misc. Field Studies Map MF-577.

Compton, R. R., 1966, Granitic and metamorphic rocks of the Salinian block, California Coast Ranges, in Bailey, E. H., ed., Geology of northern California : California Div. Mines and Geology Bull. 190, p. 277-287.

Curtis, G. H., Evernden, J. F., and Lipson, J., 1958, Age determinations of some granitic rocks: California Div. Mines and Geology Spec. Rept. 54, $16 \mathrm{p}$.

Dodge, F. C. W., and Ross, D. C., 1971, Coexisting hornblendes and biotites from granitic rocks near the San Andreas fault, California: Jour. Geology, v. 79, p. 158-172.

Evernden, J. F., and Kistler, R. W., 1970, Chronology of emplacement of Mesozoic batholithic complexes in California and western Nevada: U.S. Geol. Survey Prof. Paper 623, $42 \mathrm{p}$.

Huffman, O. F., 1972, Lateral displacement of Upper Miocene rocks and the Neogene history of offset along the San Andreas fault in Central California: Geol. Soc. America Bull., v. 3, p. 2913-2946.

Hutton, C. O., 1959, Mineralogy of beach sands between Halfmoon and Monterey Bays, California: California Div. Mines Spec. Rept. 59, 32 p.

Mathews, Vincent, 3d, 1973, Pinnacles-Neenach Correlations : A restriction for models of the origin of the Transverse Ranges and the big bend in the San Andreas fault: Geol. Soc. America Bull., v. 84, p. 683-688.

Naeser, C. W., 1967, The use of apatite and sphene for fissiontrack age determinations: Geol. Soc. America Bull., v. 78, no. 12, p. 1523-1526.

Naeser, C. W., and Dodge, F. C. W., 1969, Fission-track ages of accessory minerals from granitic rocks of the central Sierra Nevada batholith, California: Geol. Soc. America Bull., v. 80, p. 2201-2212.

Naeser, C. W., and Faul, Henry, 1969, Fission-track annealing in apatite and sphene: Jour. Geophys. Research, v. 74, no. 2, p. 705-710.

Ross, D. C., 1972a, Geologic map of the Pre-Cenozoic basement rocks, Gabilan Range, Monterey and San Benito Counties, California : U.S. Geol. Survey Misc. Field Studies Map MF357.

Ross, D. C., 1972b, Petrographic and chemical reconnaissance study of some granitic and gneissic rocks near the San Andreas fault from Bodega Head to Cajon Pass, California : U.S. Geol. Survey Prof. Paper 698, 92 p.

Ross, D. C., and Brabb, E. E., 1973, Petrography and structural relations of granitic basement rocks in the Monterey Bay area, California: U.S. Geol. Survey Jour. Research, v. 1, no. 3, p. 273-282.

Turner, D. L., 1970, Potassium-argon dating of Pacific Coast Miocene foraminiferal stages: Geol. Soc. America Spec. Paper 124, p. 91-129.

Turner, D. L., Curtis, G. H., Berry, F. A. F., and Jack, R. N., 1970, Age relationship between the Pinnacles and Parkfield felsites and felsite clasts in the southern Temblor Range, California-implications for San Andreas fault displacement: Geol. Soc. America Abstracts with Programs, v. 2, no. 2, p. 154. 


\title{
REVISION OF THE CARBONIFEROUS GENUS AULINA SMITH (COELENTERATA, ANTHOZOA)
}

\author{
By WILLIAM J. SANDO, Washington, D.C.
}

\begin{abstract}
Morphologic and stratigraphic evidence bearing on the phylogenetic relationships of aulate Carboniferous corals suggests that species previously assigned to the genus Aulina Smith represent at least six different lineages that descended from three different ancestral genera. A classification designed to better reflect phylogenetic relationships includes the new genera Aulokoninckophyllum, Aulostylus, Solenodendron, and Vesiculotubus. The new North American taxa Aulostylus tubiferus tubiferus, $A$. tubiferus eotubiferus, and $A$. bamberi are described and illustrated. Two new Chinese species, Aulina (Pseudoaulina) $l o i$ and $A$. (P.) sinensis, are also proposed.
\end{abstract}

Corals having an aulos or axial tube are relatively rare in Paleozoic rocks and are particularly rare in rocks of Carboniferous age. Most of the aulate Carboniferous corals have been referred to the genus Aulina Smith, 1916, which also has carinate septa, another uncommon feature in Carboniferous corals. The biologic implication of such a classification is that the aulos is a unifying phylogenetic character and that all aulate species are closely related. Revision of the genus by Smith and Yü (1943) led to the conclusion that the species of Autina were derived polyphyletically from various species of Lithostrotion Fleming, one of the most common Carboniferous coral genera.

More recently, Minato and Rowett (1967) summarized existing knowledge of aulate Carboniferous corals and concluded that the group was in need of further taxonomic revision in order to distinguish the various lines of descent included in it. They proposed recognition of two subgenera to include "astraeoid" (thamnasterioid) and aphroid species. Although they also suggested that other generic, assignments for solitary and fasciculate species might be appropriate, they deferred action on these taxonomic questions.

A study of the type specimens of Hayasaka's (1936) North American species of Lithostrotionella led me to investigate the generic affinities of Lithostrotionella tubifera Hayasaka, an aulate coral that has been referred by some authors to Aulina. I concluded that $L$. tubifera is not closely related to Aulina s.s. and that it should be recognized as a new genus. Moreover, data on "Aulina" published since Minato and Rowett's (1967) study provide additional support for their general taxonomic conclusions. Accordingly, I recognize four new genera among the corals previously assigned to Aulina, in addition to Aulina s.s.

Phylogenetic relationships inferred from the morphology and stratigraphic distribution of the aulate Carboniferous corals are discussed in the systematic part of this report because such relationships are important to establishing the validity of the proposed genera. The stratigraphic ranges of the species considered are shown in figure 1. Imprecise knowledge of the stratigraphic positions of many species leaves considerable doubt concerning detailed relationships between some species. However, the presence of "linking species," which have some corallites that have the morphology of ancestral or descendant species, and evidence of morphologic trends within groups of species

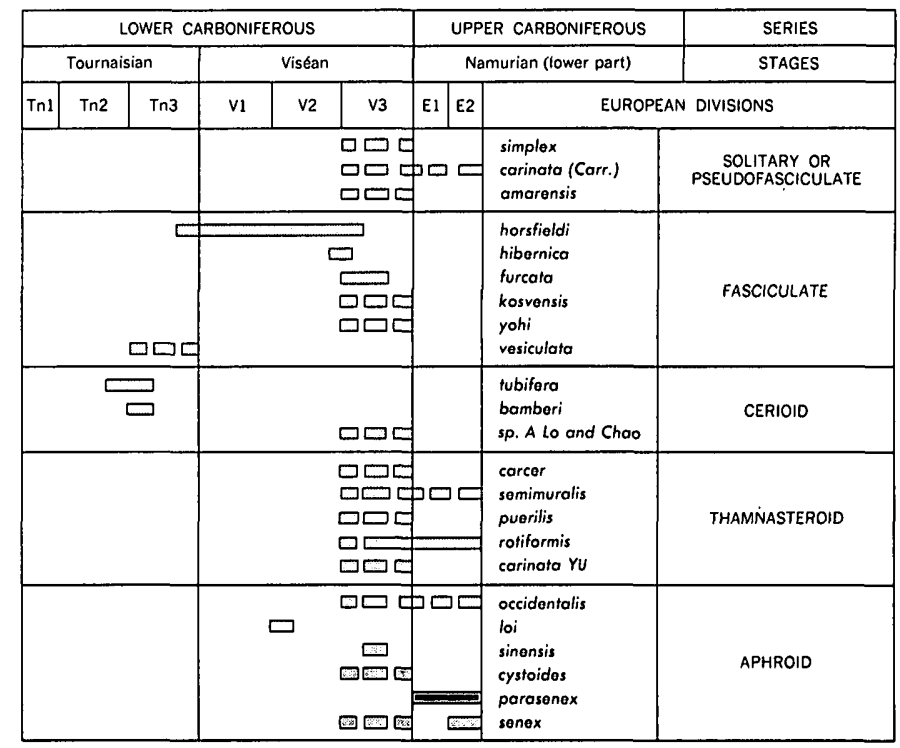

Figure 1.-Stratigraphic ranges of species that have been referred to Aulina. Dashed range lines indicate that precise range is uncertain within time-stratigraphic units shown. 
provide a reasonable basis for establishing the principal lines of descent in the aulate complex, when placed in a stratigraphic context. Inferred phylogenetic relationships (fig. 2) suggest that the five aulate genera recognized herein were derived independently from different genera or subgenera.

Acknowledgments.-I am indebted to E. W. Bamber for the opportunity to study Canadian material described herein. B. L. Mamet identified microfaunas associated with North American corals described. Thin sections were prepared by K. R. Moore. K. R. Moore, R. H. McKinney, and H. E. Mochizuki provided the photographs.

\section{SYSTEMATIC PALEONTOLOGY}

Morphologic terminology is generally that of Hill (1956, p. 234-251), except for microstructural elements (Kato, 1963). Familial concepts follow Hill (1956); new genera are placed in the same families as ancestral genera. Repositories for type specimens of North American species described are the U.S. Nation-

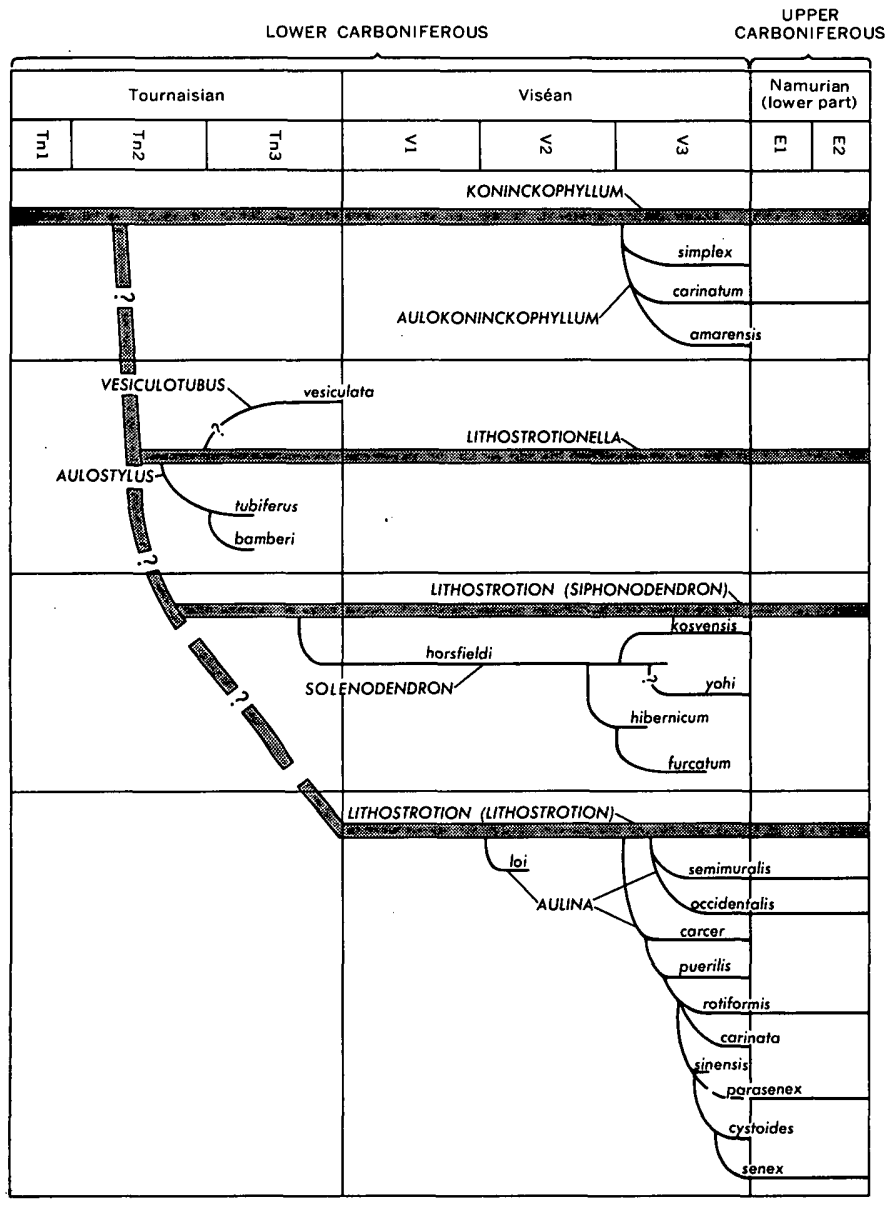

Figure 2.-Inferred phylogenetic relationships of the species of aulate Carboniferous corals. al Museum, Washington, D.C. (USNM), and the Geological Survey of Canada, Ottawa, Ontario (GSC). Locality numbers refer to the upper Paleozoic catalog of the U.S. Geological Survey (USGS) and the Carboniferous catalog of the Geological Survey of Canada (GSC).

Family LITHOSTROTIONIDAE d'Orbigny, 1851 Genus AULINA Smith, 1916, emend.

Type species.-Aulina rotiformis Smith, 1916, p. 2, 3 ; Smith, 1917, p. 290, text figs. 3 and 4 on p. 291 and 292, pl. 22, figs. 6-11.

Diagnosis.-Subcerioid, thamnasterioid, or aphroid aulate corals in which the aulos is formed by union of deflected axial ends of major septa. Major and minor septa ordinarily carinate; carinae of the zigzag type. Dissepimentarium regular or lonsdaleoid. Tabulae in aulos ordinarily flat, horizontal; tabulae in tabularium ordinarily concave upward or flat, and horizontal or sloping downward toward periphery of corallite. Offsets originate in common tissue between corallites. Microstructure unknown.

Occurrence.-Represented by 11 species. Middle Viséan (China); upper Viséan (England?, U.S.S.R., China, Japan) ; lower Namurian (England, Scotland, U.S.S.R.) ; upper Viséan or lower Namurian (U.S.A.).

Discussion.-Inferred phylogenetic relationships within this genus (fig. 3) are relatively clear insofar as most of its species are concerned. The thamnasterioid representatives (subgenus Aulina) are linked to the ancestral cerioid Lithostrotion (Lithostrotion) maccoyanum by $A$. (A.) carcer and $A$. (A.) semimuralis, which include subcerioid corallites and have a poorly developed aulos. $A$. (A.) carcer, $A$. (A.) pueritis, $A$. (A.) rotiformis, and $A$. (A.) carinata form a continuous phylogenetic sequence characterized by increasing septal number and aulos diameter.

The aphroid representatives (subgenus Pseudoaulina) seem to have been derived partly from thamnasterioid forms (subgenus Aulina) and partly directly from Lithostrotion (Lithostrotion). The subcerioid linking species $A$. (P.) occidentalis may have been derived from $A$. (A.) semimuralis or from an unknown species of Lithostrotion (Lithostrotion). A. (P.) loi, which has an imperfectly formed aulos and small aulos diameter, probably was derived directly from Lithostrotion (Lithostrotion) or from an unknown intermediate species of Pseudoaulina. A. (P.) sinensis links Pseudoaulina to $A$. (A.) rotiformis and leads to $A$. $(P$.$) cystoides, A$. (P.) parasenex, and $A$. (P.) senex by increase in septal number and aulos diameter and decrease in perfection of the aulos. 


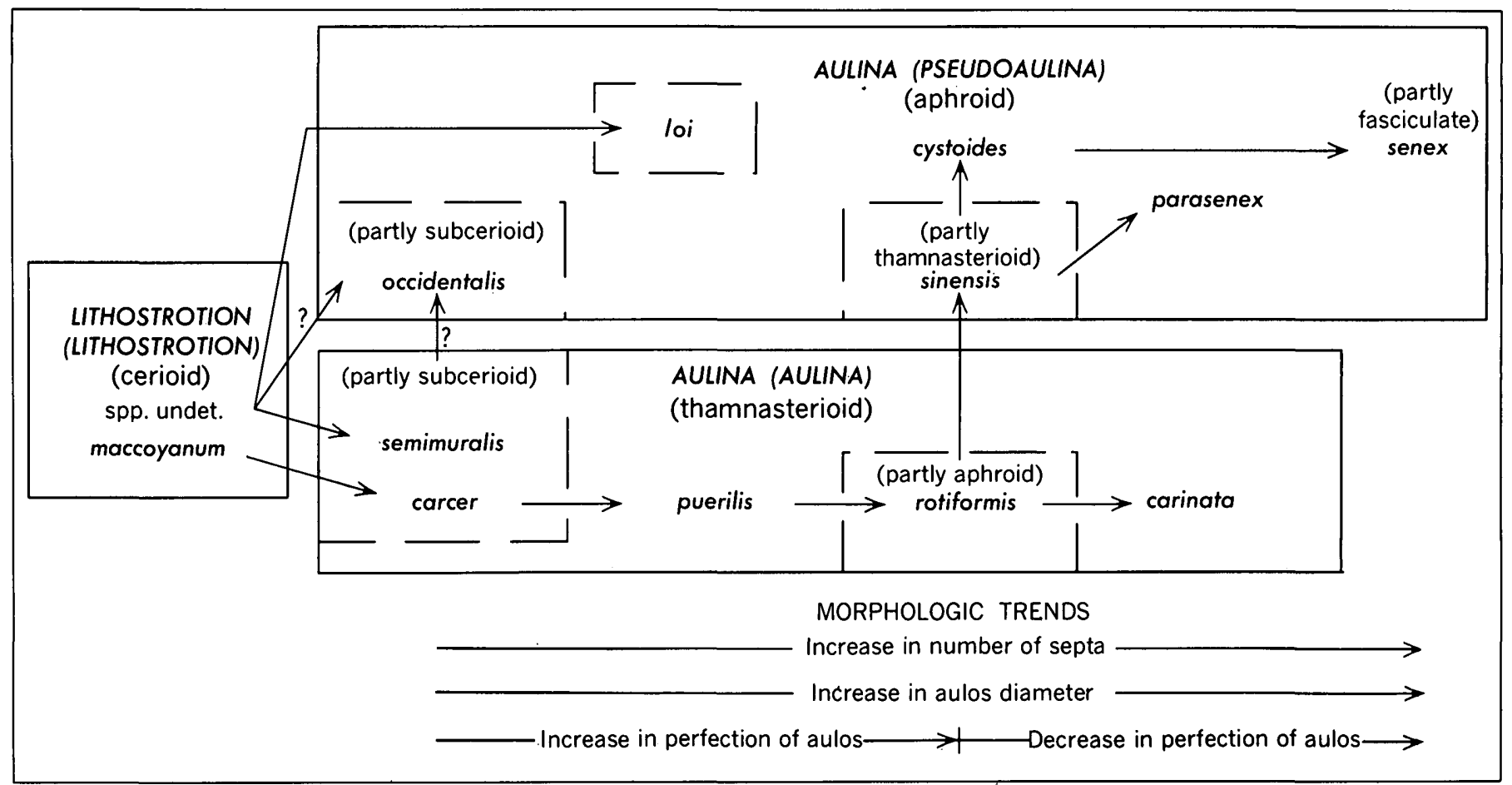

Froure 3.-Schematic phylogenetic relationships within the genus Aulina Smith. Dashed boxes denote "linking species."

All the species of Aulina, except $A$. (A.) semimuralis, $A$. (P.) occidentalis, and $A$. (P.) parasenex, occur in China, which seems to have been the source area from which the genus radiated to Japan, the U.S.S.R., and Britain. A. (A.) semimuralis and $A$. (P.) occidentalis seem to have been derived independently from the Lithostrotion (Lithostrotion) stock in North American. A. (P.) parasenex in the U.S.S.R. probably evolved by migration from the root stock in China.

Subgenus AULINA Smith, 1916, emend.

Type species.-Same as for genus Aulina.

Diagnosis.-Subcerioid to thamnasterioid Aulina.

Occurrence.-Represented by five species. Upper Viséan (England?, U.S.S.R., China, Japan); lower Namurian (England, Scotland, U.S.S.R.) ; upper Viséan or lower Namurian (U.S.A.).

\section{Aulina (Aulina) carcer Smith and Yü, 1943}

Aulina carcer Smith and Yü, 1943, p. 46, pl. 8, figs. 4-6; Wu, in $Y \ddot{u}$ and others, 1963, p. 72 , pl. 20 , fig. 4.

Aulina (Aulina) carcer Smith and Yü, Minato and Rowett, 1967, p. 386, 388.

Diagnosis.-Subcerioid to thamnasterioid Aulina with mature corallites whose centers are spaced 2-3 $\mathrm{mm}$ apart, 8-10 weakly carinate major septa and an equal number of minor septa. Aulos of small diameter present in only a few corallites, and a weak columella is formed in some corallites. Tabularium ordinarily about $1.5 \mathrm{~mm}$ in diameter, composed of tabulae that slope downward toward periphery of corallite.

Occurrence.-Upper Viséan (Yuanophyllum Zone) of China (Hunan).

Discussion.-This species links $A$. (A.) rotiformis with Lithostrotion (Lithostrotion) maccoyanum and could be placed in either of the two genera (Smith and Yii, 1943, p. 46).

\section{Aulina (Aulina) semimuralis Sando, 1963}

Aulina semimuralis Sando, 1963, p. 1077, pl. 146, flgs. 1-5. Aulina (Aulina) semimuralis Sando, Minato and Rowett, 1967, p. $386,388$.

Diagnosis.-Subcerioid to thamnasterioid Autina with mature corallites whose centers are spaced 7-9 $\mathrm{mm}$ apart, 14-18 strongly carinate major septa and an equal number of minor septa, a poorly formed aulos $0.5-1 \mathrm{~mm}$ in diameter, tabulae numbering $20-25$ in 5 $\mathrm{mm}$ in the aulos and about the same in the tabularium, and a tabularium about $0.5-1 \mathrm{~mm}$ wide.

Occurrence.-Upper Viséan or lower Namurian (Meramecian or Chesterian) of U.S.A. (Arizona).

Discussion.-The subcerioid corallites and poorly formed aulos of this poorly known species suggest close affinities to Lithostrotion (Lithostrotion).

Aulina (Aulina) puerilis Smith and Yü, 1943

Aulina puerilis Smith and Yü, 1943, p. 47, pl. 8, figs. 7,8 , pl. 9 , fig. $5 ; W u$, in $Y u ̈$ and others, 1963 , p. 72, pl. 20, figs. $3 \mathrm{a}, \mathbf{b}$.

Aulina (Aulina) puerilis Smith and Yu, Minato and Rowett, 1967, p. 386, 388. 
Diagnosis.-Thamnasterioid Aulina with mature corallites whose centers are spaced 4-6.5 mm apart, 1112 carinate major septa and an equal number of minor septa, an aulos $0.3-0.35 \mathrm{~mm}$ in diameter, tabulae numbering about 35 in $5 \mathrm{~mm}$ in the aulos and slightly less in the tabularium, and a tabularium about $0.6 \mathrm{~mm}$ wide.

Occurrence.--Upper Viséan (Yuanophyllum Zone) of China (Hunan).

Discussion.-This species differs from $A$. (A.) rotiformis in its smaller aulos diameter and greater number of tabulae. It is a logical intermediate between $A$. (A.) carcer and $A$. (A.) rotiformis.

Aulina (Aulina) rotiformis Smith, 1916

Phillipsastraea radiata (Martin), Smith, 1910, p. 629, 630; Garwood, 1912, p. 542, 543.

Aulina rotiformis Smith, 1916, p. 2, 3; Smith, 1917, p. 290, text figs. 3, 4 on p. 291, 292, pl. 22, figs. 6-11; Garwood and Goodyear, 1924, p. 252; Smith, 1925, p. 487, figs. 1a, b, 2a, b; Yü, 1933, p. 80 , pl. 13, figs. 1a-d; Hill, 1938, p. $13,25,31$; Hill, 1940, p. 191, pl. 11, figs. 6, 7 ; Smith and Y $\ddot{u}, 1943$ [part], p. 43, pl. 8, figs. 9-11, pl. 9, figs. 1-4; Dobrolyubova, 1958, p. 208, pl. 34, figs. 3a, b; Vasilyuk, 1960 , p. 98, pl. 23, figs. 1-1c; Yü, Lin, and Fan, 1962, p. 19, pl. 4, figs. 2a, b; Lo and Chao, 1962, p. 177, pl. 24, figs. 5a, b, 6, pl. 25, figs. $2 a, b ; W u$ in $Y \ddot{u}$ and others, 1963 , p. 71 , pl. 20 , figs. $2 a, b$; Vasilyuk, 1964, p. 92, pl. 7, figs. $8 \mathrm{a}, \mathrm{b}$; Lin, 1966, p. 189, pl. 3, figs. 1a, b.

Aulina (Aulina) rotiformis Smith, Minato and Rowett, 1967, p. 389 , pl. 47 , figs. $1-9$, pl. 48 , figs. $1,2$.

Aulina carinata var. chui $\mathrm{Y} \mathfrak{u}, 1933$, p. 82 , pl. 13 , figs. $2 \mathrm{a}, \mathrm{b}$; Vasilyuk, 1960, p. 98; Lo and Chao, 1962, p. 178; Wu in Yu and others, 1963, p. 71, pl. 20, figs. 6a, b.

Aulina (Aulina) carinata var. chui Yü, Minato and Rowett, 1967, p. 385, 388, 390.

Aulina rotiformis Smith var. irregularis $\mathrm{Lo}$, in Lo and Chao, 1962 , p. 178, pl. 24, figs. 4 a, b.

Aulina (Aulina) rotiformis var. irregularis Lo, Minato and Rowett, 1967, p. 386, 388.

Diagnosis.-Ordinarily thamnasterioid (parts of colony may be aphroid) Aulina with mature corallites whose centers are spaced 2-7 mm apart, 10-12 weakly carinate major septa and an equal number of minor septa, an aulos $0.5-1 \mathrm{~mm}$ in diameter, tabulae numbering about $20-25$ in $5 \mathrm{~mm}$ in the aulos and about the same in the tabularium, and a tabularium $0.4-0.5 \mathrm{~mm}$ wide.

Occurrence.-Upper Viséan (Yuanophyllum Zone) of China (Anhue, Hunan, Kansu, Sinkiang); upper Viséan $\left(\mathrm{D}_{2}-\mathrm{D}_{3}\right)$ of ?England (Yorkshire) and U.S.S.R. (Voronezh) ; upper Viséan of Japan (Hon$\mathrm{shu})$; lower Namurian $\left(\mathrm{E}_{2}\right)$ of England (Yorkshire, Northumberland) and Scotland (Ayrshire, Lanarkshire); upper Viséan and lower Namurian (Zones $\mathrm{C}_{1}{ }^{\mathrm{g}} \mathrm{g}-\mathrm{C}_{1}{ }^{\mathrm{n}} \mathrm{d}$ ) of U.S.S.R. (Donetz basin and Kirghizia).

Discussion.-This widespread species shows remarkably little variation in measurable morphologic char- acters. Vasilyuk's specimen from the Donetz basin of the U.S.S.R. and the specimen named Aulina carinata var. chui by Ÿ̈ (1933, p. 82) from China have slightly larger average aulos diameters than other specimens attributed to the species. The subspecies irregularis Lo (Lo and Chao, 1962, p. 178) was distinguished by the irregularity of its tabulae.

\section{Aulina (Aulina) carinata Yü, 1933}

Aulina carinata Yü, 1933, p. 81, pl. 14, flgs. 4a-c; Vasilyuk, 1960 , p. $98 ; \mathrm{Wu}$, in $Y \ddot{u}$ and others, 1963, p. 71 , pl. 20, figs. 1a, b; Lin, 1966, p. 190, pl. 3, flgs. $2 a$, b, pl. 4, figs. $4 a, b$.

Aulina rotiformis Smith, Smith and Yü, 1943, p. 43 [part].

Aulina (Aulina) carinata Yü, Minato and Rowett, 1967, p. $385,388$.

Diagnosis.-Thamnasterioid Aulina with mature corallites whose centers are spaced 3-8 mm apart, 13-16 strongly carinate major septa and an equal number of minor septa, an aulos 1-1.2 $\mathrm{mm}$ in diameter, tabulae numbering about $13-18$ in $5 \mathrm{~mm}$ in the aulos and about the same in the tabularium, and a tabularium about $0.6 \mathrm{~mm}$ wide.

Occurrence.-Upper Viséan (Yuanophyllum Zone) of China (Kansu).

Discussion.-This species differs from $A$. (A.) rotiformis in its larger number of septa, slightly larger aulos diameter, and fewer tabulae.

Subgenus PSEUDOAULINA Minato and Rowett, 1967

Type species.-Aulina senex Hill, 1940, p. 193, pl. 11, figs. $9,10$.

Diagnosis.-Predominantly aphroid Aulina.

Occurrence.-Represented by six species. Middle to upper Viséan (China); lower Namurian (England, Scotland, U.S.S.R.) ; upper Viséan or lower Namurian (U.S.A.).

Aulina (Pseudoaulina) occidentalis (Sando, 1963)

Aulina occidentalis Sando, 1963, p. 1078, pl. 146, figs. 6-10. Aulina (Pseudoaulina) occidentalis (Sando), Minato and Rowett, 1967, p. 386, 388.

Diagnosis.-Aphroid to subcerioid Pseudoaulina with mature corallites whose centers are spaced 7-12 $\mathrm{mm}$ apart, 23-28 weakly carinate major septa and an equal number of minor septa, an aulos $1.5-1.8 \mathrm{~mm}$ in diameter, tabulae numbering about $20-25$ in $5 \mathrm{~mm}$ in the aulos and about the same in the tabularium, and a tabularium $0.5-0.6 \mathrm{~mm}$ wide.

Occurrence.-Upper Viséan or lower Namurian (Meramecian or Chesterian) of U.S.A. (Arizona).

Discussion.-The species in distinguished from $A$. $(P$.) senex by its smaller, more perfectly formed aulos and larger number of septa and tabulae. Its weakly subcerioid corallites suggest derivation of the species 
from Aulina (Aulina) semimuralis or from an unknown Lithostrotion (Lithostrotion) progenitor.

Aulina (Pseudoaulina) loi n. sp.

Aulina cystoides var. a Lo, in Lo and Chao, 1962, p. 179, pl. 26, figs. 1a, b.

Aulina (Pseudoaulina) cystoides var. a (Lo), Minato and Rowett, 1967, p. 386, 388.

Holotype.-Academia Sinica Institute of Geology Fossil Catalog No. NZ 253-30 (General Catalog No. 01377).

Diagnosis.-Aphroid Pseudoaulina with mature corallites whose centers are spaced 3-7 mm apart, 13-15 carinate(?) major septa and an equal number of minor septa, a poorly formed aulos $0.5-0.9 \mathrm{~mm}$ in diameter, tabulae numbering about 13-23 in $5 \mathrm{~mm}$ in the aulos and about the same in the tabularium, and a tabularium about $0.5-0.7 \mathrm{~mm}$ wide.

Occurrence.-Middle Viséan (Thysanophyllum Zone) of China (Kansu).

Discussion.-This species is separated from Aulina (Pseudoaulina) cystoides (Lo) because of its larger number of septa, larger number of tabulae, and its imperfectly formed aulos penetrated by the axial ends of the major septa, which do not reach the axis of the corallite. The last feature links it closely to Lithostrotion (Lithostrotion). A. (P.) loi differs from $A$. (P.) senex by its smaller corallite spacing, fewer septa, smaller aulos diameter, and smaller tabularium width. It is the oldest known species of Aulina.

Aulina (Pseudoaulina) sinensis, n. sp.

Aulina sp. Lo and Chao, 1962, p. 180, pl. 25, flg. 1.

Holotype.-Academia Sinica Institute of Geology Fossil Catalog No. NZ 219-8 (General Catalog No. 01378).

Diagnosis.-Ordinarily aphroid Pseudoaulina (some corallites thamnasterioid) with mature corallites whose centers are spaced $2-3.5 \mathrm{~mm}$ apart, 9-10 carinate(?) major septa and an equal number of minor septa, an aulos $0.2-0.5 \mathrm{~mm}$ in diameter, and a tabularium about $0.5 \mathrm{~mm}$ wide. Number of tabulae unknown.

Occurrence.-Upper Viséan (Yuanophyllum Zone, $\mathrm{D}_{2}$ ) of China (Kansu).

Discussion.-This poorly known species is distinguished from $A$. $(P$.$) senex by its smaller corallite$ spacing, fewer septa, and smaller aulos diameter. Its partly thamnasterioid corallites and diminutive morphologic features suggest derivation from $A$. (A.) rotiformis.

Aulina (Pseudoaulina) cystoides (Lo, in Lo and Chao, 1962) Aulina cystoides Lo, in Lo and Chao, 1962, p. 178, pl. 25, figs. 3a, b, 4 ; Lin, 1966, p. 190, pl. 4, figs. 1a, b.
Aulina (Pseudoaulina) cystoides (Lo), Minato and Rowett, 1967, p. 386, 388.

Diagnosis.-Aphroid Pseudoaulina with mature corallites whose centers are spaced 3-5 mm apart, 10-12 carinate (?) major septa and an equal number of minor septa, an aulos $0.5-0.9 \mathrm{~mm}$ in diameter, tabulae numbering about $10-15$ in $5 \mathrm{~mm}$ in the aulos and about the same in the tabularium, and a tabularium about 0.5-0.9 $\mathrm{mm}$ wide.

Occurrence.-Upper Viséan (Yuanophyllum Zone) of China (Kansu).

Discussion.-This species differs from $A$. (P.) senex by its smaller corallite spacing, fewer septa, smaller aulos diameter, and smaller tabularium width. It compares favorably with $A$. (A.) rotiformis in most morphologic details but differs by having aphroid rather than thamnasterioid corallites. This similarity, together with the presence of some aphroid corallites in some specimens of $A$. (A.) rotiformis, suggests derivation of $A$. (P.) cystoides from $A$. (A.) rotiformis through $A$. $(P$.$) sinensis.$

Aulina (Pseudoaulina) parasenex (Vasilyuk, 1960)

Aulina parasenex Vasilyuk, 1960, p. 99, pl. 24, figs. 2, $2 a$.

Aulina (Pseudoaulina) parasenex (Vasilyuk), Minato and Rowett, 1967, p. 386, 388.

Diagnosis.-Aphroid Pseudoaulina with mature corallites whose centers are spaced 8-12 mm apart, 13-15 strongly carinate major septa and an equal number of minor septa, an aulos 1.25-1.5 mm in diameter, tabulae numbering about 18-21 in the aulos and about the same in the tabularium, and a tabularium about $1 \mathrm{~mm}$ wide.

Occurrence.-Lower Namurian (Zone $\mathrm{C}_{1}{ }^{\mathrm{n}} \mathrm{b}$ ) of U.S.S.R. (Donetz basin).

Discussion.-This species differs from $A$. (P.) senex in its fewer septa, smaller aulos diameter, and larger number of tabulae.

\section{Aulina (Pseudoaulina) senex (Hill, 1938)}

Aulina sp. Yü, 1937, p. 54, 55.

Autina senex Hill, 1938, p. 13, 24, 31; Hill, 1940, p. 193, pl. 11, figs. 9, 10; Smith and Yu, 1943, p. 47, pl. 9, flgs. 6-10; Wu, 1964, p. 32, pl. 3, flgs. $1,2$.

Aulina (Pseudoaulina) senex (Hill), Minato and Rowett, 1967, p. $386,388$.

Aulina manchuriensis Yabe and Minato, 1944, p. 148, pl. 14, figs. $1-5$, pl. 15, figs. $1-3$, text flgs. $1-10 ; W u$ in $Y \mathfrak{u}$ and others, 1963, p. 72 , pl. 20 , flg. 5 .

Aulina (Pseudoaulina) manchuriensis (Yabe and Minato), Minato and Rowett, 1967 , p. $386,388$.

Diagnosis.-Aphroid to subfasciculate Pseudoaulina with mature corallites whose centers are spaced 9-20 $\mathrm{mm}$ apart, 16-23 weakly carinate major septa and an equal number of minor septa, a poorly formed aulos 1.5-3 in diameter, tabulae numbering about 7-14 in 5 
$\mathrm{mm}$ in aulos and about the same in the tabularium, and a tabularium 1-4 mm wide.

Occurrence.-Upper Viséan (Yuanophyllum Zone) of China (Kwangsi, Hunan, Kirin) and Lower Namurian $\left(\mathrm{E}_{2}\right)$ of England (Northumberland) and Scotland (Ayrshire).

Discussion.-Present definition of this widely recognized species includes considerable variation in important morphologic characters. The fasciculate tendency noted in an English specimen (Smith and Yü, 1943, p. 48, pl. 9, fig. 7) seems to be a secondary feature of the corallum. The species seems to represent a phylogerontic stage of the Aulina lineage (Smith and Yü, 1943, p. 47).

\section{Genus SOLENODENDRON n. gen.}

Type species.-Aulina horsfieldi Smith and $\mathrm{Yü}$, 1943 , p. 49 , pl. 10, figs. 3-6.

Diagnosis.-Fasciculate aulate corals in which the aulos is formed by union of deflected axial ends of major septa. Major and minor septa carinate, carinae of zigzag type. Dissepimentarium regular. Tabulae in aulos ordinarily flat, horizontal; tabulae in tabularium slope downward toward periphery of corallite. Increase lateral in some species, axial (parricidal) in others. Microstructure unknown.

Occurrence.-Represented by five species (one questionably referred to the genus). Upper Tournaisian (England) ; lower Viséan (England, Wales, France?) ; middle Viséan (Wales, Ireland?) ; upper Viséan (England, Scotland, Ireland, U.S.S.R., China?, Laos, France).

Discussion.-The relatively well known stratigraphic ranges of the British species S. horsfieldi, S. hibernicum, and $S$. furcatum (Clarke, 1966) permit placing these species in a phylogenetic series in which $S$. horsfieldi is derived from an unknown species of Lithostrotion (Siphonodendron) in the late Tournaisian, $S$. hibernicum is derived from $S$. horsfieldi in the middle Viséan, and S. furactum is derived from S. hibernicum in the late Viséan (fig. 2). This postulated series is characterized by the following morphologic trends: Decrease in corallite diameter, decrease in aulos diameter, decrease in septal number, and increase in complexity of budding. When this reasoning is used, the morphology of the Russian species S. kosvensis suggests derivation from $S$. horsfieldi in the late Viséan. The Asian S.? yohi does not fit very well in this scheme but is provisionally placed as an offshoot of $S$. horsfieldi in the late Viséan.

Contrary to the proposed phylogenesis is the occurrence of ancestral lithostrotionid characters in some corallites of S. furcatum and S. kosvensis, which suggests that these species may be more closely related to the Lithostrotion (Siphonodendron) rootstock. In fact, Clarke (1966, p. 226) suggested that each of the three British species was derived from a different species of Lithostrotion. More information is needed on the geographic and stratigraphic distribution of the species in question to determine which of the alternatives is correct.

Species showing some similarities to Solenodendron are Aulina novella Kachanov (in Spasskiy and Kachanov, 1971, p. 51, pl. 1, figs. 3a-d) and Diphyphyllum? vesicotabulatum Yü $(1933$, p. 87, pl. 14, figs. 5a-d, pl. 15, figs. 5a, b; see also Smith and Yü, 1943, p. 54). I do not consider either of these species to have a true aulos such as is found in Solenodendron. Moreover, neither species has carinate septa. A. novella is further distinguished from the species of Solenodendron by having a much larger ratio of the tabulate axial zone to the corallite diameter. I refer $A$. novella to Diphyphyllum. D.? vesicotabulatum has a morphology transitional between Lithostrotion (Siphonodendron) and Diphyphyllum. Pending further information on $D . ?$ vesicotabulatum, I conclude that this species should remain questionably in Diphyphyllum.

\section{Solenodendron horsfieldi (Smith and Yï, 1943)}

Diphyphyllum concinnum Lonsdale, Delépine, 1930, p. 35, pl. 3, figs. 11a-c.

Aulina horsfieldi Smith and Yü, 1943, p. 49, pl. 10, figs. 3-6; Clarke, 1966, p. 222, 225, fig. 1 ; Minato and Rowett, 1967, p. $385,387$.

Diagnosis.-Subphaceloid Solenodendron with mature corallites $8-14 \mathrm{~mm}$ in diameter, 30-32 weakly to strongly carinate major septa and an equal number of minor septa, an aulos about half the width of the tabularium $(1.5-3 \mathrm{~mm})$, tabulae numbering about 15 in $5 \mathrm{~mm}$ in the aulos and about 20 in $5 \mathrm{~mm}$ in the tabularium, and a dissepimentarium $1.5-2.5 \mathrm{~mm}$ wide composed of three or more rows of regular dissepiments. Increase is lateral, nonparricidal.

Occurrence.-Upper Tournaisian to lower Viséan $\left(C_{1}\right)$ of England (Yorkshire, Somerset) ; lower to middle Viséan $\left(\mathrm{C}_{2}\right.$ and $\left.\mathrm{S}_{1}\right)$ of South Wales; and lower(?) to upper Viséan $\left(\mathrm{C}_{2}\right.$ ? $\left.-\mathrm{D}_{1}\right)$ of France (Normandy).

Discussion.-S. horsfieldi is the oldest known species of Solenodendron and has the longest stratigraphic range of any of the species. Clark $(1966$, p. 226) suggested that the species was derived from an early form of Lithostrotion (Siphonodendron) martini (MilneEdwards and Haime), although I have not seen any record of $L$. (S.) martini below the Viséan in Britain. However, species of Lithostrotion (Siphonodendron) are known from the middle and upper Tournaisian of North America. 


\section{Solenodendron hibernicum (Clarke, 1966)}

Aulina hibernica Clarke, 966, p. 222, pl. 20, figs. 1a, b, 2a, b.

Diagnosis.-Dendroid to subphaceloid Solenodendron with mature corallites ordinarily $5.5-7 \mathrm{~mm}$ in diameter, 22-25 carinate major septa and an equal number of minor septa, an aulos about half the width of the tabularium $(2-3 \mathrm{~mm})$, tabulae numbering about 15 in $5 \mathrm{~mm}$ in the aulos and about 10 in $5 \mathrm{~mm}$ in the tabularium, and a dissepimentarium $0.5-1 \mathrm{~mm}$ wide composed of one to three rows of regular dissepiments. Increase is parricidal, ordinarily bipartite.

Occurrence.-Middle (?) to upper Viséan $\left(\mathrm{S}_{2}\right.$ ? $\left.-\mathrm{D}_{1}\right)$ of Ireland (Clare, Kerry, Meath).

Discussion.-This species is distinguished from $S$. horsfieldi by its smaller corallites, fewer septa, fewer dissepiments, and parricidal increase. It was probably derived from $S$. horsfieldi.

Solenodendron furcatum (Smith, 1925)

Aulina furcata Smith, 1925, p. 490, pl. 24, figs. 3-7, text figs. A-C on p. 491 ; Hill, 1938 , p. 13, 24, 29; Hill, 1940, p. 192, pl. 11, fig. 8 ; Smith and Yü, 1943, p. 48, pl. 10, figs. 1, 2 ; Fontaine, 1961, p. 120, pl. 10, flg. 10, pl. 14, fig. 2, pl. 18, fig. 1, pl. 19, fig. 6; Clarke, 1966, p. 222, 225, fig. 1; Minato and Rowett, 1967, p. 385, 387.

Diagnosis.-Subphaceloid Solenodendron with mature corallites $3-6 \mathrm{~mm}$ in diameter, 18-22 weakly to strongly carinate major septa and an equal number of minor septa, an aulos about half the width of the tabularium (1-2 mm), tabulae numbering about 10-12 in $5 \mathrm{~mm}$ in the aulos and about $12-15$ in the tabularium, and a dissepimentarium $0.5-1 \mathrm{~mm}$ wide composed of one or two rows of regular dissepiments. Increase is parricidal, typically quadripartite.

Occurrence.-Upper Viséan $\left(\mathrm{D}_{1}-\mathrm{D}_{2}\right)$ of England (Derbyshire), Scotland (Dumfriesshire), Ireland (Clare, Westmeath, Meath, Dublin), and Laos.

Discussion.-S. furcatum is distinguished from $S$. horsfieldi by its smaller corallites, fewer septa, fewer dissepiments, more perfectly formed aulos, and parricidal increase. Smith and Yü (1943, p. 49) noted that one abortive corallite in a paratype of the species has a columella and major septa that meet at the axis (figured by Smith, 1925, pl, fig. 7), which betrays the lithostrotionid ancestry of the species. Although Clarke $(1966$, p. 226$)$ suggested that the species was derived from Lithostrotion junceum, it seems more logical to regard it as the culmination of the $S$. horsfieldi-S. hibernicum lineage.

Solenodendron kosvensis (Rakshin, 1965)

Aulina kosvensis Rakshin, 1965, p. 54, pl. 4, figs. 1a, b.

Diagnosis.-Subphaceloid Solenodendron with mature corallites $6-8 \mathrm{~mm}$ in diameter, $20-23$ sinuous to carinate major septa and an equal number of minor septa, an aulos (imperfectly formed in some corallites) about $1 \mathrm{~mm}$ in diameter, tabulae numbering about eight or nine in $5 \mathrm{~mm}$ in aulos and about seven or eight in $5 \mathrm{~mm}$ in tabularium, and a dissepimentarium about $1 \mathrm{~mm}$ wide composed of two or three rows of regular dissepiments. Increase lateral(?).

Occurrence.-Upper Viséan (Ladeininskii horizon) of U.S.S.R. (central Ural Mountains).

Discussion.-S. kosvensis is distinguished from $S$. horsfieldi by its smaller corallites, fewer major septa, fewer dissepiments, and smaller aulos diameter. Rakshin $(1965$, p. 55) noted that the aulos is open, that one or two septa extend into it, and that in one corallite the aulos is not formed at all and nearly all major septa extend to the axis. These features are indicative of lithostrotionid ancestry. The general morphology of this species suggests that it was derived from $S$. horsfieldi.

Solenodendron? yohi, (Yü, 1933)

Lithostrotion martini Yoh, 1929, p. 72.

Crepidophyllum? yohi Yü, 1933, p. 88, pl. 19, flgs. 1a-c; Smith and $\mathrm{Ytu}, 1943, \mathrm{p} .54$.

Aulina yohi (Yu), Hill, 1940, p. 193.

[?] "Aulina" cf. yohi Yu, Fontaine, 1861, p. 122, pl. 20, figs. $11,12$.

Aulina? yohi ( $\mathrm{Yu}$ ), Minato and Rowett, 1967, p. 385, 387.

Diagnosis.-Fasciculate, subcerioid, or subthamnasterioid Solenodendron with mature corallites as much as $16 \mathrm{~mm}$ in diameter, as many as $24-26$ strongly carinate major septa and an equal number of minor septa, an aulos $2-3 \mathrm{~mm}$ in diameter, tabulae numbering about 10 in $5 \mathrm{~mm}$ in both aulos and tabularium, and a dissepimentarium about $5 \mathrm{~mm}$ wide composed of two or three rows of regular dissepiments. Mode of increase unknown.

Occurrence.-Upper Viséan (Yuanophyllum Zone?) of China (Kwangsi) ; upper Viséan of Laos(?).

Discussion.-The growth form of this poorly known species is in doubt. Yii's (1933) description of the type material suggests a fasciculate to subcerioid or subthamnasterioid corallum. Hill (1940) regarded the species as plocoid, and Smith and Yü (1943) described it as subplocoid. Minato and Rowett (1967) included the species questionably in their fasciculate group. Fontaine (1961) compared specimens of a solitary or fasciculate coral with this species. If further study should prove that the species is not fasciculate, it probably should be removed from Solenodendron.

$S . ?$ yohi is distinguished from $S$. horsfieldi by its larger corallites, fewer septa, and fewer dissepiments.

Genus AULOSTYLUS n. gen.

Type species. - Lithostrotionella tubifera Hayasaka, 1936, p. 69, pl. 16, figs. 1a, b, 2. 
Diagnosis.-Cerioid aulate corals in which the aulos is formed by union of deflected axial ends of major septa. Columella ordinarily present, a vertically discontinuous axial plate formed by prolongation of one or two major septa. Major and minor septa noncarinate or weakly carinate (zigzag type). Tabulae in aulos ordinarily horizontal, flat, commonly turned up at intersection with columella; tabulae in tabularium ordinarily concave upward, horizontal to slightly inclined toward periphery of corallite. Dissepimentarium lonsdaleoid. Wall structure obscure, seemingly fibro-. normal, with median dark line. Septal structure obscure, seemingly amorphous, with traces of median dark lines in some septa at peripheral ends.

Occurrence.-Represented by three species (one questionably referred). Middle Tournaisian (U.S.A. and Canada); (?) upper Viséan (China).

Discussion.-The general morphology of this genus, particularly its lonsdaleoid dissepimentarium, cerioid form, and columella, suggests that it was derived from Lithostrotionella. The ancestral species was probably L. microstylum (White) or one of the similar forms that are common in the middle and upper Tournaisian of North America. In some corallites, particularly younger ones in a corallum, the aulos wall is imperfect, and many major septa reach the columella; this is also indicative of derivation from Lithostrotionella. Possible occurrence in the upper Viséan of China is anomalous and needs to be checked by more complete description of the material.

\section{Aulostylus tubiferus (Hayasaka, 1936) emend. Figures 4 and 5}

Lithostrotionella tubifera Hayasaka, 1936, p. 69, pl. 16, figs. 1a, b, 2; Smith and Yü, 1943, p. 42; Sando, 1963, p. 1076. Auline tubifera (Hayasaka), Hill, 1940, p. 190; Bamber, 1961, p. 161 , pl. 12 , figs. $3 a-d$.
Diagnosis.-Aulostylus with mean major septal number 14-16, mean large corallite diameter $6-8 \mathrm{~mm}$, mean aulos diameter $1-1.5 \mathrm{~mm}$, mean tabularium width $0.8-1$ $\mathrm{mm}$, and mean dissepimentarium width 1-2 mm. Tabulae number $6-16$ in $5 \mathrm{~mm}$ in aulos and about the same in tabularium. Aulos ordinarily well formed but imperfect in some corallites. Columella present in most corallites. Dissepimentarium lonsdaleoid, consists of a single row of dissepiments of variable size and shape. Corallum hemispherical to tabular. Increase peripheral.

Occurrence.-Upper middle to lower upper Tournaisian (Mamet Zones 7-8) of U.S.A. (Montana) and Canada (British Columbia).

Discussion.-Specimens referred to this species show little variation in most measurable characters (table 1). However, two coralla that deviate from the others in having an imperfect aulos are recognized as a separate subspecies.

\section{Aulostylus tubiferus tubiferus (Hayasaka, 1936) \\ Figures $4 a-g$}

Lithostrotionella.tubifera Hayasaka, 1936 [part], p. 69, pl. 16, figs. 1a, b [not 2].

Material and occurrence.-Holotype, USNM 120247. USGS loc. 5894-PC: float probably from Woodhurst Member of Lodgepole Limestone (upper middle to lower upper Tournaisian, Zone $\mathrm{C}_{1}$ of Sando and others, 1969), crest of ridge east of Old Baldy at altitude about $9,000 \mathrm{ft}(2,743 \mathrm{~m})$, probably in sec. 26 or $27, \mathrm{~T} .7 \mathrm{~S}$., R. 3 W., Varney quadrangle, Madison County, Mont., U.S.A. (see Hadley, 1969, for geologic map); collected by R. W. Richards.

Hypotypes, GSC 42558 and GSC 42559. GSC loc. C-7379, float from $200-500 \mathrm{ft}(60-150 \mathrm{~m})$ above base of Rundle Group (lower upper Tournaisian, Mamet Zone 8), East Sukunka River section, lat $55^{\circ} 1.5^{\prime}$. N., long

TABLE 1.-Measurements of coralla of Aulostylus $n$. gen.

[All internal measurements made on 20 largest corallites in one transverse thin section made from each corallum except for counts of tabulae, which were made on two or three corrallites in longitudinal thin section. Mean dissepimentarium width $=\frac{a-(b+2 c)}{2}$, where $a$ is mean maximum large corallite diameter; $b$, mean aulos diameter; and $c$, mean tabularium width. Frequency of columella is number of corallites showing columellar traces in transverse thin section divided by 20 (number of corallites measured)]

\begin{tabular}{|c|c|c|c|c|c|c|c|c|c|c|c|c|c|c|c|}
\hline \multirow[b]{2}{*}{ Taxon and specimen No. } & \multicolumn{3}{|c|}{ Corallum } & \multicolumn{2}{|c|}{$\begin{array}{l}\text { Number of } \\
\text { major septa }\end{array}$} & \multicolumn{2}{|c|}{$\begin{array}{c}\text { Maximum large } \\
\text { corallite } \\
\text { diameter } \\
(\mathrm{mm}) \\
\end{array}$} & \multicolumn{2}{|c|}{$\begin{array}{c}\text { Aulos } \\
\text { diameter } \\
(\mathrm{mm})\end{array}$} & \multicolumn{2}{|c|}{$\begin{array}{c}\text { Tabularium } \\
\text { width } \\
(\mathrm{mm})\end{array}$} & \multirow{2}{*}{$\begin{array}{c}\text { Mean } \\
\text { dissep- } \\
\text { - iment- } \\
\text { arium } \\
\text { width } \\
(\mathrm{mm})\end{array}$} & \multicolumn{2}{|c|}{$\begin{array}{l}\text { Number of } \\
\text { tabulae in } \\
5 \mathrm{~mm}\end{array}$} & \multirow{2}{*}{$\begin{array}{c}\text { Fre- } \\
\text { quency } \\
\text { of } \\
\text { colu- } \\
\text { mella }\end{array}$} \\
\hline & $\begin{array}{l}\text { Growth } \\
\text { form }\end{array}$ & $\begin{array}{c}\text { Height } \\
(\mathrm{cm})\end{array}$ & $\begin{array}{l}\text { mum } \\
\text { diam- } \\
\text { eter } \\
\text { (cm) }\end{array}$ & Range & Mean & Range & Mean & Range & Mean & Range & Mean & & Aulos & $\begin{array}{l}\text { Tabu. } \\
\text { larium }\end{array}$ & \\
\hline \multirow{3}{*}{ 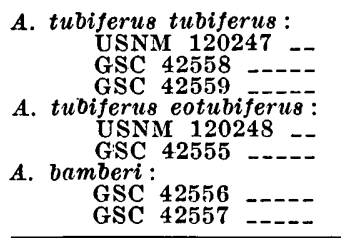 } & $\begin{array}{l}\text { Hemispherical -- } \\
\text { Unknown }\end{array}$ & $\begin{array}{r}8+ \\
10+ \\
9+\end{array}$ & $\begin{array}{l}14 \\
10+ \\
9+\end{array}$ & $\begin{array}{l}14-17 \\
14-18\end{array}$ & $\begin{array}{l}15.5 \\
15.8\end{array}$ & $\begin{array}{l}6.5-9.0 \\
6.0-8.0 \\
5.5-8.0\end{array}$ & $\begin{array}{ll}7.8 & 1 \\
6.7 \\
6.5 & 1\end{array}$ & $\begin{array}{l}1.0-1.8 \\
1.0-1.2\end{array}$ & $\begin{array}{l}1.4 \\
1.1\end{array}$ & $\begin{array}{r}0.8-1.0 \\
.6-1.0^{?}\end{array}$ & $\begin{array}{r}0.97 \\
? \\
.77\end{array}$ & $\begin{array}{l}2.2 \\
1.9\end{array}$ & $\begin{array}{c}6-9 \\
9-11 \\
12-16\end{array}$ & $\begin{array}{r}6-8 \\
\text { ca. } 11 \\
\text { ca. } 9\end{array}$ & $\begin{array}{r}0.75 \\
? \\
.90\end{array}$ \\
\hline & $\begin{array}{l}\text { Tabular } \\
\text { Unknown }\end{array}$ & $\begin{array}{l}5 \\
?\end{array}$ & $17+$ & $\begin{array}{l}12-16 \\
14-18\end{array}$ & $\begin{array}{l}14.2 \\
15.3\end{array}$ & $\begin{array}{l}5.0-7.5 \\
5.0-7.0\end{array}$ & $\begin{array}{l}6.0 \\
6.0\end{array}$ & $\begin{array}{r}.8-1.2 \\
1.0-1.5\end{array}$ & $\begin{array}{l}1.0 \\
1.4\end{array}$ & $\begin{array}{l}.7-1.0 \\
.8-1.2\end{array}$ & $\begin{array}{r}.81 \\
1.02\end{array}$ & $\begin{array}{l}1.7 \\
1.3\end{array}$ & $\begin{array}{r}9-16 \\
\text { ca. } 10\end{array}$ & $\begin{array}{r}11-14 \\
9-10\end{array}$ & $\begin{array}{l}.85 \\
.80\end{array}$ \\
\hline & $\begin{array}{l}\text { Hemispherical _- } \\
\text { Tabular? }\end{array}$ & $\begin{array}{l}10 \\
10+\end{array}$ & $\begin{array}{l}20 \\
15+\end{array}$ & $\begin{array}{l}15-19 \\
14-16\end{array}$ & $\begin{array}{l}16.7 \\
14.8\end{array}$ & $\begin{array}{l}5.5-8.5 \\
5.0-7.5\end{array}$ & $\begin{array}{ll}7.2 & 1 \\
6.5 & 1\end{array}$ & $\begin{array}{l}1.5-2.2 \\
1.2-2.0\end{array}$ & $\begin{array}{l}1.8 \\
1.6\end{array}$ & $\begin{array}{l}.5-1.0 \\
.5-1.0\end{array}$ & .74 & $\begin{array}{l}2.0 \\
1.7\end{array}$ & $\begin{array}{r}10-11 \\
\text { ca. } 9\end{array}$ & $\begin{array}{ll}\text { ca. } 9 & 0 \\
\text { ca. } 9 & 0\end{array}$ & $\begin{array}{r}-0.30 \\
-.10\end{array}$ \\
\hline
\end{tabular}



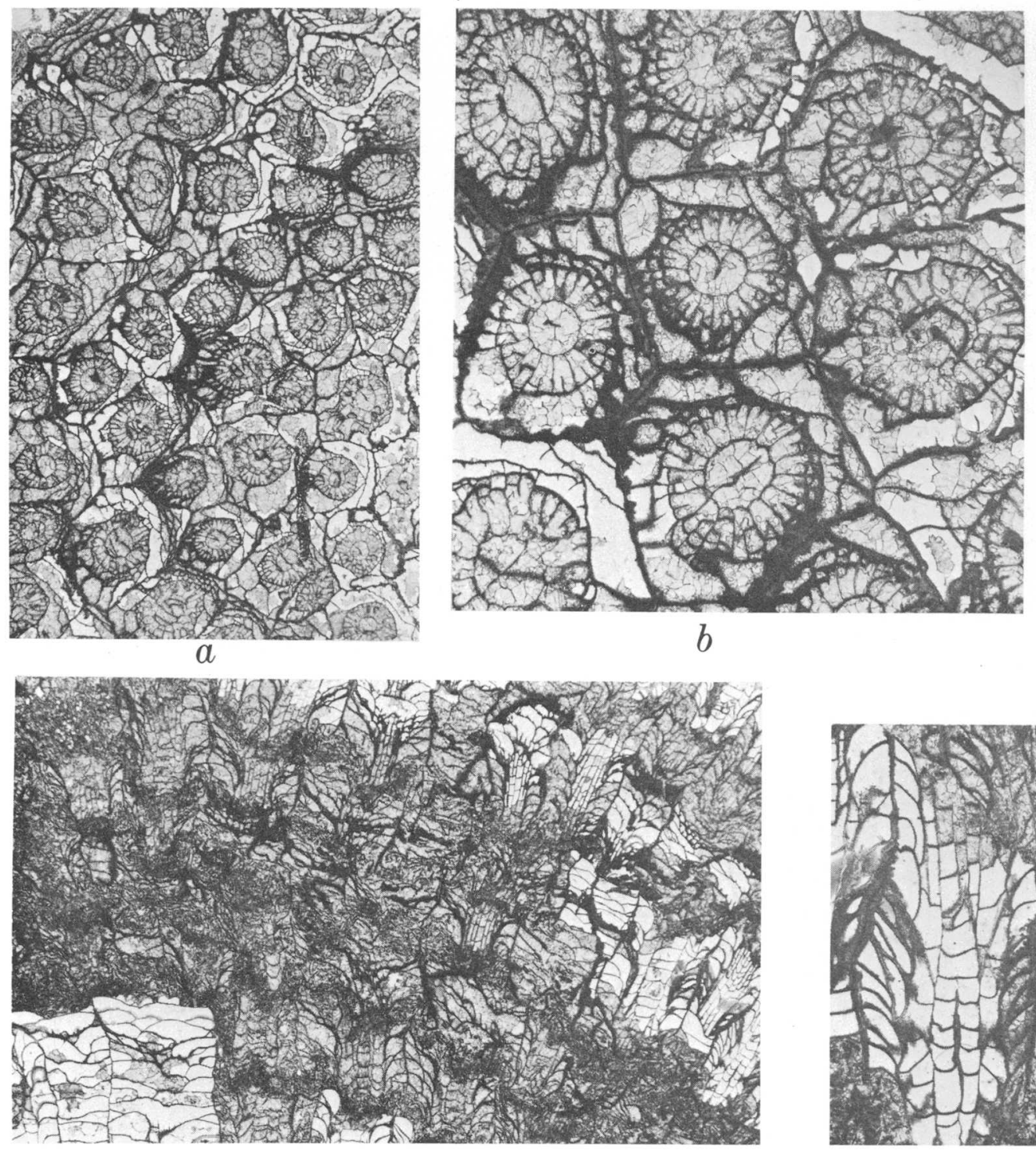

$c$

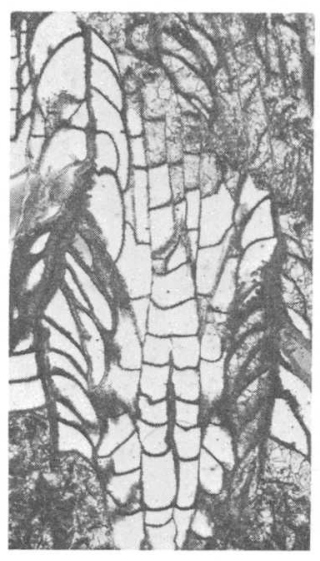

$f$

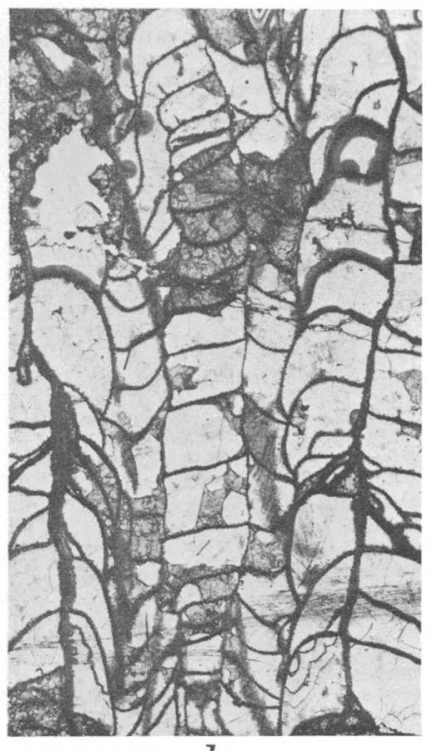

$d$
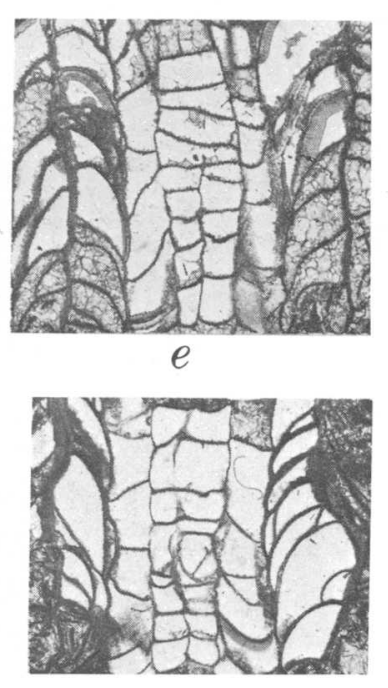

$g$

FIgURe 4.-Aulostylus tubiferus tubiferus (Hayasaka), Holotype, USNM 120247a, b. Thin sections are as follows: $a$, Transverse, $\times 2 . \quad b$, Transverse, $\times 6 . \quad c$, Longitudinal, $\times 2 . \quad d-g$, Longitudinal, $\times 6$.

$121^{\circ} 38^{\prime}$ W., northeastern British Columbia, Canada; collected by E. W. Bamber.

Diagnosis.-Aulostylus tubiferus with mean major septal number 15.5-15.8, mean large corallite diameter 6.5-7.8, mean aulos diameter 1.1-1.4 mm, mean tabularium width $0.77-0.97$, and mean dissepimentarium width $1.9-2.2 \mathrm{~mm}$. Tabulae number $6-16$ in $5 \mathrm{~mm}$ in aulos and $6-11$ in $5 \mathrm{~mm}$ in tabularium. Aulos well formed, rarely penetrated by more than two major septa. Columella present in most corallites (frequency $0.75-0.91)$.

Description of holotype.-Corallum hemispherical, about $14 \mathrm{~cm}$ in maximum diameter and more than $8 \mathrm{~cm}$ high. Increase peripheral; offsets arise in the dissepimentarium.

Measurements of important morphological characters are given in table 1 .

Corallite walls straight to beaded or denticulate, 0.1$0.8 \mathrm{~mm}$ thick, microstructure seemingly fibronormal, with median dark line. Aulos wall well defined, formed by deflected axial ends of major septa. Major septa straight to zigzag, thinning toward axial end, 0.03-0.2 $\mathrm{mm}$ thick, mostly confined to tabularium but commonly extending into disseptimentarium as crests on upper surfaces of dissepiments. Minor septa ordinarily onethird to one-half length of major septa, confined to 
tabularium except for a few extensions as crests on dissepiments. Septal microstructure obscure, seemingly amorphous, with traces of median dark line in peripheral ends of some septa. Carinae absent or poorly developed, zigzag type. Columella formed by prolongation of one axially swollen major septum into aulos, vertically discontinuous. Rarely one or two other major septa may extend to columella. In rare corallites, columella may be free of septal attachment. Dissepiments globose to flattened, variable in size, inclined toward corallite axis, forming a single row. Tabulae in aulos ordinarily horizontal, flat, commonly turned up at intersection with columella. Tabulae in tabularium horizontal or slightly inclined toward periphery of corallite, ordinarily concave upward, not continuous with tabulae in aulos.

Discussion.-The Canadian specimens deviate slightly from the holotype in their smaller corallites, smaller aulos, narrower tabularium, narrower dissepimentarium, and more abundant tabulae. GSC 42558 is too poorly preserved for measurement of most features.

\section{Aulostylus tubiferus eotubiferus n. subsp.}

Figures $5 a-e$

Lithostrotionella tubifera Hayasaka, 1936 [part], p. 69, pl. 16, fig. 2.

Aulina tubifera (Hayasaka), Bamber, 1961, p. 161, pl. 12, figs. $3 a-d, 4 a-g$.

Material and occurrence.-Holotype, USNM 120248. USGS loc. 3290-PC: Woodhurst Member of Lodgepole
Limestone (upper middle to lower upper Tournaisian, Zone $\mathrm{C}_{1}$ of Sando and others, 1969 ; Mamet Zones 7-8), near Lime Spur, probably in sec. $17,18,19$, or 20 , T. 1 N., R. 2 W., Jefferson Island quadrangle, Jefferson or Madison County, Mont., U.S.A. (see Chelini, 1965, fig. 5, for geologic map); collected by D. C. Bard.

Paratype, GSC 42555. GSC loc. C-37921: Lower part of Rundle Group, Burnt River section, lat $55^{\circ} 12^{\prime}$ N., long $122^{\circ} 2.5^{\prime}$ W., northeastern British Columbia, Canada; collected by E. W. Bamber.

Diagnosis.-Aulostylus tubiferus with mean major septal number 14.2-15.3, mean large corallite diameter $6.0 \mathrm{~mm}$, mean aulos diameter $1.0-1.4 \mathrm{~mm}$, mean tabularium width $0.8-1.0 \mathrm{~mm}$, and mean dissepimentarium width $1.3-1.7 \mathrm{~mm}$. Tabulae number $9-16$ in $5 \mathrm{~mm}$ in aulos and about 9-11 in $5 \mathrm{~mm}$ in tabularium. Aulos ordinarily well formed but imperfect in about 25 percent of corallites, where as many as all major septa reach columella. Columella present in most corallites (frequency $0.80-0.85$ ).

Description of holotype.-Corallum tabular, about $5 \mathrm{~cm}$ high and more than $17 \mathrm{~cm}$ in maximum diameter. Increase is peripheral; offsets arise in the dissepimentarium.

Measurements of important morphological characters are given in table 1.

Corallite walls straight to beaded or denticulate, 0.1$0.5 \mathrm{~mm}$ thick, microstructure seemingly fibronormal,
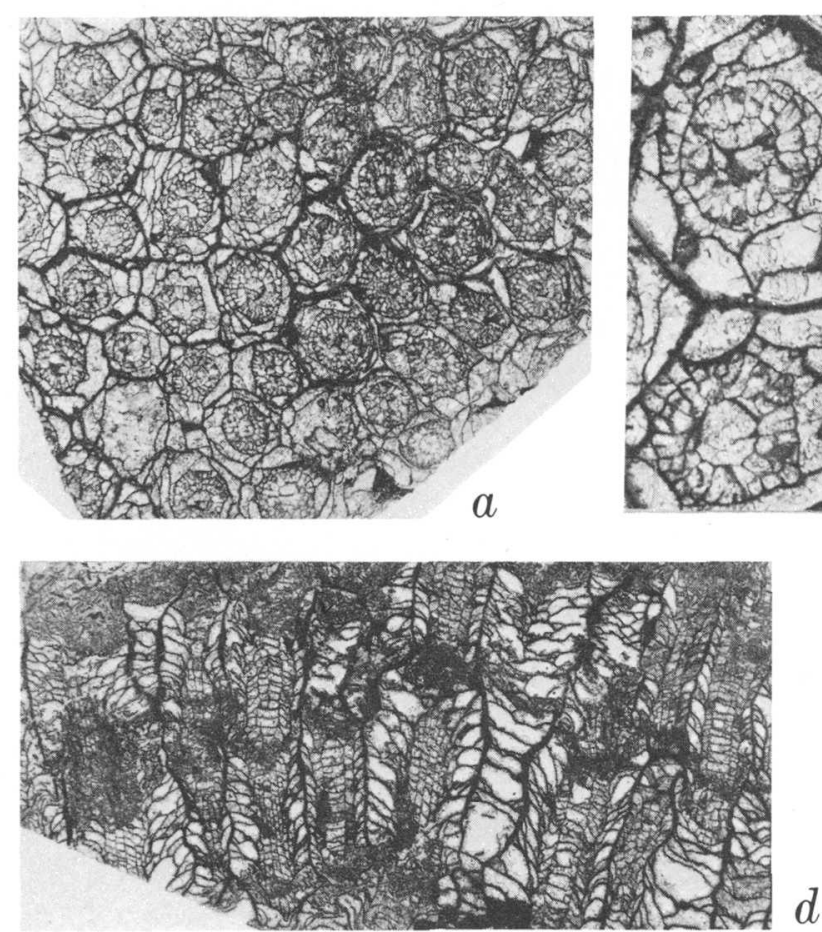

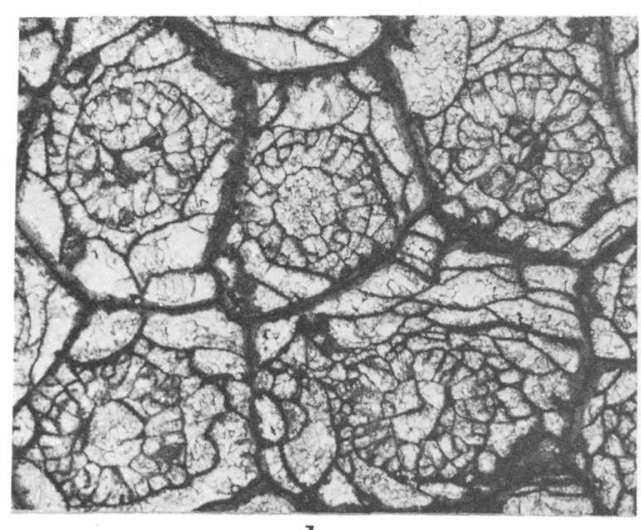

$b$
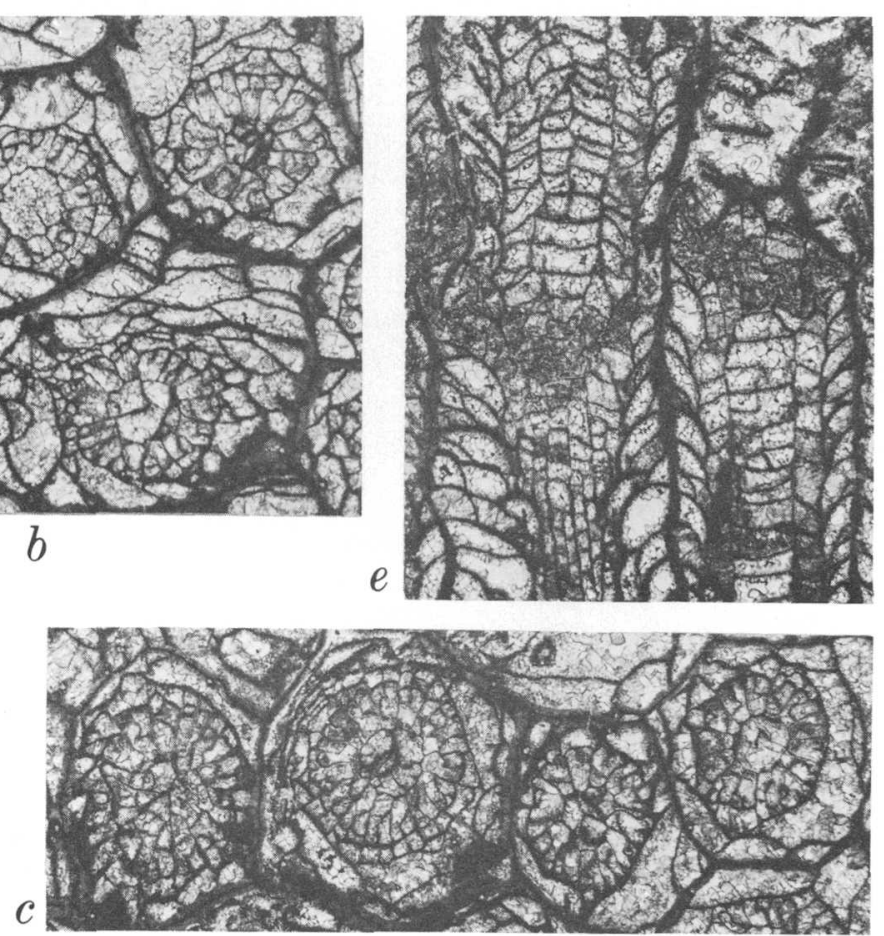

Figure 5.-A Alostylus tubiferus eotubiferus n. subsp. Holotype, USNM 120248d, e. Thin sections are as follows: a. Transverse, $\times 2 . \quad b-c$. Transverse, $\times 6 . d$. Longitudinal, $\times 2$. $\quad e$. Longitudinal, $\times 6$. 
with median dark line. Aulos wall formed by deflected axial ends of major septa, poorly defined in about 25 percent of corallites. Major septa straight to zigzag, thinning toward axial ends, $0.03-0.1 \mathrm{~mm}$ thick, some extending into dissepimentarium as crests on upper surfaces of dissepiments. Minor septa ordinarily onethird to one-half length of major septa, confined to tabularium except for a few extensions into dissepimentarium as crests on dissepiments. Septal microstructure obscure, seemingly amorphous, with traces of median dark lines in some septa at peripheral ends. Columella formed by prolongation of one axially swollen major septum or two opposing major septa into aulos, vertically discontinuous, rarely free of septal attachment. In about 25 percent of the corallites, as many as all major septa may join columella; this phenomenon is most common in younger corallites. Dissepiments globose to flattened, variable in size, forming a single row, inclined toward axis of corallite. Tabulae in aulos ordinarily horizontal, flat, turned up at intersection with columella. Tabulae in tabularium horizontal or slightly inclined toward periphery of corallites, ordinarily concave upward, not continuous with tabulae in aulos.

Discussion.-This subspecies differs from $A$. tubiferus tubiferus by having a significant proportion of its corallites characterized by an imperfect aulos in which the major septa reach the columella, a feature that is particularly common in younger corallites. The presence of these corallites suggest that this subspecies is more closely related to the ancestral Lithostrotionella species from which Aulostylus was derived than $A$. tubiferus tubiferus.

The Canadian paratype deviates slightly from the holotype in its larger septal number, larger aulos, wider tabularium, narrower dissepimentarium, and fewer tabulae.

\section{Aulostylus bamberi n. sp.}

Figures $\mathbf{6} a-d$

Material and occurrence.-Holotype, GSC 42556, and paratype, GSC 42557. GSC loc. C-4603: Lower part of Rundle Group (lower upper Tournaisian, Mamet Zone 8 ?), within about $150 \mathrm{ft}(46 \mathrm{~m})$ of base), North Burnt River section, lat $55^{\circ} 14.5^{\prime} \mathrm{N}$., long $122^{\circ} 5^{\prime} \mathrm{W}$., northeastern British Columbia, Canada; collected by E. W. Bamber.

Diagnosis.-Aulostylus with mean major septal number 14.8-16.7, mean large corallite diameter $6.5-7.2 \mathrm{~mm}$, mean aulos diameter $1.6-1.8 \mathrm{~mm}$, mean tabularium width $0.73-0.74 \mathrm{~mm}$, and mean dissepimentarium width $1.7-2.0 \mathrm{~mm}$. Tabulae number $9-11$ in $5 \mathrm{~mm}$ in aulos and about nine in $5 \mathrm{~mm}$ in tabularium. Aulos well formed.
Columella absent or very rare. Corallum hemispherical to tabular(?). Increase peripheral.

Description of holotype.-Corallum hemispherical, $10 \mathrm{~cm}$ high by $20 \mathrm{~cm}$ in maximum diameter. Increase is peripheral; offsets arose in the dissepimentarium.

Measurements of important morphological characters are given in table 1.

Corallite walls straight to beaded, as much as $0.3 \mathrm{~mm}$ thick, microstructure seemingly fibronormal, with median dark line. Aulos wall well defined, formed by deflected axial ends of major septa. Major septa straight to sinuous, about 0.03-0.1 mm thick, confined to tabularium except for rare extensions into dissepimentarium as crests on upper surfaces of dissepiments. Minor septa ordinarily one-third to one-half length of major septa, confined to tabularium. Septal microstructure obscure. Carinae absent or rare. Columella absent or very rare. Dissepiments globose to flattened, variable in size, inclined toward corallite axis, forming a single row. Tabulae in aulos horizontal, flat. Tabulae in tabularium horizontal or slightly inclined toward periphery of corallites, ordinarily concave upward, not continuous with tabulae in aulos.

Discussion.-This species is distinguished from Aulostylus tubiferus by having a more perfectly formed aulos and in the absence or extreme rarity of a columella. Transverse sections of most corallites are clearly without a columella, but a few show obscure traces that may represent a columella. No evidence of a columella was seen in longitudinal section. These features suggest that $A$. bamberi represents the culmination in aulos development in the Aulostylus lineage. The species is also distinguished from $A$. tubiferus by having a much smaller ratio of tabularium width to aulos width.

The paratype deviates slightly from the holotype in having fewer major septa, smaller corallites, a smaller aulos, and a narrower dissepimentarium.

Aulostylus? sp.

Lithostrotionella sp. A Lo and Chao, 1962, p. 184, pl. 19, flg. 1. Occurrence.-Upper Viséan (Yuanophyllum Zone) of China (Kansu).

Discussion.-Available information on this species consists of a brief description and a poorly illustrated transverse thin section, which does not provide an adequate basis for certain placement in Aulostylus. The occurrence is much higher than other known species of Aulostylus.

Genus VESICULOTUBUS n. gen.

Type species.-Aulina vesiculata Dobrolyubova, in Dobrolyubova and Kabakovich, 1966, p. 163, pl. 33, figs. 1a-c. 

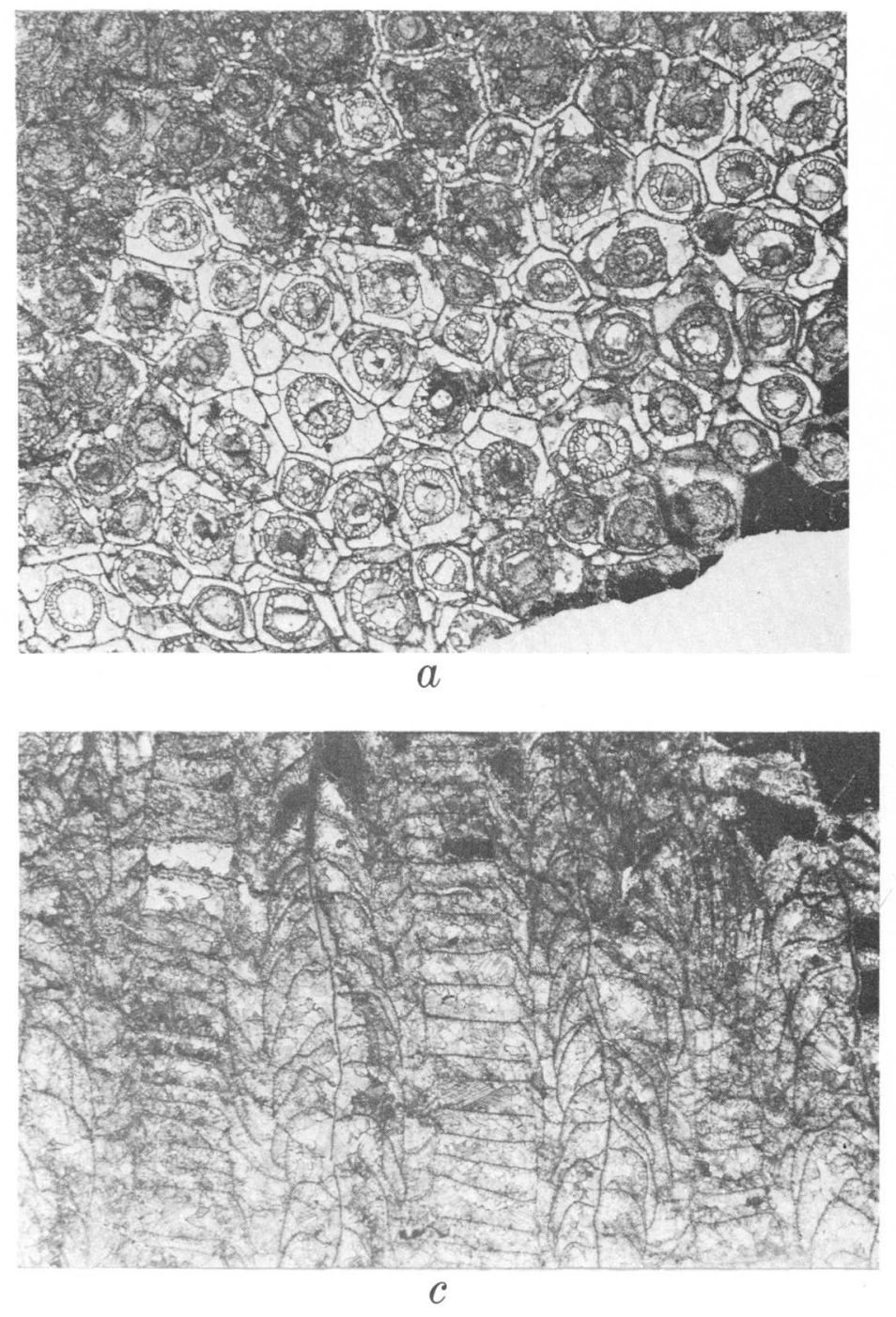
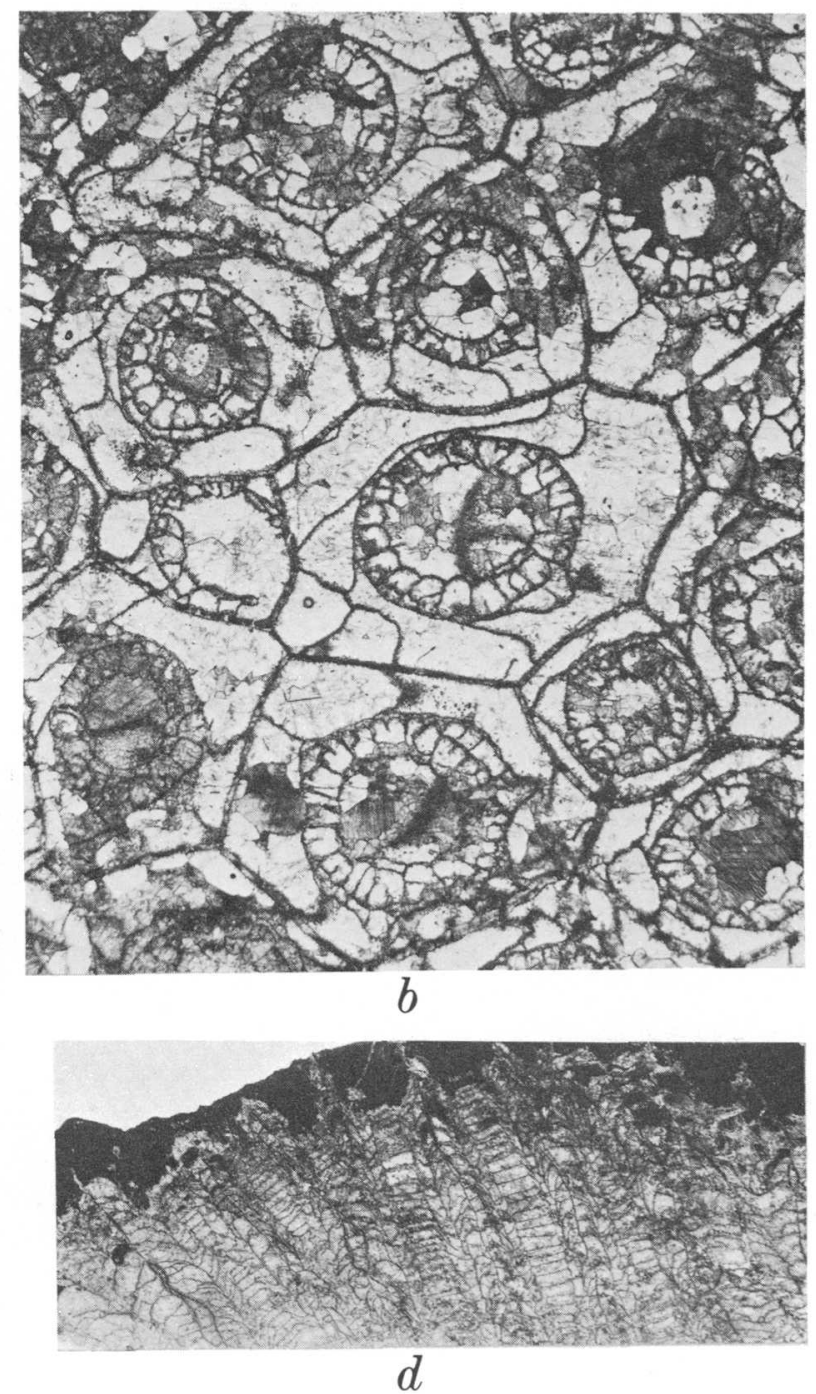

Figure 6.-Aulostylus bamberi n. sp. Holotype, GSC 42556a, b. Thin sections are as follows: $a$. Transverse, $\times 2$. $b$. Transverse, $\times 6$. c. Longitudinal, $\times 6$. $\quad d$. Longitudinal, $\times 2$.

Diagnosis.-Fasciculate aulate corals. Major and minor septa noncarinate or weakly carinate (zigzag type?). Dissepimentarium lonsdaleoid. Tabulae in aulos flat, horizontal; tabulae in tabularium complete to incomplete, flat, concave, or convex upward and ordinarily sloping downward toward periphery of corallite. Increase lateral. Microstructure unknown.

Occurrence.-Represented only by the type species, which is known only from the upper Tournaisian of the U.S.S.R. (Kuznetsk basin).

Discussion.-Derivation of this poorly known genus is obscure. The most similar corals at the same or lower stratigraphic levels in the U.S.S.R. are early species of Lithostrotionella, which have a lonsdaleoid dissepimentarium but have a cerioid rather than fasciculate growth form. The most similar fasciculate species is
Solenodendron horsfieldi, which seems to have been derived from Lithostrotion (Siphonodendron) in the late Tournaisian and is unknown in the U.S.S.R. Available evidence favors tentative derivation of Vesiculotubus as a fasciculate aulate offshoot of Lithostrotionella.

Family AULOPHYLLIDAE Dybowski, 1873 Genus AULOKONINCKOPHYLLUM n. gen.

Type species.-Campophyllum carinatum Carruthers, 1909, p. 150, pl. 1, figs. 3-6.

Diagnosis.-Solitary or pseudofasciculate aulate corals in which aulos is poorly defined and formed mainly by union of deflected axial ends of major septa and partly by tabulae. Major septa long, carinate; carinae of zigzag type. Cardinal fossula ordinarily present. Dissepimentarium regular. Tabulae in aulos ordi- 
narily flat, horizontal; tabulae in tabularium complete or incomplete, sloping downward toward periphery of corallite. Increase seemingly lateral or peripheral. Septal microstructure trabecular.

Occurrence.-Represented by three species (one questionably referred to the genus). Upper Viséan (England?, Algeria, U.S.S.R., Laos, Australia?) ; lower Namurian (Algeria, U.S.S.R.).

Discussion.-The solitary or pseudofasciculate growth form of this genus distinguishes it from other aulate Carboniferous corals.

Derivation from Koninckophyllum Thomson and Nicholson (anticipated by Smith and Yü, 1943, p. 53, and Fontaine, 1961, p. 120) is suggested by the form of the corallum, long major and minor septa, broad dissepimentarium, and cardinal fossula of most of the species of Aulokoninckophyllum and the occurrence of carinae in some associated species of Koninckophyllum (Smith and Yü, 1943, p. 53; Semenoff-Tian-Chansky, 1974, p. 107-135). Aulokoninckophyllum? simplex (Hill), presently regarded as a primitive member of the genus, may actually belong in a separate genus.

\section{Aulokoninckophyllum? simplex (Hill, 1934)}

Aulina simplex Hill, 1934 , p. 93 , pl. 11, figs. 12-29, text flg. 4; Smith and Yiu, 1943, p. 52, pl. 9, figs. 11-15; Vasilyuk, 1960 , p. 97 ; Fontaine, 1961 , p. 120 ; Minato and Rowett, 1967, p. 384 ; Jull, 1969, p. 131.

Amplexocarinia simplex (Hill), Smith, 1955, p. 87.

Diagnosis.-Solitary (cylindrical) Aulokoninckophylluam with corallum as much as $8 \mathrm{~mm}$ in diameter, about 20 noncarinate major septa and an equal number of short minor septa, a poorly formed aulos $2-4 \mathrm{~mm}$ in diameter, tabulae numbering about seven or eight in 5 $\mathrm{mm}$ in both aulos and tabularium, and a narrow impersistent dissepimentarium composed of a single row of dissepiments. Microstructure unknown.

Occurrence.-Upper Viséan of Australia (Queensland).

Discussion.-Placement of this species in Autina Smith as a probable ancestral member of that genus by Hill (1934, p. 92) was challenged by Smith and Yü (1943, p. 52), who suggested that $A$. simplex was probably a caninoid that followed the aulate trend and that it represents a new genus. Smith (1955, p. 87) later referred the species to Amplexocarinia Soshkina, and Minato and Rowett (1967, p. 387) also suggested this assignment as a possibility, but Jull (1969, p. 131) pointed out that the species differed from other known representatives of Amplexocarinia by having minor septa and dissepiments. Moreover, in Amplexocarinia, the aulos is formed by the tabulae rather than by deflected axial ends of the major septa as in $A$. simplex.
A. simplex is distinguished from the colonial aulate corals of the Carboniferous by its solitary growth form and the lack of carinae. No morphologic evidence has been found to link it with these colonial forms. It could not be the ancestor of fasciculate forms because it occurs later than the earliest known fasciculate species (fig. 1). Available evidence favors placement as a primitive member of the solitary forms referred to Aulokoninckophyllum, which are regarded as aulate derivatives of Koninckophyllum. Placement in Aulokoninckophyllum is tentative because of the lack of carinae, the lack of a cardinal fossula, and the general morphologic simplicity of this species.

\section{Aulokoninckophyllum carinatum (Carruthers, 1909)}

Campophyllum carinatum Carruthers, 1909, p. 150, pl. 1, figs. 3-6; Gorskiy, 1938, p. 8; Smith and Yiu, 1943, p. 52.

Aulina carinata (Carruthers), Hill, 1938, p. 13; Hill, 1940, p. 190 ; Vasilyuk, 1960, p. 100, pl. 24, figs. 1-1c; Fontaine, 1961 , p. 121 , pl. 20 , figs. 5, 6; Vasilyuk, 1964, p. 92, pl. 7, fig. 9; Minato and Rowett, 1967, p. 385, 387; SemenoffTian-Chansky, 1974 , p. 50 , text figs. 16-18, pl. 3, flgs. 1-8, pl. 4, figs. 1-6.

Diagnosis.-Solitary (conical to cylindrical) or pseudofasciculate Aulokoninckophyllum with mature corallites $10-28 \mathrm{~mm}$ in diameter, 24-54 ordinarily strongly carinate major septa and an equal number of long minor septa (one-half to two-thirds length of major septa), a poorly formed aulos 3-5 $\mathrm{mm}$ in diameter, tabulae numbering about $6-16$ in $5 \mathrm{~mm}$ in the aulos and about $7-10$ in $5 \mathrm{~mm}$ in the tabularium, and a dissepimentarium 2-10 mm wide composed of 4-16 rows of regular dissepiments. Cardinal fossula weakly to strongly developed. Increase seemingly lateral or peripheral. Septal microstructure trabecular.

Occurrence.-Upper Viséan of U.S.S.R. (Novaya Zemlya), Laos, and (?)England (Yorkshire, $\mathrm{D}_{2}$ ) ; upper Viséan to lower Namurian of Algeria and U.S.S.R. (Donetz basin, Zones $\mathrm{C}_{1}{ }^{\mathrm{v}} \mathrm{g}-\mathrm{C}_{1}{ }^{\mathrm{n}} \mathrm{d}$ ).

Discussion.-Much doubt has been expressed about the growth form of this species. The type specimens were described as cylindrical solitary forms by Carruthers $(1909$, p. 150), but Smith and Yü $(1943$, p. 53) pointed out that they might represent a fasciculate coral in which the corallites were disaggregated, and Semenoff-Tian-Chansky (1974, p. 53) suggested that the types may be from small colonies. Cylindrical and conical fragments attributed to the species by Vasilyuk $(1960$, p. 100) were described as solitary coralla. Fontaine (1961, p. 121-122) was uncertain about the growth form of the cylindrical fragments he referred to the species. Minato and Rowett $(1967$, p. 385) regarded the species as fasciculate. A plausible solution to the growth-form problem is offered by the Algerian 
specimens described by Semenoff-Tian-Chansky (1974, p. 50-54, pls. 3, 4), who found that although most of his specimens were simple conical forms, one showed a branching corallum produced by budding. This evidence suggests that the corallum of this species, though basically solitary, may produce small, pseudofasciculate growth forms.

Specimens attributed to the species show considerable variation in measurable morphologic characters, suggesting that there may be more than one species represented.

Similarity to Koninckophyllum is particularly noteworthy in the Algerian specimens.

Aulokoninckophyllum amarensis (Semenoff-Tian-Chansky, 1974) Aulina amarensis (Semenoff-Tian-Chansky, 1974, p. 54, pl. 12, figs. $1-4$.

Aulina sp. Semenoff-Tian-Chansky, 1974, p. 55, pl. 27, figs. $5,6$.

Diagnosis.-Solitary (conical) Aulokoninckophyllum with corallum $24 \mathrm{~mm}$ in maximum diameter, as many as 51 weakly carinate major septa and an equal number of minor septa, a poorly formed aulos as much as $4.8 \mathrm{~mm}$ in diameter, tabulae numbering about four in $5 \mathrm{~mm}$ in the aulos and about six in $5 \mathrm{~mm}$ in the tabularium, and a narrow dissepimentarium composed of one or two rows of dissepiments. Cardinal fossula well developed.

Occurrence.-Upper Viséan of Algeria.

Discussion.-This species is distinguished from $A$. carinatum mainly by its narrower dissepimentarium, weaker carinae, and fewer tabulae.

\section{REFERENCES CITED}

Bamber, E. W., 1961, Mississippian corals from northeastern British Columbia, Canada: Princeton, N.J., Princeton Univ., Ph.D. thesis, 199 p., 14 pls., 1 text fig.

Carruthers, R. G., 1909, Notes on the Carboniferous corals collected in Nowaja Semlja by Dr. W. S. Bruce, in Lee, G. W., A Carboniferous fauna from Nowaja Semlja, collected by W. S. Bruce: Royal Soc. Edinburgh Trans., v. 47 , pt. 1, p. 148-156, pl. 1.

Chelini, J. M., 1965, Limestone, dolomite, and travertine in Montana : Montana Bur. Mines and Geology Bull. 44, 53 p., 15 figs.

Clarke, M. J., 1966, A new species of fasciculate Aulina from Ireland: Royal Dublin Soc. Sci. Proc., ser. A, v. 2, no. 14, p. 221-227, pl. 20, 1 text fig.

Delépine, G., 1930, Contribution à l'etude de la faune du calcaire de Sable-Les polypiers: Soc. Linnéene Normandie Mém. 2, Sec. Géol., new ser., v. 1, fasc. 1, p. 25-40, pl. 3.

Dobrolyubova, T. A., 1958, Nizhnekamennougol'nye kolonial'nye chetyrekhluchevye korally Russkoi platformy [Lower Carboniferous colonial tetracorals from the Russian platform] : Akad. Nauk SSSR, Paleont. Inst. Trudy, v. 70, 216 p. 38 pls. [in Russian].
Dobrolyubova, T. A., and Kabakovich, N. V., 1966, Chetyrekhluchevye korally Nizhnego Karbona Kuznetskoy kotloviny [Tetracorals from the Lower Carboniferous of the Kuznetsk basin], in Dobrolyubova, T. A., Kabakovich, N. V., and Sayutina, T. A., Korally Nizhnego Karbona Kuznetskoy kotloviny [Corals from the Lower Carboniferous of the Kuznetsk basin], Akad. Nauk SSSR, Paleont. Inst. Trudy, v. 111, p. 5-198, pls. 1-36, text figs. 1-16 [in Russian].

Dybowski, W. N., 1873, Monographie der Zoantharia sclerodermata rugosa aus der Silurformation Estlands, Nord-Livlands, und der Insel Gotland * **: Archiv Naturkunde, Liv.-, Ehst-, Kurlands, ser. 1, v. 5, p. 257-414, pls. 1, 2.

Fontaine, Henri, 1961, Les madréporaires paleozoïques du Viêt-Nam, du Laos, et du Cambodge: Archives Géol. ViêtNam, no. 5, 276, p., 35 pls.

Garwood, E. J., 1912, The Lower Carboniferous succession in the North-West of England: Geol. Soc. London Quart. Jour., v. 68 , p. 449-582, pls. 44-56.

Garwood, E. J., and Goodyear, E., 1924, The Lower Carboniferous succession in the Settle District and along the line of the Craven faults: Geol. Soc. London Quart. Jour., v. 80 , p. 184-271, pls. $10-21$.

Gorskiy, I. I., 1938, Kammenougol'nye korally Novoi Zemli [Carboniferous corals from Novaya Zemlya], in Nalivkin, D V., ed., Paleontologiya Sovetskoy Arktiki [Paleontology of the Soviet Arctic]: Vses. Arkticheskii Inst. Trudy, v. 93, pt. 2, 221 p., 16 pls., 82 text flgs. [in Russian, with English summary].

Hadley, J. B., 1969, Geologic map of the Varney quadrangle, Madison County, Montana: U.S. Geol. Survey Geol. Quad. Map GQ-814.

Hayasaka, Ichirô, 1936, On some North American species of Lithostrotionella: Taihoku Imperial Univ., Fac. Sci. and Agriculture Mem., v. 13, no. 5, Geol. no. 12, p. 47-73, 8 pls.

Hill, Dorothy, 1934, The Lower Carboniferous corals of Australia: Royal Soc. Queensland Proc., v. 45, no. 12, p. 63115 , pls. $7-11,6$ text figs.

1938, A monograph on the Carboniferous rugose corals of Scotland, pt. 1: Palaeontographical Soc., London, p. 1-78, pls. $1,2$.

1940, A monograph on the Carboniferous rugose corals of Scotland, pt. 3: Palaeontographical Soc., London, p. 115-204, pls. 6-11.

- 1956, Rugosa, in Moore, R. C., ed., Treatise on invertebrate paleontology, pt. F, Coelenterata: New York and Lawrence, Kans., Geol. Soc. America and Univ. Kansas Press, p. 233-324.

Jull, R. K., 1969, The Lower Carboniferous corals of eastern Australia-A review, in Campbell, K. S. W., ed., Stratigraphy and Palaeontology-Essays in honour of Dorothy Hill: Canberra, Australia Natl. Univ. Press, p. 120-139, pls. 9, 10, text figs. 23-27.

Kato, Makoto, 1963, Fine skeletal structures in Rugosa: Hokkaido Univ. Fac. Sci. Jour., ser. 4, v. 11, no. 4, p. 571-630, 3 pls., 19 text figs.

Lin, I. D., 1966, [Tetracorals from the Lower Carboniferous of Tsin-tai (Kansu Province) and Tsschun-wei (Ninsya autonomous region) ]: Acta Paleontologica Sinica, v. 14, no. 2, p. 185-197, pls. 1-4 [in Chinese, with Russian summary].

Lo, C. T., and Chao, C. M., 1962, [Lower Carboniferous tetracorals of the Chilien-shan (Tsinghai) district], in [Geology of Chilien-shan Mountains], v. 4, no. 3: Peking, Science Press, p. 111-199, pls. 1-30, [in Chinese]. 
Minato, Masao, and Rowett, C. L., 1967, Discovery of the genus Aulina Smith in the Carboniferous of Japan: Hokkaido Univ. Fac. Sci. Jour., ser. 4, v. 13, no. 4, p. 383393, 1 text fig., pls. $47,48$.

Orbigny, A. d', 1851, Cours élémentaire de paléontologie et de géologie stratigraphiques, pt. 3, Éléments zoologiques: Paris, V. Masson, t. 2, fasc. 1, 258 p.

Rakshin, P. P., 1965, Novye Vizeyskie rugozy s zapadnogo sklona Urala [New Visean rugose corals from west slopes of Urals] : Paleont. Zhur., 1965, no. 1, p. 54-59, pl. 4 [translated into English in Internat. Geology Rev., 1965, v. 7 , no. 12, p. $2115-2120,1$ pl.].

Sando, W. J., 1963, New species of colonial rugose corals from the Mississippian of northern Arizona: Jour. Paleontology, v. 37, no. 5, p. 1074-1079, 1 fig., pls. 145, 146.

Sando, W. J., Mamet, B. L., and Dutro, J. T., Jr., 1969, Carboniferous megafaunal and microfaunal zonation in the northern Cordillera of the United States: U.S. Geol. Survey Prof. Paper 613-E, 29 p., 7 text figs.

Semenoff-Tian-Chansky, P., 1974, Recherches sur les Tétracoralliaires $d u$ Carbonifère du Sahara occidental: [France], Centre Natl. Recherche Sci. ser. geol., no. 21, 316 p., 76 pls., 100 text-figs.

Smith, Stanley, 1910, The faunal succession of the Upper Bernician: Natl. History Soc. Northumberland, Durham, and Newcastle-upon-Tyne Trans., new ser. v. 3, p. 591645, pls. 16-18.

1916, Aulina rotiformis, gen. et sp. nov., Phillipsastraea hennahi (Lonsdale), and the genus Orionastraea: Geol. Soc. London Abs. Proc. 1916-17, p. 2-4.

1917, Aulina rotiformis, gen. et sp. nov., Phillipsastraea hennahi (Lonsdale), and Orionastraea, gen. nov.: Geol. Soc. London Quart. Jour., v. 72, p. 280-307.

- 1925, The genus Aulina: Annals and Mag. Nat. History, ser. 9, v. 16, p. 485-496, pl. 24.

1955, Amplexocarinia cravenensis sp. nov.: A Lower Carboniferous coral from the Clitheroe district, Lancashire: Great Britain Geol. Survey Bull. 7, p. 85-88, pl. 12.

Smith, Stanley, and Yü, C. C., 1943, A revision of the coral genus Aulina Smith and descriptions of new species from Britain and China: Geol. Soc. London Quart. Jour., no. $393-394$, v. 99 , pt. $1-2$, p. 37-61.
Spasskiy, N. Ya., and Kachanov. E. I., 1971, Novye primitivnye rannekamennougol'nye korally Altaya i Urala [New primitive corals found in the Lower Carboniferous of Altai and the Urals]: Leningrad, Gorniy Inst. Zapiski, v. 59, no. 2, p. 48-64, 5 pls. [in Russian].

Vasilyuk, N. P., 1960, Nizhnekammenougl'nye korally Donetskogo basseina [Lower Carboniferous corals of the Donetz basin ] : Akad. Nauk Ukrainskoi SSR, Inst. Geol. Nauk, Trudy, Ser. Stratig. Paleont., vyp. 13, 179 p., 42 pls. [in Russian].

1964. Korally zon $\mathrm{C}_{1}{ }^{\nabla} \mathrm{g}-\mathrm{C}_{1}{ }^{\mathrm{n}} \mathrm{a}$ Dontskogo basseina [Corals of zones $\mathrm{C}_{1}{ }^{\mathrm{v}} \mathrm{g}-\mathrm{C}_{1}{ }^{\mathrm{n}} \mathrm{a}$ of the Donetz basin], in Aizenverg, D. E., ed., Materialui $\mathrm{k}$ fayune verkhnego paleozoya Donbassa 2 [Materials for the upper Paleozoic fauna of the Donetz basin]: Akad. Nauk Ukrainskoi SSR, Inst. Geol. Nauk Trudy, Ser. Stratig. Paleont., vyp. 48, p. 60103. pls. 1-8 [in Ukrainian].

Wu, W. S., 1964, [Lower Carboniferous corals in central Hunan]: Acad. Sinica, Inst. Geol. and Paleont. Mem. 3, p. 1-100, pls. 1-16 [in Chinese, with English summary].

Yabe, Hisakatsu, and Minato, Masao, 1944, Eine Aulina-Art aus der Mandschurei: Japanese Jour. Geology Geography, v. 19 , nos. $1-4$, p. $147-150$, pls. $14,15.1$ text-fig.

Yoh, S. S., 1929, Geology and mineral resources of northern Kwangsi: Kwangtung and Kwangsi Geol. Survey Ann. Rept. v. 2, pt. 2, p. 59-101.

Yü, C. C., 1933 [1934] Lower Carboniferous corals of China : Palaeontologia Sinica, ser. B, v. 13, fasc. 3, 211 p., 24 pls.

1937, The Fengninian (lower Carboniferous) corals of South China: Natl. Research Inst. Geol. (Acad. Sinica) Mem. 16, 111 p., 12 pls.

Yui, C. C., Lin, I. D., and Fan, Y. N., 1962, [The rugose corals of the Permo-Carboniferous periods in Sinkiang and Chinghai (Tsinghai) provinces]: [Changchun Geol. Acad., 10th Ann. Sci. Paper], p. 13-35, pls. 1-4 [in Chinese].

Yii. C. M., Wu. W. S.. Chao, C. M., and Chang, C. C., 1963, [Fossil corals of China]: Peking, 390 p., 98 pls., [in Chinese]. 


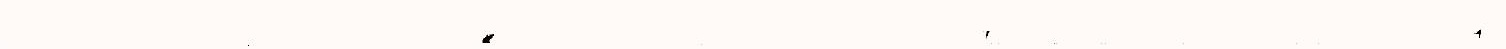




\title{
NEW MOLLUSCAN ASSEMBLAGES FROM THE UPPER MEMBER OF THE TWIN RIVER FORMATION, WESTERN WASHINGTON: SIGNIFICANCE IN NEOGENE CHRONOSTRATIGRAPHY
}

\author{
By WARREN O. ADDICOTT, ${ }^{1}$ Menlo Park and Stanford, Calif.
}

\begin{abstract}
New molluscan assemblages of provincial early Miocene age from a previously unrecognized fossiliferous interval of 400 to 500 metres in the uppermost part of the Twin River Formation, western Washington, are referable to the upper part of the "Blakeley" [or Matlockian] Stage. The new biostratigraphic data provide, for the first time, definition of the uppermost part of the "Blakeley" Stage and the boundary between it and an unnamed stage of late early Miocene age represented by the Clallam Formation and its megafauna. In contradistinction to earlier studies, the upper boundary of the "Blakeley" Stage does not coincide with the upper boundary of the Zemorrian Stage of the foraminiferal chronology, the "Blakeley" boundary being at least $45 \mathrm{~m}$ higher and possibly much more. Nearly 60 species of mollusks from the upper few hundred metres of the Twin River Formation are recognized herein, and 40 of these are illustrated. Six species are previously undescribed.
\end{abstract}

The Twin River Formation is a thick sequence of fine-grained marine clastic sedimentary rocks of Eocene to early Miocene age exposed along the north margin of the Olympic Peninsula, western Washington. New collections of marine mollusks from the uppermost 400 to 500 metres of the upper member of the Twin River, an interval from which in situ molluscan assemblages have not previously been recorded, bridge a conspicuous gap in the middle Tertiary megafaunal sequence of western Washington. This part of the Twin River Formation is of provincial early Miocene age. It overlies the highest stratigraphic occurrence of mollusks in the type section of Durham's (1944) Echinophoria apta zone but is within the stratigraphic interval originally designated by him. The $E$. apta zone has been taken as the standard for the upper half of the upper Oligocene and lower Miocene "Blakeley" Stage of Weaver and others (1944) [= Matlockian Stage of Armentrout (1975)]. It conformably underlies mollusk-bearing strata of the Clallam Formation, a sandstone and siltstone unit of late early Miocene provincial age (Addi-

\footnotetext{
1U.S. Geological Survey and Stanford University, Department of
Geology.
}

cott, 1975). These collections provide, for the first time, faunal definition of the upper boundary of the type sections of the E. apta zone and the "Blakeley" Stage. The upper limit of these coeval units is placed at the lithologic contact between the Twin River and Clallam Formations. This report documents the stratigraphic occurrence of these newly discovered assemblages, evaluates their biostratigraphic significance, and clarifies the position of the contact between the Twin River and the Clallam Formations.

After this manuscript was completed, Armentrout (1975) proposed the Matlockian Stage as a substitute name for the "Blakeley" Stage, basing his unit on exposures of the Lincoln Creek Formation along the Canyon River in southwestern Washington. "Blakeley" is retained herein for convenience in relating this discussion to the well-established, but less-desirable, informal biostratigraphic framework of northwestern Washington. This is not intended to cast doubt on the suitability of the newly proposed, typologically sound middle Tertiary stage that fills a long-standing need for formalized time-stratigraphic nomenclature.

Acknowledgments.-Weldon Rau examined foraminiferal samples collected from the upper member of the Twin River Formation during this study. Parke D. Snavely, Jr., and Howard Gower made available unpublished geologic mapping. Material from the Stanford University collections was made available by $\mathbf{A}$. Myra Keen. Photography of fossils is by Kenji Sakamoto.

\section{STRATIGRAPHY}

The Twin River Formation was originally defined by Arnold and Hannibal (1913) and subsequently redefined by Brown and Gower (1958) to include upper Eocene, Oligocene, and lower Miocene( ?) strata on the north flank of the Olympic Mountains (fig. 1) totaling about 5,000 to $6,000 \mathrm{~m}$ in thickness. In the type locality 


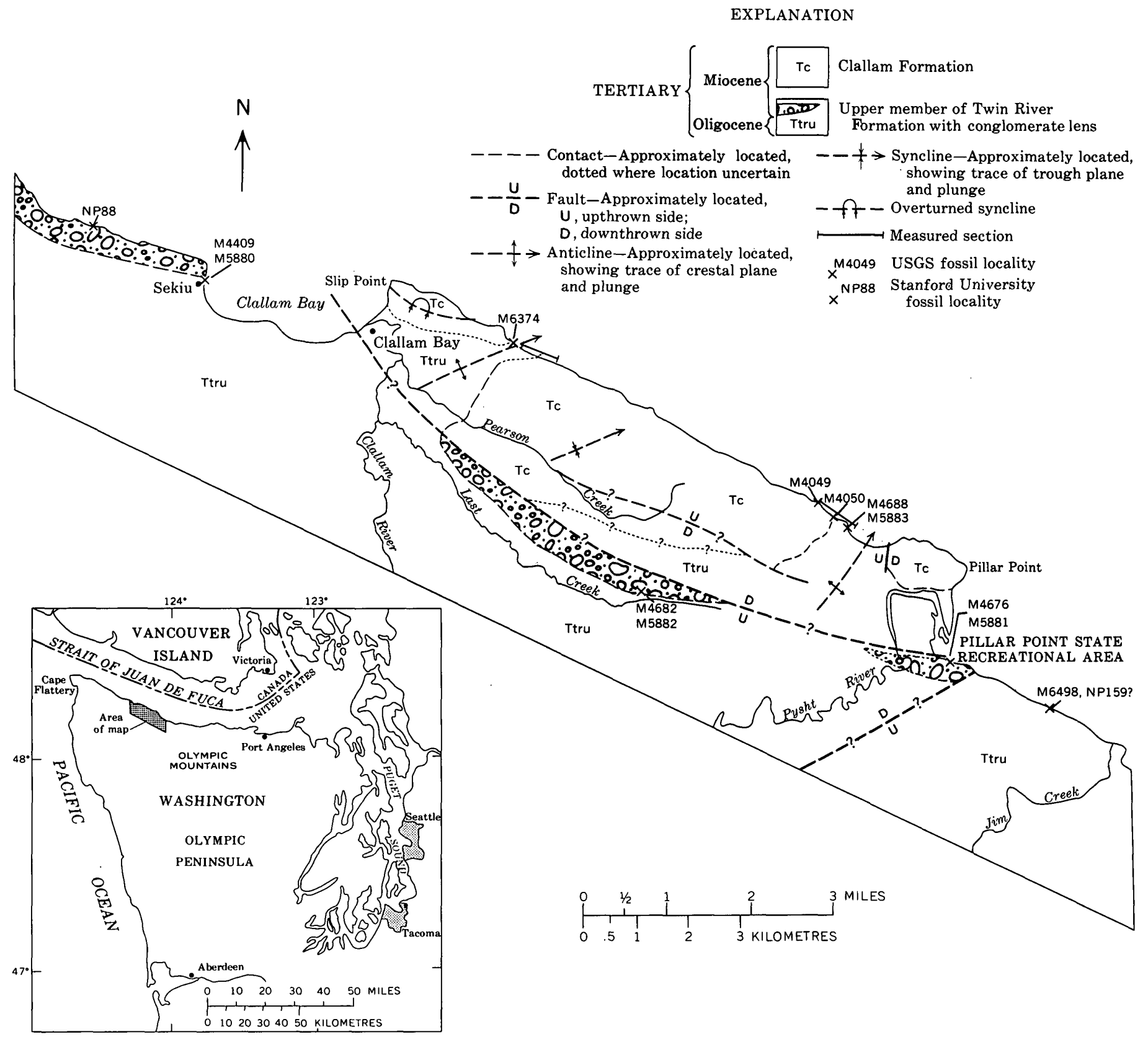

FIGURE 1.-Index map showing fossil localities in the upper few hundred metres of the upper member of the Twin River Formation along the north margin of the Olympic Peninsula, Washington. Generalized geology is from Gower (1960) with subsequent modification by Gower and P. D. Snavely, Jr. (written commun., January 1975).

of the Twin River Formation along Deep Creek, about $3 \mathrm{~km}$ east of Jim Creek, only the lowest $900 \mathrm{~m}$ of concretionary gray mudstone and intercalated very finegrained calcareous sandstone of the upper member is exposed (Brown and Gower, 1958). Exposures of this part of the upper member from Deep Creek eastward to near the mouth of East Twin River, a distance of about $8 \mathrm{~km}$, constitute the fossiliferous part of the type section of the Echinophoria apta zone (Durham, 1944, fig. 6). The conformable contact with the overlying
Clallam Formation is exposed in the more structurally complex area between the mouth of Deep Creek and Clallam Bay, about $20 \mathrm{~km}$ farther west. Revised mapping of the uppermost part of the Twin River Formation in the Pysht and Clallam Bay quadrangles by H. D. Gower and P. D. Snavely, Jr. (written commun., January 1975) places a conglomerate and sandstone unit, once included in the Clallam Formation (Weaver, 1937; Gower, 1960), in the upper part of the Twin River (fig. 2). Recent mapping in the Clallam Bay 


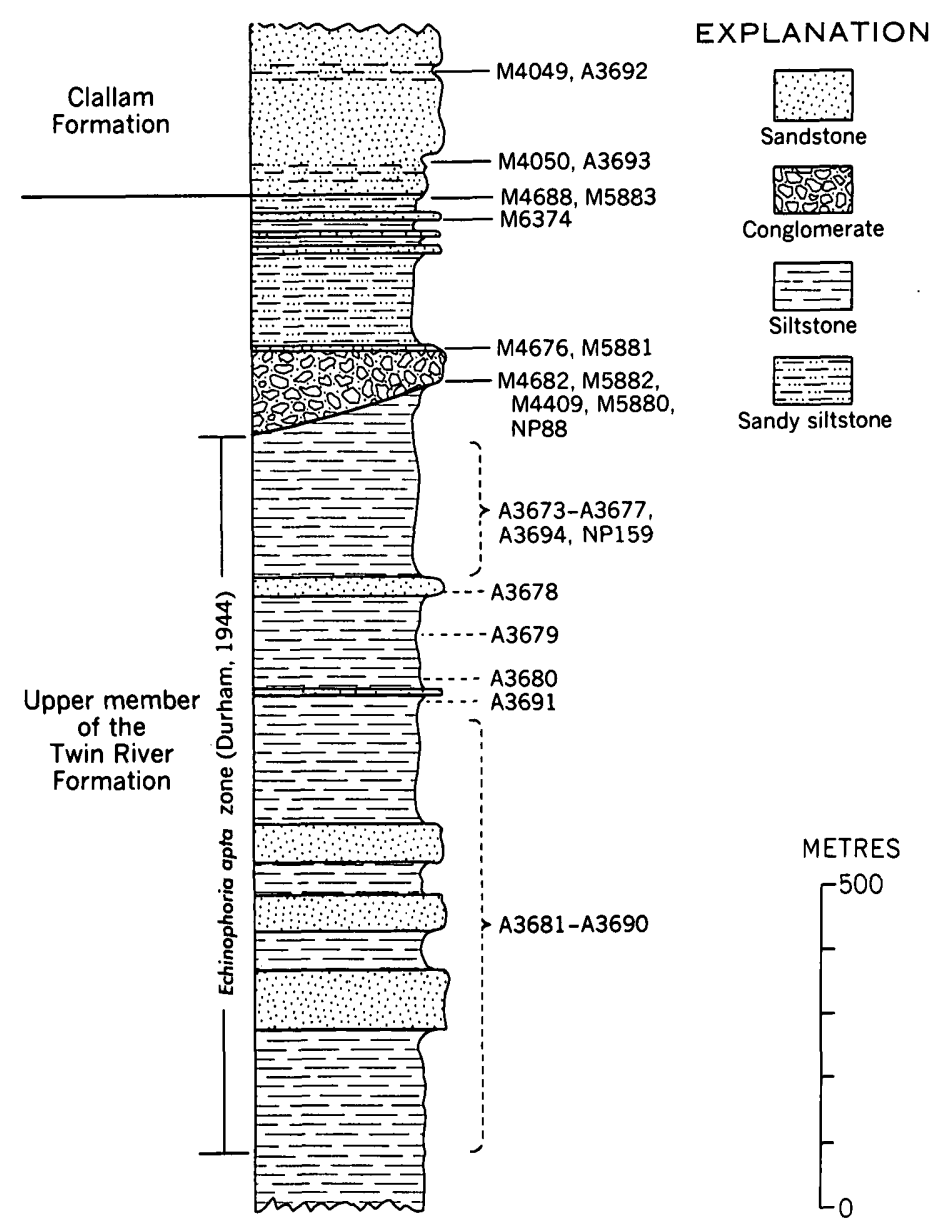

Fraure 2.-Generalized stratigraphic section of the upper member of the Twin River Formation and lower part of the Clallam Formation showing relative position of fossil localities. Compiled, in part, from Brown and Gower (1958) and Gower (1960). Stratigraphic position of localities is from Durham (1944). Collections with an $M$ prefix are housed at the U.S. Geological Survey, Menlo Park, Calif; those with an $A$ prefix are at the Museum of Paleontology, University of California, Berkeley; and those with an NP prefix are at Stanford University, Stanford, Calif.

quadrangle by Snavely and Norman MacLeod shows that this intraformational conglomerate is overlain by and interfingers with mudstone of the upper member of the Twin River. The conglomerate differs from pebble conglomerate of the Clallam Formation by the presence of white silicic volcanic and fossiliferous sandstone clasts.

The thickness of the sequence above the base of the conglomerate and sandstone unit near the top of the Twin River (fig. 2) is conjectural. The maximum thickness used -400 to $500 \mathrm{~m}$-is taken from mapping in the western part of the Pysht quadrangle (Gower, 1960) with the base of the Clallam positioned along the uppermost reaches of Pearson Creek rather than at the base of the prominent ridge-forming conglom- erate almost $1 \mathrm{~km}$ to the south. Strata south of Pearson Creek once mapped as Clallam Formation. (Gower, 1960) have been shown by subsequent work (Gower and P. D. Snavely, Jr., written commun., January 1975) to correlate with the upper member of the Twin River Formation.

The conformable contact between the Twin River Formation and the overlying Clallam Formation is well exposed in the intertidal zone near Pillar Point and Slip Point (fig. 1). The contact between these two formations was regarded as unconformable in some older reports (Weaver, 1937, 1942; Weaver and others, 1944; Durham, 1944), presumably because of the miscorrelation of the Clallam Formation with provincial middle Miocene formations along the Pacific Coast. The older usage is contrasted with stratigraphic and age revisions by Gower (1960) and Addicott (1975) in figure 3.

The upper 400 to $500 \mathrm{~m}$ of the upper member of the Twin River Formation consists of siltstone and silty sandstone with an interbedded lens of conglomerate (fig. 2). The siltstone is best exposed where the anticlines near Pillar Point and Slip Point intersect the coastline (fig. 1). The conglomerate and sandstone unit is exposed along a prominent topographic ridge south of Pearson Creek (fig. 1) and in a quarry and adjacent low sea cliff directly east of the mouth of Pysht River.

\section{BIOSTRATIGRAPHY}

Marine megafossils occur in the conglomerate, in sandstone at the top of the conglomerate unit, and in

\begin{tabular}{|c|c|c|c|c|c|}
\hline $\begin{array}{l}\text { Provincial } \\
\text { series }\end{array}$ & & $\begin{array}{l}\text { Arnold and } \\
\text { Hannibal } \\
\text { (1913) }\end{array}$ & $\begin{array}{l}\text { Weaver and } \\
\text { others } \\
(1944)\end{array}$ & $\begin{array}{l}\text { Brown and } \\
\text { Gower (1958) } \\
\text { and Gower } \\
(1960)\end{array}$ & $\begin{array}{l}\text { This } \\
\text { report }\end{array}$ \\
\hline $\begin{array}{l}\text { Middle } \\
\text { Miocene }\end{array}$ & & $\begin{array}{l}\text { Monterey } \\
\text { gormation }\end{array}$ & $\begin{array}{l}\text { Astoria } \\
\text { Formation }\end{array}$ & $\begin{array}{l}\text { Clallam } \\
\text { Formation }\end{array}$ & \\
\hline Lower & \multirow{3}{*}{ 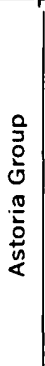 } & & & \multirow{3}{*}{$\begin{array}{c}\text { Twin River } \\
\text { Formation, } \\
\text { upper } \\
\text { member }\end{array}$} & $\begin{array}{l}\text { Clallam } \\
\text { Formation }\end{array}$ \\
\hline & & \begin{tabular}{|l} 
Twin River \\
Formation
\end{tabular} & & & \multirow[b]{2}{*}{$\begin{array}{c}\text { Twin River } \\
\text { Formation, } \\
\text { upper } \\
\text { member }\end{array}$} \\
\hline $\begin{array}{c}\text { Upper } \\
\text { Oligocene }\end{array}$ & & $\begin{array}{c}---?--- \\
\text { Seattle } \\
\text { Formation }\end{array}$ & $\begin{array}{l}\text { Twin } \\
\text { Rivers } \\
\text { Formation }\end{array}$ & & \\
\hline
\end{tabular}

Figure 3.-Correlation of nomenclature of this report with earlier reports showing reassignment of the Clallam Formation to the provincial lower Miocene (Addicott, 1975). 
siltstone in the uppermost $30-40 \mathrm{~m}$ of the formation. The fossils in the conglomerate are from redeposited sandstone boulders. These scattered molluscan assemblages have not previously been considered in the middle Tertiary biostratigraphy of the northern margin of the Olympic Peninsula. They overly the highest strata included in the type section of the Echinophoria apta zone by Durham (1944) and conformably underly the lowest fossiliferous strata of the lower Miocene Clallam Formation (Durham, 1944, loc. A3693; Addicott, 1975). Two mud pectens, Propeamussium clallamensis (Arnold, 1905) and $P$. pillarense (Slodkewitsch, 1938), had previously been described from this area"one and one-half miles east of Pillar Point" (Arnold, 1905 , p. 58). Arnold and Hannibal (1913, p. 584, loc. NP 159) listed these pectinids [as Pecten peckhami Gabb] together with six other mollusks including Aturia angustata (Conrad), Acila gettysburgensis (Reagan), and Eudolium petrosum Conrad [Liracassis apta (Tegland)] from this locality. Their locality lies east of the northwest-trending fault that intersects the shoreline near Pillar Point State Recreational Area (fig. 1). It is presumed to be stratigraphically lower than the new localities treated in this report and at, or near, the top of Durham's (1944) Echinophoria apta zone (fig. 2) although it was not considered in his definition of this zone. A recently collected assemblage from what is here regarded as the same locality (loc. M6498; fig. 1) includes Acila gettysburgensis (Reagan), Opalia cf. O. williamsoni (Anderson and Martin), Priscofusus stewarti (Tegland), and Dentalium pseudonyma Pilsbry and Sharp.

\section{Unnamed conglomerate and sandstone}

Boulder and cobble conglomerate in the upper member of the Twin River Formation contains scattered fossiliferous sandstone clasts that have yielded a moderately diverse molluscan fauna. This conglomerate and interbedded sandstone form a prominent strike ridge which is parallel to Last Creek between Clallam Bay and Pillar Point (fig. 1) and is locally referred to as conglomerate ridge. Conglomerate is also exposed along the shoreline and in an abandoned quarry adjacent to State Route $9 \mathrm{~A}$, about $0.5 \mathrm{~km}$ west of Pillar Point State Recreational Area. In these areas it was mapped as the basal part of the Clallam Formation by Gower (1960) and is about $1,000 \mathrm{~m}$ above the base of the upper member of the Twin River Formation (Brown and Gower, 1958, p. 2509). Subsequent unpublished work in this area and farther west between Sekiu and the mouth of Hoko River by P. D. Snavely and N. S. MacLeod, however, has shown that this conglomerate is within the upper member of the Twin River Formation, stratigraphically below the Clallam Formation.
The conglomerate strikes eastward offshore near Pillar Point State Recreational Area about $2 \mathrm{~km}$ south of Pillar Point (fig. 1) where it is capped by a fossiliferous sandstone containing a poorly preserved "Blakeley" assemblage (M4676 and M5881). Because the conglomerate and sandstone unit does not reappear on land farther to the east, it is believed to be stratigraphically higher than localities in the type section of the upper "Blakeley" Echinophoria apta zone of Durham (1944). Generally poor exposures of siltstone and mudstone of the upper part of the Twin River Formation east of the Pillar Point area together with folds and minor faults (Weaver, 1937; Brown and others, 1960) make it impossible to determine with precision the stratigraphic interval between the conglomerate and the key assemblage (UCMP A3678) from the type section of Durham's (1944) E. apta zone near the mouth of East Twin River. The locality at East Twin River (UCMP A3678) is doubtfully placed several hundred metres above the base of the E. apta zone, very near the top of the Twin River Formation by Durham (1944, fig. 5). Subsequent mapping by Brown and Gower (1958), however, places this locality much lower-about 150 to $300 \mathrm{~m}$ above the base of the E. apta zone.

The reworked assemblage from this conglomerate, listed below, is clearly referable to the upper part of the "Blakeley" Stage and is of provincial early Miocene age (USGS locs. M4409, M4682, M5880, and M5882; Stanford University loc. NP88).

Gastropods :

Ancistrolepis sp.

Bruclarkia acuminata (Anderson and Martin)

(fig. 6a)

Crepidula sp.

Neverita (Glossaulax) sp. (fig. 6h)

Polinices sp. (fig. $6 \mathrm{~m}$ )

Priscofusus hannibali (Clark and Arnold) (figs. $6 g, 6 l, 6 p)$

Trichotropis n. sp. aff. T. goweri Addicott (fig. $6 k)$

Pelecypods:

Acila muta Clark (fig. 6d)

Anadara sp.

Clinocardium sookensis (Clark and Arnold)

Felaniella parilis (Conrad) (fig. 6i)

Katherinella sp.

Lucinoma acutilineata (Conrad)

Macoma cf. M. twinensis Clark

Mytilus cf. M. sammamishensis Weaver (fig. 6b)

Panopea abrupta (Conrad)

Securella cryptolineata (Clark) (fig. $6 n$ )

Solen cf. S. clallamensis Clark and Arnold (fig. $6 c)$ 
Pelecypods-Continued

Solen cf. S. conradi Dall (fig. 6o)

Spisula albaria (Conrad)

Spisula hannibali Clark and Arnold

Tellina emacerata Conrad (fig. 6e)

Thracia schencki Tegland

Yoldia tenuissima Clark (fig. $6 j$ )

Scaphopod:

Dentalium pseudonyma Pilsbry and Sharp (fig. $6 f$ ) Species such as Bruclarkia acuminata, Priscofusus hannibali, Clinocardium sookensis, and Acila muta are restricted, for example, to the upper part of the "Blakeley" Stage, the regional standard for the lower part of the early Miocene. Other doubtfully identified species lend support to this correlation.

The post-late Oligocene provincial age of this assemblage is noteworthy because it shows that there was no appreciable time gap between the original deposition of these fossils and their reincorporation as boulders in the Twin River Formation. In other words, the late Oligocene early "Blakeley" age of the stratigraphically lower part of this member of the Twin River (Durham, 1944) indicates that these recycled early Miocene fossils were ripped up and then redeposited within a relatively short period of time.

A small assemblage of autochthonous mollusks has been collected from sandstone immediately overlying this conglomerate near the mouth of Pysht River (USGS locs. M4676 and M5881).

Gastropods:

Bathybembix n. sp.? aff. B. arnoldi (Durham) figs. $6 u, 6 w)$

Bruclarkia cf. B. acuminata (Anderson and Martin) (figs. $6 q, 6 r$ )

Cancellaria or Admete (fig. 6t)

Cerithium newocombei (Clark and Arnold)?

Naticid

?Perse sp.

Priscofusus cf. P. hannibali (Clark and Arnold) (fig. 6s)

Pelecypods:

Acesta n. sp. (figs. $6 x, 6 z, 6 a b$ )

Acesta cf. A. oakvillensis Clark (figs. 6ac)

?Megayoldia sp.

Pectinid (fig. 6v)

?Pitar sp.

Portlandia cf. P. blakeleyensis (Durham) (fig. 6y) Spisula sp.

Scaphopod:

Dentalium sp.

Brachiopod:

Laqueus cf. L. vancouveriensis Davidson (fig. 6aa)
These species are preserved as molds in a deeply weathered, friable sandstone and are, therefore, provisionally identified. Nevertheless, those specimens that can be closely compared with named taxa-Bruclarkia cf. $B$. acuminata, Priscofusus cf. P. hannibali, and Portlandia cf. $P$. blakeleyensis-collectively suggest assignment to the upper part of the "Blakeley" Stage and a provincial early Miocene age. They do not indicate an appreciable difference in age from the recycled molluscan fauna collected from the basal part of the underlying conglomerate, and they are clearly older than the diverse molluscan fauna of the overlying Clallam Formation. The generic composition of this small assemblage does, however, suggest a deeper water facies. Genera of deeper water aspect are Bathybembix, Acesta, and Portlandia. These are suggestive of outer sublittoral or possibly upper bathyal depths.

\section{Uppermost siltstone}

Two assemblages occur in shoreline exposures of the uppermost 30 to $40 \mathrm{~m}$ of the Twin River Formation (fig. 4) between Pillar Point and Slip Point (USGS locs. M4688 and M6374; fig. 1). The 23 species from these assemblages are primarily taxa that range into stratigraphically lower and higher parts of the middle Tertiary sequence (table 1). Three species in these small assemblages are restricted to the uppermost part of the Twin River Formation: Nucula n. sp. (fig. $7 b$, $7 d, 7 g$ ), Cancellaria n. sp. aff. C. keenae (fig. $7 y$ ), and T'urritella yaquinana. Of these, only $T$. yaquinana occurs in other formations. There are, however, a number of species, some provisionally identified, whose stratigraphic ranges overlap in the upper part of the "Blakeley" Stage (table 1). The co-occurrence of the following taxa is, therefore, considered indicative of an early Miocene provincial age and of assignment to the upper part of the "Blakeley" Stage: Bruclarkia cf. B. yaquinana (fig. 7e), Cancellaria weaveri (fig. $7 v$, $7 w$ ), Megasurcula wynoocheensis (fig. $7 t, 7 u$ ), Perse teglandae (fig. 7o), Polinices blakeleyensis (fig. 7z), Spirotropis calodius (fig. $7 x$ ), Katherinella etheringtoni (fig. $7 a, i$ ), Litorhadia astoriana (fig. $7 p$ ), $M a-$ coma arnoldi (fig. $7 q, r$ ), and Dentalium n. sp. (table 1). It should be emphasized, however, that the stratigraphic affinities of this assemblage are diffioult to determine owing, in part, to its small size. There are distinct faunal affinities with assemblages from the overlying Clallam Formation, but several species are not known to range upward into that formation nor do they occur in coeval strata elsewhere (table 1).

\section{BENTHONIC FORAMINIFERAL DATA}

Study of benthonic foraminifers from measured sections on the west flank of the anticline near Pillar 
TABLE 1.-Mollusks from near the top of the upper member of the Twin River Formation between Pillar Point and slip Point (USGS loc. M4688, M5883, and M6874) [Segments of ranges depicted by broken lines indicate newly reported range extensions. Molluscan stages are from Weaver and others (1941)
and Armentrout (1975)]

\begin{tabular}{|c|c|c|c|c|}
\hline \multirow{3}{*}{$\begin{array}{l}\text { Formation } \\
\text { Benthonic foraminiferal stage }\end{array}$} & \multicolumn{2}{|c|}{ Twin River Formation } & $\begin{array}{c}\text { Clallam } \\
\text { Formation }\end{array}$ & $\begin{array}{c}\text { Astoria } \\
\text { Formation }\end{array}$ \\
\hline & \multicolumn{2}{|c|}{ Zemorrian } & \multicolumn{2}{|c|}{ Saucesian } \\
\hline & Lower & Upper & Lower & Upper \\
\hline \multirow{2}{*}{$\begin{array}{l}\text { Molluscan range zone } \\
\text { Molluscan stage }\end{array}$} & $\begin{array}{c}\text { Echinophoria } \\
\text { rex }\end{array}$ & $\begin{array}{l}\text { Echinophoria } \\
\text { apta }\end{array}$ & $\begin{array}{l}\text { Vertipecten } \\
\text { fucanus }\end{array}$ & $\begin{array}{l}\text { Patinopecten } \\
\text { propatulus }\end{array}$ \\
\hline & \multicolumn{2}{|c|}{$\begin{array}{l}\text { "Blakeley" } \\
\text { Matlockian }\end{array}$} & Unnamed & Unnamed \\
\hline \\
\hline & & & & \\
\hline \multicolumn{5}{|l|}{$\begin{array}{l}\text { Polinices blakeleyensis Tegland (fig. } 7 z) \\
\text { Priscofusus n. sp. aff. } P \text {. geniculus (Conrad) (figs. } \\
\text { 7aa, } 7 a b) \\
\text { Spirotropis calodius Moore (fig. } 7 x \text { ) } \\
\text { Sinum scopulosum (Conrad) }\end{array}$} \\
\hline \multirow{2}{*}{\multicolumn{5}{|c|}{$\begin{array}{l}\text { Sinum scopulosum (Conrad) } \\
\text { Turritella yaquinana Addicott }\end{array}$}} \\
\hline \multirow{3}{*}{\multicolumn{5}{|c|}{$\begin{array}{l}\text { Pelecypods: } \\
\text { Acila gettysburgensis (Reagan) (fig. } 7 c \text { ) } \\
\text { Archarax dalli (Clark) (figs. 7f, } 7 h, 7 m \text { ) } \\
\text { Conchocele bisecta (Conrad) (fig. } 7 j \text { ) }\end{array}$}} \\
\hline & & & & \\
\hline & & & & \\
\hline \multicolumn{5}{|l|}{$\begin{array}{l}\text { Katherinella etheringtoni (Tegland) (figs. 7a, 7i) } \\
\text { Litorhadia astoriana (Henderson) (fig. } 7 p \text { ) }\end{array}$} \\
\hline $\begin{array}{l}\text { Macoma twinensis Clark (figs. } 7 l, 7 n) \\
\text { Lucinoma acutilineata (Conrad) (flg. } 7 k \text { ) }\end{array}$ & & & & \\
\hline \multirow{2}{*}{\multicolumn{5}{|c|}{$\begin{array}{l}\text { Thracia schencki Tegland } \\
\text { Securella }\end{array}$}} \\
\hline & & & & \\
\hline $\begin{array}{l}\text { Scaphopod : } \\
\text { Dentalium n. sp. }\end{array}$ & & & & \\
\hline
\end{tabular}

Point and on the east flank of the anticline near Slip Point by Weldon Rau (written commun., December 27,1974 ) indicates that the highest $45 \mathrm{~m}$ of the upper member of the Twin River Formation is of Saucesian age. Two samples from this interval (USGS locs. Mf2399 and Mf2401) contain Nonion costiferum (Cushman) which is not known to occur in preSaucesian strata in western Washington. Several other samples from the uppermost $145 \mathrm{~m}$ of the Twin River Formation in these sections contain small assemblages (10 species or fewer per sample) that are considered by Rau to be of either Zemorrian or Saucesian age (table 2). Commonly occurring species in these Zemorrian or Saucesian assemblages from near the top of the Twin River Formation are Cassidulina crassipunctata Cushman and Hobson, Elphidium cf. E. minutum (Reuss), Gyroidina orbicularis planata Cushman, Nonion incisum (Cushman), and Nonionella miocenica Cushman.

Prior to his study of these samples, Rau (1964, fig. 1) had placed the Zemorrian-Saucesian boundary at the base of the Clallam Formation. It now appears that the boundary falls within the upper part of the upper member of the underlying Twin River Formation, at least about $45 \mathrm{~m}$ below the top of the member and possibly more than $145 \mathrm{~m}$ below the top.

\section{SUMMARY AND CONCLUSIONS}

The 400- to 500-m interval at the top of the upper member of the Twin River Formation containing the new molluscan assemblages overlies the fossiliferous part of the originally defined type section of the Echinophoria apta zone. The concurrent ranges of several mollusks in these assemblages suggest assignment to the $E$. apta zone and the coeval upper part of the "Blakeley" [ = Matlockian] Stage. Liracassis [=Echinophoria of authors] apta, the zonal index species, is not known to occur in this stratigraphic interval nor is the genus known from the overlying Clallam Formation (Addicott, 1976). Nevertheless, these strata are assigned to the $E$. apta zone because of their faunal affinities to that unit. The absence of Liracassis, a moderately deepwater genus, is believed to be a function of the relatively shallow-water depositional environment which excluded such outer sublittoral to bathyal mollusks. The strata containing the deeper water genera Bathybembix and Acesta are also characterized by coarser sediment textures than those in which $L$. apta is generally found. 
Pillar Point area

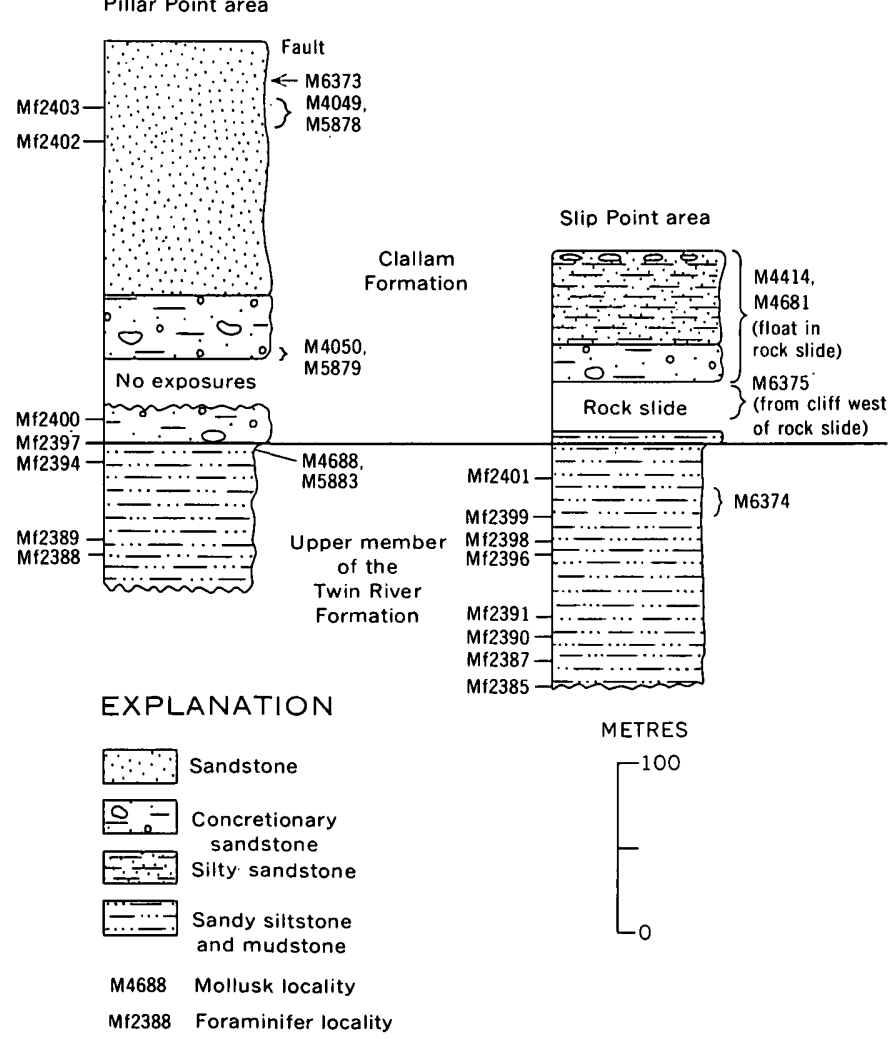

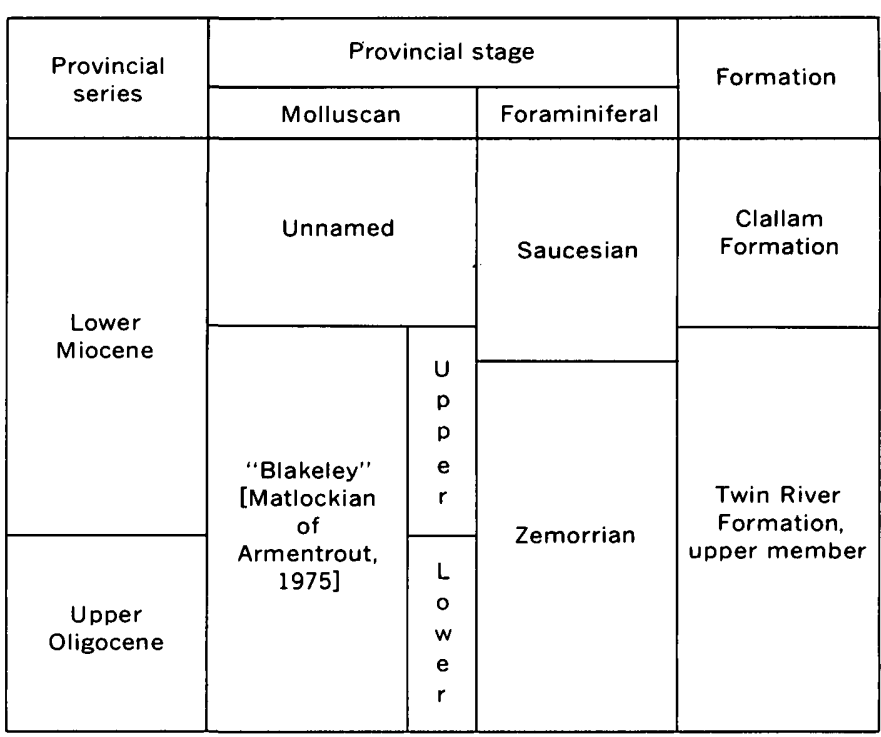

Figure 5.-Correlation of upper member of Twin River Formation. Placement of Oligocene-Miocene boundary is based on data considered by Addicott (1974).

Frgure 4.-Stratigraphic position of Twin River and Clallam mollusk and foraminifer localities in measured sections near Pillar Point and Slip Point.

TABLE 2.-Foraminifera from the upper part of the upper member of the Twin River Formation and basal part of the Clallam Formation near Slip Point and Pillar Point.

[Fossils Identified by W. W. Rau. Z, Zemorrian; S, Saucesian; C, common; F, few ; R, rare ; ?, questionably Identified]

\begin{tabular}{|c|c|c|c|c|c|c|c|c|c|c|c|c|c|c|c|}
\hline \multirow{4}{*}{ Species } & \multicolumn{8}{|c|}{$\begin{array}{l}\text { Slip Point } \\
\text { section }\end{array}$} & \multicolumn{7}{|c|}{$\begin{array}{l}\text { Pillar Point } \\
\text { section }\end{array}$} \\
\hline & \multicolumn{6}{|c|}{$\mathrm{Z}$ or S Stage } & \multicolumn{2}{|c|}{$\begin{array}{c}\text { S } \\
\text { Stage }\end{array}$} & \multicolumn{6}{|c|}{ Z or S Stage } & \multirow[t]{2}{*}{$\begin{array}{c}\text { S } \\
\text { Stage }\end{array}$} \\
\hline & \multicolumn{14}{|c|}{ USGS locallties } & \\
\hline & 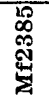 & 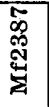 & 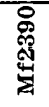 & 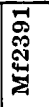 & 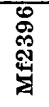 & 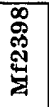 & $\begin{array}{l}\text { S } \\
\text { 岕 } \\
\text { 岁 }\end{array}$ & $\begin{array}{l}\overline{0} \\
\text { 离 } \\
\text { 茨 }\end{array}$ & 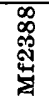 & 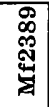 & $\begin{array}{l}\text { 茄 } \\
\text { 岁 } \\
\text { 岁 }\end{array}$ & 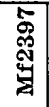 & 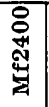 & 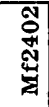 & 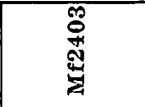 \\
\hline Entosolenia sp. Rau, 1964 & $\mathbf{R}$ & -- & $\mathbf{R}$ & - & & & & -- & -- & -- & -- & -- & $\mathbf{R}$ & -- & \\
\hline Pseudoglandulina aff. $P$. inflata (Bornemann) & $?$ & -- & - & $?$ & $\mathbf{R}$ & $\mathbf{F}$ & $\mathbf{R}$ & -- & -- & -- & $\mathbf{R}$ & -- & $\mathbf{R}$ & -- & \\
\hline Bulimina ovata d'Orbigny & ? & $?$ & $?$ & & & & -- & -- & -- & -- & $?$ & -- & $\mathbf{R}$ & $?$ & $?$ \\
\hline Nonion incisum (Cushman) -- & $\mathbf{C}$ & $\mathbf{C}$ & $\mathbf{C}$ & $\mathbf{C}$ & $\mathbf{F}$ & $\mathbf{F}$ & - & -- & $\mathbf{F}$ & $\mathbf{C}$ & $\mathbf{F}$ & & $\ldots$ & -- & - n- - - \\
\hline Cassidulina crassipunctata Cushman and Hobson & $\mathbf{F}$ & $\mathbf{F}$ & $\mathbf{C}$ & $\mathbf{F}$ & $\mathbf{F}$ & $\mathbf{C}$ & - & -- & $\mathbf{R}$ & $\mathbf{F}$ & $\mathbf{C}$ & $\mathbf{R}$ & $\mathbf{R}$ & - & \\
\hline Globigerina sp. & $\mathbf{R}$ & -- & -- & $\mathbf{R}$ & & -- & - & -- & -- & -- & -- & -- & -- & - & \\
\hline Elphidium cf. E. minutum (Reuss) & $\mathbf{C}$ & $\mathbf{R}$ & $\mathbf{R}$ & $\mathbf{F}$ & $\mathbf{C}$ & $\mathbf{F}$ & $\mathbf{F}$ & -- & $\mathbf{F}$ & $\mathbf{F}$ & $\mathbf{C}$ & $\mathbf{R}$ & $\mathbf{F}$ & $\mathbf{R}$ & \\
\hline Nonionella miocenica Cushman - & -- & -- & $\mathbf{F}$ & $\mathbf{R}$ & -- & -- & $\mathbf{R}$ & -- & -- & -- & -- & $\mathbf{R}$ & -- & -- & \\
\hline $\begin{array}{l}\text { Buccella mansfieldi oregonensis (Cushman, Stewart, and } \\
\text { Stewart) }\end{array}$ & -- & -- & $?$ & $\mathbf{F}$ & $\mathbf{F}$ & -- & $\mathbf{F}$ & $\mathbf{F}$ & $\mathbf{F}$ & -- & -- & --1 & -- & $\mathbf{R}$ & \\
\hline Dentalina sp. & - & -- & -- & $\mathbf{R}$ & -- & -- & -- & -- & -- & -- & -- & -- & - & - & \\
\hline Plectofrondicularia packardi multilineata Cushman and & & & & & & & & & & & & & & & \\
\hline Simonson & -- & -- & -- & $\mathbf{R}$ & & & $=-$ & -- & -- & $=-$ & - & -- & -- & -- & \\
\hline Gyroidina orbicularis planata Cushman & -- & -- & -- & - & $\mathbf{C}$ & $\mathbf{F}$ & $\mathbf{F}$ & -- & -- & $\mathbf{R}$ & $\mathbf{F}$ & -- & -- & -- & \\
\hline Plectofrondicularia aff. $P$. miocenica Cushman & -- & -- & - & - & $\mathbf{R}$ & -- & -- & -- & -- & -- & -- & -- & -- & - & \\
\hline Plectofrondicularia californica Cushman and Stew & - & -- & - & $-\infty$ & $\mathbf{R}$ & -- & -- & -- & -- & -- & -- & -- & -- & -- & \\
\hline Cibicides sp. & -- & -- & -- & -- & $\mathbf{R}$ & -- & -- & -- & -- & -- & -- & -- & $\mathbf{R}$ & $\therefore-$ & \\
\hline Nonion pompilioides (Fichtel and Moll) & -- & -- & -- & -- & -- & $\mathbf{R}$ & -- & -- & -- & $?$ & $\mathbf{F}$ & -- & $?$ & -- & -1 \\
\hline Lenticulina cf. L. inornata (d'Orbigny) & -- & -- & -- & - & -- & -- & $\mathbf{F}$ & -- & -- & -- & -- & -- & -- & -- & 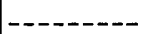 \\
\hline Lagena semistriata Williamson -- & - & $\ldots$ & - & - & -- & -- & $\mathbf{R}$ & $=$ & -- & -- & - & -- & -- & - & 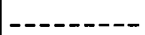 \\
\hline Nodogenerina advena Cushman and Laiming & -- & -- & -- & -- & -- & -- & $\mathbf{R}$ & - & -- & -- & -- & -- & $\ldots$ & $\ldots$ & \\
\hline Nonion costiferum (Cushman) & -- & - & -- & - & - & -- & $\mathbf{C}$ & $\mathbf{F}$ & -- & -- & -- & -- & - & - & $\mathbf{F}$ \\
\hline Bolivina cf. B. advena Cushman - & - & -- & - & - & - & - & $\mathbf{R}$ & -- & - & -- & $-\infty$ & -- & - & - & \\
\hline Quinqueloculina imperialis Hanna & - & -- & - & $1--$ & - & - & -- & $?$ & - & -- & - & - & - & - & $\mathbf{R}$ \\
\hline Quinquelnculina weaveri Rau & -- & & -- & -- & -- & -- & -- & $?$ & -- & -- & -- & -- & -- & -- & 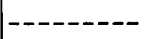 \\
\hline
\end{tabular}



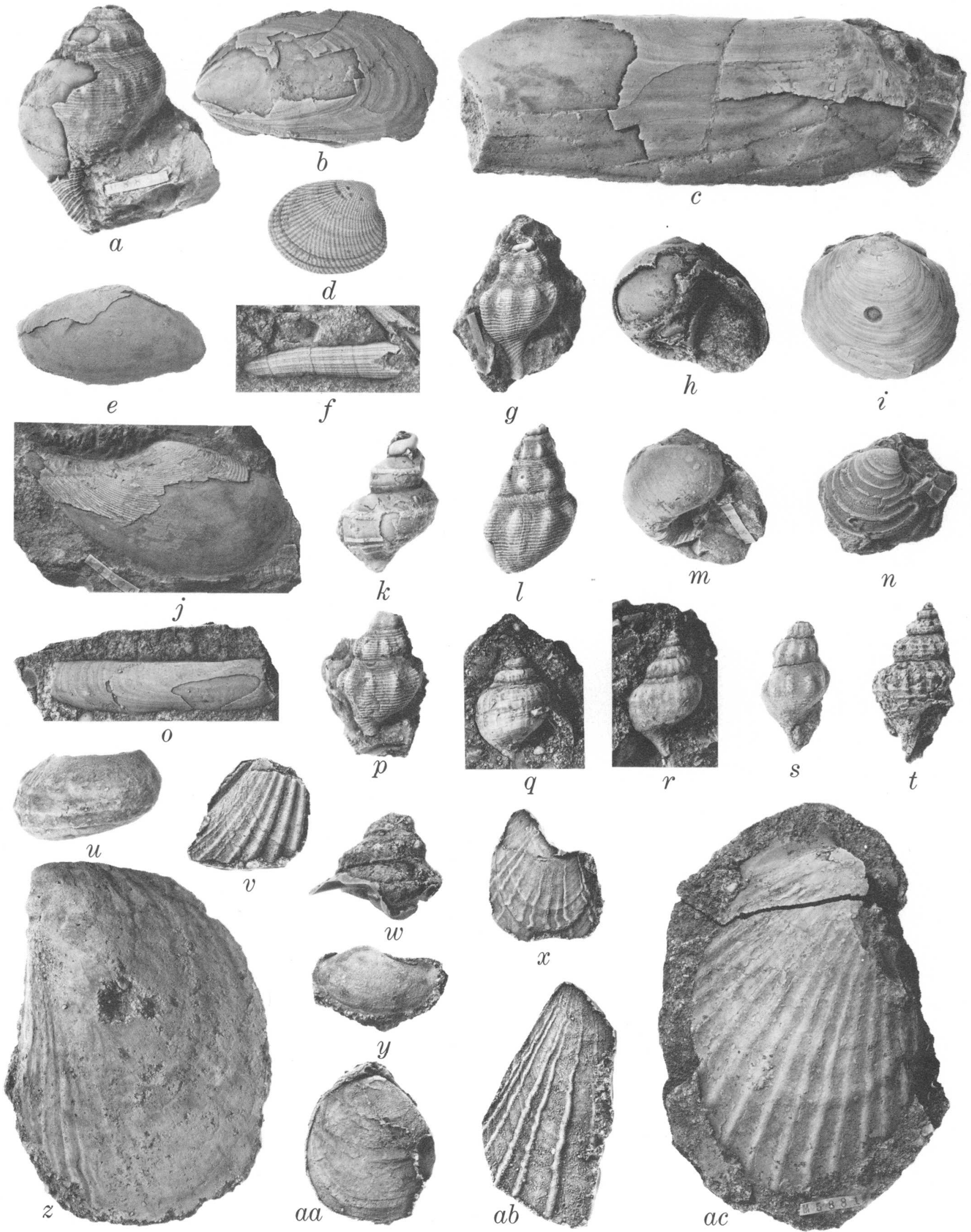
The data considered in this report indicate that the boundary between the lower Miocene part of the "Blakeley" Stage (the Echinophoria apta zone) and the overlying unnamed stage (Addicott, 1975) should be placed at the contact between the Twin River and Clallam Formations (fig. 5). New benthonic foraminiferal assemblages studied by Weldon Rau indicate that the boundary between the Zemorrian and Saucesian Stage does not, as previously believed (Rau, 1964), occur at this contact. Rather, it occurs in the uppermost part of the upper member of the Twin River Formation at least $45 \mathrm{~m}$ and possibly more than $145 \mathrm{~m}$ below the top. In contrast to earlier reports, it is apparent that the upper boundaries of the "Blakeley" and Zemorrian Stages are not coincident. Rather, the upper boundary of the "Blakeley" is at least $45 \mathrm{~m}$ higher in this area and could be much higher.
Fiaure 6.-Mollusks and brachiopod from the conglomerate near the top of the Twin River Formation (USGS locs. M4682, M5880, and M5882; Stanford Univ. loc. NP88) and from sandstone capping the conglomerate (USGS locs. M4676 and M5881). Specimens, natural size unless otherwise indicated in parentheses.

a. Bruclarkia acuminata (Anderson and Martin). USNM 219818, USGS loc. M5880.

b. Mytilus cf. M. sammamishensis Weaver. USNM 219819, USGS loc. M5880.

c. Solen cf. S. clallamensis Clark and Arnold. USNM 219820, USGS loc. M5880.

d. Acila muta Clark. USNM 219821, USGS loc. M4682. $(\times 2$.

e. Tellina emacerata Conrad. USNM 219822, USGS loc. M5880.

f. Dentalium pseudonyma Pilsbry and Sharp. SU 10234, SU loc. NP88.

g. Priscofusus hannibali (Clark and Arnold). USNM 219823, USGS loc. M5880.

h. Neverita (Glossaulax) sp. SU 10235, SU loc. NP88.

i. Felaniella parilis (Conrad). USNM 219824, USGS loc. M4682.

i. Yoldia tenuissima Clark. USNM 219825, USGS loc. M5880.

k. Trichotropis n. sp. aff. T. goweri Addicott. USNM 219826, USGS loc. M5882. ( $\times 2$.) l. Priscofusus hannibali (Clark and Arnold). SU 10236, SU loc. NP88.

m. Polinices sp. USNM 219827, USGS loc. M5880.

n. Securella cryptolineata (Clark). SU 10237, SU loc. NP88.

1. Solen cf. S. conradi Dall. USNM 219828, USGS loc. M4682.

p. Priscofusus hannibali (Clark and Arnold). USNM 219829, USGS loc. M5880.

q.r. Bruclarkia cf. B. acuminata (Anderson and Martin). USNM 219830 and 219831 , USGS loc. M4676.

*. Priscofusus cf. P. hannibali (Clark and Arnold), USNM 219832, USGS loc. M4676.

t. Cancellaria or Admete. USNM 219833, USGS loc. M4676. ( $\times 2$. $)$

u.u. Bathybemix n. sp.? aff. B. arnoldi (Durham). USNM 219834 and 219835, USGS loc. M4676. (Photograph of $w$ is $\times 1 \frac{1}{1}$.)

$v$ Pectinid. USNM 219836, USGS loc. M4676.

$x$ Acesta n. sp. USNM 219837, USGS loc. M5881.

11. Portlandia cf. P. blakeleyensis (Durham). USNM 219838, USGS loc. M4676.

2. Acesta n. sp. USNM 219839, USGS loc. M4676.

aa. Laqueus cf. $L$. vancouveriensis Davidson. USNM 219840, USGS loc. M5881. ( $\times 2$.)

ab. Acesta n. sp. USNM 219841, USGS loc. M4676.

ac. Acesta cf. A. oakvillensis Clark. USNM 219842, USGS loc. M5881. 

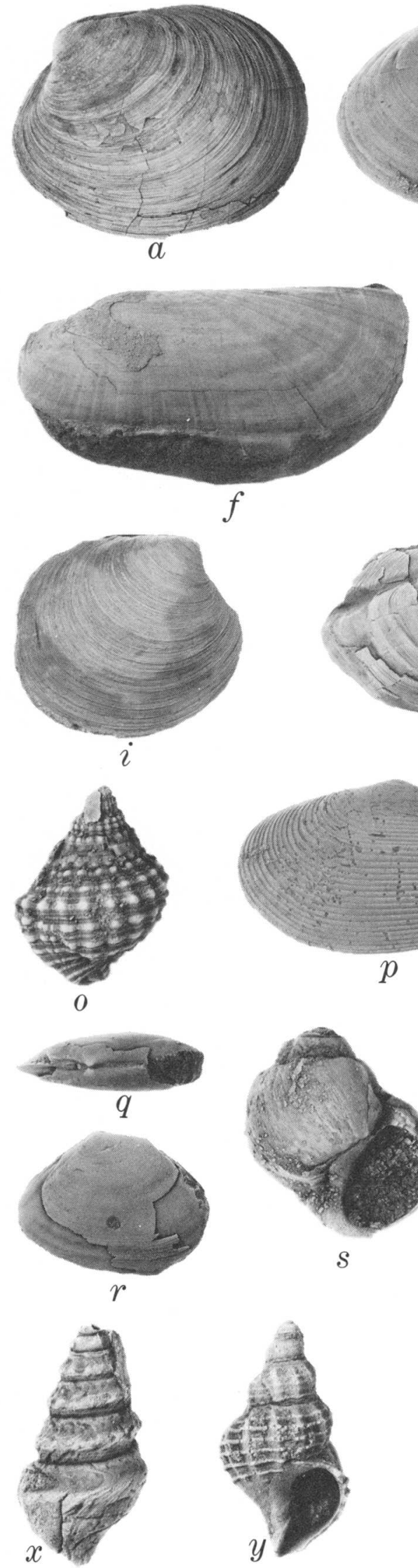

S

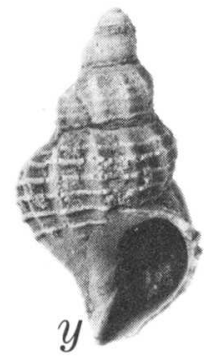

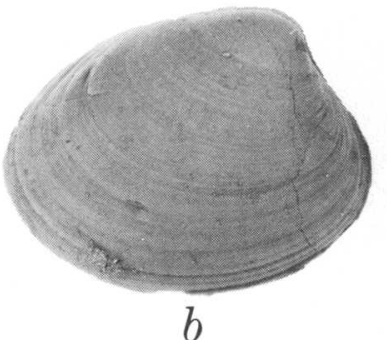
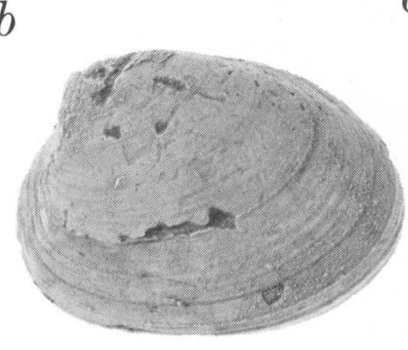

$g$
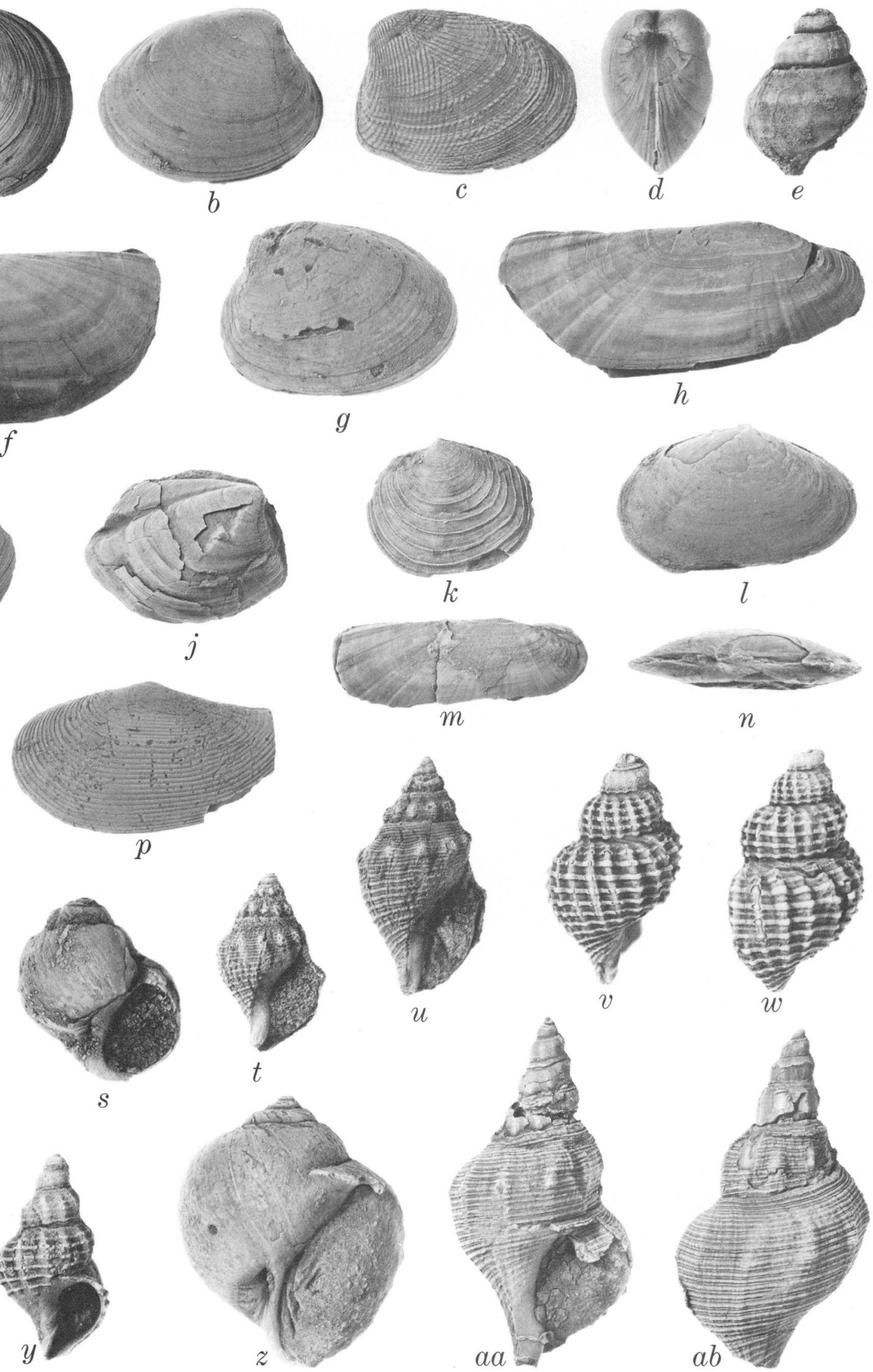
Figure 7.-Mollusks from siltstone at the top of the Twin River Formation (USGS locs. M4688, M5883, and M6374). Specimens, natural size unless otherwise indicated in parentheses.

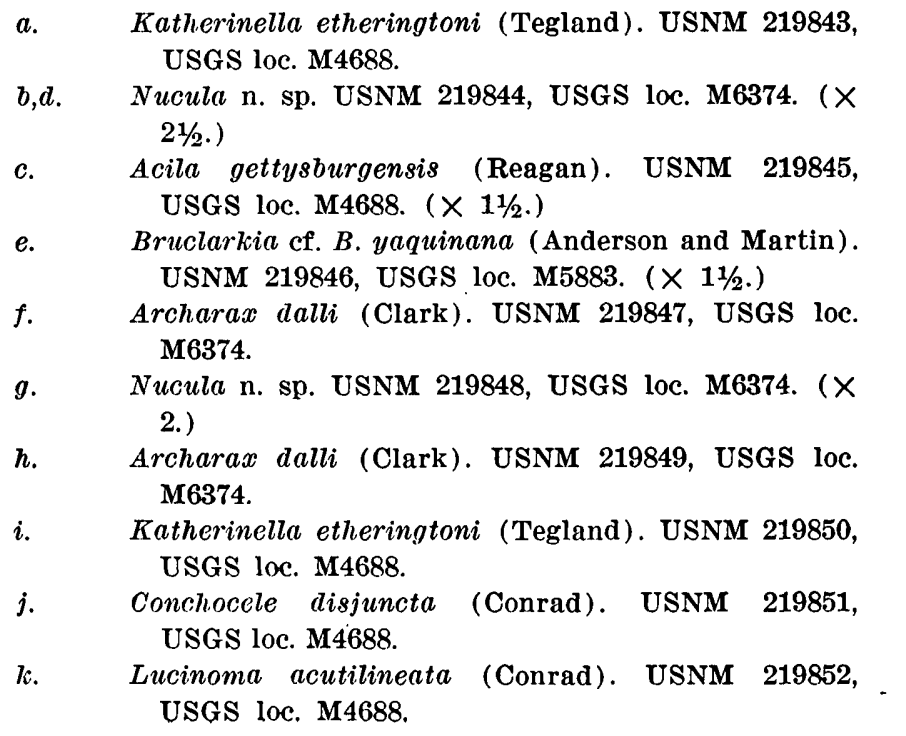

\author{
l,n. Macoma twinensis Clark. USNM 219853, USGS loc. \\ M5883. $\left(\times 1 \frac{1}{2}\right.$. $)$ \\ m. Archarax dalli (Clark). USNM 219854, USGS loc. \\ M6374. \\ o. Perse teglandae Durham. USNM 219855, USGS loc. \\ M4688. ( $\times 3$. $)$ \\ p. Lithorhadia astoriana (Henderson). USNM 219856, \\ USGS loc. M4688. ( $\times 2$.) \\ q,r. Macoma arnoldi Tegland. USNM 219857, USGS loc. \\ M4688. \\ s. Neverita sp. USNM 219858, USGS loc. M5883 ( $\quad 3$. $)$ \\ $t, u$. Megasurcula wynocheensis (Weaver). USNM 219859 \\ and 219860, USGS loc. M5883. ( $\times 2$.) \\ $v, w$. Cancellaria weaveri Etherington. USNM 219861, \\ USGS loc. M6374. ( $\times 2 \frac{1}{2}$.) \\ $x$. Spirotropis calodius Moore. USNM 219862, USGS \\ loc. M6374. $\left(\times 1 \frac{11}{2}\right.$.) \\ y. Cancellaria n. sp. aff. $C$. keenae Addicott. USNM \\ 219863, USGS loc. M4688. ( $\times 3$.) \\ z. Polinices blakeleyensis Tegland. USNM 219864, \\ USGS loc. M6374. $(\times 2$.) \\ aa,ab. Priscofusus n. sp. aff. P. geniculus (Conrad). USNM \\ 219865. USGS loc, M6374,
}

\section{REFERENCES CITED}

Addicott, W. O., 1974, Giant pectinids of the eastern North Pacific margin: significance in Neogene zoogeography and chronostratigraphy: Jour. Paleontology, v. 48, no. 1, p. 180-194, 2 pls.

1975, Provincial age and correlation of the Clallam Formation, northwestern Washington: Geol. Soc. America Abs. with Programs, v. 7, no. 3, p. 289.

_ 1976, Molluscan paleontology of the early Miocene Clallam Formation, northwestern Washington: U.S. Geol. Survey Prof. Paper 976. (In press.)

Armentrout, J. M., 1975, Molluscan biostratigraphy of the Lincoln Creek Formation, southwest Washington, in Weaver, D. W., and others, eds., Paleogene symposium and selected technical papers: Pacific Sec. Am. Assoc. Petroleum Geologists, Soc. Econ. Paleontologists and Mineralogists, Soc. Econ. Geophysicists Ann. Mtg., p. 14-48.

Arnold, Ralph, 1905, Coal in Clallam County, Washington : U.S. Geol. Survey Bull. 620, p. 413-421.

Arnold, Ralph, and Hannibal, Harold, 1913, The marine Tertiary stratigraphy of the north Pacific Coast of America: Am. Philos. Soc. Proc., v. 52, no. 212, p. 559-605.

Brown, R. D., Jr., and Gower, H. D., 1958, Twin River formation (redefinition), northern Olympic Peninsula, Washington: Am. Assoc. Petroleum Geologists Bull., v. 42, no. 10, p. 2492-2512.
Brown, R. D., Jr., Gower, H. D., and Snavely, P. D., Jr., 1960. Geology of the Port Angeles-Lake Crescent area, Clallam County, Washington: U.S. Geol. Survey Oil and Gas Inv. Map OM-203 [1961].

Durham, J. W., 1944, Megafaunal zones of the Oligocene of northwestern Washington: California Univ. Pubs., Dept. Geol. Sci. Bull., v. 27, no. 5, p. 101-211, pls. 13-18.

Gower, H. D., 1960, Geologic map of the Pysht quadrangle, Washington: U.S. Geol. Survey Geol. Quad. Map GQ-129, scale $1: 62,500$.

Rau, W. W., 1964, Foraminifera from the northern Olympic Peninsula, Washington: U.S. Geol. Survey Prof. Paper 374-G, p. G1-G33.

Slodkewitsch, W. S., 1938, Tertiary Pelecypoda from the Far East, v. 10, pt. 2 : USSR Acad. Sci., Paleont. Inst., Paleontology of USSR, v. 10, pt. 3, 275 p., 106 pls.

Weaver, C. E., 1937, Tertiary stratigraphy of western Washington and northwestern Oregon: Washington Univ. Pub. Geology, v. 4, 266 p.

- 1942, Paleontology of the marine Tertiary formations of Oregon and Washington: Seattle, Washington Univ. Pubs. Geology, v. 5, pts. 1-3, 789 p., 104 pls.

Weaver, C. E., Chm., and others (20), 1944, Correlation of the marine Cenozoic formations of western North America: Geol. Soc. America Bull., v. 55, no. 5, p. 569-598. 


\title{
MISSISSIPPIAN CARBONATE SHELF MARGINS, WESTERN UNITED STATES
}

\author{
By PETER R. ROSE, Denver, Colo.
}

\begin{abstract}
Regional linear carbonate shelf margins, or stratigraphic reefs, are postulated to have developed during Mississippian time along the eastern flank of the Cordilleran miogeosyncline in the Western United States. These shelf margins are analogous to well-documented ancient and modern geologic counterparts, such as the Guadalupian reef of the West Texas Permian basin, the Lower Cretaceous Edwards shelf margin of the Gulf Coast, and the modern Florida reef tract-Straits of Florida province. Two Mississippian shelf margins are believed to have existed: The lower one developed as an integral part of a widespread carbonate depositional complex of Kinderhookian through early Meramecian age; the upper shelf margin developed west of the earlier stratigraphic reef as part of a regional carbonate depositional complex of middle Meramecian to late Chesterian age. Evidence for both shelf margins consists of (1) a linear physical barrier, (2) restricted sediments in the shelf interior, (3) abrupt basinward thinning of sediments and basin-starvation just seaward of the shelf edge, (4) profound facies changes coincident with the basinward thinning-from light-colored, skeletal, shelf carbonate rocks to dark, fine-grained, silty, basinal carbonate rocks, and (5) the consistent regional occurrence of the first four patterns. Seaward topographic relief along the front edge of the lower shelf margin was probably about $200-400 \mathrm{~m}$, and maximum relief along the central sector of the upper shelf margin may have approached $1,000 \mathrm{~m}$.
\end{abstract}

In the Western United States, a widespread sheet of shallow-marine limestone and dolomite in the lower part of the Mississippian is present through much of the Rocky Mountain province and extends westward into the Cordilleran miogeosyncline. This succession comprises carbonate rocks of Kinderhookian, Osagean, and early Meramecian ages, and has many provincial rock-stratigraphic names, including Allan Mountain Limestone and Castle Reef Dolomite, Lodgepole and Mission Canyon Limestones, Madison Limestone or Group, Gardison and Deseret Limestones, and Leadville, Redwall, and Monte Cristo Limestones. For simplicity these rocks will be called the lower depositional complex throughout this report. Regionally, the lower depositional complex thickens westward from the Transcontinental arch of Eardley (1962), a persistent ancestral cratonic arch that stretches southwest across eastern South Dakota, Nebraska, and Colorado. West of the Wasatch line (Kay, 1951), in the Basin and
Range province, the carbonate part of the lower depositional complex thins markedly, and, farther west, the identity of the entire complex is lost in a flysch sequence.

Carbonate rocks of Late Mississippian age are also present in the Rocky Mountain and Great Basin regions, but they occupy a much narrower arcuate belt that stretches southeast across eastern Idaho and turns southwest across western Utah. These rocks, generally of middle Meramecian through Chesterian age, have been variously called the Great Blue, Ochre Mountain, Monroe Canvon, Brazer, and White Knob Limestones and the Scott Peak, South Creek, and Surrett Canyon Formations. In this report these Upper Mississippian rocks are included in the upper depositional complex, most of which lies west of the area where the carbonate part of the lower depositional complex is recognizable. Like the lower depositional complex, the upper depositional complex thickens westward into the Cordilleran geosyncline, and the carbonate component ultimately loses its identity in central Idaho and westernmost Utah.

Other thick and widespread carbonate sheets, such as the Guadalupian of West Texas and New Mexico or the Lower Cretaceous of northern Mexico and the Texas Gulf Coast, are distinguished by prominent and abrupt linear shelf margins-the stratigraphic reefs of Dunham (1970), which are sometimes termed "barrier reefs" or simply "reefs." These regional linear features represent the seaward limit of shallow-water carbonate accumulation, and the slope break just seaward represents the beginning of the fore-reef decline into a starved basin (Adams and others, 1951) deprived of substantial carbonate sediments. Such ancient shelf margins have their modern analogs among the reef tracts of Florida and the Bahamas, the Great Barrier Reef of Australia, and many other reef tracts throughout the world.

Recognition and delineation of ancient shelf margins are important, because they define depositional strike along basin flanks and strongly influence the character and orientation of adjacent petroleum-reservoir rocks and seals. Identification of carbonate shelf margins al- 
lows interpretation of the geometric arrangement and depositional mode of both shelf and basin sediments, as well as reliable estimation of ancient bathymetry and basin configuration. Thus, the accurately identified shelf margin may serve as a geologic keystone upon which the successful stratigraphic interpretation of the entire basin may rest.

\section{PURPOSE AND SCOPE}

This paper is a regional synthesis based on published surface information and available commercial subsurface logs. It considers the effect of two Mississippian shelf margins on stratigraphic nomenclature and on the geologic history of the Cordilleran miogeosyncline. The intent is ultimately to simplify regional Mississippian stratigraphic nomenclature. Finally, it outlines future research necesary to confirm the existence of these postulated shelf margins and locate them accurately.

\section{PREVIOUS WORK}

The Madison and its equivalents have widespread distribution, prominent topographic expression, and economic significance as aquifers, petroleum reservoirs, and sources of industrial stone. However, these units have not been considered previously as a complete regional carbonate depositional complex extending throughout the Western United States. Parts of the lower carbonate depositional complex have been analyzed in subregional studies by Andrichuk (1955), Sando and Dutro (1960), Sando (1967a, b; 1972, 1974), Craig (1972), Hintze (1973), and Gutschick (1976). Regional syntheses (Sando, 1976; Sando and others, 1975, 1976) for the Northern Rocky Mountains presented concepts similar to those presented herein, except for the postulation of substantial seaward topographic relief for the fronts of two carbonate shelf margins or reefs. These reports were not known to me until after my report was submitted for publication. The broad similarity of independently developed concepts lends support to the validity of the interpretations.

\section{SOURCES OF DATA AND ACKNOWLEDGMENTS}

This interpretation is based upon my review and synthesis of Mississippian stratigraphic columns presented in published reports of more than 100 outcrop areas, and of commercial sample logs for more than 120 wells throughout the Rocky Mountain and Cordilleran region. The location and references for each locality or well and the appropriate published references are given in a separate appendix (Rose, 1976).
I have made no attempt to adjust the maps to compensate for thrusting in the Sevier orogenic belt, except to indicate the probable prethrust position of the Antler orogenic belt and flysch trough in central Idaho. The original facies belts in western Wyoming, eastern Idaho, central Utah, and eastern Nevada, therefore, may have been wider than they are today.

This interpretation has developed over the past several years, partly through constructive discussions with colleagues such as C. A. Sandberg, F. G. Poole, and others who have been working on the Mississippian of the Western United States. Although the concepts presented here could not have evolved without their stimulation, the responsibility for stratigraphic correlations between wells and outcrop areas, the overall interpretation, and the resulting shelf-margin concept devolve solely upon me.

The existence of a starved basin in Utah and Idaho was suspected as early as 1969 by C. A. Sandberg on the basis of conodont samples from Laketown Canyon, Utah, that he processed and determined for A. E. Roberts (written communs. to A. E. Roberts and W. J. Sando, Mar. 26, 1969). Postulation of this starved basin, substantiated by later fieldwork, has been communicated by Sandberg in recent years through informal discussions and prepared talks.

\section{CONCEPTUAL MODEL OF CARBONATE DEPOSITION}

During the past 20 years, recognition of similar patterns of sedimentation among the more widely known modern carbonate depositional complexes and their ancient geologic counterparts has led to a generalized conceptual model useful in interpreting other carbonate successions. As the natural processes that control different sedimentary features have become better understood, stratigraphic responses to factors such as climate, geologic setting, and subsidence rate can often be predicted.

The literature pertaining to this carbonate depositional model is voluminous and will not be reviewed here, except to cite a few outstanding contributions. Rich (1951) defined three dominant environments of deposition as undaform, clinoform, and fondoform, which correspond geometrically to topset, foreset, and bottomset environments of deltaic sedimentation, and he recognized the general applicability of his model to most regional terrigenous and carbonate depositional systems. Work by King (1948), Adams, Frenzel, Rhodes, and Johnson (1951), Van Siclen (1958), Jackson (1964), and Meissner (1972) confirmed the applicability of Rich's concept in Pennsylvanian and 
Permian carbonate rocks of West Texas. Ginsburg (1956) and Imbrie and Purdy (1962) demonstrated that variations in hydrography, submarine topography, and geography control seawater properties and the distribution of marine organisms, and thus determine sediment types in coastal South Florida and the Bahamas. Illing, Wells, and Taylor (1965) and Shinn, Ginsburg, and Lloyd (1965) described occurrences of evaporite and dolomite in modern tidal-flat sediments of the Persian Gulf and the Bahamas, respectively, which compared well with ancient examples of evaporites and dolomites reported by King (1948), Laporte (1967), and Fisher and Rodda (1969); thus variations in mineralogy also may be related to the carbonate depositional model. Individual versions of this carbonate depositional model are present explicitly or implicitly in the work of many current carbonate specialists, and some authors such as Irwin (1965) and Coogan (1969) have devoted entire papers to the subject.

The most common carbonate depositional model, at present, consists of a shallow-marine sedimentary prism deposited on the flanks of a hypothetical cratonic mass, continental margin, or other positive depositional or tectonic feature. Nearly all carbonate production takes place in very shallow marine water (Stockman and others, 1967; Neumann and Land, 1975), and little sediment accumulation can take place above high-tide level. In areas where sediment production exceeds subsidence rate in these shallow waters, carbonate sediments accumulate up to approximate sea level, and any additional oarbonate detritus is thereafter distributed laterally by currents, tides, and storms, eventually building a broad, very shallow submarine plain. Accordingly, the three-dimensional carbonate body-its growth limited upward by sea level and downward by subsidence-thickens away from the positive element, accreting across its subsiding flanks, toward open, deeper marine waters. At the point in this hypothetical traverse across the shelf where production and accumulation of shallow-marine carbonate sediments is exceeded by subsidence, the sediment package ceases to thicken (fig. 1) and thereafter thins progressively toward deeper water to some area where sedimentation is slow and relatively uniform in a starved basin. It is important to recognize that most starved-basin sediments have been transported from the shelf where they were manufactured. In most examples, it is at or near the shelf margin that most constructional marine communities, such as coral-algal reefs, and many coarsegrained bioclastic sediments are located (Wilson, 1974). Moreover, a constructional ridge at the shelf margin may serve to restrict ingress and egress of seawater on-

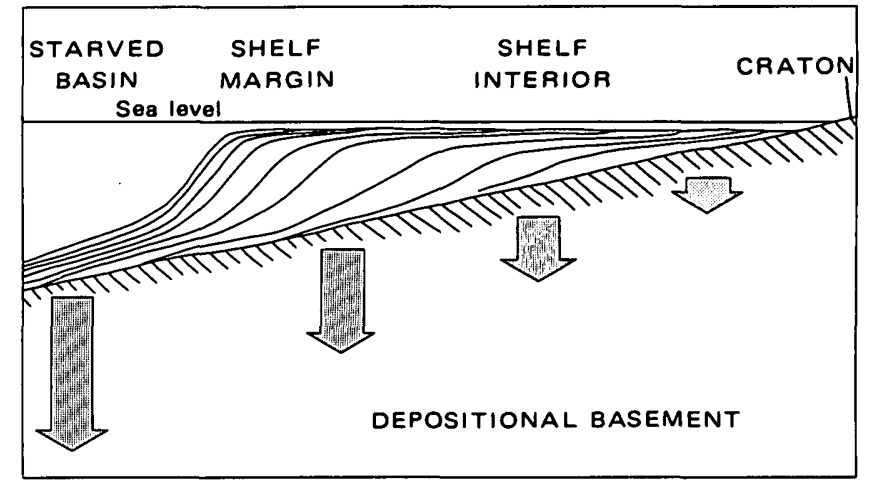

Figure 1.-Model of carbonate deposition. Lengths of arrows are proportional to rate of subsidence.

to and off the shelf, thus promoting evaporative, highly saline conditions in the shelf interior.

The end product of this carbonate depositional model is a wide, flat, very shallow depositional plain with evaporites and muddy dolomitic sediments deposited in the shelf interior and light-colored, coarser grained skeletal, calcium carbonate sediments deposited on the shelf margin. This plain terminates seaward at an abrupt break in slope where the depositional surface declines into deeper water of a starved basin in which sediment accumulation has been much slower and subisdence has been greater. Basin sediments tend to be dark and finer grained. Through time a three-dimensional prism is established, with vertical relief from the shelf edge to the basin floor commonly measured in hundreds of metres and, in at least one example (Enos, 1974 ), relief as much as $1,000 \mathrm{~m}$. Slope of the fore-reef surface may be as much as $35^{\circ}$ (Wilson, 1974) but commonly is much more gentle, perhaps $1^{\circ}-2^{\circ}$. Basinal carbonate sediments may be one-half to one-tenth as thick as their shelf equivalents.

What makes shelf margins appear so spectacular on geologic cross sections and maps is the excessive vertical exaggeration of cross sections or small contour intervals chosen for mapping, and the abrupt appearance of basinward thinning on the slope, in contrast to a regular pattern of thickening across the shelf toward the shelf margin.

\section{THE CARBONATE DEPOSITIONAL MODEL THROUGH TIME}

As long as subsidence is gradual and carbonate production and accumulation keep pace with or exceed subsidence, the shelf margin generally remains stationary or accretes seaward. But what happens if sea level drops, if subsidence ceases, or if uplift takes place on the craton? The former carbonate shelf is then flooded by terrigenous detritus derived from the craton. 
If the net sea-level change is not excessive, most of the terrigenous detritus is transported across the thenexposed carbonate terrane and dumped into the basin seaward of the old shelf margin (fig. 2). Continuation of these submergent-emergent alternations can thus produce carbonate and terrigenous successions whose geometric relationship is reciprocal (Wilson, 1967; Meissner, 1972), but whose apparent stratigraphic re- lationship is equivalent. In some examples, the transport of sand and silt across the old carbonate shelf may be so efficient that the terrigenous phase on the shelf is locally nonexistent and is frequently unrecognized.

The often substantial depositional topography involved in shelf margins, as well as the reciprocal carbonate terrigenous depositional cycles described above, makes the application of traditional stratigraphic

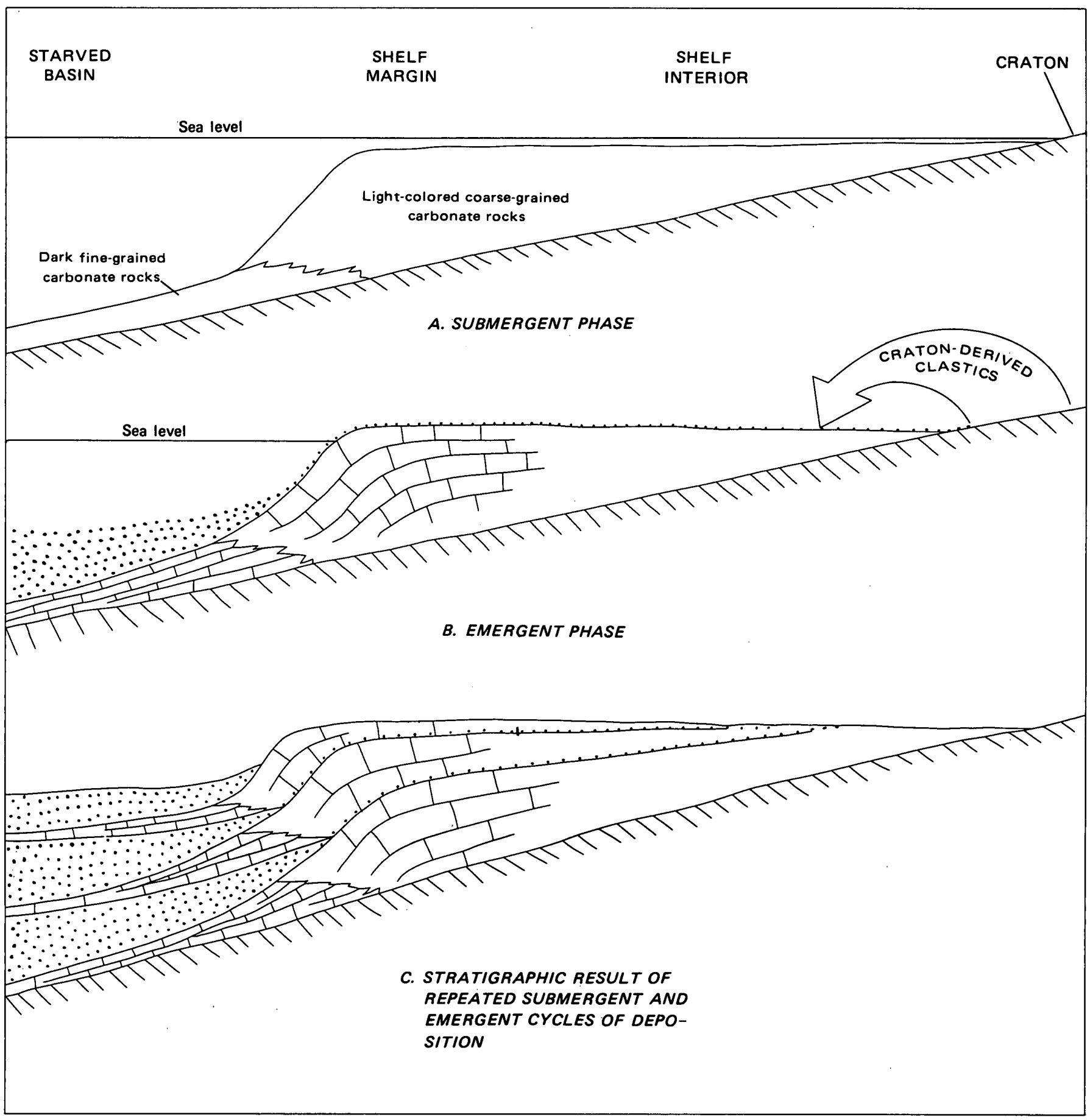

Frgure 2.-The result of cratonic uplift on the carbonate depositional model. 
methods difficult; such methods tend to be dominated by concepts of original horizontality and constant basinward thickening of sedimentary units, and have frequently been unsuccessful in dealing with carbonate sequences in the shelf-to-basin zone. As a result, many carbonate shelf margins have gone unrecognized or, at best, misunderstood. P. B. King's (1959) engrossing and sympathetic account of the difficulties experienced by early West Texas geologists trying to understand the Permian Central Basin platform illustrates the problem.

Geological literature on the Mississippian of the Western United States generally contains two kinds of misinterpretations. In some examples, shelf and shelfmargin carbonate lithosomes having reciprocal thickness relationships with immediately younger basinal lithosomes have been misinterpreted as lateral facies equivalents. (fig. $3 A$ ). In contrast, incomplete paleontological sampling has, in other examples, further confused the picture by inferring a hiatus between the thin, slowly deposited starved-basin sediments and the rapidly deposited, younger, terrigeneous, clastic basinfill sediments above; this inference has led to postulation of regional uplift and erosion (fig. $3 C$ ). These two misinterpretations can be compared with the proposed shelf-margin interpretation (fig. $3 B$ ).

\section{LOWER DEPOSITIONAL COMPLEX}

Strata in the lower depositional complex range in age from early Kinderhookian to early Meramecian. In eastern Utah and west-central Wyoming, my detailed examination of the Madison Limestone (or Group) suggests that the lower part is transgressive and open marine and that, in contrast, the upper part is regressive and contains evidence of shallower and more restricted depositional conditions increasing upward. Because the lower part of the Madison passes laterally into a shallow shelf facies, this distinction fades eastward toward the Transcontinental arch where the Madison is mapped as an undivided lithic unit. Regional eastward thinning in Colorado, New Mexico, and eastern Wyoming is in part related to late Paleozoic erosion of the top of the Leadville, Redwall, and Madison Limestones, and their equivalents. To the west and north, however, the lower transgressive and upper regressive phases (Lodgepole and Mission Canyon Limestones, respectively) become more evident in a belt that is relatively narrow northeast across central Utah and north through western Wyoming, and then widens to encompass most of Montana, including the Williston basin. Sando (1967b) called this belt the Montana province and the cratonic area to the east and the south, the Wyoming province (fig. 4). Sando called

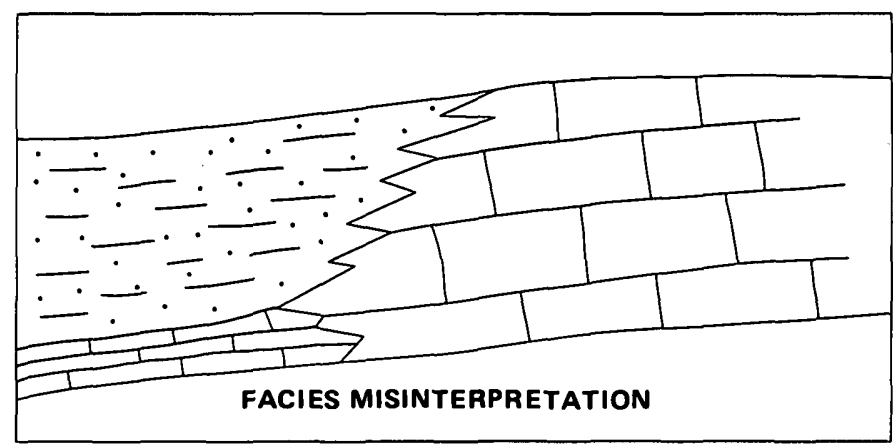

$A$

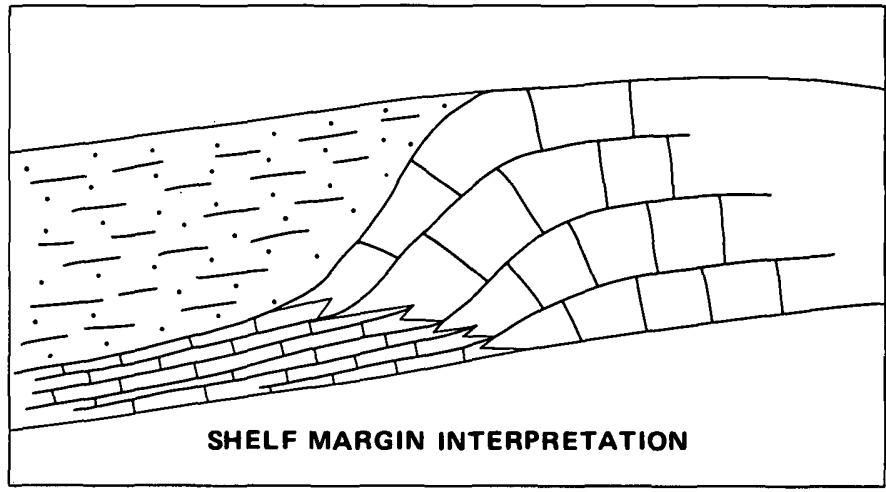

$B$

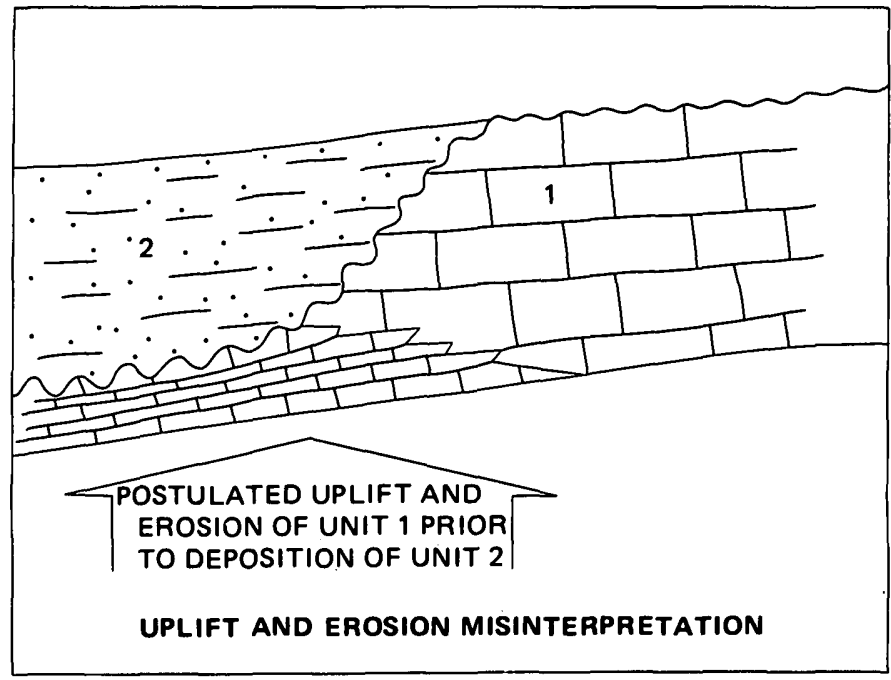

C

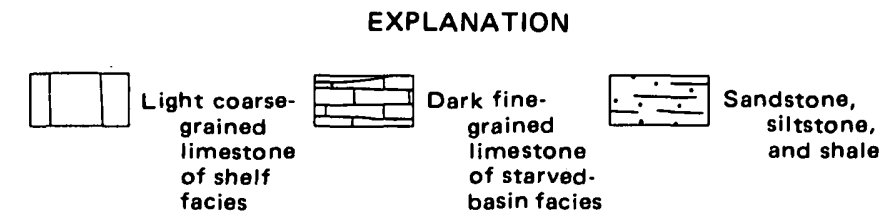

Figure 3.-Comparison of interpretations of stratigraphic relationships of lower depositional complex. A, Facies misinterpretation. $B$, Proposed interpretation of shelf margin with original depositional topography and later inflling of starved basin. $C$, Uplift and erosion misinterpretation. 


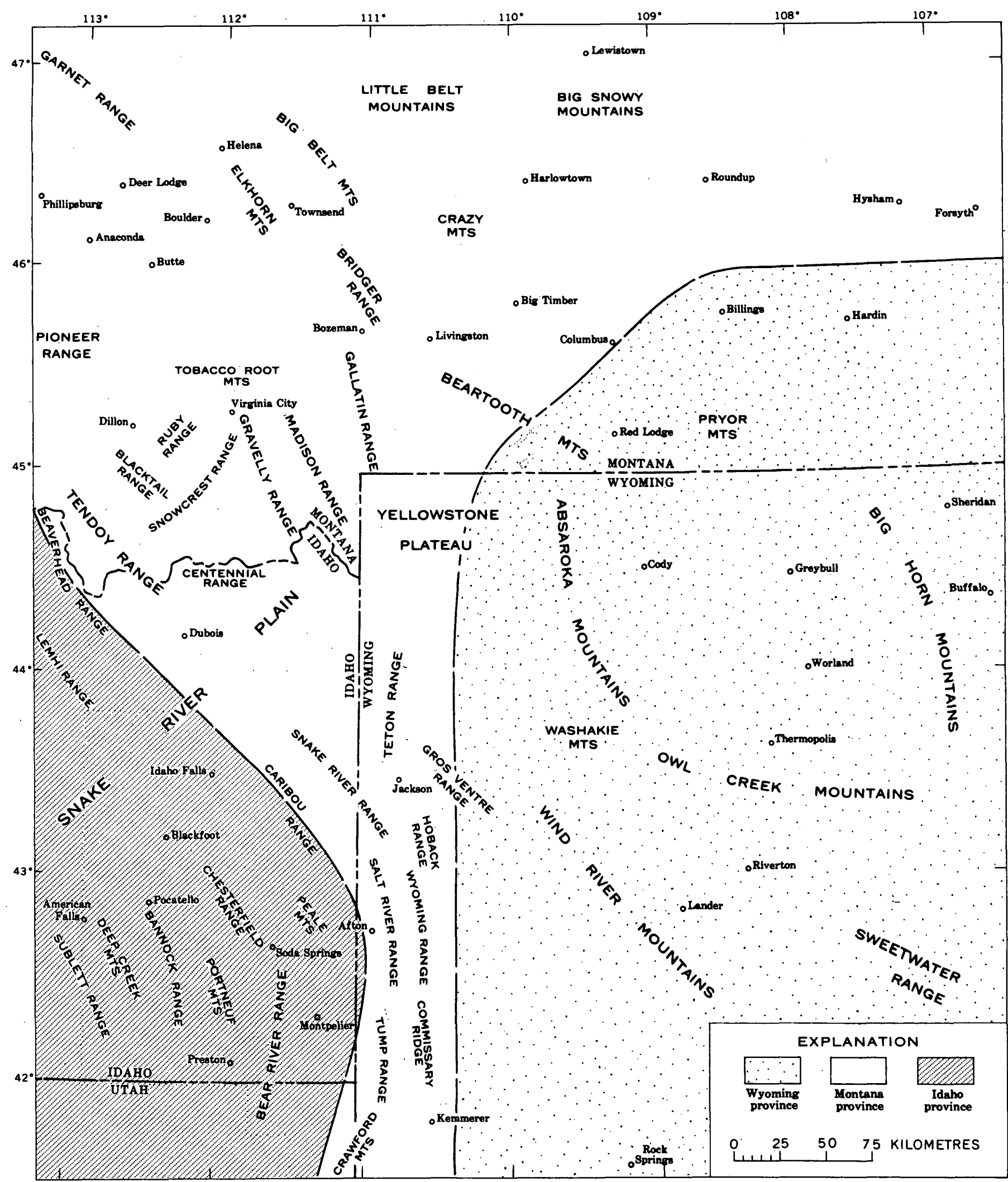

FIGURE 4.-Map of northern Cordilleran region, showing location of principal mountain ranges and Mississippian depositional provinces (modified from Sando, 1967b) 
the broad mingeosynclinal area to the west, where the upper regressive phase is absent and a thick Upper Mississippian limestone succession is present, the Idaho province. In the Montana province the lower transgressive phase is termed Lodgepole Limestone (fig. 5); in Utah it has been called upper part of the Fitchville Formation and Gardison Limestone, and in southern Nevada, Dawn and Anchor Limestone Members of the Monte Cristo Limestone (Langenheim and others, 1962). These rocks are typically dark-gray, thinbedded, cherty, fossiliferous, carbonaceous, silty limestones. The Lodgepole contains scattered bioherms. Comparison with modern carbonate sediments suggests deposition in a marine setting in water perhaps 30$100 \mathrm{~m}$ deep.

The upper regressive phase in Sando's Montana province is termed the Mission Canyon Limestone; it has been called Brazer Dolomite in northeastern Utah, Deseret Limestone in central Utah, and Bullion Dolomite and Yellowpine Limestone Members of the Monte Cristo Limestone in southern Nevada. This facies includes a diverse assemblage of light-colored, thick- to massive-bedded, relatively pure dolomites and limestones containing scattered anhydrite or gypsum, and solution breccias that represent former evaporite deposits (fig. 6). The mineralogy, textures, and sedimentary structures indicate deposition on a very shallow carbonate shelf, part of which was probably in intertidal and even supratidal settings.

In Sando's Idaho province the lower depositional complex comprises a lower Lodgepole-type, dark limestone succession (called the Joana Limestone in western
Utah and eastern Nevada) and the lower part of an overlying thin-bedded, dark calcareous siltstone or silty limestone succession (called Little Flat Formation in southeastern Idaho and northeastern Utah and the upper member of the McGowan Creek Formation (Sandberg, 1975) in east-central Idaho). Elsewhere equivalents of this dark calcareous siltstone or silty limestone succession have been called Woodman Formation in western Utah and Peers Spring Formation (as used by Langenheim, 1963) in southeastern Nevada. It should be emphasized that only the lower part of this silty succession, about $100 \mathrm{~m}$ thick, is equivalent to the upper regressive carbonate phase (= Mission Canyon). The upper part of this silty succession is genetically related to the upper depositional complex. The true Osagean age of the lower part of the Little Flat and Woodman Formations has been recently established by C. A. Sandiberg (oral commun., 1975) on the basis of conodonts collected by Sandberg and R. C. Gutschick. The age of the lower part of the Peers Spring Formation has not been demonstrated paleontologically. Although the formation has been generally regarded (Langenheim, 1963) as entirely Late Mississippian, lithologic correlation with the Woodman suggests that the age of the basal part of the Peers Spring may likewise be Osagean.

Farther west, approaching the flysch deposits derived from the Antler orogen (Poole, 1974), equivalents of the Woodman and Little Flat calcareous siltstones grade into dark silty shales of the Chainman Shale.

WEST

EAST

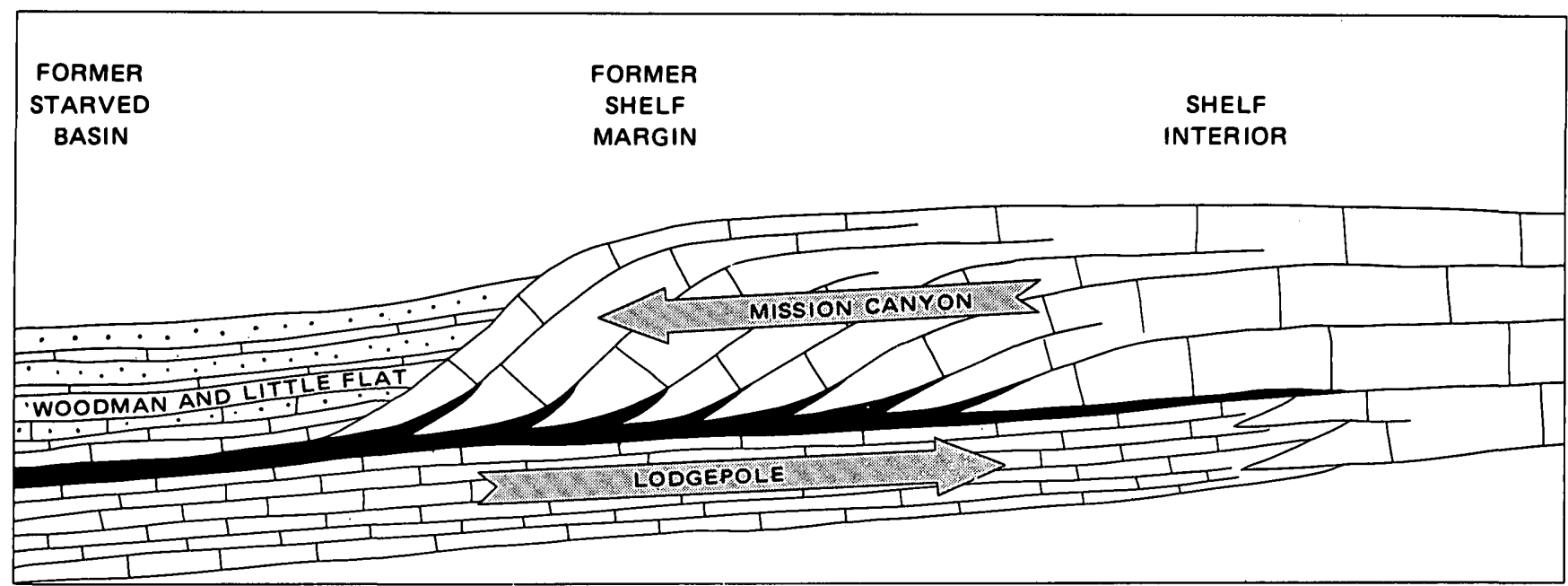

Frgure 5.-Schematic stratigraphic cross section showing the transgressive-regressive (Lodgepole and Mission Canyon Limestones) couplet of the lower depositional complex, the stratigraphic relationship of the fore-reef phosphatic zone (shown in black), and the basin-filling terrigenous clastic deposits (Woodman, Little Flat, and equivalent formations). In shelf interior Lodgepole and Mission Canyon may be undivided, as Madison Limestone. 


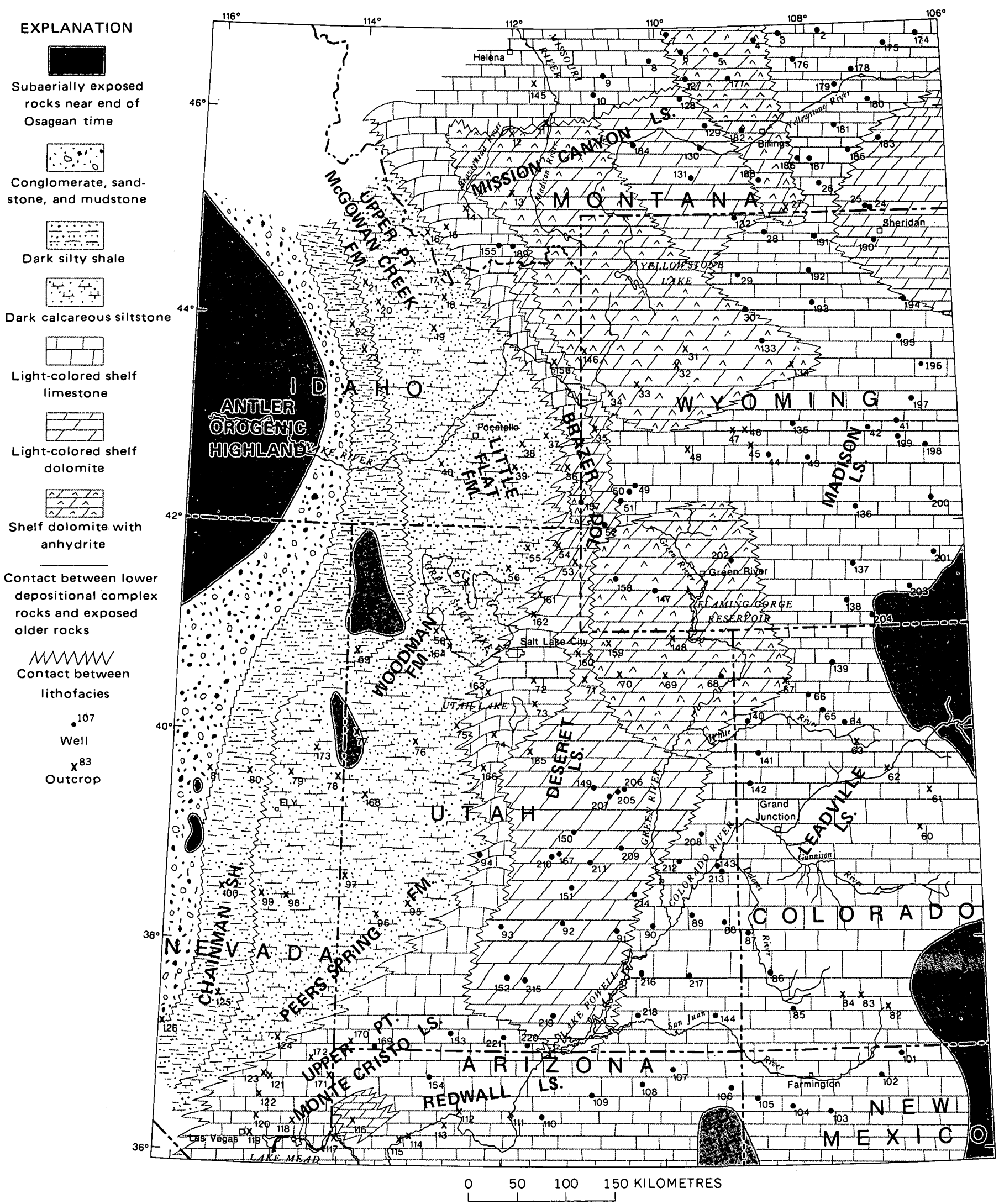

FiquRE 6.-Lithofacies map of the lower depositional complex near the end of Osagean time showing provincial formation names. 


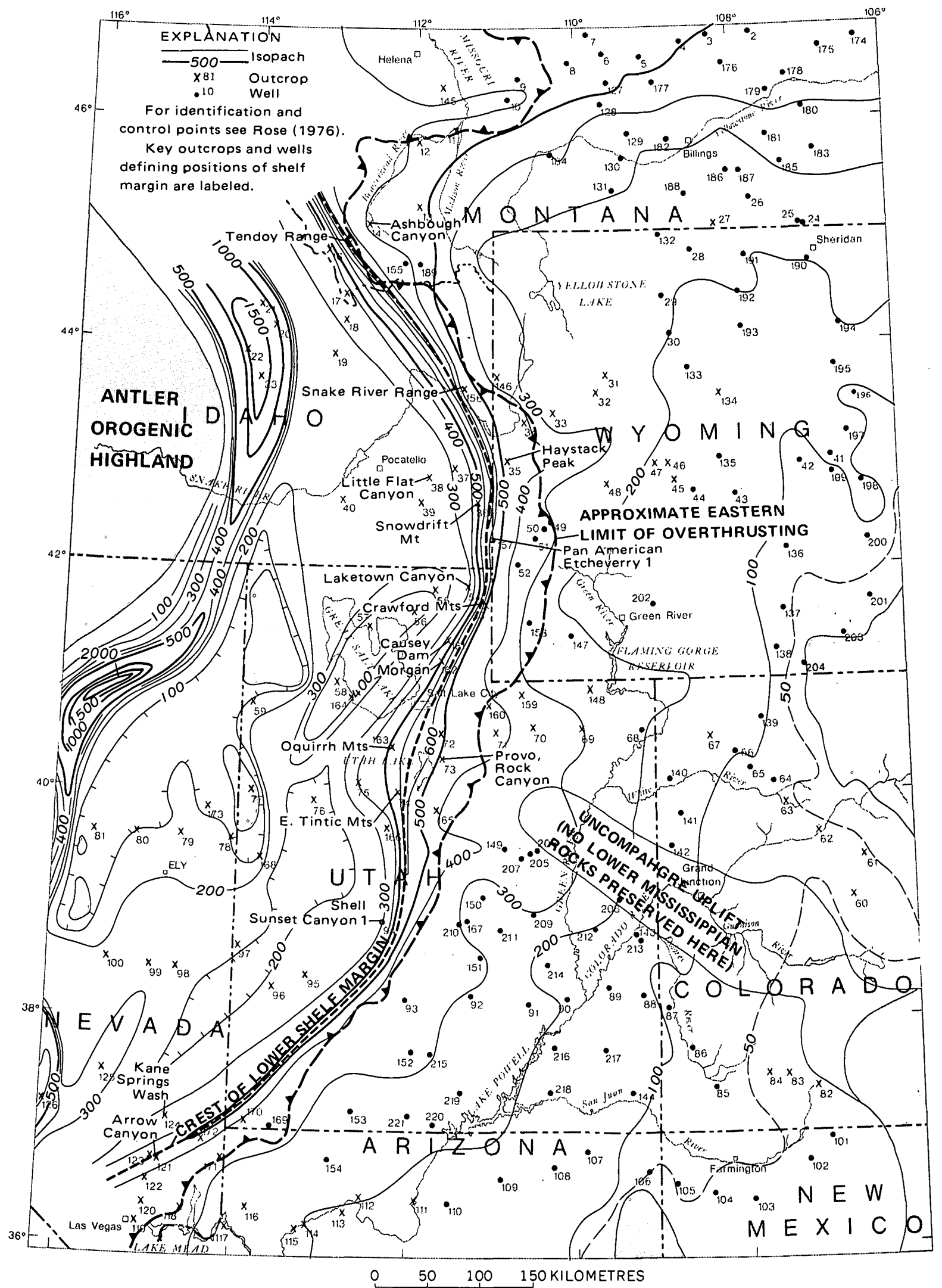

Frgure 7.-Isopach map of the lower depositional complex. Flysch trough east of Antler orogenic highland modifled from Poole (1974). Eastern edge of Antler orogenic highland in Idaho restored to compensate for easttern overthrusting. Patterned areas indicate nondeposition or erosion of lower depositional complex. Hach. ures on isopachs point to areas of thinning. Isopach interval 50 (dashed), 100 , and $500 \mathrm{~m}$. 
Of particular significance are the areal distribution and stratigraphic position of a thin phosphatic zone with respect to the transgressive-regressive lower carbonate couplet (Lodgepole and Mission Canyon) and to the siltstones (Little Flat and Woodman) that fill the formerly starved basin (fig. 5). The phosphatic zone is best developed either in the area of the lower shelf margin, where it occurs invariably at the boundary between the deeper water transgressive facies and the overlying regressive shelf facies, or in the starved basin west of the shelf margin, where it occurs at the base of the silty Woodman and Little Flat (Gutschick, 1976, fig. 4b; Sando and others, 1976). If one assumes that this phosphatic zone represents very slow accumulation in an upwelling marine setting, its maximum development would be expected at the toe of the westward-accreting Mission Canyon stratigraphic reef, in the starved basin where sedimentation is known to have been slow. C. A. Sandberg and R. C. Gutschick are currently pursuing the details of this economically significant stratigraphic unit.

\section{EVIDENCE FOR LOWER SHELF MARGIN}

Five lines of evidence support the existence of a prominent, accretionary, constructional carbonate shelf margin, or stratigraphic reef (Dunham, 1970) having substantial seaward topographic relief that developed during the latter phases of deposition of the lower carbonate complex :

1. Isopach mapping (fig. 7) indicates a curvilinear, presumably constructional, ridge trending northeast across Utah from southern Nevada, then curving north and northwest across eastern Idaho, and finally crossing into westernmost Montana.

2. The widespread occurrence of dolomites and evaporites in the shelf regions of central Utah and Wyoming suggests the presence of a physical barrier that restricted circulation of normal marine water's onto the shelf.

3. Abrupt basinward thinning occurs directly west of the curvilinear carbonate ridge. This thinning is gentlest and least apparent in southwestern Utah and southern Nevada, where the lower depositional complex is about $500 \mathrm{~m}$ thick along the crest of the linear ridge and a little less than $250 \mathrm{~m}$ thick about $30 \mathrm{~km}$ basinward to the northwest. In central Utah, the lower depositional complex thins from nearly $600 \mathrm{~m}$ to $200 \mathrm{~m}$ in a distance of less than $20 \mathrm{~km}$. The basinward thinning is most pronounced along the Idaho-Montana border, where the isopached unit thins basinward from about $800 \mathrm{~m}$ to about $400 \mathrm{~m}$ in a distance of only $20 \mathrm{~km}$.
This pronounced thinning suggests topographic relief along the foreslope of perhaps $200-400 \mathrm{~m}$, assuming that no compensatory isostatic adjustment occurred for the thicker shelf margin sediment load during Meramecian time and that correlation surfaces are in fact isochronous. Further, if the carbonate ridge crest was essentially at sea level, as the shallow-water carbonates suggest, water depth in the starved basin to the west was about $200-400 \mathrm{~m}$.

4. A profound change in facies coincides with the basinward thinning (fig. 6). Schematic regional cross sections (fig. 8) show that shelf carbonates of the upper regressive phase (Mission Canyon and equivalents) thin abruptly and disappear, apparently grading into much thinner, dark silty carbonates of the lower part of the Woodman, the Little Flat, and their equivalents. These silty sediments represent craton-derived terrigenous clastics swept across the shelf during periods of exposure and gentle cratonic uplift. (See section "The Carbonate Depositional Model Through Time.") They are genetically related to the sandy carbonates of the Humbug Formation of eastern and central Utah; these carbonates accumulated in an east-west trough that seems to have served as a broad conduit for transport of terrigenous clastics from the shelf into the starved basin primarily after the close of Mission Canyon deposition, when the carbonate shelf was subaerially exposed. The transgressive Lodgepole (and equivalent) carbonates seem relatively unaffected by any thickness or lithologic changes, in contrast to the shelf-to-basin changes of the Mission Canyon and Little Flat. The previous characterization of the Mission Canyon as regressive is compatible with the earlier discussion of the accretionary process of shelf-margin construction. (See section "The Carbonate Depositional Model Through Time.") Although he was the first to recognize this combination of facies change and basinward thinning, Sando $(1967 \mathrm{~b}, 1975,1976)$ ascribed the relationship to Meramecian uplift and erosion, which removed all the Mission Canyon strata in the Idaho Province and which was followed by subsidence that accommodated Little Flat deposits (fig. $3 C$ ). However, Sando's original interpretation is modified in a companion paper (Sando and others, 1976) to coincide essentially with the concept presented herein.

5. The consistency of these thickness and facies changes along a regional curvilinear trend is similar to that of other well-documented shelf 
margins, such as the Lower Cretaceous Edwards reef trend of the Gulf Coast region and the Guadalupian shelf margin in the Permian Basin of West Texas and New Mexico.

In summary, the lower depositional complex represents a complete miogeosynclinal sequence with a wide cratonic carbonate shelf thickening gradually to the west. This carbonate shelf was terminated on the west by an accretional barrier-type shelf margin having seaward topographic relief of several hundred metres. Behind this stratigraphic reef accumulated shelfinterior evaporites and low-energy, very shallow water dolomites and limestones. Seaward of this shelf margin, deposition occurred slowly in a starved basin, where dark silty limestones and shales formed in waters as much as $400 \mathrm{~m}$ deep. Madison-equivalent basinal sediments thin westward toward the thick Lower Mississippian flysch deposits derived from the Antler orogenic belt (Poole, 1974). The lower depositional complex can therefore be characterized as a transgressiveregressive carbonate couplet; shelf-interior evaporites, constructional skeletal shelf-margin carbonates, and dark starved-basin sediments were generated during the upper regressive phase.

If this postulated shelf margin is so prominent, why was it not recognized long ago, inasmuch as the Madison and its equivalents have been studied so widely and for so many years? There are probably two reasons:

1. Most of the mountain ranges in which the shelf margin occurs are controlled by Laramide thrust faults, which trend generally north-south. Thus these mountain ranges tend to be narrow features also elongated north-south. Unfortunately, the shelf margin is also a linear north-south feature. Accordingly, the presence of extended east-west outcrops is severely limited, and the possibility of viewing the outcropping shelf margin in an extended depositional dip direction, which would trend east-west, is extremely rare. On the other hand, the presence of spectacular, clear outcrops of the Guadalupian shelf margin, oriented parallel to depositional dip and showing steep accretionary reef foreset beds, was of great help in identifying and understanding the Permian Reef of West Texas.

2. Carbonate stratigraphy has undergone a revolution in the past 20 years. Many previous workers were simply unfamiliar with carbonate-style stratigraphy. Traditional stratigraphic concepts and methods, particularly when applied to submarine depositional topography, simply did not lead themselves readily to working out the true nature of carbonate-shelf and starved-basin relationships.

\section{UPPER DEPOSITIONAL COMPLEX}

The upper depositional complex contains strata of middle Meramecian through middle late Chesterian age. It specifically excludes the thick lens of Manning Canyon Shale of latest Chesterian and Morrowan age that filled the foundering incipient Oquirrh basin of central Utah; it also excludes thinner contemporaneous black shales of the so-called Chainman Shale that overlie Great Blue shelf carbonates in western and northern Utah.

The upper depositional complex reflects sedimentation in a relatively narrow, rapidly subsiding miogeosyncline confined between an emergent craton on the east and the active Antler orogen on the west.

Thin deposits of red beds and sandstones form an apron along the emergent craton to the east (fig. 9); these are the basal deposits of the Amsden Formation. Two east-west depressions indent this upper shelf. The northernmost is the Big Snowy trough of central Montana, filled by estuarine sands, silty limestones, and black carbonaceous shales of the Big Snowy Group. To the south, in northeastern Utah and northwestern Colorado, is the counterpart of the Big Snowy trough, here called the Doughnut trough (Uinta basin of Sando and others, 1975). This east-west depression, precursor to the Pennsylvanian Oquirrh basin, began to form near the end of Deseret deposition. During deposition of the upper carbonate complex, this depression was first the conduit for transport of cratonic sands of the Humbug Formation into the starved basin west of the old lower shelf margin (p. 458), and it later received thick deposits of euxinic black shales and limestones of the Doughnut and Great Blue Formations. Regional mapping shows clearly, however, that the Doughnut trough was a cratonic depression behind the upper shelf margin, separated from the Late Mississippian Cordilleran seaway by a wide belt of thick shallowmarine shelf limestones of the Great Blue and Ochre Mountain Limestones.

Scattered islands or ridges of Madison-age carbonate rocks projected above the depositional surface of the upper shelf interior and were never covered. Prominent among these was a north-south ridge along the Wyoming-Idaho border, representing the exposed crest of the lower shelf margin. This feature was called the Bannock Highland by Richardson (1941). The highest observed average porosity of outcropping Madison-age carbonate rocks in the entire study area is present here, possibly owing to Late Mississippian subaerial exposure and leaching. 


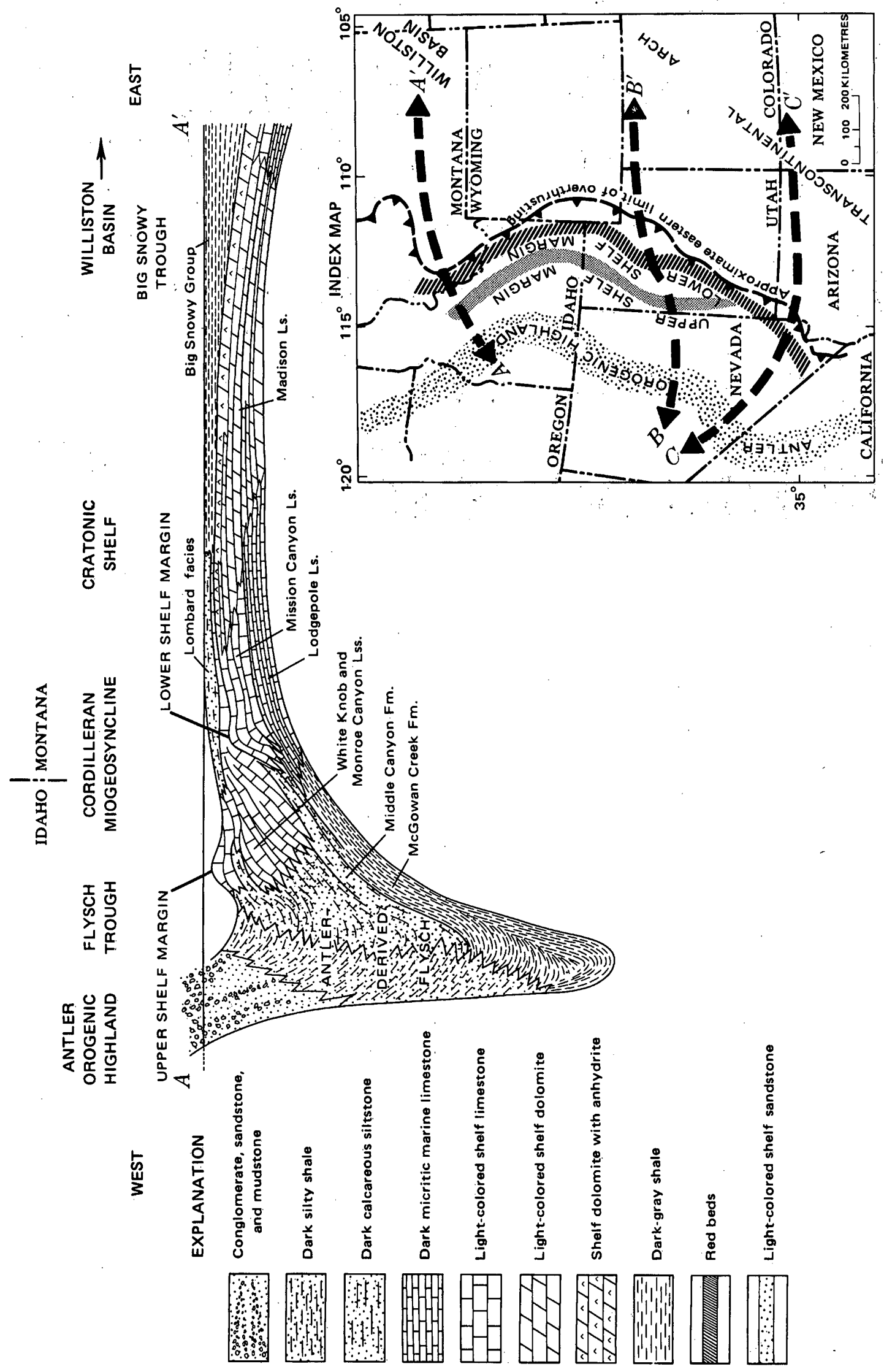




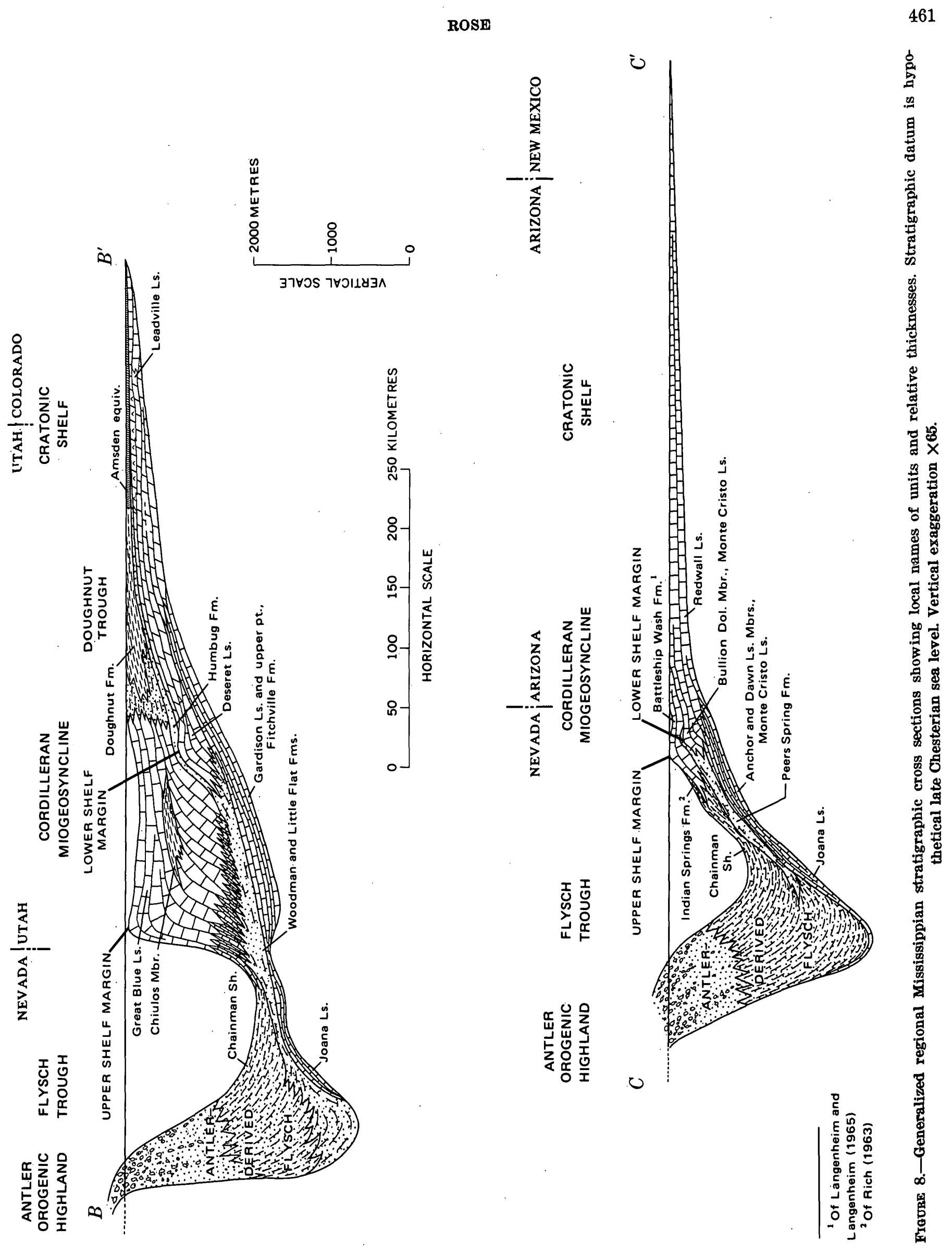




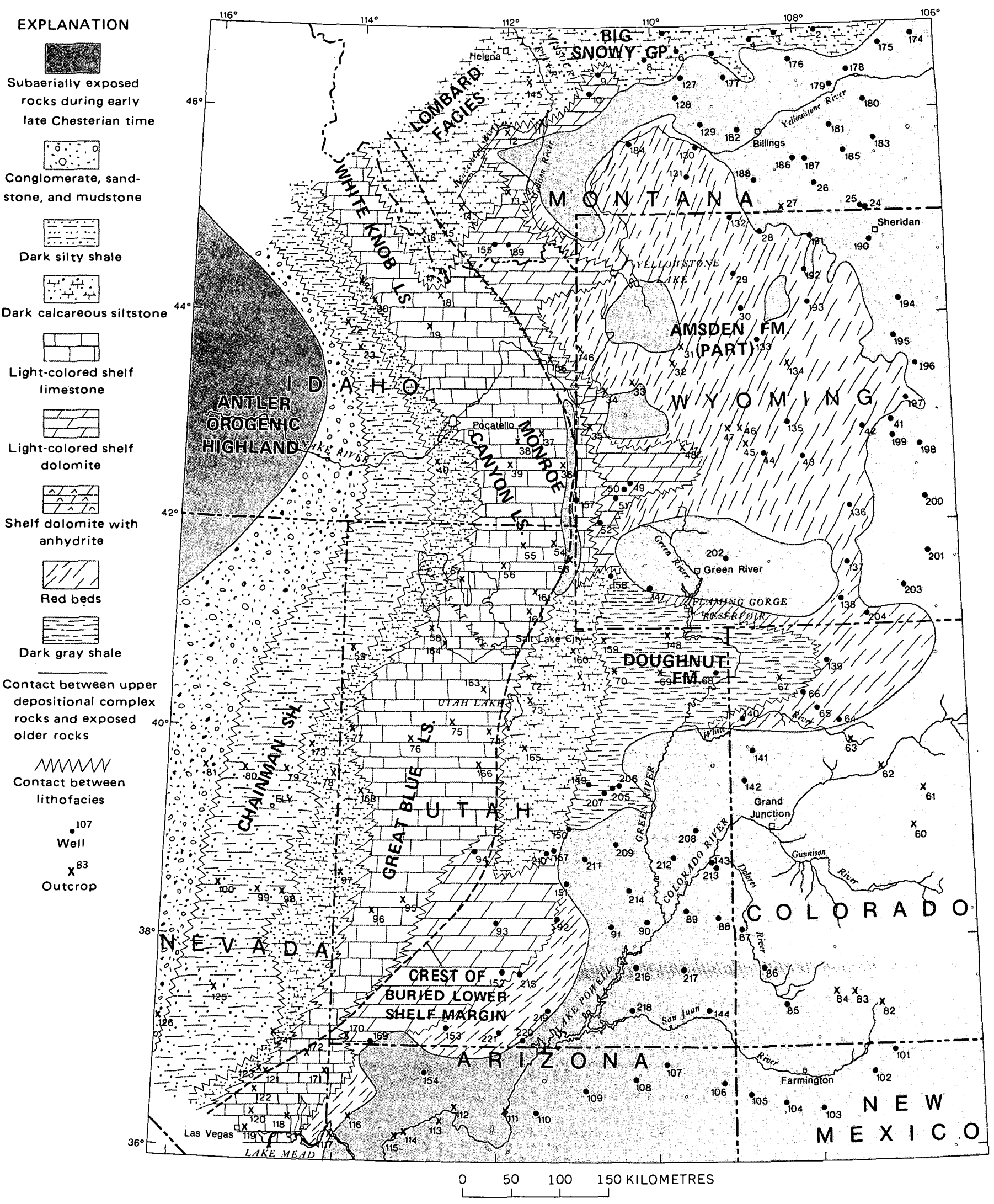

Froure 9.-Lithofacies map of the upper depositional complex in early late Chesterian time showing provincial formation names. 


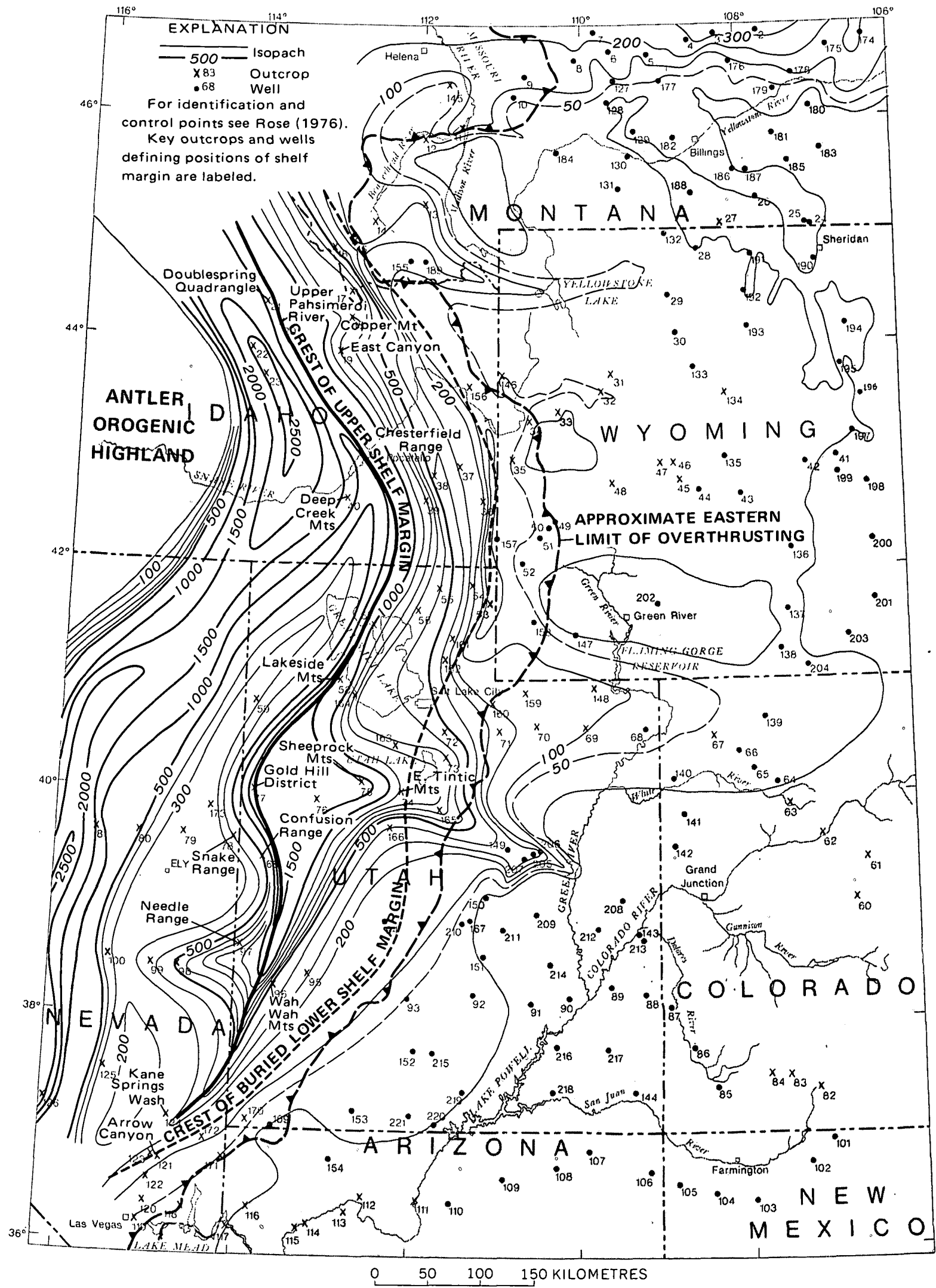

Figure 10.-Isopach map of the upper depositional complex. Flysch trough east of Antler orogenic highland modifled from Poole (1974). Eastern edge of Antler orogenic highland in Idaho restored to compensate for eastern overthrusting. Patterned areas indicate nondeposition or erosion of upper depositional complex. Hachures on isopachs point to areas of thinning. Isopach interval 50 (dashed), 100, and $500 \mathrm{~m}$. 
As the upper depositional complex thickens westward across the shelf, the eastern red beds grade into sandy dolomites that in turn grade into thick-bedded, skeletal shelf limestones, which reach a maximum thickness of at least $1,500 \mathrm{~m}$ in west-central Utah and more than $1,000 \mathrm{~m}$ in northeastern Idaho (fig. 10). This thick carbonate succession has been oalled the White Knob Limestone and Scott Peak, South Creek, and Surrett Canyon Formations in east-central Idaho, Monroe Canyon Limestone or upper part of the so-called Brazer Limestone in southeastern Idaho, Ochre Mountain Limestone in westernmost Utah, Great Blue Limestone throughout most of central Utah, and, where it is much thinner in southern Nevada, the Battleship Wash Formation of Langenheim and Langenheim (1965).

The conspicuous transgressive-regressive character of the lower carbonate depasitional complex is somewhat less apparent in the upper carbonate depositional complex. Instead, a basal terrigenous clastic succession, the upper parts of the silty Woodman, Peers Spring, Little Flat, and Middle Canyon Formations previously described, is ubiquitous beneath the upper carbonate succession. I believe most of this terrigenous clastic sequence represents a cratonic sand sheet swept across the exposed and eroding lower shelf and dropped into the basin after the close of Madison deposition. Much of the middle or upper silty facies, therefore, is correlative with the unconformity at the top of the Madison and has no recognized shelf equivalents, except for the Humbug Formation, the Darwin Member of the Amsden Formation, and sandstone fillings of post-Madison karst topography. The thick upper depositional succession appears to consist of several thick carbonate cycles, rather than the simple transgressive-regressive couplet of its lower counterpart. Huh (1967), however, emphasized the overall accretionary offlap nature of the entire upper carbonate succession (White Knob Limestone) in northeastern Idaho.

Farther west, the carbonate rocks of the upper depositional complex grade into thin, dark, silty limestones and calcareous siltstones, just as the lower shelf carbonate rocks grade into comparable dark, basinal, silty carbonate deposits. These Upper Mississippian basinal deposits are included in the upper part of the Woodman, Peers Spring, and Chainman Formations in Utah and Nevada and in part of the Deep Creek Formation of eastern Idaho. These sediments in turn grade westward into flysch deposits of the Antler foreland basin, which were derived from the Antler orogenic highland.

In western Utah and eastern Nevada, the Upper Mississippian basinal silty carbonates occur in a starved-basin setting, where they are generally 300-500 $m$ thick; equivalent shelf carbonate rocks to the east are three or four times thicker (fig. 8, cross-section $\left.B-B^{\prime}\right)$. Northward in Idaho, however, the depositional trough narrows markedly, the Antler-derived flysch deposits are adjacent to shelf limestone deposits, and no starved basin is present (fig. 8 , cross-section $A-A^{\prime}$ ).

South of the thick carbonate accumulation in westcentral Utah, the Great Blue Limestone apparently thins gradually, converges upon, and finally pinches out against the old lower shelf margin in southern Nevada (fig. 8, cross-section $C-C^{\prime}$ ). Here the thin Battleship Wash Formation appears to be equivalent to all the thicker Great Blue carbonate rocks to the north.

\section{EVIDENCE FOR UPPER SHELF MARGIN}

Available evidence suggests that the upper shelf margin may have been more complex than its lower counterpart. Nevertheless, the same five main elements of evidence exist:

1. Isopach mapping (fig. 10) suggests the existence of a constructional barrier that could have restricted circulation of marine waters in the shelf interior.

2. The presence of dolomites and red beds indicates restricted circulation in the shelf interior.

3. Isopach mapping shows abrupt basinward thinning in Utah immediately seaward of the barrier, suggesting topographic relief of $500-1,000 \mathrm{~m}$. Proximity of Antler flysch deposits to the shelf margin in central Idaho apparently precluded formation of a deep starved basin there, however, and so distal orogenic and carbonate deposits are intertongued along the shelf margin.

4. Massive skeletal limestone beds change facies to dark silty carbonates coincident with the aforementioned basinward thinning (fig. 9).

5. All these features occur in a consistent regional pattern analogous to other ancient and modern shelf margins, and also similar to the immediately underlying lower shelf margin.

In summary, the upper depositional complex represents carbonate shelf sedimentation in a miogeosynclinal setting between an emergent craton on the east, which shed terrigenous clastics into the shelf interior, and an active orogen on the west, with its accompanying flysch trough. This north-south carbonate shelf was crossed by two elongate east-west troughs filled with cratonic sands and euxinic muds. Substantial topographic relief of perhaps as much as 1,000 m developed where the carbonate shelf margin declined into the starved basin. In Idaho, however, where the flysch trough converges upon the carbonate shelf, probably 
little topographic relief developed at the edge of the upper carbonate shelf.

\section{PERTINENT FUTURE RESEARCH}

Three lines of future research on Mississippian shelf margins of the Western United States are suggested:

1. Detailed field investigations in appropriately located mountain ranges are needed for both the lower and upper shelf-carbonate successions, to determine if shelf-margin features can be recognized in outcrop and to compare such features with other ancient counterparts, as well as with features in different parts of the same Mississippian shelf. Such investigations may document the nature of the lower and upper shelf margins and add new dimensions to existing shelf-margin concepts. Preliminary investigations in some parts of the report area have already been initiated by F. G. Poole, C. A. Sandberg, and myself. Continuing detailed biostratigraphic studies by W. J. Sando, J. T. Dutro, Jr., Mackenzie Gordon, Jr., and B. L. Mamet in Wyoming, Montana, Idaho, and Utah will also provide important data.

2. Using the shelf-margin concept, eastern Great Basin stratigraphy should be reevaluated, specifically in regard to possible petroleum source rocks and phosphate-rich units, as well as preferentially mineralized rock units or facies. Such a study is underway by Gutschick (1976) and Sandberg (1975).

3. The distribution of porosity and permeability in the lower carbonate depositional complex should be examined in light of the shelf-margin model to see if useful generalizations can be made regarding primary carbonate facies, early diagenetic history, and development and present occurrence of reservoir rocks and seals.

\section{REFERENCES CITED}

Adams, J. E., Frenzel, H. N., Rhodes, M. I., and Johnson, D. P., 1951, Starved Pennsylvanian Midland basin: Am. Assoc. Petroleum Geologists Bull., v. 35, no. 12, p. 26002607.

Andrichuk, J. M., 1955, Mississippian Madison group stratigraphy and sedimentation in Wyoming and southern Montana: Am. Assoc. Petroleum Geologists Bull., v. 39, no. 11 , p. 2170-2210.

Coogan, A. H., 1969. Recent and ancient carbonate cyclic sequence, in Cyclic sedimentation in the Permian BasinSymposium, Midland, Texas, 1967: West Texas Geol. Soc. Pub. 69-56, p. 5-16.

Craig, L. C., 1972, Mississippian System, in Mallory, W. W., ed., Geologic atlas of the Rocky Mountain region: Rocky Mtn. Assoc. Geologists, p. 100-110.
Dunham, R. J., 1970, Stratigraphic reefs versus ecologic reefs : Am. Assoc. Petroleum Geologists Bull., v. 54, no. 10, p. 1931-1932.

Eardley, A. J., 1962, Structural geology of North America [2d ed.] : New York, Harper and Row, 743 p.

Enos, Paul, 1974, Reefs, platforms and basins of Middle Cretaceous in northeast Mexico: Am. Assoc. Petroleum Geologists Bull., v. 58, no. 5, p. 800-809.

Fisher, W. L., and Rodda, P. U., 1969, Edwards Formation (Lower Cretaceous), Texas-Dolomitization in a carbonate platform system: Am. Assoc. Petroleum Geologists Bull., v. 53, no. 1, p. 55-72.

Ginsburg, R. N., 1956, Environmental relationships of grain size and constituent particles in some south Florida carbonate sediments: Am. Assoc. Petroleum Geologists Bull., v. 40 , no. 10 , p. $2384-2427$.

Gutschick, R. C., 1976, Preliminary reconnaissance study of Lower and lower Upper Mississippian strata across northwestern Utah: U.S. Geol. Survey Open-Fle Report 76200, $40 \mathrm{p}$.

Hintze, L. F., 1973, Geologic history of Utah : Brigham Young Univ. Geology Studies, v. 20, pt. 3, 191 p.

Huh, O. K., 1967, The Mississippian System across the Wasatch line, east-central Idaho, extreme southwestern Montana, in Montana Geol. Soc. Guidebook 18th Ann. Field Conf., 1967, Centennial basin of southwest Montana: p. 31-62.

Illing, L. V., Wells, A. J., and Taylor, J. C. M., 1965, Penecontemporary dolomite in the Persian Gulf, in Pras, $\mathrm{L}$. C., and Murray, R. C., eds., Dolomitization and limestone diagenesis-a symposium: Soc. Econ. Paleontologists and Mineralogists Spec. Pub. 13, p. 89-111.

Imbrie, John, and Purdy, E. G., 1962, Classification of modern Bahamian carbonate sediments, in Classification of carbonate rocks-A symposium: Am. Assoc. Petroleum Geologists Mem. 1, p. 253-272.

Irwin, M. L., 1965, General theory of epeiric clear water sedimentation: Am. Assoc. Petroleum Geologists Bull., v. 49, no. 4 , p. $445-459$.

Jackson, W. E., 1964, Depositional topography and cyclic deposition in west-central Texas: Am. Assoc. Petroleum Geologists Bull., v. 48, no. 3, p. 317-328.

Kay, Marshall, 1951, North American geosynclines: Geol. Soc. America Mem. 48, 143 p.

King, P. B., 1948, Geology of the southern Guadalupe Mountains, Texas: U.S. Geol. Survey Prof. Paper 215, 183 p. [1949].

- 1959, The evolution of North America: Princeton, N. J., Princeton Univ. Press, 190 p.

Langenheim, R. L., Jr., 1963, Nomenclature of the late Mississippian White Pine Shale and associated rocks in Nevada: Illinois Acad. Sci. Trans. 1962, v. 55, no. 2, p. 133-145.

Langenheim, R. L., Jr., Carss, B. W., Kennerly, J. B. McCutcheon, V. A., and Waines, R. H., 1962, Paleozoic section in Arrow Canyon Range, Clark County, Nevada: Am. Assoc. Petroleum Geologists Burl., v. 46, no. 5, p. 592-609.

Langenheim, V. A. M., and Langenheim, R. L., Jr., 1965, The Bird Spring Group, Chesterian through Wolfcampian at Arrow Canyon, Arrow Canyon Range, Clark County, Nevada: Illinois Acad. Sci. Trans., v. 58, no. 4, p. 225240. 
Laporte, L. F., 1967, Carbonate deposition near mean sealevel and resultant facies mosaic-Manlius Formation (Lower Devonian) of New York State: Am. Assoc. Petroleum Geologists Bull., v. 51, no. 1, p. 73-101.

Meissner, F. F., 1972, Cyclic sedimentation in Middle Permian strata of the Permian Basin, west Texas and New Mexico, in Cyclic sedimentation in the Permian Basin-Symposium, Midland Texas, 1967 [2d ed.]: West Texas Geol. Soc. Pub. 72-60, p. 203-232.

Neumann, A. C., and Land, L. S., 1975, Lime mud deposition and calcareous algae in the Bight of Abaco, BahamasA budget: Jour. Sed. Petrology, v. 45, no. 4, p. 763-786.

Poole, F. G., 1974, Flysch deposits of Antler foreland basin, western United States, in Dickinson, W. R., ed., Tectonics and sedimentation: Soc. Econ. Paleontologists and Mineralogists Spec. Pub. 22, p. 58-82.

Rich, J. L., 1951, Three critical environments of deposition, and criteria for recognition of rocks deposited in each of them: Geol. Soc. America Bull., v. 62, no. 1, p. 1-20.

Rich, Mark, 1963, Petrographic analysis of Bird Spring Group (Carboniferous-Permian) near Lee Canyon, Clark County, Nevada: Am. Assoc. Petroleum Geologists Bull., v. 47 , no. 9 , p. $1657-1661$.

Richardson, G. B., 1941, Geology and mineral resources of the Randolph quadrangle, Utah-Wyoming: U.S. Geol. Survey Bull. 923, $54 \mathrm{p}$.

Rose, P. R., 1976, Key wells and outcrops for regional analysis of Mississippian rocks, Western United States: U.S. Geol. Survey Open-Fle Report 76-242.

Sandberg, C. A., 1975, McGowan Creek Formation, new name for Lower Mississippian flysch sequence in east-central Idaho: U.S. Geol. Survey Bull. 1405-E, 11 p.

Sando, W. J., 1967a. Madison Limestone (Mississippian), Wind River, Washakie, and Owl Creek Mountains, Wyoming: Am. Assoc. Petroleum Geologists Bull., v. 51, no. 4, p. 529-557.

1967b, Mississippian depositional provinces in the northern Cordilleran region, in Geological Survey research 1967 : U.S. Geol. Survey Prof. Paper 575-D, p. D29-D38.

1972, Madison Group (Mississippian) and Amsden Formation (Mississippian and Pennsylvanian) in the Beartooth Mountains, northern Wyoming and southern Montana, in Montana Geol. Soc. Guidebook, 21st Ann. Field Conf., Crazy Mountains Basin, 1972: p. 57-63, 1, p., 9 figs.
1974, Mississippian history of the northern Rocky Mountains (abs.) : Geol. Soc. America Abs. with Programs, v. 6, no. 7, p. 938-939.

1975, Diastem factor in Mississippian rocks of the northern Rocky Mountains: Geology, v. 3, no. 11, p. 657660.

1976, Mississippian history of the northern Rocky Mountain region: U.S. Geol. Survey Jour. Research, v. 4, no. 3, 317-338.

Sando, W. J., and Dutro, J. T., Jr., 1960, Stratigraphy and coral zonation of the Madison group and Brazer dolomite in northeastern Utah, western Wyoming, and southwestern Montana, in Wyoming Geol. Assoc. Guidebook 15th Ann. Field Conf., Overthrust belt of southwestern Wyoming and adjacent areas 1960 : p. 117-126.

Sando, W. J., Dutro, J. T., Jr., Sandberg, C. A., and Mamet, B. L., 1976, Revision of Mississippian stratigraphy, eastern Idaho and northeastern Utah: U.S. Geol. Survey Jour. Research, v. 4, no. 4, p. 467-479.

Sando, W. J., Gordon, Mackenzie, Jr., and Dutro, J. T., Jr., 1975, Stratigraphy and geologic history of the Amsden Formation (Mississippian and Pennsylvanian) of Wyoming: U.S. Geol. Survey Prof. Paper 848-A, 78 p., 11 pls., 23 figs.

Shinn, E. A., Ginsburg, R. N., and Lloyd, R. M., 1965, Recent supratidal dolomite from Andros Island, Bahamas, in Pray, L. C., and Murray, R. C., eds., Dolomitization and limestone diagenesis-A symposium: Soc. Econ. Paleontologists and Mineralogists Spec. Pub. 13, p. 112-123.

Stockman, K. W., Ginsburg, R. N., and Shinn, E. A., 1967, The production of lime mud by algae in south Florida: Jour. Sed. Petrology, v. 37, no. 2, p. 633-648.

Van Siclen, D. C., 1958, Depositional topography-Examples and theory; Am. Asoc. Petroleum Geologists Bull., v. 42, no. 8, p. 1897-1913.

Wilson, J. L., 1967, Cyclic and reciprocal sedimentation in Virgilian strata of southern New Mexico: Geol. Soc. America Bull., v. 78, no. 7, p. 805-818.

1974, Characteristics of carbonate-platform margins: Am. Assoc. Petroleum Geologists Bull., v. 58, no. 5, p. 810-824. 


\title{
REVISION OF MISSISSIPPIAN STRATIGRAPHY, EASTERN IDAHO AND NORTHEASTERN UTAH
}

\author{
By WILLIAM J. SANDO, J. THOMAS DUTRO, Jr.; \\ CHARLES A. SANDBERG, and BERNARD L. MAMET, ${ }^{1}$ \\ Washington, D.C.; Denver, Colo., Montréal, Canada
}

\begin{abstract}
New paleontologic evidence requires a revision of previous interpretations of the stratigraphy of Mississippian sequences in the Cordilleran miogeosyncline of eastern Idaho and northeastern Utah. A postulated unconformity between rocks of early Osagean age and rocks of middle Meramecian age is no longer tenable in the light of new data. The new evidence supports continuous deposition from the Lodgepole Limestone (Kinderhookian and early Osagean age) into the Little Flat Formation (early Osagean to middle Meramecian age) and its equivalents, and the interpretation of a phosphatic siltstone and shale interval in the lower part of the Little Flat Formation as a starved-basin facies.
\end{abstract}

Recent interpretations of Mississippian stratigraphy in eastern Idaho and northeastern Utah (Dutro and Sando, 1963; Sando, 1967b, 1975, 1976; Sando and others, 1969, 1975; Sando and Mamet, 1974) have postulated a major regional unconformity between rocks of early Osagean age and rocks of middle Meramecian age. Evidence for this interpretation was (1) the absence of megafaunal zones $\mathrm{C}_{2}$ and $\mathrm{D}$ from the lower part of the Little Flat Formation in the Chesterfield Range of southeastern Idaho, from the lower part of the Deep Creek Formation in the Deep Creek Mountains of southeastern Idaho, and from the lower part of the Little Flat Formation at Old Laketown Canyon in northeastern Utah; and (2) the apparent absence of Mamet microfossil Zones 8 through 12 from the lower part of the Little Flat Formation in the Chesterfield Range (Dutro and Sando, 1963, fig. 6; Sando, 1967b, p. D36; Sando and others, 1969, p. E20). Moreover, the interpretation seemed consistent with the well-documented major unconformity between the Madison Group and overlying rocks of Late Mississippian and Pennsylvanian age on the Cordilleran platform to the east.

Subsequent discovery of conodonts of Osagean aspect in beds previously regarded as middle Meramecian in

\footnotetext{
${ }^{1}$ Universite de Montreal.
}

age in the lower part of the Little Flat Formation at Old Laketown Canyon (C. A. Sandberg, written commun., 1969) and in beds of similar lithology, stratigraphic position, and megafauna in the upper member: of the McGowan Creek Formation in the Lost River Range of east-central Idiho (Sandberg, 1975, p. E9) contradicted the previons stratigraphic interpretation. In the summer of $1975, \mathrm{C}$. A. Sandberg made new collections of microfossil samples in the lower part of the Little Flat Formation at Little Flat Canyon in the Chesterfield Range from the disputed interval, where foraminiferal evidence seemed to require a major unconformity between the Lodgepole Limestone and the Little Flat Formation. 'The purpose of this report is to record the results of the new investigations and to revise the previous interpretation of the stratigraphy, which has an important bearing on the geologic history and economic potential of the Mississippian System in Idaho and Utah. Some of the new data contained herein are used in a companion paper on Mississippian car:bonate shelf margins (Rose, 1976).

Responsibility for fossil identifications in this report is as follows: foraminifers and algae (Mamet), corals (Sando), brachiopods (Dutro), cephalopods (M. Gordon, $\mathrm{Jr}$.), and conodonts (Sandberg).

\section{LITTLE FLAT CANYON AND OLD LAKETOWN CANYON SECTIONS}

Fossiliferous sequences at Little Flat Canyon in the Chesterfield Range of southeastern Idaho and at Old Laketown Canyon in northeastern Utah (figs. 1 and 2) hold the keys to a revised interpretation of the history of the Osagean-Meramecian interval in the miogeosyncline of Idaho and Utah.

\section{Little Flat Canyon}

In the Little Flat Canyon section, the upper 26.5 feet $(8.1 \mathrm{~m})$ of the Lodgepole Limestone (unit 12 of Dutro 


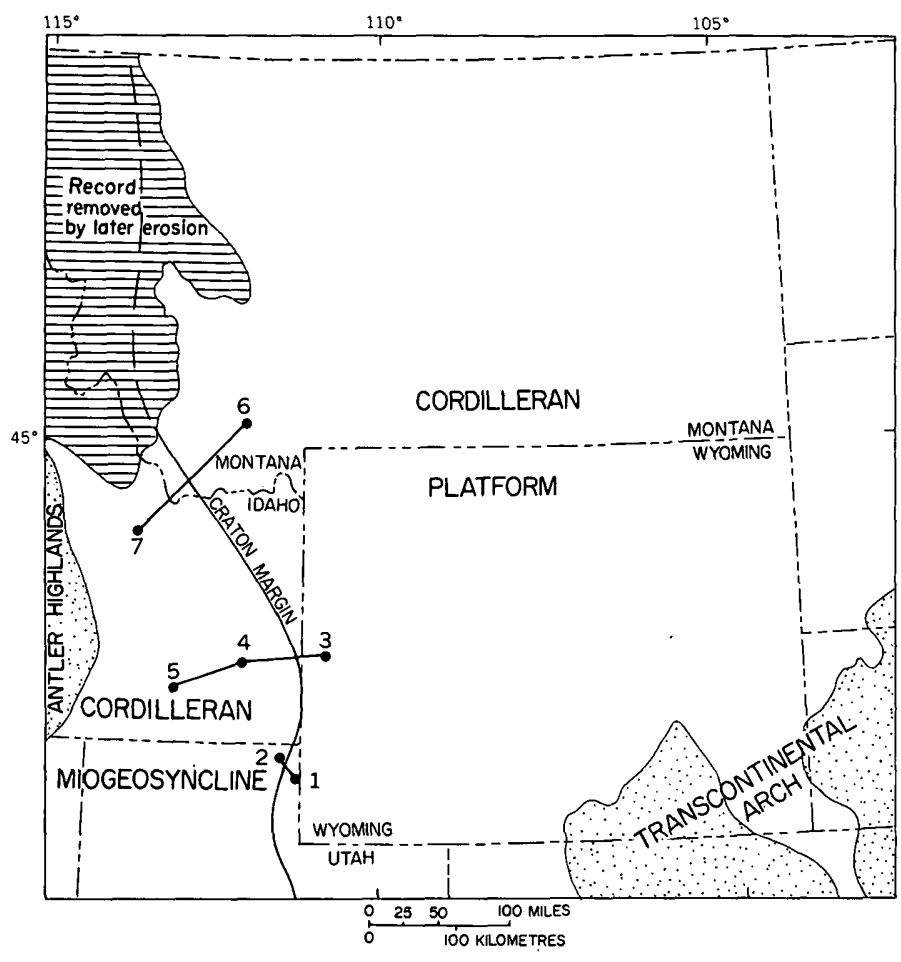

Frgure 1.-Paleotectonic map showing location of key stratigraphic sections of Mississippian rocks in Montana, Idaho, Wyoming, and Utah:

1. Brazer Canyon section; sec. 20 , T. 11 N., R. 8 E., Rich County, Utah (Sando and others, 1959; Sando and Dutro, 1960).

2. . Old Laketown Canyon section; sec. 32, T. 13 N., R. 6 E., Rich County, Utah (Sando and others, 1959).

3. Haystack Peak-Covey Cutoff section; sec. 19, T. 34 N., R. 117 W., Lincoln County, Wyoming (modified from Sando and Dutro, 1960; Sando and others, 1975).

4. Little Flat Canyon section; secs. 17, 20, and 29, T. 7 S., R. 40 E., Bannock County, Idaho (Dutro and Sando, 1963).

5. Water Canyon-Hunter Canyon section; secs. 35 and 26 , T. 9 S., R. 31 E., Power County, Idaho (modified from Carr and Trimble, 1961).

6. Baldy Mountain section; secs. 26,27 , and 35, T. 7 S., R. 3 W., Madison County, Montana (Sando and Dutro, 1960; Sando and others, 1975).

7. Hawley Mountain section; secs. 24 and 25 , r. 9 N., R. 26 E., Butte County, Idaho (Mamet and others, 1971; Sandberg, 1975).

and Sando, 1963, p. 1969) consists of thick-bedded coarse-grained crinoidal limestone (biosparite and biomicrite) that contains abundant corals and brachiopods. This fauna, listed by Dutro and Sando (1963, p. 1978; USGS 18647-PC, 18648-PC, 18649-PC), is representative of megafaunal Zone $\mathrm{C}_{1}$, which is of early Osagean age. Sandberg samples $\mathrm{CH}-10 \mathrm{~A}$ and $\mathrm{CH}-$ $10 \mathrm{~B}$, collected 3 feet $(1 \mathrm{~m})$ below the top of the Lodgepole, contain the following early Osagean (pre-Burlington) conodonts :
Preudopolygnathus primus Branson and Mehl [sensu

Butler, 1973, pl. 57, figs. 17, 18] _................---- 14

Polygnathus communis communis Branson and Mehl _..- 37

"Spathognathodus" elongatus (Branson and Mehl)

[sensu Thompson, 1967, pl .1, fig. 15] -...-.- 3

"S." pulcher (Branson \& Mehl) [sensu Thompson, 1967,

pl. 1, figs. 1, 4]

Pelekysgnathus bultyncki (Groessens) ?-broken _..--- 1

The Lodgepole Limestone is overlain, seemingly conformably, by the phosphatic silty member of the Little Flat Formation (as used herein, fig. 2). 'The phosphatic silty member is 126 feet $(38.1 \mathrm{~m})$ thick. At the base of the member is 28 feet $(8.5 \mathrm{~m})$ of poorly exposed, platy calcareous quartz siltstone and finegrained sandstone, which was investigated by trenching (unit 13 of Dutro and Sando, 1963, p. 1969). Phosphatic nodules are present in the siltstone directly above the top of the Lodgepole, and the soil has a red color like that produced by weathering of rare-earth minerals associated with phosphate. Fossils collected from float (Dutro and Sando, 1963, p. 1978, USGS $18650-\mathrm{PC})$ in the lower 20 feet $(6.1 \mathrm{~m})$ of this unit include the brachiopod Leiorhynchoidea cf. L. carbonifera (Girty) and indeterminate brachiopods and cephalopods. The age of this assemblage is not precisely determinable.

The next succeeding unit is 4 feet (1.2 m) of cherty, silty, fine-grained limestone (biomicrite) that contains clumps of phosphate (unit 14 of Dutro and Sando, 1963 , p. 1969). This unit previously was thought to be of middle Meramecian age (Mamet Zones 13-14) on the basis of foraminifers in USGS 18651-PC, which was collected from float (Sando and others, 1969, p. E3). Sandberg sample CH-11A, collected 1 foot (0.3 $\mathrm{m})$ above the base of the unit, contains the following conodonts:

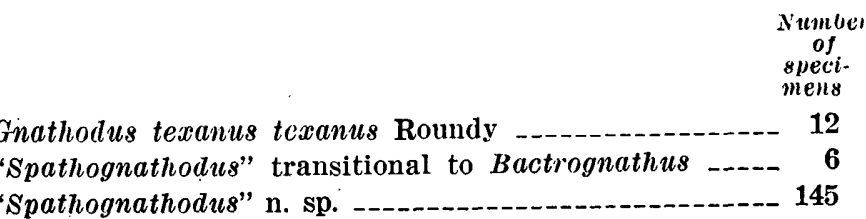

According to Sandberg, the possible age range of this conodont assemblage is late Osagean (Keokuk) to early Meramecian (Warsaw-Salem). Collinson, Scott, and Rexroad (1962, p. 23, chart 3) reported Gnathodus texanus as low as the uppermost Burlington, but $\mathbf{H}$. $\mathbf{R}$. Lane (oral commun., 1975) found that this species does not occur below the overlying Keokuk Limestone. The "Spathognathodus" in this sample is new, but some specimens have a Bactrognathus-like twist of the posterior tip. Inasmuch as Bactrognathus does not 


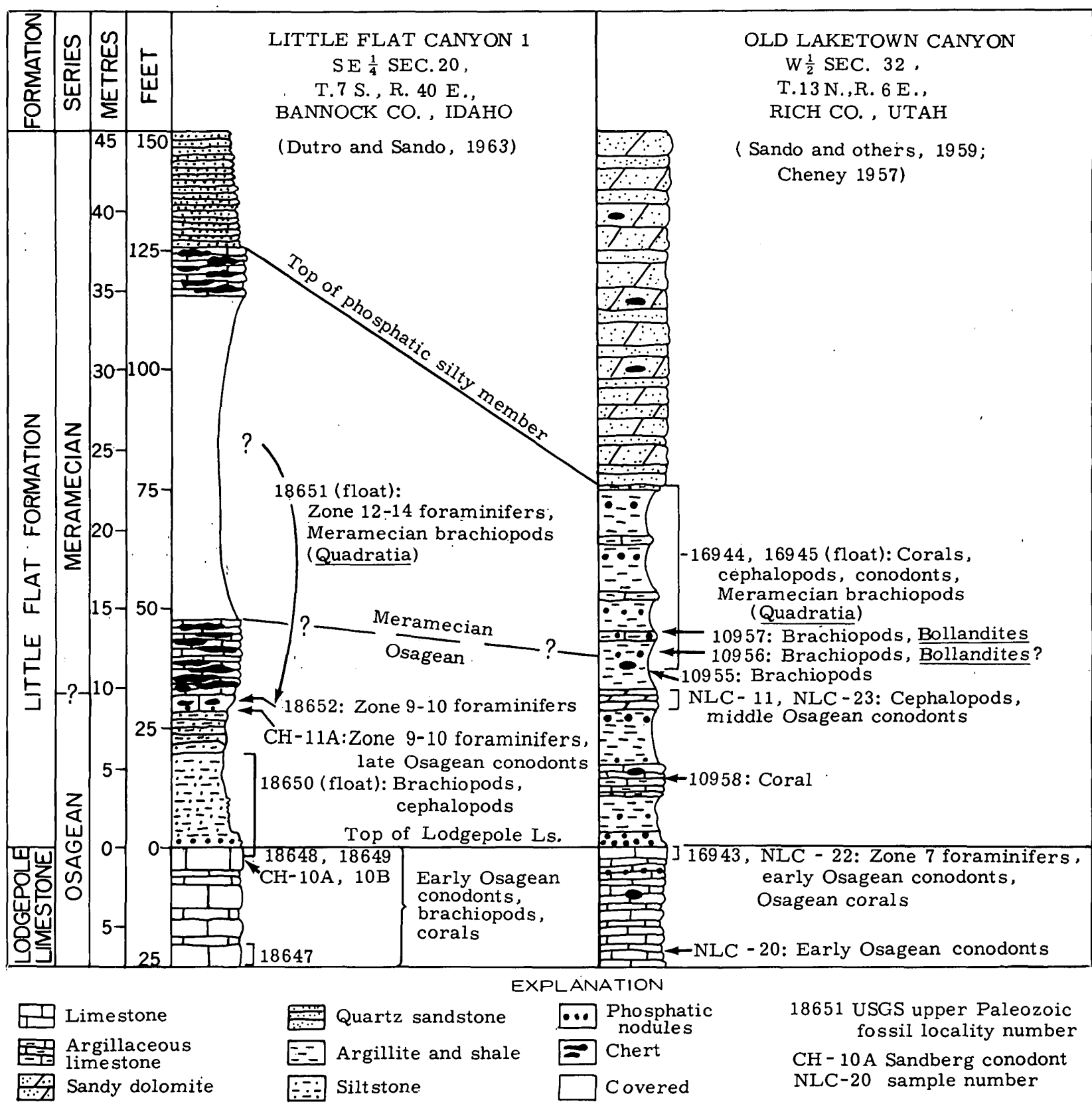

Figure 2.-Correlation of starved-basin facies between Little Flat Canyon and Old Laketown Canyon sections (fig. 1, secs. 4 and 2, respectively), showing details of lithology and faunal evidence for age determinations.

range higher than the Keokuk, sundberg prefers a late Osagean (Keokuk) age for this fauna.

In addition to the conodonts, $\mathrm{CH}-11 . \mathrm{A}$ yielded the following foraminifers and algae:

\section{Brunsia sp.}

Calcisphaera laevis Williamson.

Calcisphaera pachysphaerica (Pronina).

Earlandia sp.

Earlandia of the group E. clavatula (Howchin).

Earlandia of the group $E$. elegans (Rauzer-Chernoussova).

Earlandia of the group $E$. moderata (Malakhova).

Endothyra sp.

Eoforschia sp. (one fragment).
Eovolutina sp.

Inflatoendothyra sp.

Issinella sp.

Latiendothyra sp.

Medioendothyra sp.

Palaeoberesella sp.

cf. Paradainella? sp.

Parathurammina sp.

Priscella of the group $P$. prisca (Rauzer-Chernoussova and Reitlinger).

Pseudocornuspira sp.

primitive Pseudoendothyridae?

Radiosphaerina sp.

Septaglomospiranella sp.

Tournayella sp. 
The possible range of this assemblage is Mamet Zones $9-10$, which indicates that the age is late Osagean or early Meramecian, that is, just above or just below the Tournaisian-Viséan boundary of Europe.

USGS 18652-PC, collected from the upper 1 foot $(0.3 \mathrm{~m})$ of the same limestone unit, contains an indeterminate spiriferoid brachiopod and the following foraminifers and algae (forms marked by asterisks identified by Betty Skipp in another split of the sample) :

Calcisphaera laevis Williamson.

Calcisphaera pachysphaerica (Pronina) (scarce).

Earlandia sp.

Endothyra sp.

cf. Inflatoendothyra sp.

Issinella sp.

*Latiendothyra sp.

Palaeoberesella sp.

*Paradainella? sp.

Parathurammina sp.

Priscella of the group P. prisca (Rauzer-Chernoussova and

Reitlinger).

*Pseudocornuspira sp.

Radiosphaerina sp.

*Septaglomospiranella sp.

*Tournayella? sp.

This sample is nearly identical in rock type and microfossil assemblage with that in $\mathrm{CH}-11 \mathrm{~A}$ and also represents a Mamet Zone 9-10 range.

Overlying the 4-foot limestone unit is 16 feet $(4.9 \mathrm{~m})$ of unfossiliferous, thin-bedded, very cherty finegrained limestone (unit 15 of Dutro and Sando, 1963, p. 1969). Above the 16 -foot limestone unit is a covered interval 68 feet $(20.7 \mathrm{~m})$ thick (unit 16 of Dutro and Sando, 1963, p. 1969). This unit is difficult to evaluate because of a Tertiary gravel cap on the unit and the failure of exploratory trenches to reach bedrock. Float material on the unit consists of platy siltstone and finegrained sandstone, like that in unit 13, and fine-grained limestone and black chert, like that in unit 15. The unit is probably mainly siltstone and subordinate interbedded cherty limestone.

USGS 18651-PC, collected from float lower in the section (unit 14), is now thought to have come from the 68-foot covered interval (unit 15), although it may have come from higher in the sequence. This collection contains bryozoans, brachiopods, and ostracodes listed by Dutro and Sando (1963, p. 1978). The matrix in which the fossils occur is cherty, silty biomicrite. Important megafossils in this assemblage are the brachiopods Leiorhynchoidea cf. L. carbonifera (Girty), which, on the basis of current evidence, ranges from Osagean into the Meramecian, and Quadratia cf. Q. hirsutiformis (Walcott), a characteristic Meramecian form. Foraminifers and algae in USGS 18651-PC are as follows:

Calcisphaera pachysphaerica (Pronina).

Earlandia sp.

Earlandia vulgaris (Rauzer-Chernoussova and Reitlinger).

Epistacheoides sp.

Endothyra of the group E. bowmani Phillips emend. Brady.

Eoendothyranopsis sp.

cf. Koninckopora sp.

probably Endothyranopsis sp.

Stacheia? skimoensis Mamet and Rudloff.

Tetrataxis sp.

This is a middle Viséan (middle Meramecian) assemblage, which has a possible range of Mamet Zones $12-14$.

Above the 68 -foot $(20.7-\mathrm{m})$ covered interval is 10 feet $(3 \mathrm{~m})$ of unfossiliferous, thin-bedded, cherty finegrained limestone (unit 17 of Dutro and Sando, 1963, p. 1969). The overlying beds of platy, calcareous, finegrained quartz sandstone, beginning at the 125-foot level on figure 2 , belong to the sandstone member of the Little Flat Formation. USGS 18653-PC, collected 308-323 feet (93.9-98.5 m) above the base of the sandstone member, contains bryozoans, brachiopods, and gastropods (Dutro and Sando, 1963, p. 1978), and the following foraminifers and algae, which have a possible range of Mamet Zones 10-13:

\section{Calcisphaera laevis Williamson.}

Calisphaera pachysphaerica (Pronina).

Earlandia of the group $E$. moderata (Malakhova).

Earlandia of the group E. clavatula (Howchin).

Earlandia of the group $E$. vulgaris (Rauzer-Chernoussova and Reitlinger)

Endothyra sp.

cf. Eoparastaffella? (or could be a section of Skippella? sp.). Globoendothyra sp. (fragments).

Issinella sp.

Palaeoberesella sp.

Pseudocornuspira sp.

Skippella sp.

USGS 186:4-PC, collected 347 feet $(105.8 \mathrm{~m})$ above the base of the sandstone member, contains Meramecian brachiopods (Dutro and Sando, 1963, p. 1978) and the following foraminifers and algae, which have a possible range of Mamet Zones 10-13:

Calcisphaera laevis Williamson.

Calcisphaera pachysphaerica (Pronina).

Earlandia of the group E. clavatula (Howchin).

Endothyra sp.

Globoendothyra sp. (fragments).

Issinella sp.

Pseudocornuspira sp.

Priscella sp.

Skippella sp.

USGS 1865ّ-PC, collected 362 feet $(110.3 \mathrm{~m})$ above the base of the sandstone member, contains brachiopods (Dutro and Sando, 1963, p. 1978) and middle Mera- 
mecian (St. Louis) microfossils, which have a possible range of Mamet Zones 13-14 (Sando and others, 1969, p. E3). This is the lowest collection from the Little Flat Formation that can be correlated precisely with foraminifer and conodont collections from the base of the Middle Canyon Formation, above the McGowan Creek Formation in the Lost River Range (Mamet and others, 1971, p. 24, 25; Sandberg, 1975, p .E9).

Interpretation.-The revised distribution of diagnostic fossils in the Little Flat Canyon section supports the interpretation that the phosphatic silty member represents essentially continuous deposition beginning in early or middle Osagean time and extending into early Meramecian time. The abrupt lithologic break at the top of the Lodgepole Limestone, originally interpreted as a regional disconformity, can now be regarded as the result of a rapid change in cnviromment from a shelf-carbonate milieu to a starved basin receiving fine-grained, predominantly terrigenous sediments. The phosphatic character of the lower part of the silty member supports the concept of slow deposition in a starved basin. Although no fossils of early or middle Osagean age have been identified, this time interval could be represented in the undated lower 28 feet $(8.5 \mathrm{~m})$ of the siltstone member, which appears to represent continuous deposition.

The Osagean-Meramecian boundary is tentatively placed at the top of the 16 -foot $(4.9-\mathrm{m})$ limestone unit 48 feet $(14.6 \mathrm{~m})$ above the base of the phosphatic silty member. This placement is based on the occurrence of Zone 9-10 foraminifers and late Osagean conodonts below the boundary and on the occurrence of Quadratia cf. Q. hirsutiformis (Walcott) in float from above the boundary (fig. 2). Quadratia hirsutiformis (Walcott) is an important species in the Meramecian part of the Moorefield Formation of Arkansas, and the form in USGS $18651-P C$ is very similar if not conspecific. Although the first occurrence of $Q$. hirsutiformis is not known to the same degree of certainty as the first occurrences of key conodont and foraminifer species, the presence of $Q$. cf. $Q$. hirsutiformis suggests an early Meramecian age for the poorly exposed upper part of the phosphatic silty member at this locality. The inferred boundary position also provides a good stratigraphic correlation with the Old Laketown Canyon section, if a similar rate of sedimentation is assumed for both localities. The overlying sandstone member of the Little Flat Formation contains early to middle Meramecian fossils 308-362 feet (93.3-110.3 in) above the base.

\section{Old Laketown Canyon}

In the Old Laketown Canyon section, the upper 22 feet $(6.7 \mathrm{~m})$ of the Lodgepole Limestone consists of sparsely cherty, thin-bedded fine-grained limestone interbedded with medium- to coarse-grained crinoidal limestone (biomicrite and biosparite). USGS 16943PC, from the upper 2 feet $(0.6 \mathrm{~m})$ of the Lodgepole, contains the Osagean corals Homalophyllites sp. and Vesiculophyllum sp. The same collection also yielded Osagean (Mamet Zone $\tau$ ) foraminifers and algae (Sando and others, 1969, p. E3). Sandberg sample NLC-22, collected 0.5 foot $(0.2 \mathrm{~m})$ below the top of: the Lodgepole, contains the following early Osagean (pre-13urlington) conodont fauna:

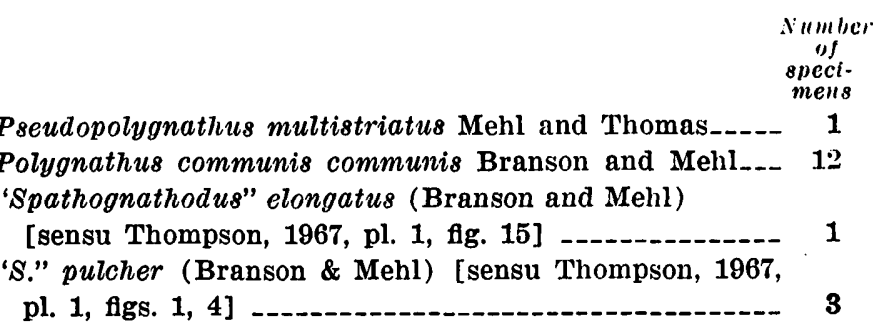

Sandberg sample NLC-20, collected 22 feet $(6.7 \mathrm{~m})$ below the top of the Lodgepole, contains a similar carly Osagean (pre-Burlington) conodont fauma:

Pseudopolygnathus primus Branson and Mehl [sensu

Butler, 1973, pl. 57, figs. 17-18]

Pelekysgnathus bultyncki (Groessens) -..-_-_-_-.-.-- 1

Polygnathus communis communis Branson and Mehl_..- 11

"Spathognathodus" elongatus (Branson and Mehl)

[sensu Thompson, 1967, pl. 1, fig. 15] ---.---_-- 10

"S." pulcher (Branson and Mehl) [sensu Thompson,

1967, pl. 1, figs. 1, 4] -_. 11

The Lodgepole Limestone is overlain, seemingly conformably, by a poorly exposed sequence of phosphatic shale and mudstone and silty fine-grained limestone that forms the lower 76.2 feet $(23.2 \mathrm{~m})$ of the Little Flat Formation. This sequence was trenched and described in detail by F. J. Anderson, R. G. Waring, and R. A. Smart (in Cheney, 1957, p. 38).

No identifiable fossils were collected from the lower 29 feet $(8.8 \mathrm{~m})$ of the sequence, but middle Osagean (Burlington) conodont faunas were recovered from cherty dolomite 29-33 feet $(8.8-10.1 \mathrm{~m})$ above the base.

Sandberg sample NLC-11, 29-33 feet (8.8-10.1 m) above the base of the Little Flat Formation, yielded:

\begin{tabular}{|c|c|}
\hline & $\begin{array}{c}\text { Number } \\
\text { of } \\
\text { speci- } \\
\text { mells }\end{array}$ \\
\hline $\begin{array}{l}\text { Doliognathus latus Branson and Mehl } \\
\text { Polygnathus communis communis Branson and Mehl } \\
\text { "Spathognathodus" pulcher (Branson and Mehl) [sensu } \\
\text { Thompson, 1967, pl. } 1 \text {, figs. 1, 4] }\end{array}$ & $\begin{array}{r}2 \\
-\quad 48\end{array}$ \\
\hline
\end{tabular}

Sandberg sample NLC-23, about 30 feet $(9.1 \mathrm{~m})$ above the base of the Little Flat Formation, yielded: 


\begin{tabular}{|c|c|}
\hline & $\begin{array}{c}\text { Number } \\
\text { of } \\
\text { speci- } \\
\text { mens }\end{array}$ \\
\hline Dolisgnathus latus Branson and Mehl -- & 2 \\
\hline $\begin{array}{l}\text { Polygnathus communis communis Branson and Mehl--- } \\
\text { "Spathognathodus" pulcher (Branson and Mehl) [sensu }\end{array}$ & $-\quad 80$ \\
\hline $\begin{array}{l}\text { "Spathognathodus" pulcher (Branson and Mehl) [sensu } \\
\text { Thompson, 1967, pl. 1, figs. 1, 4] }\end{array}$ & 12 \\
\hline
\end{tabular}

Sample NLC-11 also contains the cephalopods Beyrichoceras sp. and Djhaprakoceras sp. (identified by Mackenzie Gordon, Jr.). These two genera occur in concretions in the phosphatic shale unit of the Deseret Limestone at. Flux Canyon in the Stansbury Mountains, Utah (Petersen, 1969). Except for its occurrences in Utah, Djhaprakoceras is not well known outside the lower Viséan of the U.S.S.R. Beyrichoceras, however, is widely distributed in Europe, North America, and Australia, and has been reported from localities that can be dated independently by conodonts (Matthews, 1971; Rexroad and Scott, 1964; Jenkins, 1974). It is now demonstrable, largely through conodont evidence, that the genus ranges through the Osagean and Meramecian and that precise age assignments must be made at a specific level. At Flux Canyon, just below the zone of cephalopod-bearing concretions (Petersen, 1969), Sandberg collected sample FLUX-3, which contains a middle Osagean (Burlington) conodont fauna similar to that in his samples NLC-11 and NLC-23 from Old Laketown Canyon. Sample FLUX-3 includes Doliognathus latus. Polygnathus communis communis, Hindeodella segaformis, Scaliognathus anchoralis Branson and Mehl, and Pseudopolygnathus triangulus pinnatus Voges.

USGS 10955-PC, collected from mudstone 37 feet $(11.3 \mathrm{~m})$ above the base of the phosphatic silty member, contains Leiorhynchoidea cf. L. carbonifera (Girty). USGS 10956-PC, collected from phosphatic mudstone 41 feet $(12.5 \mathrm{~m})$ above the base of the phosphatic shale sequence, contains Leiorhynchoidea cf. L. carbonifera. (Girty) and the cephalopod Bollandites? sp.

USGS 10957-PC, collected from phosphatic silty limestone 44 feet $(13.4 \mathrm{~m})$ above the base of the phosphatic shale sequence, contains Leiorhynchoidea cf. $L$. carbonifera (Girty), Bollandites sp., fish fragments, and the same new species of "Spathognathodus" that is found in samples NLC-23 and CH-11A. According to Sandberg, the upper range of the conodont species is not known. According to Mackenzie Gordon, Jr. (oral commun., 1976), Bollandites occurs in the Viséan of England and Europe, and its few occurrences in North America (Alaska, Indiana) are Meramecian.

USGS 16944-PC and 16945-PC, collected from float in the upper half of the phosphatic silty member, contain a moderately large fauna of corals, bryozoans, brachiopods, and cephalopods that were listed by Sando, Dutro, and Gere (1959, p. 2763). Most of these fossils are not diagnostic for age determination except for Quadratice cf. Q. hirsutiformis (Walcott), which is regarded as a Meramecian indicator. This species occurs in the Little Flat Canyon section with foraminifers and algae of Mamet Zones 12-14. In northern Arkansas, the species certainly ranges as high as Mamet Zone 16i. Leiorhynchoidea cf. L. carbonifera (Girty) is also present. The only conodont (Ligonodina? sp.) found in this assemblage is not diagnostic for dating the fauna.

Overlying the phosphatic silty member is about 500 feet $(152.4 \mathrm{~m})$ of interbedded thick-bedded fine- to medium-grained quartz sandstone and sandy, cherty crinoidal dolomite that have not yielded identifiable fossils (unit B of Sando and others, 1959, p. 2763). Middle Meramecian fossils (megafaunal Zone E, Mame: Zone 13) are found in limestones (unit C of Sando and others, 1959, p. 2763) above the sandy dolomitic unit.

Interpretation.-The lithic and faunal sequence in the lower part of the Little Flat Formation at Old Laketown Canyon is similar to that at Little Flat Canyon, although the Old Laketown Canyon sequence, which is closer to the craton margin (fig. 1), is thinner, more shaly, and more phosphatic. Only middle Osagean faunas have been found in the lower 33 feet (10.1 $\mathrm{m})$ of the phosphatic silty member, but the undated lower 29 feet $(8.8 \mathrm{~m})$ probably includes beds of early Osagean age. Evidence for this dating is the occurrence of early Osagean conodonts 1 foot $(0.3 \mathrm{~m})$ above the base of the phosphatic shale at East Canyon (SW1/4 SE $1 / 4$ NW1/4 sec. 17 , T. 9 N., R. 2 E., Cache County, Utah), about 30 miles $(48 \mathrm{~km})$ southwest of Old Laketown Canyon.

The presenre of Quadratia cf. Q. hirsutiformis (Walcott) in the upper 36 feet $(10.9 \mathrm{~m})$ of the Old Laketown Canyon sequence indicates a Meramecian age for this interval. A tentative Osagean-Meramecian boundary is placed 40 feet $(12.2 \mathrm{~m})$ above the base of the phosphatic silty member, below the occurrence of $\mathrm{Bol}$ landites and above Osagean conodonts. Like the sequence at Little Flat Canyon, the Old Laketown Canyon sequence probably represents essentially continuous deposition in a starved basin from early Osagean into early Meramecian time after an abrupt change from shelf carbonate deposition. Although this is a reasonable interpretation, on the basis of present data, the faunal evidence is not sufficient to demonstrate that all the Osagean-Meramecian time interval is represented by sedimentary strata. Undetected discontinui- 
ties may be present and, indeed, might be expected in a starved-basin depositional setting.

\section{REGIONAL SIGNIFICANCE}

Fine-grained terrigenous sequences similar in lithology and faunal content to the Little Flat Canyon and Old Laketown Canyon sequences have been identified in the lower part of the Deep Creek Formation in the Deep Creek Mountains and in the upper member of the McGowan Creek Formation in the Lost River Range (fig. 3) in eastern Idaho. A similar sequence also is present in the lower part of the Deseret Limestone in central Utah. Evidently this Osagean and Meramecian terrigenous facies was widespread in the Cordilleran miogeosyncline of Idaho and Utah.

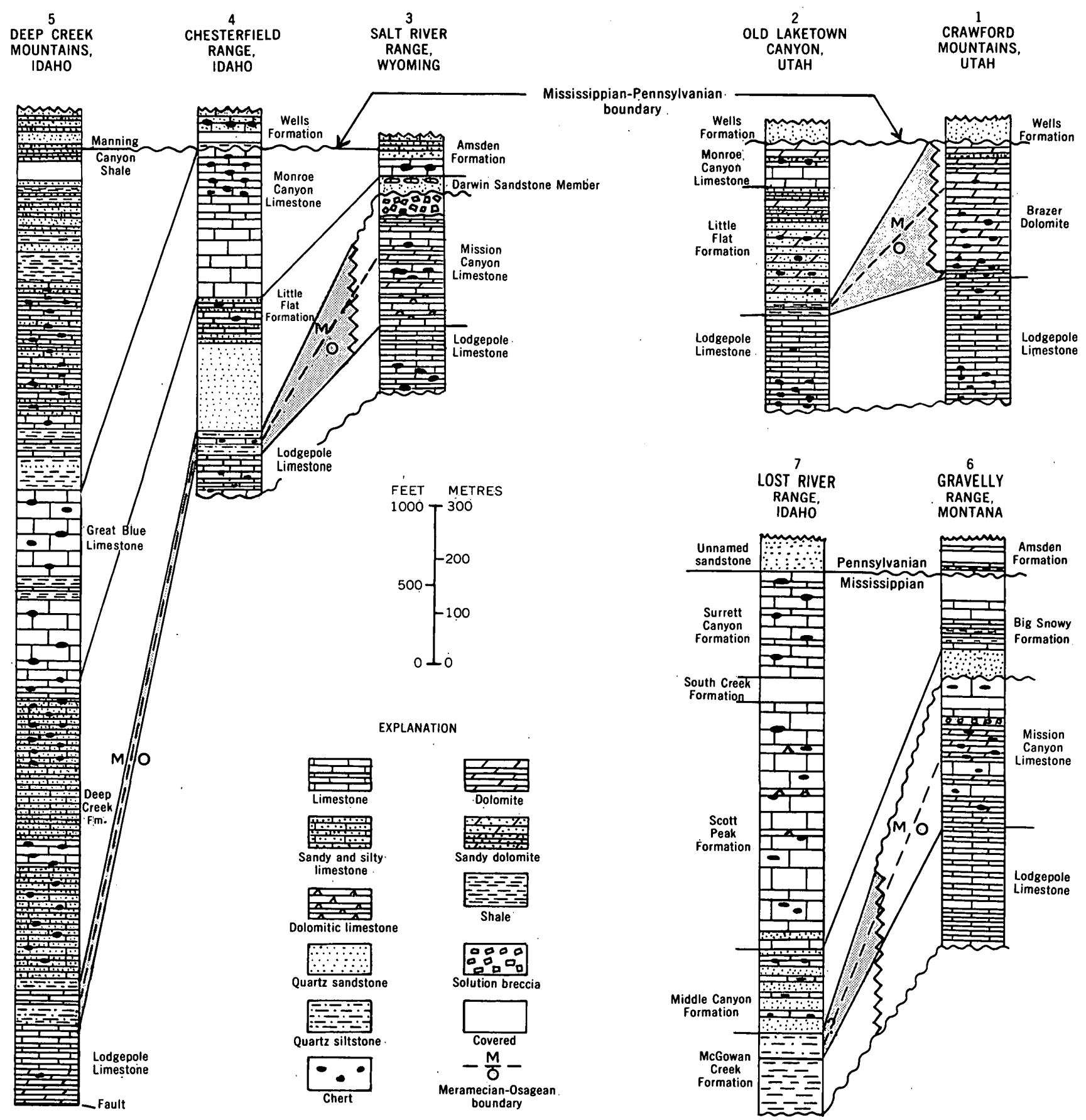

FIqURE 3.-Correlation of key stratigraphic sections of Mississippian rocks across the craton margin in Montana, Idaho, Wyoming, and Utah. Gray pattern denotes starved-basin facies. Locations of sections and sources of information shown on figure 1. 


\section{Correlation}

Correlation with Mississippian sequences on the Cordilleran platform (figs. 1 and 3) indicates that the Osagean-Meramecian terrigenous interval is essentially equivalent to the uppermost part of the Lodgepole Limestone and all of the Mission Canyon Limestone of southwestern Montana and western Wyoming and to the Brazer Dolomite of northeastern Utah. To the west, in the area adjacent to the Antler Highlands (Antler orogenic highland of Poole, 1974), equivalent strata are found in the Copper Basin Group of Paull and others (1972) and possibly in the lower part of the White Knob Limestone. Figure 4 shows the terrigenous facies in the context of inferred temporal relations of Mississippian formations throughout the northern Rocky Mountains region of the United States. Figure 4 also revises the Osagean-Meramecian boundary from a position at the base of Mamet Zone 10 to a position low in Zone 10, on the basis of unpublished studies by B. L. Mamet.

Correlations with the Mission Canyon Limestone and the Brazer Dolomite on the Cordilleran platform imply marked differences in lithic facies and in sedimentation rates between the miogeosyncline and the platform during Osagean and Meramecian time. The finegrained terrigenous facies is only about 75-490 feet (23-150 m) thick as compared with equivalent carbonate rocks on the platform that are as much as 1,000 feet $(300 \mathrm{~m})$ thick. Moreover, the platform sequences are truncated by a regional unconformity, whereas the upper part of the miogeosyncline sequence includes strata deposited during the onset of erosion on the platform. The reduced thickness and the commonly phosphatic character of the miogeosynclinal terrigenous facies suggest deposition in a starved basin.

\section{Interfingering of starved-basin and shelf-carbonate facies}

Complete sequences showing interfingering of the miogeosynclinal starved-basin facies with the shelfcarbonate facies of the Cordilleran platform have not been found. In southeasternmost Idaho and westernmost Wyoming, the Mississippian is buried under a belt of Mesozoic and younger rocks along the craton margin. In the Idaho-Montana border region, structural complexities in Paleozoic outcrop areas provide few opportunities for good stratigraphic sections. However, in the southern part of the Crawford Mountains in northeastern Utah, an interval of phosphate rock and calcareous mudstone about 10 feet $(3 \mathrm{~m})$ thick was found in the lower 60 feet $(18.3 \mathrm{~m})$ of member 1 of the Brazer Dolomite (W. C. Gere, oral commun., 1971).
At Warner Hollow (NE1/4 SE1/4 SW1/4 sec. 31, T. 11 N., R. 8 E., Rich County, Utah), Sandberg found a sequence of interbedded phosphate rock, cherty dolomite, phosphatic limestone, and phosphatic shale about $33 \mathrm{ft}(10 \mathrm{~m})$ thick in the lowermost part of member 1 of the Brazer Dolomite overlying the Lodgepole Limestone. At this locality, Sandberg sample REX-4, collected 5.6 feet $(1.7 \mathrm{~m})$ below the top of the Lodgepole, yielded the following early Osagean (pre-Burlington) conodonts :

\begin{tabular}{|c|c|}
\hline 1 & $\begin{array}{c}\text { Number } \\
\text { of } \\
\text { speci- } \\
\text { mens }\end{array}$ \\
\hline $\begin{array}{l}\text { Polygnathus communis communis Branson and Mehl -- } \\
\text { "Spathognathodus" pulcher (Branson and Mehl) [sensu }\end{array}$ & 6 \\
\hline
\end{tabular}

This assemblage is simlar to an assemblage in Sandberg sample BRZ-1, collected from the top 0.6 feet $(0.2 \mathrm{~m})$ of the Lodgepole Limestone at Brazer Canyon ( NW1/4 sec. 20, T. 11 N., R. 8 E., Rich County, Utah), which contains the following forms:

$\begin{array}{cc}\text { Polygnathus communis communis Branson and Mehl --- } & \begin{array}{c}\text { Number } \\ \text { of } \\ \text { opect- } \\ \text { mens }\end{array} \\ \text { "Spathognathodus" pulcher (Branson and Mehl) } \\ \text { [sensu Thompson, 1967, pl. 1. figs. 1, 4] } \\ \text { Pseudopolygnathus multistriatus Mehl and Thomas --- }\end{array}$

These faunules date the uppermost part of the Lodgepole Limestone in the Crawford Mountains as early Osagean (pre-Burlington) and confirm correlation with the uppermost part of the Lodgepole at Little Flat Canyon and Old Laketown Canyon (see earlier discussion).

At the Warner Hollow locality, Sandberg sample REX -8 , collected 3 feet $(1 \mathrm{~m})$ above the base of the Brazer Dolomite, yielded the following conodonts:

Gnathodus typicus Cooper [sensu Thompson, 1967, pl.

4, figs. 5, 7, 8, 10] _. 126

Hindeodella segaformis Bischoff _._._._._._._._. 71

Pelekysgnathus bultyncki (Groessens) _-_____-_ 2

Polygnathus communis communis Branson and Mehl__._ 700

Pseudopolygnathus nudus Pierce and Langenheim _.... 112

$P$. triangulus triangulus Voges _-_-_- 1

P. n. sp. -

"Spathognathodus" sp. _- 16

This is one of the largest and best preserved early Osagean (pre-Burlington) conodont faunas from the Western United States. It is found in a tongue of the starved-basin facies that interfingers with the lower part of the shelf-carbonate facies. The early Osagean age of this tongue confirms the interpretation that the 


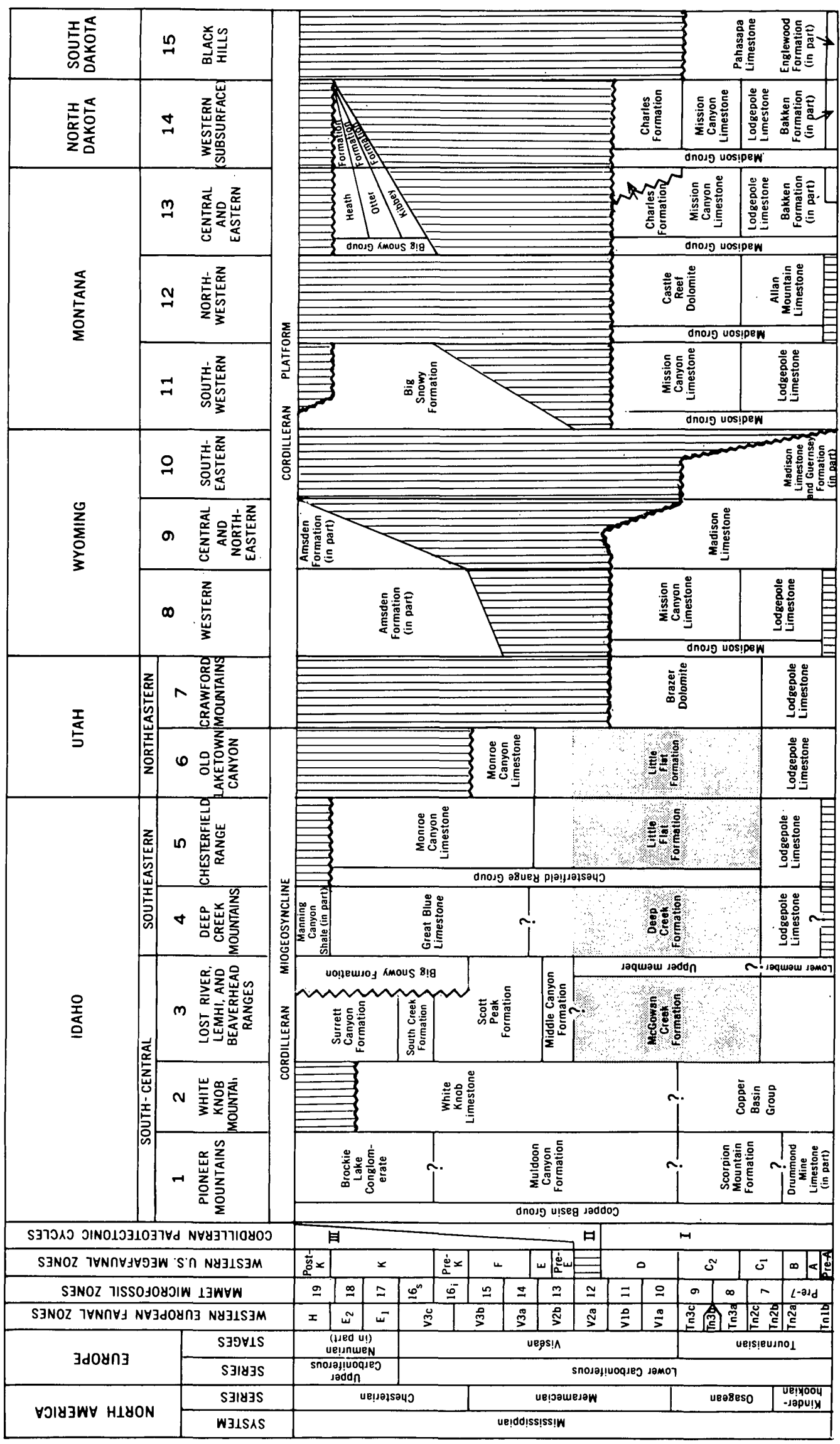

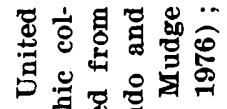

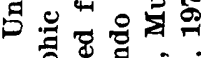

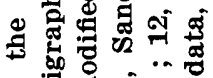
प्ट ธ。

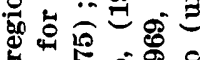

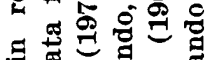

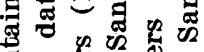

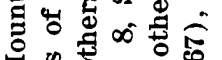

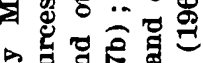

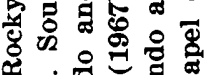

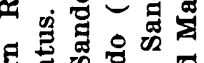

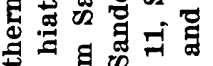

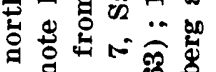

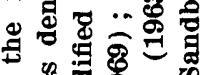

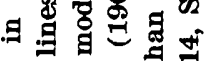

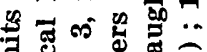

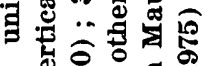

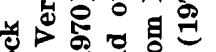

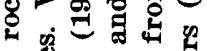

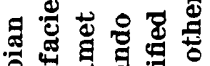

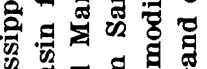

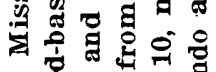

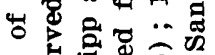

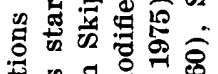

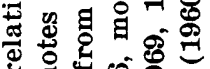
형

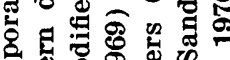

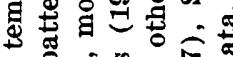

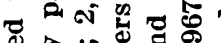

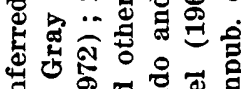

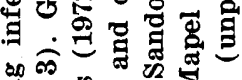

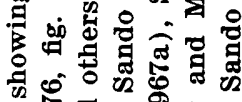

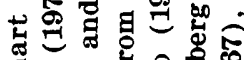

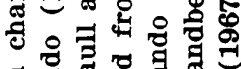
ร 证

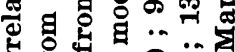

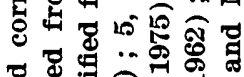

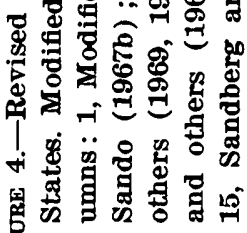

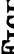




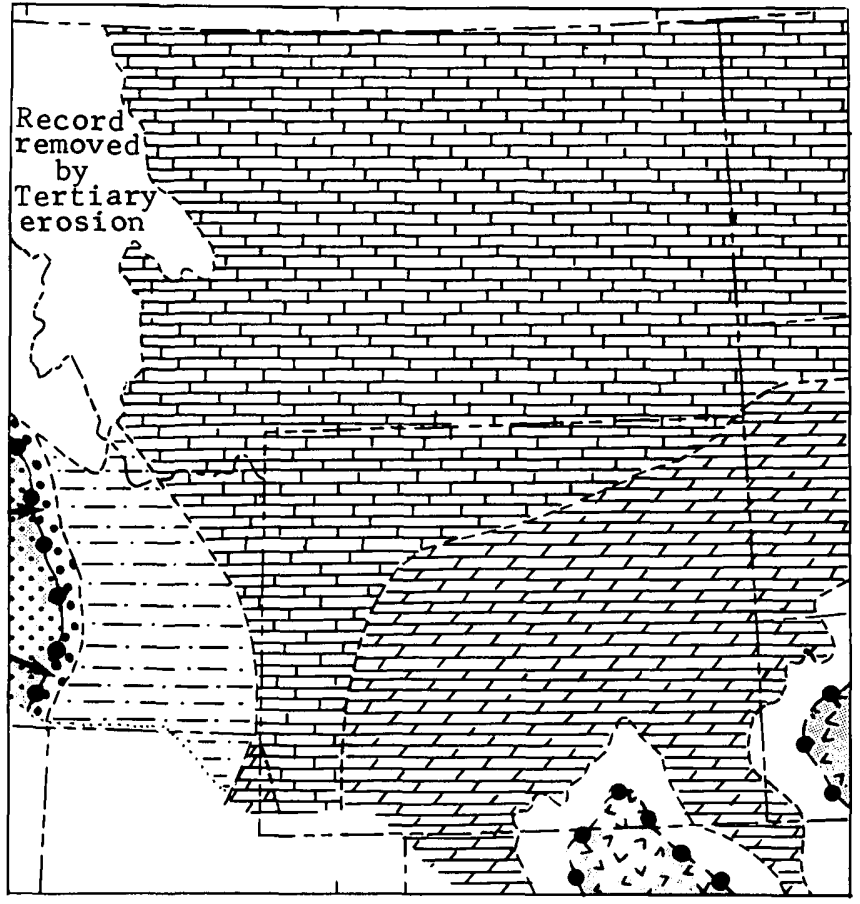

Cycle I, phase 4

Early Osagean (Zones $7-8, \mathrm{Cl}$ )

Figure 5

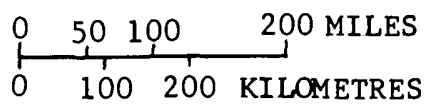

EXPLANATION FOR FIGURES 5 and 6

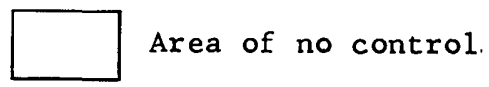

Land areas

Karst lowland composed of Madison Group (Mississippian) carbonate rocks

$\because \because \because$ Upland composed of lower Paleozoic terrigenous rocks

Sr? Upland composed of Precambrian crystalline rocks

Marine depositional areas

$\because \because \because$ Quartz and quartzite boulder and pebble conglomerate and sand

$\Leftrightarrow \because \because$ deposited nearshore in trough adjacent to rising landmass

$=-$ Argillaceous and carbonaceous mud and quartz silt deposited

$=-7$ in trough

Phosphatic quartz silt and mud deposited in starved basin

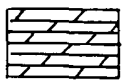

Dolomitized intertidal to subtidal shelf-carbonate sediments

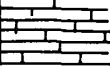

Cyclic intertidal and subtidal shelf-carbonate sediments

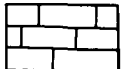

Subtidal carbonate sediments deposited on open marine banks- on shelf

$+^{+}+^{+}+$Evaporitic sediments deposited in lagoons on shelf. H indicates +++ halite facies

$\longrightarrow$ Postulated shoreline, dashed where uncertain

Fraure 5.-Paleogeographic map of northern Rocky Mountains area in early Osagean time. Modified from Sando (1976. fig. 6). 

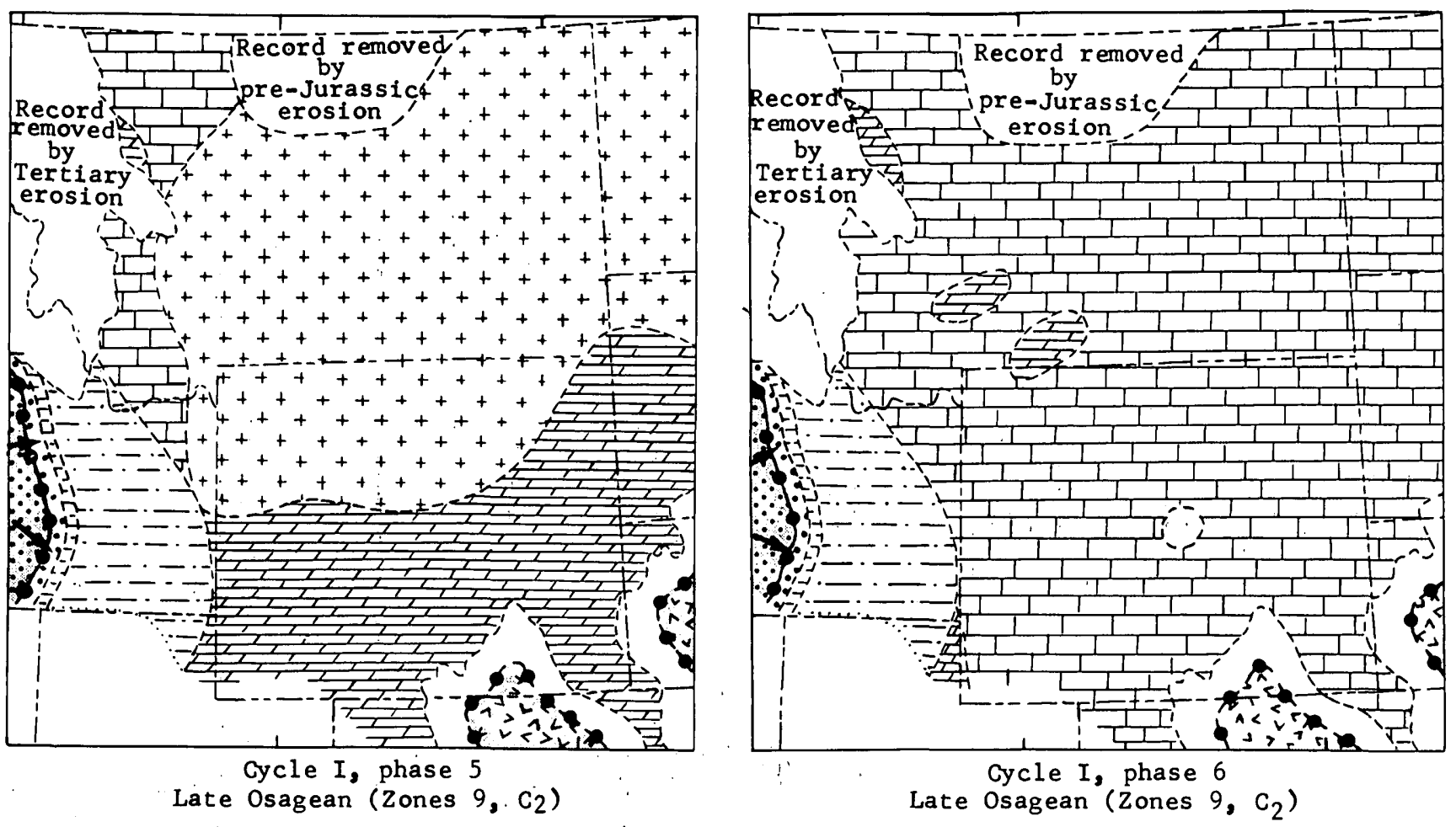

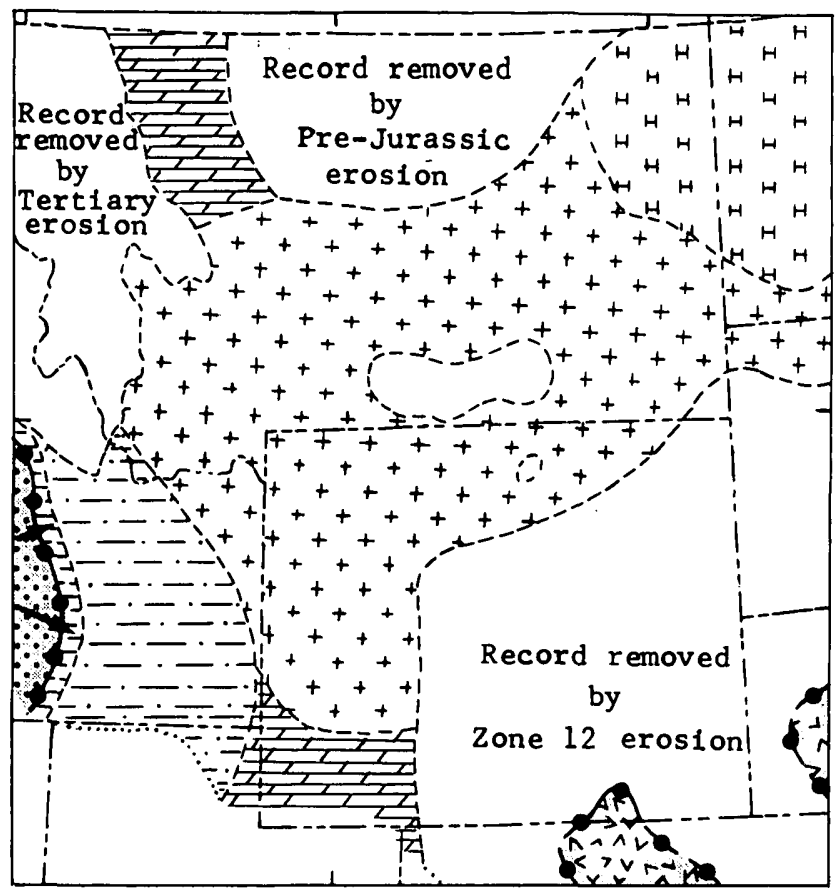

Cycle I, phase 7

Early Meramecian (Zones 10, D)

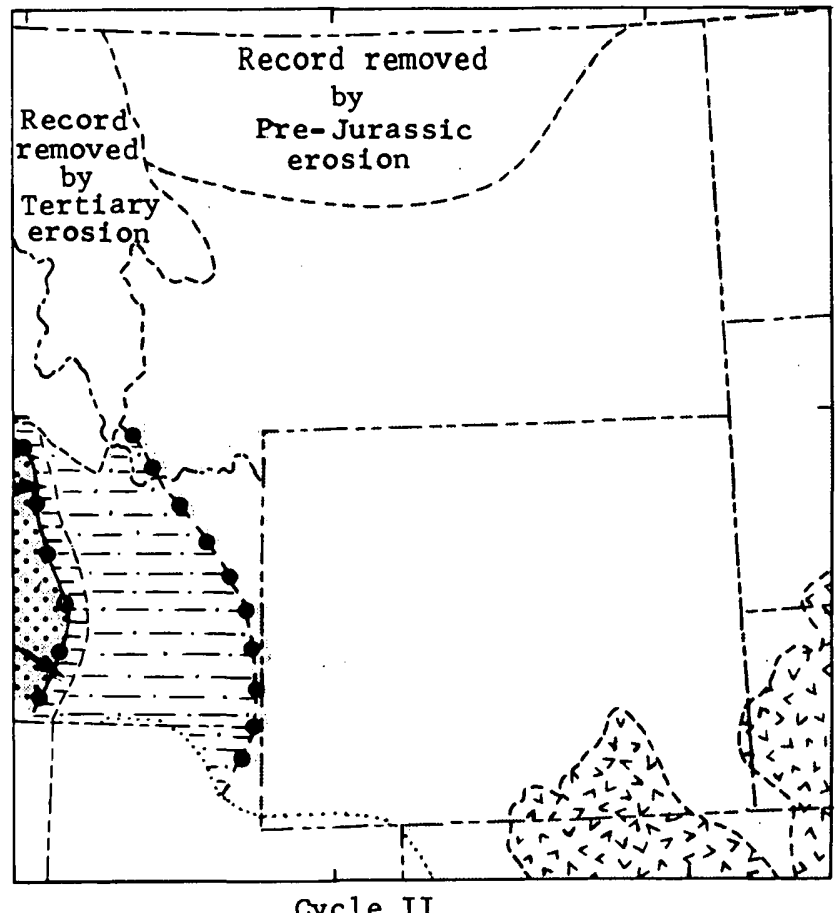

Latest early Meramecian (Zone 12)

\section{$\underbrace{0}_{0} \frac{50100}{100} 200$ MILES}

Figure 6.-Paleogeographic maps of northern Rocky Mountains area in late Osagean and early Meramecian time. Modifled from Sando (1976, fig. 6). 
lower part of the starved-basin facies at Old Laketown Canyon contains beds of early Osagean age.

\section{Paleogeography}

Intervals of Osagean and Meramecian time shown on figures 5 and 6 are the depositional cycles and phases distinguished by Sando (1976). The starvedbasin facies is located between a trough adjacent to the Antler Highlands to the west and the shelf-carbonate and evaporite sediments deposited on the Cordilleran platform to the east. Apparent truncation of shelfsediment patterns by the starved-basin facies on some of the maps on figure 6 suggests possible telescoping due to Laramide thrust faulting.

Provenance of the starved-basin sediments is a subject that needs more detailed study. It would seem unlikely that these sediments came from the west because a belt of deep-water argillite (Poole, 1974) lies between the starved-basin facies and a possible source in the Antler Highlands (fig. 6). A more likely source of the fine terrigenous sediment in the starved basin is the Cordilleran platform to the east, where fine terrigenous debris may have been winnowed by turbulent shallow waters on the carbonate shelf and transported westward into the basin.

\section{REFERENCES CITED}

Butler, Malcolm, 1973, Lower Carboniferous conodont faunas from the eastern Mendips, England: Palaeontology, v. 16, pt. 3, p. $477-517$, pls. $56-59,12$ figs.

Carr, W. J., and Trimble, D. E., 1961, Upper Paleozoic rocks in the Deep Creek Mountains, Idaho: U.S. Geol. Survey Prof. Paper 424-C, p. C181-C184, fig. 213.1.

Cheney, T. M., 1957, Phosphate in Utah and an analysis of the stratigraphy of the Park City and Phosphoria Formations, Utah-A preliminary report: Utah Geol. Mineralog. Survey Bull. 59, 54 .p., 12 figs., 3 pls.

Collinson, Charles, Scott, A. J., and Rexroad, C. B., 1962, Six charts showing biostratigraphic zones and correlations based on conodonts from the Devonian and Mississippian rocks of the Upper Mississippi Valley: Illinois State Geol. Survey Circ. 328, 32 p., 6 charts.

Dutro, J. T., Jr., and Sando, W. J., 1963, New Mississippian formations and faunal zones in Chesterfield Range, Portneuf quadrangle, southeast Idaho: Am. Assoc. Petroleum Geologists Bull., v. 47, no. 11, p. 1963-1986, 6 figs.

Jenkins, T. B. H., 1974, Lower Carboniferous conodont biostratigraphy of New South Wales: Palaeontology, v. 17, pt. 4, p. 909-924, pl. 119.

Mamet, B. L., Skipp, Betty, Sando, W. J., and Mapel, W. J., 1971, Biostratigraphy of Upper Mississippian and associated Carboniferous rocks in south-central Idaho: Am. Assoc. Petroleum Geologists Bull., v. 55, no. 1, p. 20-33, 3 figs.

Matthews, S. C., 1971, Comments on palaeontological standards for the Dinantian: Cong. Internat. Stratigraphie Géologie Carbonifère, 6th, Sheffield, 1967, Compte rendu, v. 3, p. 1159-1164,
Maughan, E. K., 1963, Mississippian rocks in the Laramie Range, Wyoming, and adjacent areas: U.S. Geol. Survey Prof. Paper 475-C, p. C23-C27.

Mudge, M. R., Sando, W. J., and Dutro, J. T., Jr., 1962, Mississippian rocks of Sun River Canyon area, Sawtooth Range, Montana: Am. Assoc. Petroleum Geologists Bull., v. 46, no. 11, p. 2003-2018, 6 figs.

Paull, R. A., Wolbrink, M. A., Volkmann, R. G., and Grover, R. L., 1972, Stratigraphy of Copper Basin Group, Pioneer Mountains, south-central Idaho: Am. Assoc. Petroleum Geologists Bull., v. 56, no. 18, p. 1370-1401, 21 figs.

Petersen, M. S., 1969, The occurrence of ammonoids from the lower Deseret Limestone, northern Stansbury Mountains, Tooele County, Utah [abs.]: Geol. Soc. America Abs. with Programs 1969, [v. 1], pt. 5, p. 63.

Poole, F. G., 1974, Flysch deposits of the Antler Foreland basin, western United States, in Dickinson, W. R. (ed.), Tectonics and sedimentation: Soc. Econ. Paleontologists and Mineralogists Spec. Pub. 22, p. 58-82.

Rexroad, C. B., and Scott, A. J., 1964, Conodont zones in the Rockford Limestone and in the lower part of the New Providence Shale (Mississippian) in Indiana: Indiana Geol. Survey Bull. 30, 54 p., 3 pls.

Rose, P. R. 1976, Mississippian carbonate shelf margins, Western United States: U.S. Geol. Survey Jour. Research, v. 4, no. 4 p. 449-466.

Sandberg, C. A., 1975, McGowan Creek Formation, new name for Lower Mississippian flysch sequence in east-central Idaho: U.S. Geol. Survey Bull. 1405-E, 11 p., 1 fig.

Sandberg, C. A., and Mapel, W. J., 1967, Devonian of the northern Rocky Mountains and plains, in Oswald, D. H., ed., Internat. Symposium on the Devonian System, Calgary, Alberta, Sept. 1967, [Proc.], v. 1: Calgary, Alberta Soc. Petroleum Geologists, p. 843-877, 10 figs. [1968].

Sando, W. J., 1960, Corals from well cores of Madison Group, Williston basin: U.S. Geol. Survey Bull. 1071-F, p. 157190 , pls. $13-20$, figs. 16,17 [1961].

1967a, Madison Limestone (Mississippian), Wind River, Washakie, and Owl Creek Mountains, Wyoming: Am. Assoc. Petroleum Geologists Bull., v. 51, no. 4, p. 529557, 8 figs.

1967b, Mississippian depositional provinces in the northern Cordilleran region: U.S. Geol. Survey Prof. Paper 575-D, p. D29-D38, 3 figs.

- 1975, Diastem factor in Mississippian rocks of the northern Rocky Mountains: Geology, v. 3, no. 11, p. 657660,5 figs.

1976, Mississippian history of the northern Rocky Mountains region: U.S. Geol. Survey Jour. Research, v. 4 , no. 3 , p. $317-338$.

Sando, W. J., and Dutro, J. T., Jr., 1960, Stratigraphy and coral zonation of the Madison Group and Brazer Dolomite in northeastern Utah, western Wyoming, and southwestern Montana: Wyoming Geol. Assoc. 15th Ann. Field Conf., 1960, Guidebook, p. 117-126, 1 pl., 3 figs.

Sando, W. J., Dutro, J. T., Jr., and Gere, W. C., 1959, Brazer Dolomite (Mississippian), Randolph quadrangle, northeast Utah: Am. Assoc. Petroleum Geologists Bull., v. 43, no. 12 , p. 2741-2769, 5 figs.

Sando, W. J., Gordon, Mackenzie, Jr., and Dutro, J. T., Jr., 1975, Stratigraphy and geologic history of the Amsden Formation (Mississippian and Pennsylvanian) of Wyoming: U.S. Geol. Survey Prof. Paper 848-A, 78 p., 9 pls., 22 figs. 
Sando, W. J., and Mamet, B. L., 1974, New evidence on the age of the top of the Madison Limestone, Bighorn Mountains, Wyoming and Montana: U.S. Geol. Survey Jour. Research, v. 2, no. 5, p. 619-624, 4 figs.

Sando, W. J., Mamet, B. L., and Dutro, J. T., Jr., 1969, Carboniferous megafaunal and microfaunal zonation in the northern Cordillera of the United States: U.S. Geol. Survey Prof. Paper 613-E, 29 p., 7 figs.
Skipp, Betty, and Mamet, B. L., 1970, Stratigraphic micropaleontology of the type locality of the White Knob Limestone (Mississippian), Custer County, Idaho: U.S. Geol. Survey Prof. Paper 700-B, p. B118-B123.

Thompson, T. L., 1967, Conodont zonation of lower Osagean rocks (Lower Mississippian) of southwestern Missouri: Missouri Div. Geol. Survey and Water Resources Rept. Inv. 39, 88 p., 6 pls., 6 flgs. 


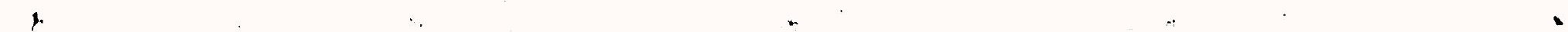




\title{
SIMULATION OF FOREST CHANGES RELATED TO HYDROLOGIC VARIABLES IN THE ATCHAFALAYA RIVER BASIN, LOUISIANA
}

\author{
By M. E. JENNINGS and C. P. O'NEIL, Bay Saint Louis, Miss. \\ Work done in cooperation with the U.S. Fish and Wildlife Service
}

\begin{abstract}
Results of forest-trend modeling from one data set in the Atchafalaya River basin show that predicted forest acreage totals for 16 forest types agree within 30 percent of actual values in two-thirds of the comparisons. A forest-trend simulation model based on statistical regression relations of forest and hydrologic variables and constrained by forest succession concepts was developed using observed data from twenty-four 8-square-mile (20.74-square-kilometre) quadrats. Forest and hydrologic data at each quadrat were sampled in time at three 4-mile (6.44-kilometre)-wide strips across the basin. The model predicts changes in forest-type acreages due to hydrologic change in time steps, or forest acreage transition, of 21 years. Further basin-wide quadrat simulations are planned using hydrologic input data from a flow-sediment model of the basin currently being developed. Other ecosystem models could be appended to the forest-trend simulation model.
\end{abstract}

The Atchafalaya River basin occupies approximately 1,800 square miles $(466,200 \mathrm{ha})$ of low land in southcentral Louisiana, consisting mostly of swamps, lakes, streams, and forest. For several hundred years, the basin has been a distributary of the Mississippi River, acting as a natural floodway to divert excess water away from the Mississippi. In recent decades, a system of water-control structures, including levees bordering most of the basin, has been constructed for flood control purposes. Up to half of the flow of the Mississippi can now be routed through the Atchafalaya basin. In addition to high streamflows, the basin also experiences very heavy sediment loads with an estimated $80,000,000$ cubic yards $\left(61,200,000 \mathrm{~m}^{3}\right)$ of sediment being deposited within the basin annually.

The Atchafalaya basin land and water management study, a joint effort of the U.S. Department of Interior and the U.S. Army Corps of Engineers, is currently underway to determine an optimum use of the resources of the basin as a floodway and as a balanced ecosystem. The objective of the study reported herein is to develop a forest-trend simulation model based on predictive relations between changes in areal extent of selected forest types and several hydrologic variables.
A predictive model of this kind is believed to have significant potential use in studying changes in forest trends likely to occur due to anticipated hydrologic change. Hydrologic change due to various alternative basin management plans is a key factor in forest-trend studies of the Atchafalaya River basin.

Acknowledgments. - The writers acknowledge the encouragement of G. M. Gardner, Office of Assistant Secretary of Interior for Fish and Wildlife and Parks in the preparation of this report.

\section{FOREST ACREAGE TREND MODELING}

Several recent studies have focused on the problem of forest simulation. The work of Botkin and Miller (1974), using conceptually based algorithms relating forest growth to approximately 10 environmental factors, resulted in the development of a northeastern forest-growth simulator. A similar study on simulation of southern wetland forests using a plot of 0.1 acre $(0.04$ ha) is underway by R. L. Phipps (written commun., 1974).

Because of the large and diverse nature of the Atchafalaya basin and the need to consider all or most of the basin, detailed investigations of the above kind could not be undertaken in this study. Instead, an empirical model based on statistical methods and forestry concepts using observed forest acreage and available hydrologic data was selected.

The model predicts forest acreage transitions (approx 21-year acreage changes) on a quadrat basis using data from 24 quadrats. A forest acreage transition is defined as a discrete change in acreage of a given forest type during a time period of 21 years. The quadrat size of $8 \mathrm{mi}^{2}\left(20.74 \mathrm{~km}^{2}\right)$ is an arbitrary choice representing a balance between expected accuracy of the model and data definition capability. The objective of the analysis is not to simulate vegetation change by use of all factors correlated with vegetation distribution, but to determine how accurately factors associated with hy- 
drologic change can predict vegetation change. In future simulation studies, approximately 150 quadrats will be used to simulate forest trends under alternative basin management plans.

\section{DATA USED IN THE STUDY}

The data base for the statistical model includes 4 basic hydrologic variables and 16 forest types and related variables. Figure 1 is a map of the Atchafalaya

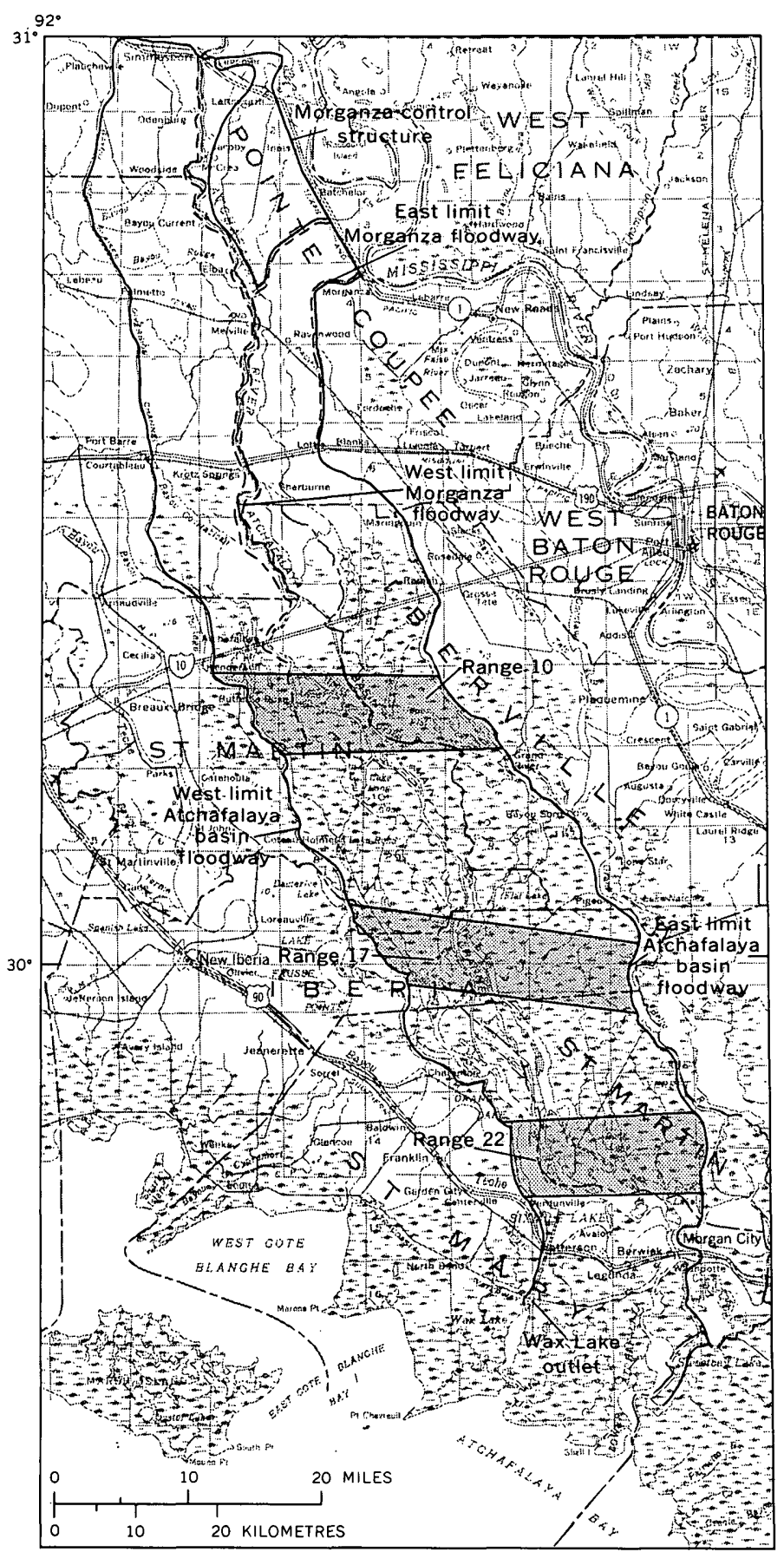

Figure 1.-Study area, Atchafalaya River basin, Louisiana. See text for explanation of ranges and shaded areas. basin study area and shows the location of test strips on which vegetation acreages were sampled. The test strips (shown shaded) are $4 \mathrm{mi}(6.44 \mathrm{~km})$ wide and span the basin from west to east guide levees. Three sets of aerial photographs for years 1930, 1952, and 1973 were available for each test strip. The test strips are associated with Corps of Engineers' sedimentation range lines 10,17, and 22 , along which hydrologic information is available for approximately the same times as that of the available aerial photographs.

The test strips were subdivided into 26 quadrats, each $2 \mathrm{mi}(3.22 \mathrm{~km})$ by $4 \mathrm{mi}(6.44 \mathrm{~km})$, except for quadrats near levees which contain less than $8 \mathrm{mi}^{2}\left(20.74 \mathrm{~km}^{2}\right)$. Hydrologic data were available for 24 of the 26 quadrats. Thus, observed data from 24 quadrats, or environmental sampling units, were available for analysis.

\section{Forest-acreage data}

Forest types are defined, for the purpose of this study, as vegetation units composed of one or more forest species distinguishable on aerial photographs. The forest types are listed in table 1. Forest-type data for each quadrat were identified and obtained from aerial photography by planimetry. The sets of aerial photographs acquired from the National Aeronautics and Space Administration and the Corps of Engineers varied in scale from $1: 120,000$ to $1: 20,000$ and included panchromatic, black and white infrared, and color infrared photographs (C. P. O'Neil, J. E. deSteiguer, and G. W. North, unpub. data, 1975).

Field investigations were undertaken to obtain a key for use in identifying each forest type on the aerial photographs. Both beginning and ending acreages for each type representing a forest transition were tabulated. Table 2 is a matrix of observed forest type data for the 16 types to be predicted by the forest-trend simulation model.

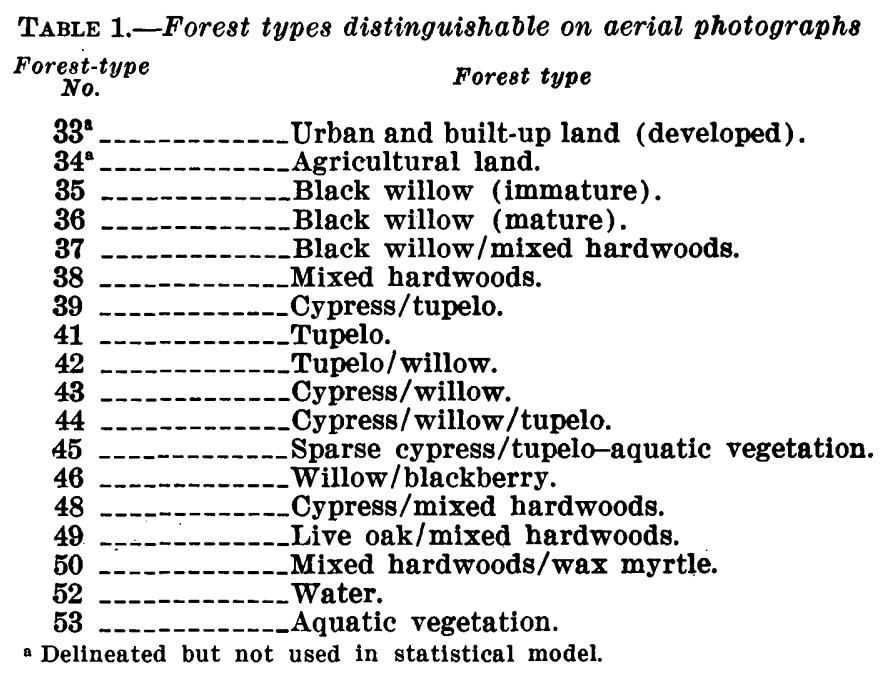


TABLE 2.-Observed forest-type data for years 1930, 1952, and 1973 for all quadrats, in acres times 1,000

[See table 1 for explanation of forest-type numbers]

\begin{tabular}{|c|c|c|c|c|c|c|c|c|c|c|c|c|c|c|c|c|c|}
\hline \multirow{2}{*}{ Year } & \multirow{2}{*}{ Quadrat } & \multicolumn{16}{|c|}{ Forest-type No. } \\
\hline & & 35 & 36 & 37 & 38 & 39 & 41 & 42 & 43 & 44 & 45 & 46 & 48 & 49 & 50 & 52 & 53 \\
\hline 1930 & R10-1 & 0.941 & 0.058 & 0,371 & 0.006 & 0.0 & 0.0 & 0.058 & 0.256 & 0.429 & 1.126 & 0.0 & 0.0 & 0.0 & 0.307 & 0.806 & 0.346 \\
\hline 1952 & & .250 & 1.606 & .582 & .832 & .0 & .0 & $\begin{array}{l}.000 \\
.192\end{array}$ & $\begin{array}{r}.109 \\
\end{array}$ & .0 & .0 & .0 & .0 & .0 & .365 & .141 & .205 \\
\hline 1930 & R10-2 & .845 & .058 & .909 & .563 & .0 & .0 & .0 & .275 & .256 & .608 & .0 & .0 & .0 & 1.120 & .384 & .006 \\
\hline 1952 & & .211 & .723 & .742 & 1.427 & .0 & .0 & .154 & .147 & .0 & 10 & .0 & .0 & .0 & 1.437 & .531 & .045 \\
\hline 1973 & & .186 & .570 & 1.050 & 1.824 & .0 & .0 & .096 & .0 & .0 & .0 & .0 & .0 & .0 & .480 & .634 & .109 \\
\hline 1930 & R10-3 & .282 & .0 & .621 & .576 & .026 & .0 & .173 & .0 & 1.280 & .442 & .0 & .0 & .0 & .902 & .467 & .275 \\
\hline 1952 & & .038 & .378 & .147 & .877 & .0 & .013 & .0 & .0 & .0 & 1,146 & .0 & .0 & .0 & 1.312 & .742 & .474 \\
\hline 1973 & & .742 & .237 & .371 & 1.907 & .0 & .0 & .0 & .0 & .0 & 186 & .0 & .0 & .0 & .422 & 1.030 & .058 \\
\hline 1930 & R10-4 & .243 & .115 & .646 & .422 & .0 & .0 & .198 & .013 & .749 & .550 & .0 & .0 & .032 & .0 & 1.453 & .602 \\
\hline 1952 & & .730 & .384 & .038 & 1.011 & .0 & .013 & .032 & .141 & .0 & .173 & .0 & .0 & .0 & 1.350 & .710 & .538 \\
\hline 1973 & & .205 & .531 & .640 & 1.344 & .0 & .0 & .0 & .0 & .0 & .045 & .0 & .0 & .0 & .544 & .838 & .179 \\
\hline 1930 & R10-5 & .941 & .333 & .435 & .141 & .0 & .045 & .064 & 1.485 & .006 & .461 & .0 & .0 & .019 & .0 & 1.069 & .070 \\
\hline 1952 & & .038 & .365 & .0 & 1.312 & .0 & .013 & .083 & 1.882 & .0 & .0 & .0 & .0 & .0 & .525 & .909 & .0 \\
\hline 1973 & & .026 & .320 & .045 & 1.389 & .0 & .0 & .0 & .787 & .0 & .0 & .0 & .0 & .0 & 1.562 & .826 & .109 \\
\hline 1930 & R10-6 & .013 & .0 & .0 & .0 & .0 & .0 & .0 & .0 & .0 & .0 & .0 & .0 & .0 & .0 & 1.171 & .032 \\
\hline 1952 & & .0 & .0 & .0 & .013 & .0 & .134 & .0 & 2.656 & 1.165 & .0 & .0 & .0 & .0 & .0 & .454 & .0 \\
\hline 1973 & & .147 & .544 & .0 & .013 & .0 & .218 & .0 & 3.040 & .493 & .0 & .0 & .032 & .0 & .192 & .134 & .0 \\
\hline 1930 & R10-7 & .0 & .0 & .0 & .0 & .0 & .0 & .0 & .0 & .0 & 2.246 & .0 & .0 & .0 & .0 & 1.222 & .0 \\
\hline 1952 & & .0 & .109 & .0 & .0 & .0 & .096 & .0 & $\mathbf{2 . 3 4 9}$ & 1.645 & .0 & .0 & .0 & .0 & .0 & .922 & .0 \\
\hline 1973 & & .026 & .954 & .0 & .0 & .0 & .045 & .0 & 1.754 & 1.581 & .0 & .122 & .288 & .0 & .0 & .224 & .096 \\
\hline 1930 & R10-8 & .0 & .0 & .0 & .0 & .0 & .0 & .0 & .0 & .0 & 1.811 & .0 & .0 & .0 & .0 & .806 & .0 \\
\hline 1952 & & .0 & .0 & .0 & .0 & .0 & .0 & .0 & .0 & .416 & .0 & .0 & .0 & .0 & .0 & 1.158 & .0 \\
\hline 1973 & & .026 & .390 & .0 & .0 & .0 & .0 & .0 & .0 & .070 & .0 & .0 & .141 & .0 & .0 & .410 & .128 \\
\hline 1930 & R17-3 & 2.093 & .0 & .0 & .0 & .710 & .0 & .0 & .0 & .230 & .371 & .0 & .0 & .0 & .0 & 1.203 & .512 \\
\hline 1952 & & .550 & 2.918 & .0 & .0 & .0 & .0 & .0 & .019 & .0 & .243 & .0 & .0 & .0 & .0 & 1.267 & .128 \\
\hline 1973 & & .384 & 1.670 & .819 & .288 & .0 & .077 & .0 & .0 & .0 & .0 & .0 & .0 & .026 & .710 & 1.069 & .051 \\
\hline 1930 & R17-4 & .781 & .0 & .0 & .0 & .0 & .0 & .0 & .0 & 1.920 & .416 & .0 & .0 & .0 & .0 & 1.805 & .205 \\
\hline 1.952 & & .512 & 1.325 & .013 & .0 & .0 & .090 & .0 & .0 & 1.376 & .634 & .0 & .0 & .0 & .0 & 1.146 & .026 \\
\hline 1973 & & .077 & .378 & .461 & .614 & .0 & .131 & .0 & .218 & 1.504 & .0 & .0 & .358 & .0 & .397 & .736 & .032 \\
\hline 1930 & R17-5 & .0 & .0 & .0 & .0 & 2.995 & .038 & .0 & .0 & 1.638 & .083 & .0 & .0 & .0 & .0 & .352 & .013 \\
\hline 1952 & & .083 & .0 & .0 & .0 & 2.771 & .0 & .0 & .0 & 1.805 & .0 & .0 & .0 & .0 & .0 & .461 & .0 \\
\hline 1973 & & .0 & .0 & .090 & .032 & .0 & .083 & .0 & .0 & 4.160 & .0 & .0 & .122 & .0 & .045 & .563 & .026 \\
\hline 1930 & R17-6 & .0 & .0 & .0 & .0 & 3.130 & .102 & .0 & .0 & .589 & 1.152 & .0 & .0 & .0 & .0 & .141 & .0 \\
\hline 1952 & & .147 & .147 & .0 & .0 & 3.968 & .109 & .0 & .0 & .493 & .0 & .0 & .0 & .0 & .0 & .243 & .006 \\
\hline 1973 & & .0 & .0 & .0 & .0 & .0 & .0 & .0 & .0 & 3.750 & .0 & .0 & .646 & .0 & .032 & .672 & .0 \\
\hline 1930 & R17-7 & .0 & .0 & .0 & .0 & 4.282 & .0 & .0 & .0 & .422 & .147 & .0 & .0 & .0 & .0 & .275 & .0 \\
\hline 1952 & & .0 & .0 & .0 & .0 & 4.397 & .0 & .0 & .0 & .294 & .0 & .0 & .0 & .0 & .0 & .397 & .032 \\
\hline 1973 & & .0 & .0 & .0 & .0 & .0 & .0 & .0 & .0 & 3.674 & .0 & .0 & .774 & .0 & .0 & .646 & .026 \\
\hline 1930 & R17-8 & .0 & .0 & .0 & .0 & $3.3^{41}$ & 1.197 & .0 & .0 & .0 & .0 & .0 & .0 & .0 & .0 & .230 & .0 \\
\hline 1952 & & .0 & .0 & .0 & .0 & 2.675 & .762 & .0 & .0 & .0 & .0 & .0 & .0 & .0 & .0 & .154 & .038 \\
\hline 1973 & & .0 & .0 & .0 & .0 & .0 & .538 & .0 & .0 & 2.317 & .0 & .0 & .627 & .0 & .0 & .422 & .0 \\
\hline 1930 & R17-9 & .0 & .0 & .0 & .0 & 3.686 & $1.1^{\Delta 6}$ & .0 & .0 & .0 & .0 & .0 & .0 & .0 & .0 & .262 & .026 \\
\hline 1952 & & .0 & .0 & .0 & .0 & 2.121 & 1.555 & .0 & .0 & .774 & .154 & .0 & .147 & .0 & .0 & .230 & .134 \\
\hline 1973 & & .0 & .0 & .0 & .0 & .0 & 1.754 & .0 & .0 & 2.598 & .0 & .0 & .269 & .0 & .0 & .493 & .0 \\
\hline 1930 & R17-10 & .0 & .0 & .0 & .0 & 4.448 & .320 & .0 & .0 & .0 & .0 & .0 & .0 & .0 & .0 & .352 & .0 \\
\hline $19 \kappa 2$ & & .0 & .0 & .0 & .0 & 1.869 & .301 & .0 & .0 & 2.093 & .0 & .0 & .26 & .0 & .0 & .563 & .026 \\
\hline 1973 & & .0 & .0 & .0 & .0 & .0 & .467 & .0 & .0 & 3.462 & .0 & .0 & .282 & .0 & .0 & .902 & .0 \\
\hline $19 \kappa 2$ & R22-1 & .0 & .0 & .0 & .0 & .717 & .0 & .0 & .0 & .0 & .0 & .0 & .0 & .013 & .0 & 4.141 & .006 \\
\hline 1973 & & 1.363 & .0 & .0 & .0 & .653 & .0 & .0 & .0 & .0 & .0 & .147 & .058 & .058 & .0 & 2.432 & .0 \\
\hline 1952 & R22-2 & .659 & .0 & .0 & .0 & 1.299 & .0 & .0 & .0 & .0 & .0 & .0 & .0 & .474 & .0 & 2.688 & .0 \\
\hline 1973 & & 1.651 & .122 & .051 & .0 & 1.382 & .0 & .0 & .0 & .0 & .0 & .320 & .0 & .422 & .013 & 1.139 & .013 \\
\hline 1952 & R22-3 & .147 & .0 & .0 & .0 & 2.746 & .0 & .0 & .0 & .0 & .051 & .0 & .0 & .320 & .0 & 1.786 & .051 \\
\hline 1973 & & .442 & .0 & .0 & .0 & 2.707 & .0 & .0 & .0 & .0 & .0 & .0 & .0 & .448 & .0 & 1.517 & .0 \\
\hline $19 \Omega 2$ & R22-4 & .083 & .0 & .0 & .0 & 2.393 & .621 & .0 & .0 & .0 & .0 & .01 & .0 & .0 & .0 & 1.754 & .326 \\
\hline 1973 & & .256 & .0 & .0 & .0 & $2.5 \Delta 7$ & .525 & .0 & .0 & .0 & .0 & .064 & .0 & .019 & .0 & 1.619 & .090 \\
\hline $19 \kappa 2$ & R22-5 & .0 & .0 & .0 & .0 & 3.910 & .134 & .0 & .0 & .0 & .0 & .0 & .0 & .0 & .0 & .960 & .115 \\
\hline 1973 & & .0 & .0 & .0 & .0 & 4.051 & .147 & .0 & .0 & .0 & .0 & .0 & .0 & .0 & .0 & .864 & .058 \\
\hline 1952 & R22-6 & .0 & .0 & .0 & .0 & $\mathbf{3 . 0 5 9}$ & 1.133 & .0 & .0 & .0 & .0 & .0 & .09 & .0 & .0 & .832 & .0 \\
\hline 1973 & & .0 & .0 & .0 & .0 & 3.002 & 1.325 & .0 & .0 & .0 & .0 & .0 & .128 & .0 & .0 & .668 & .0 \\
\hline 1952 & R22-7 & .0 & .0 & .0 & .0 & 1.843 & 2.317 & .0 & .0 & .0 & .0 & .0 & .058 & .006 & .0 & .826 & .0 \\
\hline 1973 & & 0 & 0 & 0 & .0 & 1.978 & 2.451 & .0 & .0 & .0 & .0 & .0 & .096 & .019 & .0 & .570 & .0 \\
\hline 1952 & R22-8 & .0 & .0 & .0 & .0 & .0 & .960 & .0 & .0 & .0 & .0 & .0 & .083 & .0 & .0 & .704 & .0 \\
\hline 1973 & & .0 & .0 & .0 & .0 & .0 & .736 & .0 & .0 & .0 & .0 & .0 & .0 & .096 & .0 & .653 & .0 \\
\hline
\end{tabular}

\section{Hydrologic data}

Hydrologic variables used in the statistical calculations are defined and listed in table 3 . The set of hydrologic variables represents those quantities which will undergo change as the result of proposed alternative water-management plans for the basin. Thus, while other environmental factors undoubtedly affect vegetation change, the marginal vegetative change due to 
TABLE 3.-Hydrologic variables used in study

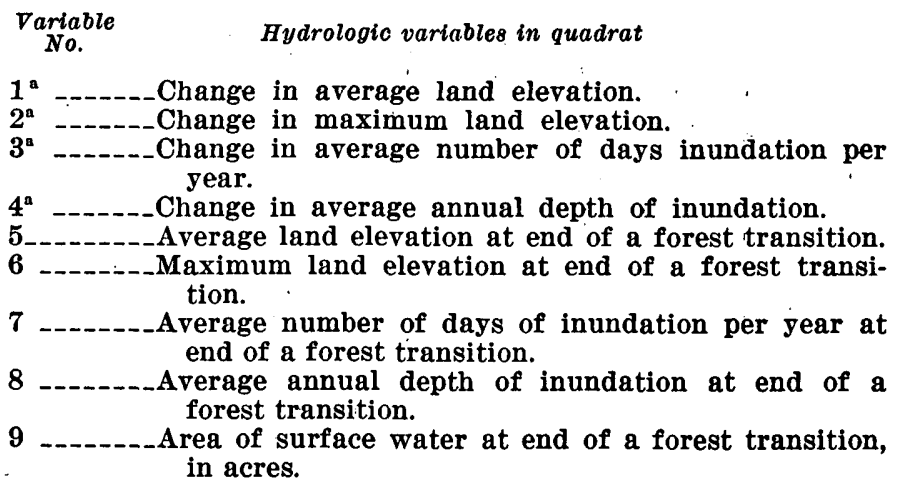

" Change in hydrologic variables corresponds as closely as possible to $1930-52$ or $1952-73$ forest transition periods.

hydrologic change (either natural or manmade) is of primary interest in these studies.

As previously mentioned, hydrologic data are available at ranges 10,17 , and 22 . Using data from the U.S. Army Corps of Engineers publications (1930-1964, 1965-1969), including sedimentation-range and riverstage data, the following four hydrologic quantities were obtained for each quadrat: (a) Average land elevation as determined along applicable range line, (b) maximum land elevation as determined along applicable range line, (c) average number of days per year quadrat was inundated, and (d) average annual depth of inundation in quadrat. Several utility computer programs were used to process and prepare the crosssection (available from sedimentation range plots) and river-stage (available from published records at nearby gaging stations) data. The first variable was obtained by averaging interpolated ground elevations (mean sea level) at 100 -feet $(30.48-\mathrm{m})$ intervals across the 2-mi $(3.22-\mathrm{km})$ quadrat widths. The second variable was the highest ground elevation (msl) in the 2$\mathrm{mi}(3.22-\mathrm{km})$ quadrat width along the range line. The third variable was obtained by comparing average quadrat land elevation with annual river-stage hydrographs from a nearby gaging station. The number of days within the year in which river stage exceeded average land elevation was tabulated. Five determinations using annual hydrographs for years near 1930, 1952 , and 1973 were then averaged to define the variable. The fourth variable is the corresponding average annual depth determined as river stage minus average land elevation.

The four basic hydrologic variables were then used to create four additional variables based on difference between ending and beginning values which represent hydrologic change during a forest transition. A ninth hydrologic variable, obtained by planimetry, was the acreage of surface water present in each quadrat.

\section{STATISTICAL ANALYSES}

The statistical component of the forest-trend simulation model is linear regression analysis using stepwise multiple linear regression methods. Only one set of forest-type data was available for use in the study.

Recalling the strip-quadrat system as shown in figure 1 , let $Y(i, j, k, t)$ denote the number of acres occupied by the $i$ th forest type in the $j$ th quadrat of the $k$ th strip in year $t$. Let $X(l, j, k, t)$ denotes the value of the $l$ th basic hydrologic variable in the $j$ th quadrat of the $k$ th strip in year t. Hydrologic change variables are created by setting

$$
\Delta X(l, j, k, t)=X(l, j, k, t)-X(l, j, k, t-1) .
$$

Thus, a regression equation for estimates $\hat{Y}(i, j, k, t)$ can be written for each $i=1,2, \ldots 16$,

$$
\begin{aligned}
\hat{Y}(i, j, k, t)= & \beta(0, i)+\sum_{l=1}^{5} \beta(l, i) X(l, j, k, \mathrm{t}) \\
& \pm \sum_{l=1}^{4} \gamma(l, i) \Delta X(l, j, k, t) \\
& +\delta(i) Y(i, j, k, t-1)
\end{aligned}
$$

for all values of $j, k, t$ for which data are available. The last term in equation 1 represents an autoregressive component.

Because of the nature of hydrologic and forest-type data, data vectors used in the final regression equations will not be independent in time or space. This fact will limit the validity of statistical reliability tests. The coefficients $\beta, \gamma$, and $\delta$, as well as the standard error of estimate, are determined as a result of the regression computation.

A feature of the regression problem is the constraint that $\Sigma \hat{Y}(i, j, k, t)$ for $i=1,2, \ldots 16$ for each $j$ th quadrat must equal $8 \mathrm{mi}^{2}\left(20.74 \mathrm{~km}^{2}\right)$. Because no restrictions are placed on the regression procedure, it may be that some $\hat{Y}(i, j, k, t)$ 's may exceed $8 \mathrm{mi}^{2} \quad(20.74$ $\left.\mathrm{km}^{2}\right)$. While an approach based on multivariate statistical processes may offer a solution to the problem, an interim empirical approach was selected. The approach uses individual regression analysis based on equation 1 and forest-category type constraints based on relations between forest types as distinguished on aerial photographs.

A computer program, BMD02R, of the University of California, (1968) was used to perform the analyses. The program computes a sequence of multiple linear regression equations in a stepwise manner. At each step, one variable is added to the regression equation. The variable added is the one which makes the great- 
est reduction in the error sum of squares. Equivalently it is the variable which, if it were added, would have the highest $F$-value. The use of the $F$-value in this analysis is limited to that of a control variable for entry and exit of independent variables. The program allows variables to be forced into the equation, and also, will automatically remove nonforced variables when their $F$-values become too low. $F$-values for inclusion of variables were set at $0.01 ; F$-values for variable deletion were set at 0.005 . In addition the program contains a feature for forcing the regression intercept through the origin and for fixed regressions both of which were utilized in the computer runs.

Several regression runs were made using the model of equation 1 with and without the autoregressive component. These included (a) log transformation of variables, (b) individual regressions for each strip, (c) regressions using riverine and backswamp quadrats separately, and (d) the basic untransformed model with the autoregressive component. Log transformation of dependent and independent variables offered no improvement in standard error of estimate, the parameter used to measure accuracy. Individual strip regressions were unsatisfactory because of a small number of data items and consequent loss of statistical significance. Regressions using data sorted into data from quadrats in predominately riverine and predominately backswamp areas yielded no substantial improvement in results. Therefore, final regression results were based on combined data from all strips using the model of equation 1 including an autoregressive component. The autoregressive component is simply the last forest-type acreage for the type being predicted which is included as an additional independent variable.

The first phase of regression runs was made using the stepwise option in an effort to find the most important independent variables. Four of the nine inde- pendent hydrologic variables were identified as explaining most of the variance when the set of forestacreage prediction equations was compared. These were (a) change in maximum land elevation in quadrat, (b) change in average number of days inundation per year in quadrat, (c) average land elevation in quadrat at end of a forest transition, and (d) last acreage of forest-type variable. Therefore, the final phase of regression runs used these four variables without the stepwise option.

Regression results using each of the 16 forest-type variables regressed against these four variables are given in table 4 . The order of significance of each independent variable is also shown in table 4.

Within the subset of four independent variables, the most significant were generally last acreage and average land elevation at the end of a forest transition period. This fact suggests the dominant effect on forest type change of sedimentation superimposed on a natural forest succession.

The standard error of estimate in units of acres varied from \pm 49.3 acres $(20.0 \mathrm{ha})$ for forest-type variable 49 to $\pm 1,154.2$ acres ( $467 \mathrm{ha}$ ) for forest-type variable 44 . In general, forest-type variables which experienced least erratic transitions were best predicted. All equations included one or more transitions to or from a zero acreage, and most equations appeared capable of computing this situation.

\section{FOREST-TREND SIMULATION}

The regression relations alone are not adequate for long-term forest-trend predictions. For example, they include no interrelationships among forest types. Also due to significant error potential, depending on the equation, they are capable of negative or unreasonably large acreage predictions. Because the forest-trend sim-

Table 4.-Summary of regression results

[Number in parenthesis is rank of significance of independent variables]

\begin{tabular}{|c|c|c|c|c|c|c|c|c|c|c|}
\hline \multirow{2}{*}{$\begin{array}{c}\text { Forest- } \\
\text { type } \\
\text { No.a }\end{array}$} & \multirow[b]{2}{*}{$\begin{array}{c}\text { Multiple } \\
\text { correlation } \\
\text { coefficient }\end{array}$} & \multirow[b]{2}{*}{$\begin{array}{c}\text { Standard error } \\
\text { of estimate, acres } \\
\text { times } 1,000\end{array}$} & \multicolumn{8}{|c|}{ Regression constants of independent variables } \\
\hline & & & \multicolumn{2}{|c|}{ No. $2^{b}$} & \multicolumn{2}{|c|}{ No. $3^{\mathrm{b}}$} & \multicolumn{2}{|c|}{ No. $5^{b}$} & \multicolumn{2}{|c|}{$\begin{array}{c}\text { Last } \\
\text { acreage } \\
\text { (forest type) }\end{array}$} \\
\hline $\begin{array}{l}35 \\
36 \\
37 \\
38 \\
39 \\
41 \\
42 \\
43 \\
44 \\
45 \\
46 \\
48 \\
49 \\
50 \\
52 \\
53\end{array}$ & $\begin{array}{r}0.6129 \\
.7197 \\
.9103 \\
.9554 \\
.8908 \\
.9793 \\
.8285 \\
.8593 \\
.7710 \\
.4969 \\
.7111 \\
.7547 \\
.9590 \\
.7621 \\
.9409 \\
.8023\end{array}$ & $\begin{array}{r}0.3777 \\
.7318 \\
.2965 \\
.3418 \\
1,0604 \\
.1528 \\
.0591 \\
.7787 \\
1.1542 \\
.2509 \\
.1880 \\
.2039 \\
.0493 \\
.4208 \\
.3114 \\
.0881\end{array}$ & $\begin{array}{r}-0.00262 \\
.05612 \\
-.03413 \\
-.01588 \\
-.02105 \\
-.00555 \\
.00168 \\
-.00849 \\
.02695 \\
.00221 \\
.03739 \\
-.00666 \\
-.00069 \\
-.01597 \\
.01427 \\
-.00072\end{array}$ & $\begin{array}{l}(4) \\
(3) \\
(2) \\
(3) \\
(4) \\
(2) \\
(4) \\
(2) \\
(4) \\
(3) \\
(1) \\
(3) \\
(3) \\
(2) \\
(3) \\
(4)\end{array}$ & $\begin{array}{r}-0.00105 \\
.00112 \\
-.00050 \\
.00029 \\
.01728 \\
-.00015 \\
.00024 \\
-.00065 \\
-.00823 \\
.00102 \\
.00152 \\
-.00246 \\
.00007 \\
.00069 \\
-.00075 \\
.00031\end{array}$ & $\begin{array}{l}(2) \\
(4) \\
(4) \\
(4) \\
(2) \\
(4) \\
(2) \\
(2) \\
(2) \\
(2) \\
(4) \\
(1) \\
(2) \\
(3) \\
(4) \\
(3)\end{array}$ & $\begin{array}{r}0.00282 \\
.01776 \\
.02969 \\
.05433 \\
.29166 \\
.00241 \\
.00583 \\
-.00640 \\
-.03324 \\
.01390 \\
-.00520 \\
.00655 \\
.00000 \\
.05032 \\
.00907 \\
.00628\end{array}$ & $\begin{array}{l}(3) \\
(1) \\
(1) \\
(1) \\
(3) \\
(3) \\
(1) \\
(3) \\
(3) \\
(1) \\
(2) \\
(4) \\
(4) \\
(1) \\
(2) \\
(2)\end{array}$ & $\begin{array}{r}0.37988 \\
.64372 \\
.19567 \\
.67032 \\
.57012 \\
1.02520 \\
-.25087 \\
.80852 \\
.96858 \\
-.01367 \\
-8.93693 \\
.57042 \\
1.05780 \\
.00000 \\
.60320 \\
.39050\end{array}$ & $\begin{array}{l}(1) \\
(2) \\
(3) \\
(2) \\
(1) \\
(1) \\
(3) \\
(1) \\
(1) \\
(4) \\
(3) \\
(2) \\
(1) \\
(4) \\
(1) \\
(1)\end{array}$ \\
\hline
\end{tabular}

a Refer to table 1 for explanation of forest-type numbers.
b Refer to table 3 for explanation of hydrologic variable numbers. 
ulation model is likely to be used for predictions of up to five forest transitions (over $100 \mathrm{yr}$ ), a study of forest succession for the Atchafalaya basin, in the light of observed behavior as shown in table 2 , is necesary.

As sedimentation occurred within a test strip where there was land accretion within streams and lakes, a natural and predictable succession of vegetation could be observed by study of the sequential aerial photographs. These trends are depicted in figure 2, a flow chart of forest succession for the Atchafalaya River basin.

Two climax forests are depicted in figure 2: Cypress for the swamp regions, where land floods frequently for long duration, and the oak type for areas with

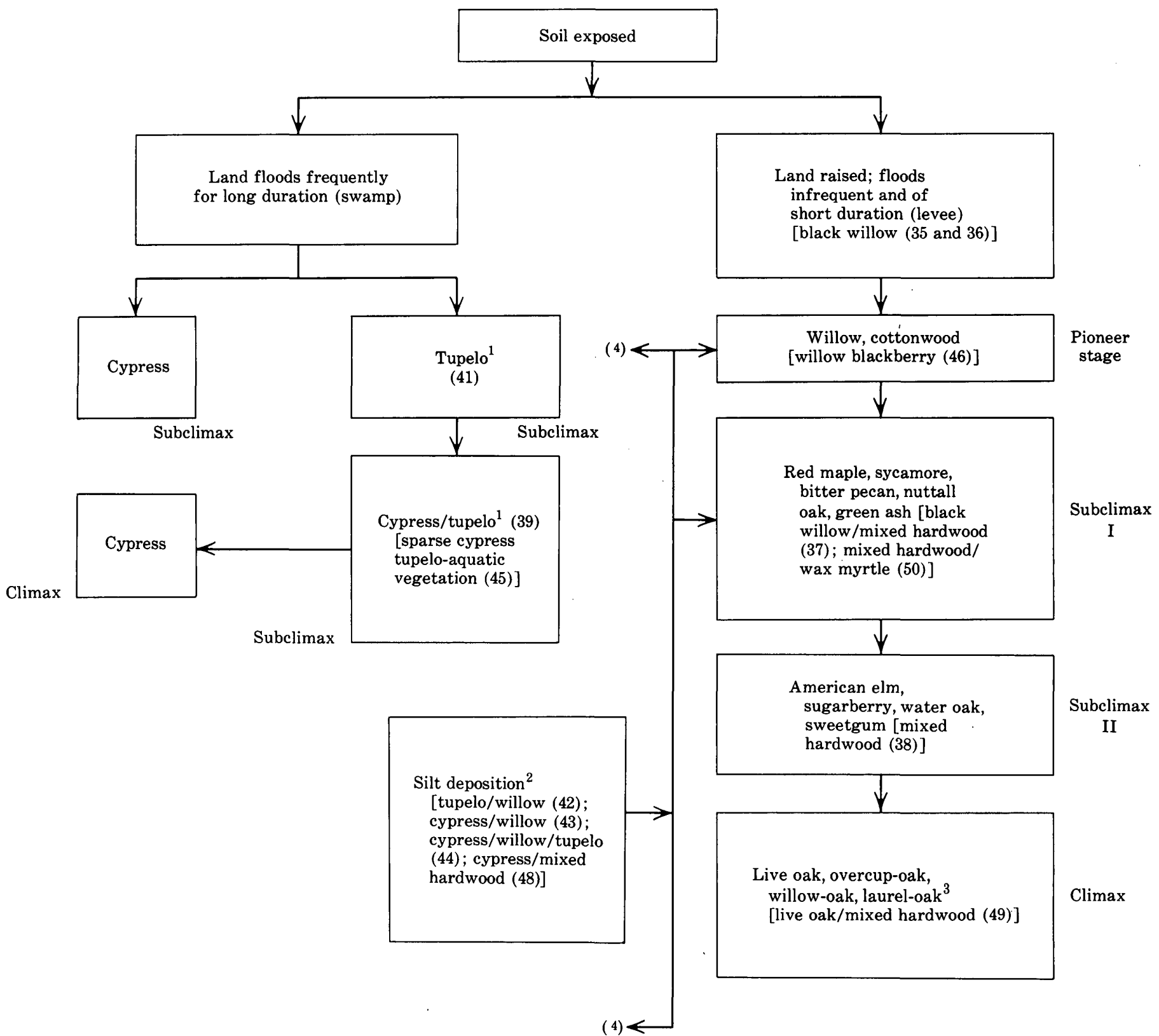

\footnotetext{
1 The tupelo and cypress/tupelo forest types may persist as a climax type, but cypress is considered the climax forest type because it is more tolerant to competition.

2 Silt deposition within swamp areas will result in transition to a levee forest.

${ }^{3}$ Live oak appears to be the dominant climax forest type south of an eastwest line approximated by the U.S. Highway 90 transect of the basin, while the overcup, willow and laurel oak climax forest type dominates the area to the north of the line.

${ }^{4}$ Introduction of, water over an extended period of time in the levee forest could result in transition to swamp forest.
} 
raised land elevations. Within the swamp areas, the succession of forest types toward a climax forest is interrupted when silt deposition results in the raising of land and improving of drainage. In such instances, willow and cottonwood become established in areas of sparse crown cover; while in areas of a dense cypress and tupelo crown cover, the more competitive hardwood species, such as red maple, bitter pecan, and green ash, become established. The forest types and associated numbers are also shown in figure 2 .

On the basis of forest succession concepts and observed forest transitions, several constraints were put on regression equation estimates. These are (A) constraint based on an inverse relation between the sum of forest type numbers 35-38 (willow/mixed hardwoods) and type 38 (cypress/tupelo, (B) a constraint based on inverse relations between forest types 35 and 36 (willow) and forest type 41 (tupelo), and (C) a constraint such that forest-acreage changes during any transition period were set to observed maximum or minimum changes if a computed value exceeded these limits for a given forest type. The inverse relations of $A$ and $B$ can be seen in the data matrix of table 2 and are consistent with forest succession concepts. The construint relations are expressed as upper limits of one type fur a given value of another type or set of types. For example, in relation $\mathrm{A}$, if the willow/mixed hardwood group sums to more than 3,200 acres $(1,295 \mathrm{ha})$, the computed value of cypress/tupelo is set to zero acres. These relations, called tupelo/willow I and II and willow/mixed hardwoods-cypress/tupelo, are given in table 5 .

Additional constraints on computed values of the regression equations are as follows: (a) Negative val-

TABLE 5.-Forest-type constraint relations

[See table 1 for explanation of forest-type Nos. 35, 36, 37, 39, and 41] Tupelo/willow relation I:

$$
\text { If Then }
$$

No. $41>300$ acres (121 ha) -- No. $35=0$

300 acres $(121 \mathrm{ha}) \geqslant$ No. $41>$

50 acres $(20 \mathrm{ha})$... No. $35 \leq 100$ acres (40 ha).

50 acres $(20 \mathrm{ha}) \geqslant$ No. 41 .... No. 35 as computed.

Tupelo/willow relation II :

$$
\text { If Then }
$$

No. $41>400$ acres $(161 \mathrm{ha})--$ No. $36=0$.

400 acres $(161 \mathrm{ha}) \geqslant$ No. $41>$

100 acres (40 ha)

100 acres $(40 \mathrm{ha}) \supseteq$ No. 41 ... No. 36 as computed.

Willow/mixed hardwoods-cypress/tupelo :

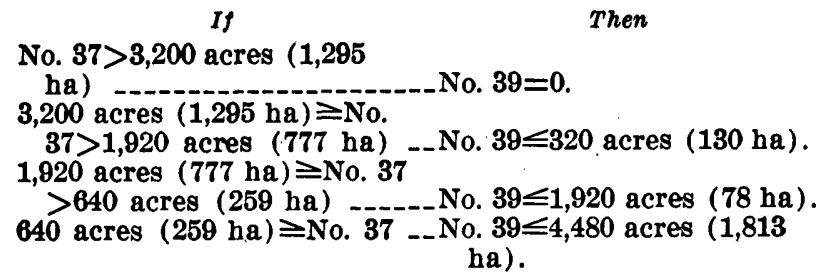
ha). ues are set to zero, and (b), if computed quadrat area exceeds $8 \mathrm{mi}^{2}\left(20.74 \mathrm{~km}^{2}\right)$, the error in area is distributed to individual computed forest-type acreages in proportion to standard errors of estimate for each type given in table 4 .

In some cases, the quadrat area is reduced to account for areas of agriculture, urban land, or other constant quantities not predictable by the forest-trend simulation model. The computation sequence of the model is summarized in figure 3.

\section{TEST OF SIMULATION METHOD}

The simulation method or model was further tested using data on two observed forest transitions, 1930-52 and 1952-73. An example computation for quadrat 5 of range 17 is shown in table 6 , and a summary of results for all 24 quadrats by forest type is given in table 7 . In addition to observed and computed total acreages of each forest type, table 7 also gives mean and standard deviation of observed and computed values for comparison. Of the 32 cases, observed and computed total forest type acreages agree within 10 percent for 6 , within 20 percent for 16 , and within 30 percent for 23 . In nine, forest type totals were in error by greater than 30 percent.

Because the same data were used to test the foresttrend simulation model as were used to define the regression relations, this test cannot be considered as a model verification. Model prediction errors for applications in other areas of the basin may be significantly larger.

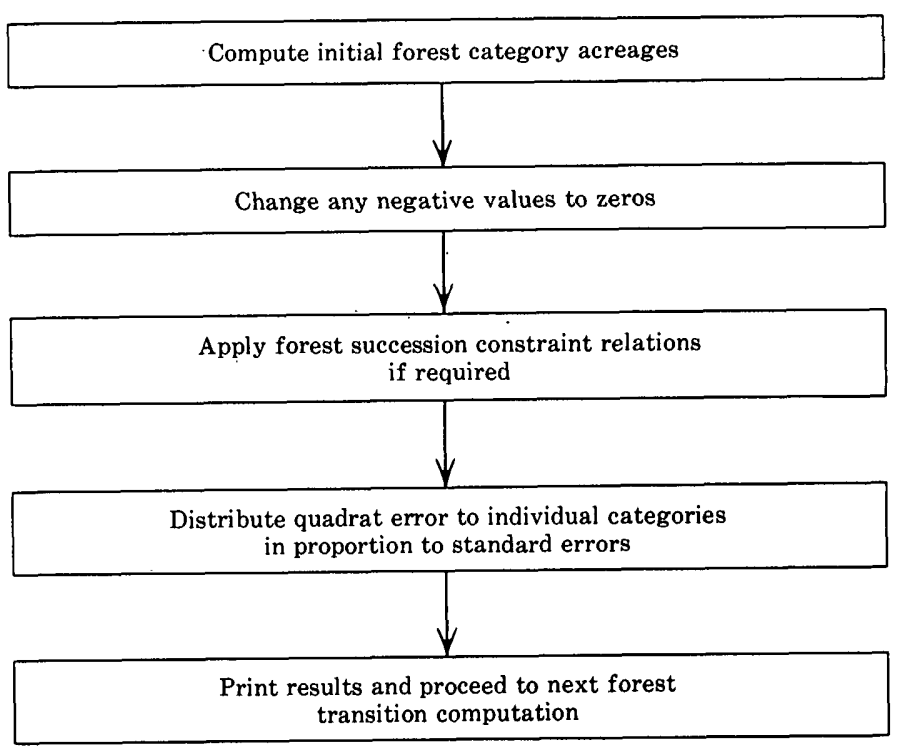

FIGURE 3.-Forest-trend simulation model. 
TABLE 6.-Example simulation for range 17, quadrat 5

\begin{tabular}{|c|c|c|c|c|c|c|c|c|c|}
\hline \multirow{2}{*}{\multicolumn{2}{|c|}{$\begin{array}{c}\text { Forest- } \\
\text { type } \\
\text { No: }\end{array}$}} & \multicolumn{4}{|c|}{ Forest transition $1930-52$} & \multicolumn{4}{|c|}{ Forest transition $1952-73$} \\
\hline & & $\begin{array}{c}\text { Computed } \\
1952 \text { acreage } \\
\text { times } 1,000 \\
\text { (unadjusted) }\end{array}$ & $\begin{array}{c}\text { Observed } \\
1952 \\
\text { acreage } \\
\text { times 1,000 }\end{array}$ & $\begin{array}{c}\text { Computed } \\
1952 \text { acreage } \\
\text { times 1,000 } \\
\text { (adjusted) }\end{array}$ & $\begin{array}{l}\text { Acreage } \\
\text { error } \\
\text { t1mes } \\
1,000\end{array}$ & $\begin{array}{c}\text { Computed } \\
1973 \text { acreage } \\
\text { times 1,000 } \\
\text { (unadjusted) }\end{array}$ & $\begin{array}{c}\text { Observed } \\
1973 \\
\text { acreage } \\
\text { times } 1,000\end{array}$ & $\begin{array}{l}\text { Computed } \\
1973 \text { acreage } \\
\text { times 1,000 } \\
\text { (adjusted) }\end{array}$ & $\begin{array}{c}\text { Acreage } \\
\text { error } \\
\text { times } \\
1,000\end{array}$ \\
\hline \multirow{17}{*}{$\begin{array}{l}35 \\
36 \\
37 \\
38 \\
39 \\
41 \\
42 \\
43 \\
44 \\
\mathbf{4 5} \\
\mathbf{4 6} \\
\mathbf{4 8} \\
\mathbf{4 9} \\
\mathbf{5 0} \\
\mathbf{5 2} \\
\mathbf{5 3}\end{array}$} & & 0.0 & 0.0832 & 0.0 & 0.0832 & 0.1898 & 0.0 & 0.2163 & -0.2163 \\
\hline & -.-.-.-. & .5089 & .0 & .4224 & -.4224 & $\begin{array}{r}.10029 \\
\end{array}$ & $\begin{array}{r}.0 \\
.0\end{array}$ & .2542 & -.2542 \\
\hline & -...-_-_-_-_. & .0 & .0 & .0 & .0 & .0291 & .0896 & .0499 & .0397 \\
\hline & - & .0755 & .0 & .0351 & -.0351 & .1143 & .0320 & .1383 & -.1063 \\
\hline & -.--_-_-_--.-. & 2.5593 & 2,7712 & 2.4340 & .3372 & .1430 & .0 & .2173 & -.2173 \\
\hline & 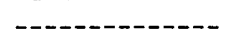 & .0048 & .4 & .0 & .0 & .0044 & .0832 & .0151 & .0681 \\
\hline & ----- & .0342 & .0 & .0272 & -.0272 & .0 & .0 & .0041 & -.0041 \\
\hline & -.............. & .0 & .0 & .0 & .0 & .0826 & .0 & .1372 & -.1372 \\
\hline & -.............. & 1.7113 & 1.8048 & 1.5749 & .2299 & 2,9908 & 4.1600 & 3.0717 & 1.0883 \\
\hline & --_- & .0642 & .0 & .0346 & -.0346 & .0 & .0 & .0176 & -.0176 \\
\hline & - & .2722 & .0 & .2499 & -.2499 & .0 & .0 & .0132 & -.0132 \\
\hline & - & .0 & .0 & .0 & .0 & .3677 & .1216 & .3820 & -.2604 \\
\hline & -_-_-_-_-_-_---_ & .0 & .0 & .0 & .0 & .0 & .0 & .0035 & -.0035 \\
\hline & - - & .0581 & .0 & .0084 & -.0084 & .0353 & .0448 & .0648 & -.0200 \\
\hline & 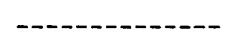 & .3630 & .4608 & .3262 & .1346 & .5069 & .5632 & .5287 & .0345 \\
\hline & +2 & .0215 & .0 & .0111 & -.0111 & .0 & .0256 & .0062 & .0194 \\
\hline & $\begin{array}{l}\text { Sum of } \\
\text { acreage }\end{array}$ & 5.6730 & 5.1200 & 5.1237 & -0.0037 & 4.6667 & 5.1200 & 5.1200 & 0.0000 \\
\hline
\end{tabular}

a Refer to table 1 for explanation of forest-type numbers.

TABLE 7.-Summary of forest-trend model simulation results. Mean and standard deviation are computed using 16 quadrats for 1952 and 24 quadrats for 1973 [Com, computed; obs, observed]

\begin{tabular}{|c|c|c|c|c|c|c|c|c|c|c|c|c|}
\hline \multicolumn{7}{|c|}{1952 results } & \multicolumn{6}{|c|}{1973 results } \\
\hline \multirow{2}{*}{$\begin{array}{l}\text { Forest- } \\
\text { type } \\
\text { No. }\end{array}$} & \multicolumn{2}{|c|}{$\begin{array}{c}\text { Acreage } \\
\text { times } 1,000\end{array}$} & \multicolumn{2}{|c|}{$\begin{array}{c}\text { Mean acreage } \\
\text { times } 1,000\end{array}$} & \multicolumn{2}{|c|}{$\begin{array}{c}\text { Standard } \\
\text { deviation } \\
\text { times } 1,000\end{array}$} & \multicolumn{2}{|c|}{$\begin{array}{c}\text { Total acreage } \\
\text { times } 1,000\end{array}$} & \multicolumn{2}{|c|}{$\begin{array}{c}\text { Mean acreage } \\
\text { times } 1,000\end{array}$} & \multicolumn{2}{|c|}{$\begin{array}{c}\text { Standard } \\
\text { deviation } \\
\text { times } 1,000 \\
\end{array}$} \\
\hline & Com & Obs & Com & Obs & Com & Obs & Com & Obs & Com & Obs & Com & Obs \\
\hline $35---$ & 2.33 & 2.56 & 0.15 & 0.16 & 0.20 & 0.23 & 1.23 & 5.53 & 0.05 & 0.24 & 0.07 & 0.43 \\
\hline $36---$ & 6.41 & 7.95 & .40 & .50 & .30 & .79 & 7.03 & 5.71 & .31 & .25 & .35 & .40 \\
\hline $37 \ldots$ & 2.24 & 1.52 & .14 & .10 & .14 & .22 & 3.39 & 3.53 & .15 & .15 & .20 & .30 \\
\hline $38 \ldots$ & 6.19 & 5.47 & .38 & .34 & .41 & .52 & 8.33 & 7.41 & .36 & .32 & .54 & .62 \\
\hline 39 & 22.70 & 17.81 & 1.41 & 1.11 & 1.22 & 1.54 & 20.54 & 16.32 & .89 & .71 & .99 & 1.21 \\
\hline $41 \ldots$ & 2.89 & 3.08 & .18 & .19 & .38 & .40 & 8.03 & 8.51 & .34 & .36 & .57 & .62 \\
\hline $42 \quad---$ & .67 & .48 & .04 & .03 & .03 & .06 & .84 & .10 & .03 & .004 & .03 & .02 \\
\hline $43 \ldots$ & 6.01 & 7.28 & .38 & .45 & .76 & .89 & 6.88 & 8.16 & .30 & .36 & .55 & .83 \\
\hline $44 \ldots$ & 6.92 & 10.06 & .43 & .63 & .60 & .72 & 20.92 & 23.61 & .91 & 1.03 & .99 & 1.47 \\
\hline 45 & 1.58 & 2.35 & .10 & .15 & .10 & .30 & 2.57 & .23 & .12 & .01 & .13 & .04 \\
\hline 46 & 1.92 & .0 & .12 & .0 & .10 & .0 & 2.43 & .65 & .10 & .03 & .11 & .07 \\
\hline 48 & .49 & .42 & .03 & .03 & .05 & .07 & 5.03 & 3.82 & .22 & .17 & .17 & .23 \\
\hline 49 & .07 & .0 & .0 & .0 & .0 & .0 & .96 & 1.09 & .04 & .05 & .12 & .12 \\
\hline 50 & 4.61 & 4.59 & .28 & .28 & .28 & .48 & 4.57 & 4.39 & .20 & .19 & .21 & .36 \\
\hline 52 & 8.81 & 10.03 & .55 & .63 & .33 & .36 & 14.90 & 19.06 & .65 & .83 & .44 & .49 \\
\hline $53----$ & 1.46 & 1.65 & .09 & .10 & .09 & .16 & 1.53 & .97 & .07 & .04 & .07 & .05 \\
\hline
\end{tabular}

a Refers to table 1 for explanation of forest-type numbers.

\section{DISCUSSION OF RESULTS}

Current studies on the Atchafalaya basin include mathematical modeling of flow and sediment movement in the basin below Simmesport, La. The results of these modeling studies for various alternative basinmanagement plans will provide sets of estimates of hydrologic variables shown in table 3 for all quadrat areas in the basin. Estimates of required initial acreages of forest types can be made from existing semidetailed basin-vegetation maps. Thus, the forest-trend simulation model can be applied for forest-trend prediction and ecosystem analysis under various alternative basin water-management plans.
The results of this study, based on one set of data, show that forest-trend predictions for total forest-type acreages were within 30 percent of actual values in twothirds of cases. The estimates appeared to be unbiased. Predictions of changes in forest trends within individual quadrats are subject to somewhat larger errors that may approach the standard error of estimates for given forest types.

Several uses of the forest-trend simulation model are indicated. For example, comparisons of forest trends at selected quadrats or on a basin-wide basis for proposed basin alternatives could be made. Forest-management units could also be designed in certain areas of 
the basin by inspection for favorable hydrologic conditions and by use of forest-succession concepts. Such management units could then be simulated to ensure that they would be maintained under a given basin water-management plan. Because such forest-management units form the basis for stable ecosystems, models of understory vegetation trends, key animal populations, and aquatic environments could be appended to the basic forest-trend simulation model.

\section{REFERENCES CITED}

Botkin, D. B., and Miller, R. S., 1974, Complex ecosystemsmodels and predictions: Am. Scientist, v. 62, p. 448-453.
U.S. Army Corps of Engineers, 1930-1964, Stages of the Mississippi River and of its principal tributaries; Mississippl River Comm., Vicksburg, Miss.

1965-1969, Stages and discharges of the Mississippi River and tributaries and other watersheds in the New Orleans district: U.S. Army Engineer District, New Orleans, La.

U.S. Army Corps of Engineers, 1974, Basic hydrologic data, in Atchafalaya basin environmental impact statement preliminary draft: U.S. Army Engineer District, New Orleans, La., app. II-2-A, 241 pls.

University of California, 1968, BMDO2R, stepwise regression, in Dixon, W. J. ed., BMD, Biomedical computer programs: ed. W. J. Dixon, Los Angeles, Univ. California Press, 600 p. 


\title{
EVALUATION OF THREE COLLECTING METHODS FOR A RECONNAISSANCE OF STREAM BENTHIC INVERTEBRATES
}

\author{
By K. V. SLACK, J. W. NAUMAN, and L. J. TILLEY, \\ Menlo Park, Calif., Anchorage, Alaska, Menlo Park, Calif.
}

\begin{abstract}
A 1-day reconnaissance of the Dietrich River, Alaska, included collection of benthic invertebrates. Three methods were used at each of five stations to increase sampling effectiveness and to evaluate each method. Chironomidae and Plecoptera comprised 91 percent of all individuals and 47 percent of all taxa in the combined faunal list. At each station, the most abundant organisms were taken by all methods but the less abundant ones by only one or two methods. The dip net collected the highest percentage of taxa, and the second highest percentage of individuals. The 10-rock method collected the highest percentage of individuals but was relatively ineffective for taxa. The drift net collected the fewest individuals, but the percentage of taxa was relatively high. Of the 27 unique taxa (those taxa collected by only one of the methods), 15 were collected by dip net, 8 by drift net, and 4 by the 10-rock method. The methods differed in their effectiveness with regard to collecting the most abundant taxonomic groups. Although the dip net was most effective for collecting taxa, more thorough scrubbing of substrates to remove clinging organisms probably would improve the technique.
\end{abstract}

Information on benthic invertebrates is increasingly included in water-quality investigations. Frequently a faunal survey is required, either as a major objective or as a preliminary to a quantitative study of the benthos (Elliott, 1971a). Faunal surveys usually attempt to determine the species present and their relative abundances by collecting from a large area at each sample site. Many different sampling methods are in use depending upon the type of environment, objectives, and the experience and preference of the investigator. Although attempts have been made to compare the effectiveness of different methods (Macan, 1958; Albrecht, 1959; Cummins, 1962; Morgan and Egglishaw, 1965), little standardization has occurred. This report compares collections of benthic invertebrates made by three methods during a limnological reconnaissance of the Dietrich River, Alaska. The three methods were used at each of five sampling stations to obtain as complete coverage as possible and to evaluate the relative effectiveness of the reconnaissance sampling methods.

\section{SETTING}

The Dietrich River, a stream in the Yukon drainage basin, arises south of the Continental Divide in the eastcentral Brooks Range at an altitude of 2,041 metres above sea level. The study area is in the Arctic Mountains Physiographic Province, 64 kilometres north of Wiseman, Alaska, and $390 \mathrm{~km}$ north of Fairbanks. Characteristics of the sampling stations are shown in table 1.

TABLE 1-Characteristics of sampling stations, Dietrich River, Alaska, August 2s, 1971

\begin{tabular}{|c|c|c|c|c|c|c|c|}
\hline $\begin{array}{l}\text { Sta- } \\
\text { tion }\end{array}$ & $\begin{array}{c}\text { Drain- } \\
\text { age } \\
\text { area } \\
\left(\mathrm{km}^{2}\right)\end{array}$ & $\begin{array}{l}\text { Altt. } \\
\text { tude } \\
\text { (m) }\end{array}$ & $\begin{array}{c}\text { Chan- } \\
\text { nel } \\
\text { gradi- } \\
\text { ent } \\
(\mathrm{m} / \mathrm{km}) \mathrm{a}\end{array}$ & $\begin{array}{c}\text { Esti- } \\
\text { mated } \\
\text { dis- } \\
\text { charge } \\
\left(\mathrm{m}^{8} / \mathrm{s}\right)\end{array}$ & $\begin{array}{c}\text { Width } \\
\text { (m) }\end{array}$ & $\begin{array}{l}\text { Depth } \\
\text { (mm) }\end{array}$ & Bed \\
\hline & $\begin{array}{c}0.1 \\
31 \\
90 \\
223\end{array}$ & $\begin{array}{r}1524 \\
915 \\
716 \\
591\end{array}$ & $\begin{array}{c}300^{\mathrm{b}} \\
30 \\
19 \\
7\end{array}$ & $\begin{array}{l}0.05 \\
1.5 \\
1.4 \\
2.7\end{array}$ & $\begin{array}{l}1.6 \\
4.5 \\
11 \\
12\end{array}$ & $\begin{array}{r}50 \\
120 \\
220 \\
220\end{array}$ & \multirow{2}{*}{$\begin{array}{c}\text { Cobble, gravel. } \\
\text { Do. } \\
\text { Do. } \\
\text { Cobble, gravel, } \\
\text { and sand. } \\
\text { Cobble, gravel. }\end{array}$} \\
\hline --------- & $\mathbf{7 7 0}$ & 462 & 3 & 3.5 & 15 & 460 & \\
\hline
\end{tabular}

Determined using the nearest upstream and downstream contour on the $1: 63,360$ scale map (100-ft contour interval).

Approximate.

\section{METHODS}

Benthic invertebrates were collected as follows: A 1-hour daylight drift-net sample was obtained upstream from the area disturbed by other sampling. The net was equipped with nylon screen cloth (Nitex) with 471-micrometre mesh and its 30 - by 30 -centimetre opening was held perpendicular to the current by rods driven into the bed. The ratio of the area of net opening to filtering surface of the mesh bag was $1: 2.6$ and to open space in the mesh bag was $1: 1.4$. The bottom of the net frame was in contact with the streambed, and the top extended above the water surface. McLay (1970) and Elliott (1971b) showed that organisms in the drift are not carried from far upstream, but as the distance upstream from the sampling point increases each unit area of bottom contributes a progressively smaller proportion of drifting invertebrates 
to the total catch. Consequently, drift organisms are assumed to have originated in the same type of environment sampled by the other methods.

A D-shaped dip net of nylon screen cloth with 210$\mu \mathrm{m}$ mesh was used to collect from the major aquatic habitats. Collecting was conducted for 45 minutes, and the effort in a given habitat was approximately in proportion to the amount of that habitat at the station. Most collecting, therefore, was in rocky riffles.

Ten streambed rocks about 100 to 200 millimetres in diameter were lifted at random from the major habitats. As each rock was lifted off the bottom, it was enclosed in a net to minimize loss of organisms. The rocks were scrubbed with a brush in a bucket of water, and the residue concentrated on a U.S. Standard No. 70 sieve $(210-\mu \mathrm{m}$ mesh $)$. The same individual collected with the dip net and with the 10-rock method at all stations.

Preserved samples were sorted using the sugar flotation method (Anderson, 1959), and the residue was examined under a dissecting microscope to recover organisms missed. Because the taxonomy of Alaskan freshwater invertebrates is poorly known, it was not possible to assign specific names to many specimens. However, organisms, especially insects, were separated and enumerated to taxa that as nearly as possible correspond to species.

Data from the three methods were combined to produce a total faunal list for each station; the station lists were combined to obtain a total faunal list for the stream. These lists were the basis for comparing the relative effectiveness of each collection method. The composition of the benthic invertebrate collections is described by the number of taxa and their relative abundances. These descriptive properties can be expressed in terms of diversity and evenness (Pielou, 1969). A collection has high diversity if it has many taxa and their abundances are fairly even; diversity is low when the taxa are few and their abundances uneven. Diversity index values in table 2 were calculated using the formula of Brillouin (1962) expressed in bits. Evenness is the ratio of the calculated diversity of a collection to the maximum it would have given the same number of taxa. Maximum evenness is attained when the individuals are divided equally among the taxa (Pielou, 1969).

\section{RESULTS}

Considering the combined benthic invertebrate list for the Dietrich River, the dipteran family Chironomidae comprised the greatest number of taxa and individuals, 39 and 71 percent, respectively. Order Plecoptera was the second most abundant group. These two insect groups together made up 47 percent of the taxa and 91 percent of the individuals. Ephemeroptera, Collembola, aquatic Acarina, Oligochaeta, and other Diptera were prominent among the remaining taxa and individuals (K. V. Slack, J. W. Nauman, and L. J. Tilley, written commun., 1975).

At each of the stations, the most abundant organisms were taken by all the methods but the less abundant ones by only one or two methods. About one-quarter (28 percent) of the Dietrich River taxa were taken by all methods at one or more stations. These taxa accounted for about three-quarters (78 percent) of the total number of individuals. In contrast, more than half ( 57 percent) of the taxa were taken by a single method at one or more stations. These taxa accounted for only one-tenth (10 percent) of the individuals.

The proportion of each station list contributed by each method is shown in figure 1. The dip net collected the greatest number of taxa at all stations and the 10rock method the least. The 10-rock method resulted in the collection of the greatest number of individuals and the drift net the least.

Diversity and evenness values for collections made by the different methods and for the combined collections are given in table 2. The importance of uniform sampling methods for comparing diversity of collections was emphasized by Hughes (1975). The values in the table are given merely to show the range of index values that would have been available if collections had been made by a single method. In general, diversity and evenness were highest for drift-net collections. Ten-rock collections had the lowest diversity and dip-

TABLE 2.-Diversity and evenness of benthic invertebrate collections made by three methods, Dietrich River, Alaska, August 23, 1971

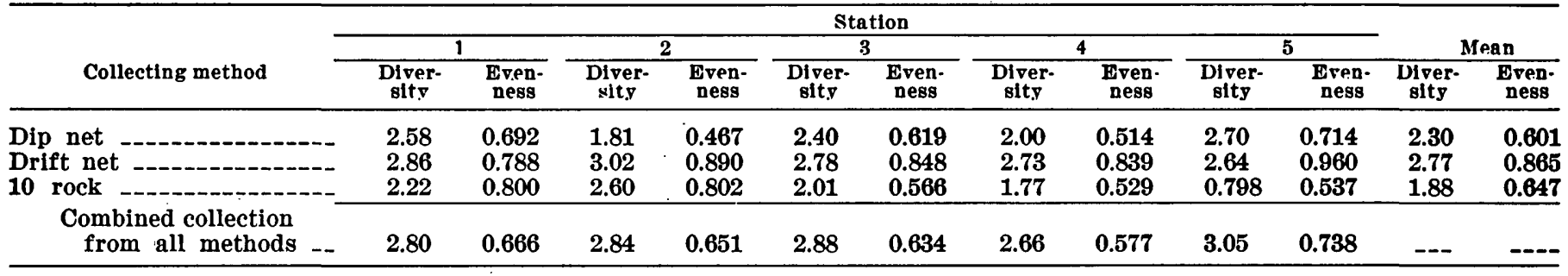



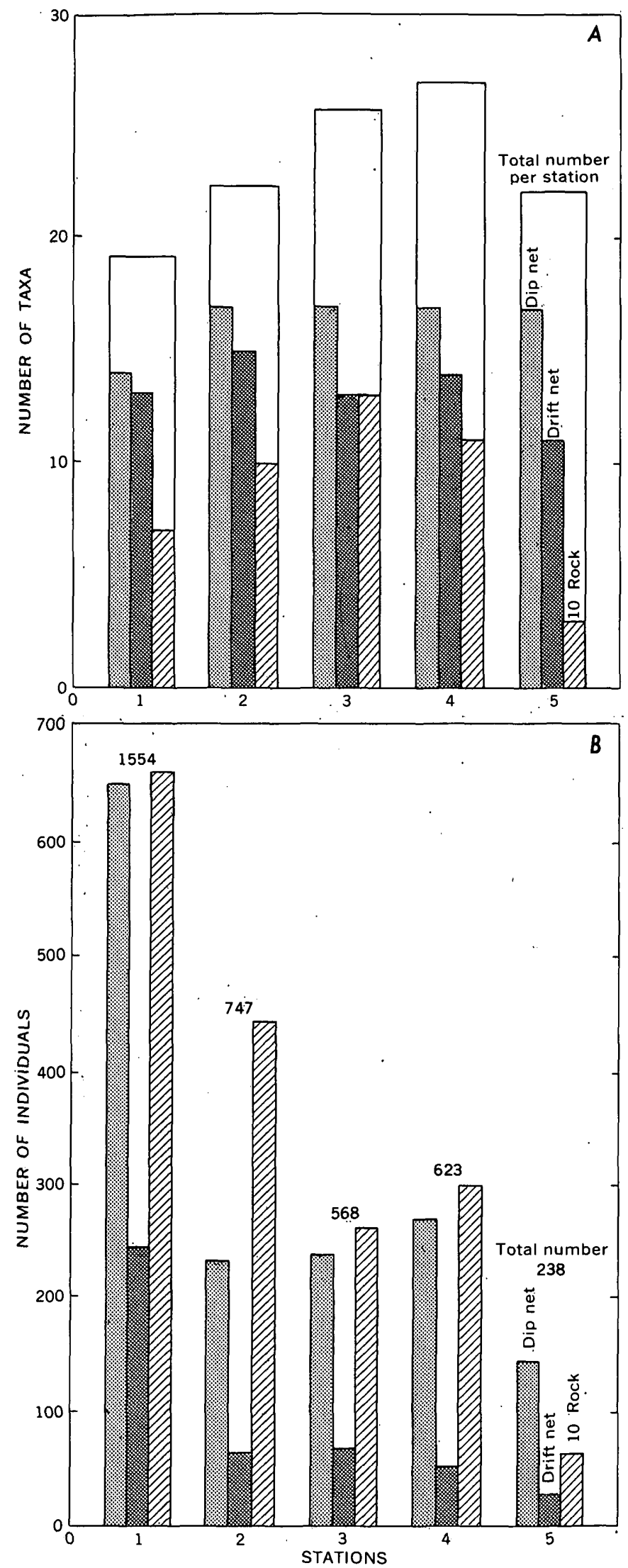

net and 10-rock collections the lowest evenness. Diversity values are variable from station to station but are lower than those reported by Wilhm (1970) for uncontaminated streams in temperate regions.

\section{Relative contribution to stream faunal list}

The proportion of the total (combined) list of benthic invertebrates contributed by each method is shown in table 3. The dip net collected the highest percentage of taxa and the second highest percentage of individuals. The 10-rock method resulted in the collection of the highest percentage of individuals but was relatively ineffective in collecting taxa. The drift net collected the fewest individuals, but loss of small organisms through the $471-\mu \mathrm{m}$ mesh possibly contributed to the low numbers. The number of taxa was relatively, high for the drift collections.

\section{Relative effectiveness of methods for collecting particular groups}

Methods as diverse as those used in this investigation probably will exhibit different selectivities in sampling the benthic fauna. Results for the most abundant taxonomic groups (table 3) support that assumption. The dip-net collections contained the greatest numbers of Plecoptera and Ephemeroptera. The 10-rock-method collections contained the greatest number of Simuliidae taxa and chironomid individuals, possibly because scrubbing the rocks resulted in more complete recovery of larvae from the surfaces of rocks or from tufts of algae and moss. Maximum numbers of Diamesinae taxa and Collembola and Acarina taxa and individuals occurred in drift collections. The occurrence of the latter groups in the drift is to be expected because of their abundance in riparian environments (Watson and others, 1966).

The relative effectiveness of each method in collecting benthic invertebrates also can be expressed as the number of unique taxa (table 4). Unique taxa are those collected by only one of the three methods. Although the dip net collected more unique taxa and individuals than were taken by the other two methods combined, it is significant that all methods yielded some unique taxa.

\section{Other invertebrates}

The collections included some terrestrial invertebrates and adults and pupae of aquatic insects not a

Fiaure 1.-Comparison of number of benthic invertebrate taxa $(A)$ and individuals $(B)$ collected by three methods, Dietrich River, Alaska, August 23, 1971. The total number of taxa per station is less than the sum of the three collections because many taxa occurred in more than one collection. 
TABLE 3.-Relative contribution of each method to the collection of major groups and to the total list of benthic invertebrates, Dietrich River, Alaska, August 28, 1971

\begin{tabular}{|c|c|c|c|c|c|c|c|c|c|c|c|}
\hline \multirow[t]{2}{*}{$\operatorname{Taxa}$} & \multirow[t]{2}{*}{$\begin{array}{l}\text { Number } \\
\text { of taxa }\end{array}$} & \multirow[t]{2}{*}{$\begin{array}{c}\text { Number of } \\
\text { individuals }\end{array}$} & \multicolumn{3}{|c|}{$\begin{array}{l}\text { Percentage of taxa } \\
\text { collected by }\end{array}$} & \multicolumn{3}{|c|}{$\begin{array}{c}\text { Percentage } \\
\text { of individuals } \\
\text { collected by- }\end{array}$} & \multicolumn{3}{|c|}{$\begin{array}{l}\text { Average number } \\
\text { of individuals } \\
\text { per taxon }\end{array}$} \\
\hline & & & Dip & Drift & 10 rock & Dip & Drift & 10 rock & Dip & Drift & 10 rock \\
\hline Diamesinae ... & 7 & 1643 & 85.7 & 100.0 & 85.7 & 36.2 & 12.0 & 51.8 & 99 & 28 & 142 \\
\hline Orthocladiinae & 11 & 1008 & 72.7 & 72.7 & 54.6 & 20.8 & 9.6 & 69.4 & 26 & 12 & 117 \\
\hline Plecoptera & 4 & 754 & 100.0 & 75.0 & 50.0 & 77.6 & 3.8 & 18.6 & 146 & 10 & 70 \\
\hline Simuliidae & 2 & 117 & 50.0 & 50.0 & 100.0 & $\mathbf{3 3 . 3}$ & 29.1 & 37.6 & 39 & 34 & 22 \\
\hline Ephemeroptera & 7 & 26 & 100.0 & 0 & 0 & 100.0 & 0 & 0 & 4 & 0 & 0 \\
\hline Collembola & 3 & 53 & 66.7 & 100.0 & 0 & 11.3 & 88.7 & $\mathbf{0}$ & $\mathbf{3}$ & 16 & $\mathbf{0}$ \\
\hline Aquatic Acarina & 3 & 42 & 66.7 & 100.0 & 33.3 & 14.3 & 83.3 & 2.4 & 3 & 12 & 1 \\
\hline Total benthic & & & & & & & & & & & \\
\hline invertebrates & 49 & $\mathbf{3 7 3 0}$ & 77.6 & 55.1 & 40.8 & 41.2 & 12.2 & 46.6 & 40 & 17 & 87 \\
\hline
\end{tabular}

TABLE 4.-Number of unique taxa and individuals obtained by each collection method, Dietrich River, Alaska, August 2S, 1971

\begin{tabular}{lccc}
\hline $\begin{array}{c}\text { Collecting } \\
\text { method }\end{array}$ & $\begin{array}{c}\text { Number of } \\
\text { unique } \\
\text { taxa a }\end{array}$ & $\begin{array}{c}\text { Number of } \\
\text { individuals }\end{array}$ & $\begin{array}{c}\text { Mean number } \\
\text { of individuals } \\
\text { per unique taxon }\end{array}$ \\
\hline Dip net & 15 & 47 & 3.1 \\
Drift net ---- & 8 & 25 & 3.1 \\
10 rock $-0--$ & 4 & 4 & 1.0 \\
\hline
\end{tabular}

a Collected by only one of the three methods.

TABLE 5.-Numbers of other (nonbenthic) taxa and individuals collected by three methods, Dietrich River, Alaska, August 23, $19 \gamma 1$

\begin{tabular}{lrrrrr}
\hline \multirow{2}{*}{$\begin{array}{c}\text { Collecting } \\
\text { method }\end{array}$} & \multicolumn{2}{c}{ Chironomidae } & & \multicolumn{2}{c}{ All invertebrates } \\
& Taxa & Individuals & & Taxa & Individuals \\
\hline Dip net & 7 & 38 & & 9 & 40 \\
Drift net --- & 16 & 405 & & 38 & 549 \\
10 rock ---- & 5 & 16 & & 7 & 18 \\
\hline
\end{tabular}

part of the benthic fauna. Because these groups may be of interest in some studies, the relative effectiveness of the collecting methods is summarized in table 5 . The Chironomidae dominated the nonbenthic collections, and the drift nets collected most of the taxa and individùals. Sixty percent of the chironomid pupae and all the chironomid adults were in drift collections. Dip net samples contained 28 percent of the pupae. The 10-rock collections contained the fewest nonbenthic organisms.

\section{DISCUSSION}

At least two factors are involved in determining the effectiveness of methods for collecting a particular organism; namely, the likelihood of the organism being present at the precise time and place of sampling, and the likelihood of capturing the organism with the equipment and technique employed. Considering the coincidence of collector and target organism, various statistical procedures are available for design of sampling programs, but limited field time prevented their use in this study. In qualitative terms, however, the dip-net method provided maximum coverage of diverse habitats compared to the other methods. This re- sulted in maximum opportunity for collecting different taxa as was in fact observed (tables 3 and 4). The 10-rock method by definition was restricted to the stone-dwelling fauna but includes organisms associated with attached algae and mass. The number of taxa in the collections was low, but the number of individuals per taxon was high (table 3) suggesting large populations. The drift net collected some fraction of the benthic fauna entrained in streamflow during the sampling period. More than half of the total number of benthic taxa from the Dietrich River occurred in these collections. In addition, the drift net was the only method that effectively collected aquatic pupae and adults and terrestrial invertebrates. The large mesh of the drift net (471 versus $210 \mu \mathrm{m}$ ) compared to that used with the other methods was previously mentioned as a possible factor in the low numbers of individuals in drift collections. The larger mesh also may have resulted in the loss of taxa.

Although advantages of drift versus benthos sampling have been discussed by Waters (1961) and Larimore (1974), the relative effectiveness of the 1-hour daylight drift collection for capturing benthic taxa was unexpected. Investigation of diel periodicity has established that some aquatic organisms are day active and others are night active (Müller, 1966). The rate of drift for a particular species generally increases during its period of activity. Because all the Dietrich River collections were obtained during daylight, the drift collections are presumed to have a bias for dayactive species. However, Hynes and others (1974) reported that the rate of drift of chironomid larvae did not vary with the time of day in a Canadian arctic river. Thus, the drift-net technique used in this study may be especially effective in streams in which Chironomidae are the most abundant organisms.

\section{CONCLUSION}

Results of this study have implications for future biological investigations. The number of taxa collected 
from a station was increased when more than one collecting method was used, although the most abundant taxa were collected by all three methods. The dip net was the single most effective method for collecting taxa, the objective of the faunal survey. However, the technique probably could be improved by more thorough scrubbing of substrate surfaces to dislodge tightly clinging organisms. A simple drift net may provide valuable information about the benthic fauna. Because it is a passive technique that requires little specialized training and a minimum of field time, the drift net is especially adaptable for studies in which other collecting methods are not feasible. The mesh sizes of nets and sieves used for benthic invertebrate collecting should be uniform for a particular investigation.

\section{REFERENCES CITED}

Albrecht, M.-L., 1959, Die quantitative Untersuchung der Bodenfauna fliessender Gewässer (Untersuchungsmethoden und Arbeitsergebnisse) : Zeitschr. Fischerei, N.F., v. 8, p. 481-550.

Anderson, R. O., 1959, A modifled flotation technique for sorting bottom fauna samples: Limnology and Oceanography, v. 4 , no. 2 , p. $223-225$.

Brillouin, Leon, 1962, Science and information theory [2nd ed.] : New York, Academic Press, 351 p.

Cummins, K. W., 1962, An evaluation of some techniques for the collection and analysis of benthic samples with special emphasis on lotic waters: Am. Midland Naturalist, v. 67, p. 477-504.

Elliott, J. M., 1971a, Some methods for the statistical analysis of sumples of benthic invertebrates: Freshwater Biol. Assoc. Sci. Pub. no. 25, 148 p.
$1971 b$, The distances traveled by drifting invertebrates in a Lake District stream: Oecologia (Berlin, SpringerVerlag), v. 6, p. 350-379.

Hughes, B. D., 1975, A comparison of four samplers for benthic macro-invertebrates inhabiting coarse river deposits: Water Research, v. 9, no. 1, p. 61-69.

Hynes, H. B. N., Kaushik, N. K., Lock, M. A., Lush, D. L., Stocker, Z. S. J., Wallace, R. R., and Williams, D. D., 1974, Benthos and allochthonous organic matter in streams: Fisheries Research Board Canada Jour., v. 31, p. 545-553.

Larimore, R. W., 1974, Stream drift as an indication of water quality: Am. Fisheries Soc. Trans., v. 103, no. 3, p. 507517.

Macan, T. T., 1958, Methods of sampling the bottom fauna in stony streams: Internat. Vereinigung Limnologie Mittellungen, no. 8, p. 1-21.

McLay, Colin, 1970, A theory concerning the distance travelled by animals entering the drift of a stream: Fisheries Research Board Canada Jour., v. 27, p. 359-370.

Morgan, N. C., and Egglishaw, H. .J., 1965, A survey of the bottom fauna of streams in the Scottish Highlands. Part I, Composition of the fauna: Hydroblologia, v. 25, p. 181211.

Müller, Karl, 1966, Die Tagesperiodik von Fleisswasserorganismen: Berlin, Zeitschr. Morphologie Ökologie Tiere, v. 56, p. 93-142.

Pielou, E. C., 1969, An introduction to mathematical ecology: New York, Wiley-Interscience, $286 \mathrm{p}$.

Waters, T. F., 1961, Standing crop and drift of stream bottom organisms: Ecology, v. 42, no. 3, p. 532-537.

Watson, D. G., Davis, J. J., and Hanson, W. C., 1966, Terrestrial invertebrates, in Wilimovsky, N. J. and Wolfe, J. N. eds., Environment of the Cape Thompson Region, Alaska: U.S. Atomic Energy Commission, PNE-481, p. 565-584.

Wilhm, J. L., 1970, Range of diversity index in benthic macroinvertebrate populations: Water Pollution Control Federation Jour., v. 42, no. 5, pt. 2, p. R221-R224. 


\title{
AN EVALUATION OF METHODS FOR MEASURING ALGAL GROWTH
}

\author{
By W. THOMAS SHOAF and BRUCE W. LIUM, Doraville, Ga.
}

\begin{abstract}
Algal growth was expressed as milligrams dry weight per litre with use of the electronic particle counter for determining cell number and cell volume. A gravimetric constant in milligrams dry weight per cubic micrometre was determined. This constant was applicable throughout the growth curve since there was a linear relationship between total cell weight and total cell volume. Cell volume must be considered in measuring growth because there is a change in average cell volume in addition to an increase in cell numbers throughout the growth curve. Chlorella vulgaris and Selenastrum capricornutum exhibited similar growth curves when growth was expressed as cells per litre or as milligrams dry weight per litre. Chlamydomonas reinhardtii appeared to have a lower algal growth potential when measured in cells per litre but had the same growth potential as $C$. vulgaris and S. capricornutum when expressed as milligrams dry weight per litre. The growth rate for Scenedesmus quadricauda was less than the other three, regardless of how the results were expressed. The image analysis system was used to count different types of algae in a mixed culture. C. reinhardtii, $C$. vulgaris, and Anacystis nidulans were not grossly distorted by the sample preparation method and could be distinguished from one another by variations in morphology. The counts could be separated by computing the ratio of area to. length for each particle and by allowing the computer to sort and count each of the three types. Typical ratios ranged from 5 to 7 for $C$. reinhardtii, 2 to 4 C. vulgaris, and 0.2 to 1.3 for A. nidulans. The number of types to be counted in a mixture was limited only by the ability to apply shape factors without having an overlap between each type. Both the image analysis and electronic particle counter produced equal count and size measurements. Fluorescence was a sensitive measure of growth on a laboratory prepared medium since there was a logarithmic relationship between fluorescence and cells per millilitre for both $C$. vulgaris and $S$. capricornutum. Fluorescence measurements were not satisfactory for determining growth in samples of varying chemical composition (which occurs in natural samples) because the chlorophyll-to-cell ratio varied with media composition. This was especially pronounced with $O$. vulgaris.
\end{abstract}

Several methods are available for the determination of algal growth rates. Optical density, oxygen production, and carbon dioxide uptake measurements and microscopic cell counts and cell mass determinations have been used. These are not sensitive enough to determine algal growth when the number of cells is small. The measurement of carbon-14 uptake is a sensitive but time-consuming method. This paper compares three of the more rapid and sensitive methods, the electronic particle counter (Hastings and others, 1962; Kuhl and Lorenzen, 1964; Maloney and others, $1972)$; a relatively new method, electronic image analysis; and in vivo fluorescence(R. L. Brown, R. C. Bain, and M. G. Tunzi, written commun., 1969; Wang and others, 1972).

\section{MATERIALS AND METHODS}

\section{Electronic particle counting and sizing}

The electronic particle counter (Coulter Electronics, Inc.) utilizes the fact that algal cells are relatively poor conductors of electricity. The algal cells are suspended in an electrolyte, and as they pass through a small aperture across which an electric current has been established, each cell causes a voltage drop that is recorded as a count. The height of the pulses resulting from the voltage drop as an algal cell passes through the aperture is proportional to cell volume. The knowledge of both the change in number of particles (cells or colonies) per unit volume (of culture medium) and the change in mean particle (cell or colony) volume allows growth rates to be measured accurately and reproducibly. The results can be converted to milligrams per litre by determining the dry weight per cubic micrometre and using the following equation:

$$
\begin{aligned}
\frac{\text { particles }}{\text { millilitre }} \times \frac{\text { cubic micrometre }}{\text { particle }} & \times \frac{\text { microgram }}{\text { cubic micrometre }} \\
= & \frac{\text { microgram }}{\text { millilitre }}=\frac{\text { milligram }}{\text { litre }} .
\end{aligned}
$$

The dry weight per cubic micrometre was obtained by filtering algae cultures (whose mean particle volume is known) through prewashed and dried tared filters $(0.45-\mu \mathrm{m}$ pore size, $25 \mathrm{~mm}$ diam). The filtered material was then dried to constant weight at $55^{\circ} \mathrm{C}$. The filters were weighed on an electrobalance (model 4400, Cahn Instruments, Inc.) after removing static electricity by passing both sides of the filter across a radioactive ionizing unit (Cahn) at a distance of no more than $2.5 \mathrm{~cm}$. 
Image analysis

The electronic image analysis technique (Millipore $\pi \mathrm{MC}$ ) used a microscope, television camera and screen, and a computer (model 600, Wang Lab., Inc.) to collect and process the image data. In this procedure the algae must be randomly distributed (such as occurs with membrane filtration) and, for optimum performance, they should all lie in a single plane on a clear slide. The method consisted of wetting the filter (25 $\mathrm{mm}, 0.45-\mu \mathrm{m}$ pore size) with filtered 95 percent ethanol, pouring approximately $5 \mathrm{ml} 95$ percent ethanol above the filter in the filter holder, adding a small aqueous sample, mixing, and immediately filtering. The filter was then "rolled" onto a slide covered with 95 percent ethanol and the filter was placed on another slide. The latter slide was inverted and positioned so that the filter was over a beaker containing acetone. The beaker was then covered. In approximately 2 minutes, the acetone vapors cleared the filter. The slide was removed immediately and placed in an oven at approximately $55^{\circ} \mathrm{C}$ to dry for approximately 3 minutes. The slide was then positioned properly and the microscope was focused for image analysis.

\section{Fluorescence measurements}

In vivo chlorophyll fluorescence of algal cultures was measured with a filter fluorometer (model 110, G. K. Turner Associates). The fluorometer was modified with a red sensitive photomultiplier (Turner No. R-136) to detect chlorophyll fluorescence at the longer wavelengths. A primary filter with maximum transmission at 436 nanometres (Turner Nos. 813 and 816 ) and a secondary filter which transmits light above $595 \mathrm{~nm}$ (Turner No. 802) were used with the instrument.

\section{Source of test algae and growth conditions}

Three species of algae were obtained from the culture collection of algae at Indiana University (Starr, 1964). These were Chlamydomonas reinhardtii (No. 89), Scenedesmus quadricauda (No. 76) and Anacystis nidulans (No. 625). Chlorella vulgaris Beijerinck was obtained from John Heiss, Georgia Institute of Technology. Selenastrum capricornutum Printz was obtained from the U.S. Environmental Protection Agency, Pacific Northwest Environmental Research Laboratory, Corvallis, Oreg. All algae were routinely cultured on the medium and under conditions described in the provisional algal assay procedures (Bartsch, 1971). Some of the algae were unicellular and some colonial, thus it was not always applicable to test all five in every experiment.

\section{RESULTS AND DISCUSSION}

\section{Electronic particle counter}

The lower threshold dial setting of the electronic particle counter must be determined first because this setting determines the lower size limit of the count. The setting should be above background electrical noise but not so high as to screen out smaller algae. As an example, figure 1 is a graph of lower threshold settings versus counts and shows that the appropriate region for counting is between a setting of 5 and 15 for both Selenastrum capricornutum and Chlorella vulgaris. The initial sharp decrease in counts was a result of screening out background electrical noise, whereas the slower decrease was a result of the removal of successively larger countable algal cells. The plateau from 5 to 15 was a size region smaller than the smallest algal cell counted but larger than background noise spikes.

The effect of doubling the amplification on the size distribution curve, for example, with a culture of $S$. capricornutum, is seen in figure 2 . With the reciprocal aperture-current switch set at $1 / 4$ and the reciprocal amplification switch set at 8 (so that each channel number equals $5 \mu \mathrm{m}^{3}$ ), a size distribution curve with a peak at channel number 8 is obtained. When the amplification is doubled (each channel number now represents $2.5 \mu \mathrm{m}^{3}$ ) to a value of 4 (reciprocal amplification), a broader size distribution curve with a peak at 16 is obtained. With settings of 2 (each channel number equals $1.25 \mu \mathrm{m}^{3}$ ) and 1 (channel number equals 0.625 $\mu \mathrm{m}^{3}$ ), the peaks are at channels 32 and 64 , respectively. Thus, irrespective of what setting is selected (so that all particles are counted) the average cell volume obtained is the same.

The growth of four pure algal cultures was determined with the electronic particle counter, both by counting cell numbers and by incorporating the change in cell volume with the change in cell number to obtain growth as milligrams dry weight per litre. Three of the algae were unicellular: two greens, $C$. vulgaris and S. capricornutum, and a flagellate, Chlamydomonas reinhardtii; the other was a green colonial form, Scenedesmus quadricauda. As seen in figure $3 \mathrm{~A}$, the number of particles (cells or colonies) per unit volume for each of the four algae at stationary phase was different. The maximum growth rate for the colonial alga $S$. quadricauda was less than that for the unicellular forms $C$. vulgaris, $S$. capricornutum, and $C$. reinhardtii. During the period of increase in cell numbers from early logarithmic phase to stationary phase, there was an increase in the average particle (cell) volume. The range of average cell volumes is given in 

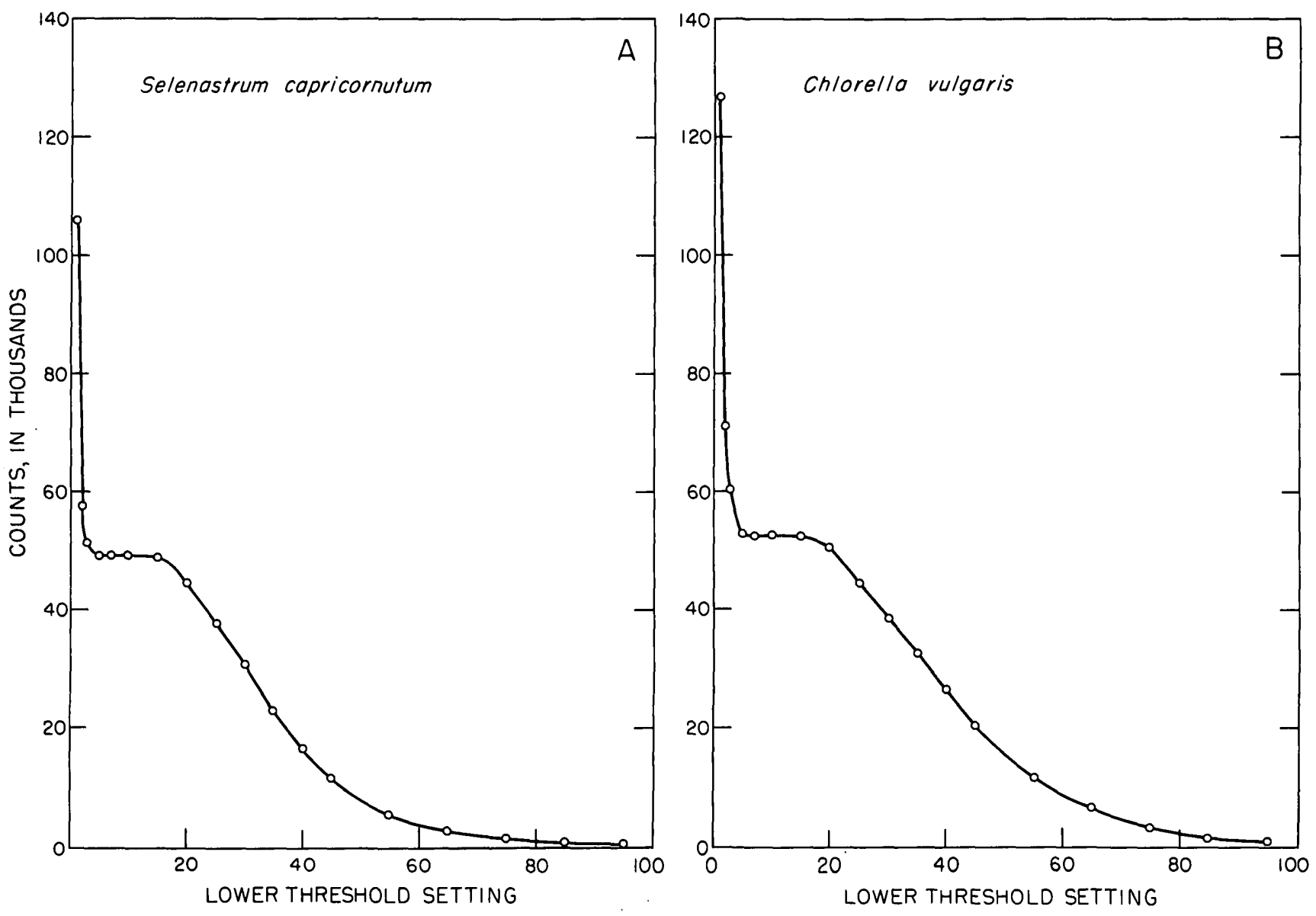

Figure 1.-Lower threshold settings plotted against number of counts for S. capricornutum (A) and C. vulgaris (B). The settings for the reciprocal amplification and aperture-current switches were 2 and $1 / 4$, respectively; the upper threshold switch was disengaged.

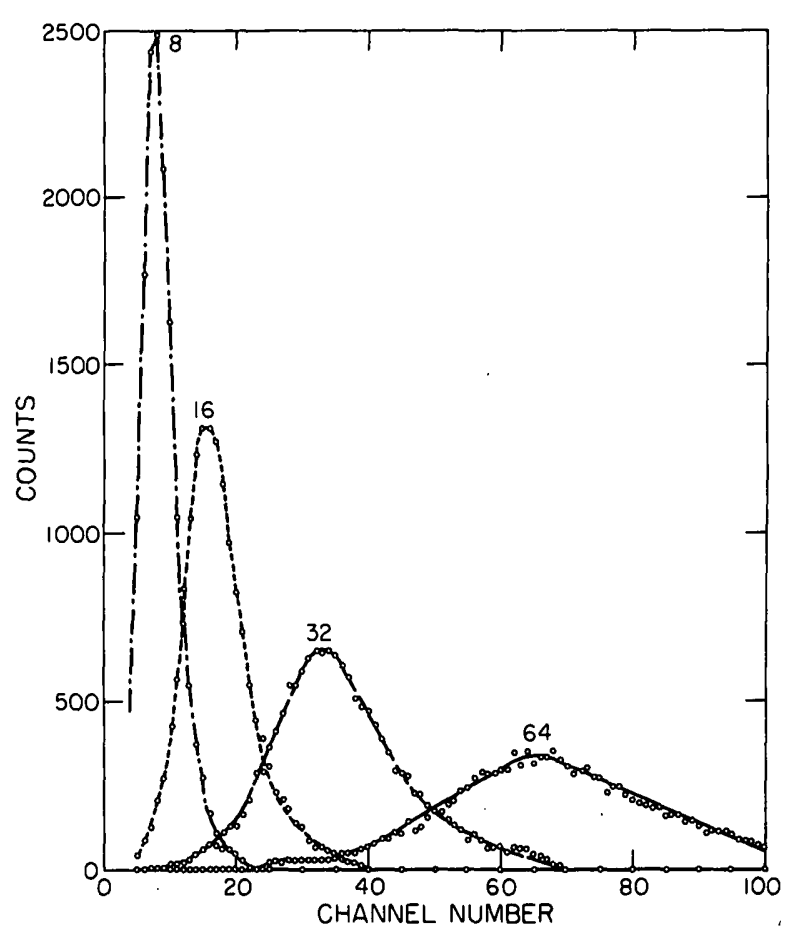

table 1. C. reinhardtii displayed a greater than fourfold increase in average particle (cell) size from an average size of $40 \mu \mathrm{m}^{3}$ to $190 \mu \mathrm{m}^{3}$. When the measurement of this change was incorporated with the change in cell counts and the gravimetrically determined microgram dry weight per cubic micrometre (table 2), the maximum standing crop and maximum growth rates for $C$. vulgaris, S. capricornutum, and $C$. reinhardtii were then equivalent (figure $3 \mathrm{~B}$ ). The growth rate and maximum standing crop for $S$. quadricauda were less, although the maximum standing crop did eventually approach that of the other three. It was possible to use the gravimetrically aetermined value

Figure 2.-Changes in size distribution curves with change in amplification at a constant aperture current. The reciprocal aperture-current switch was set at $1 / 4$ and the reciprocal amplification switch was set at 8 , 4,2 , and 1 (that is, halving each setting), giving size distribution curves with peaks of $8,16,32$, and 64 , respectively. The alga used was Selenastrum capricornutum. 

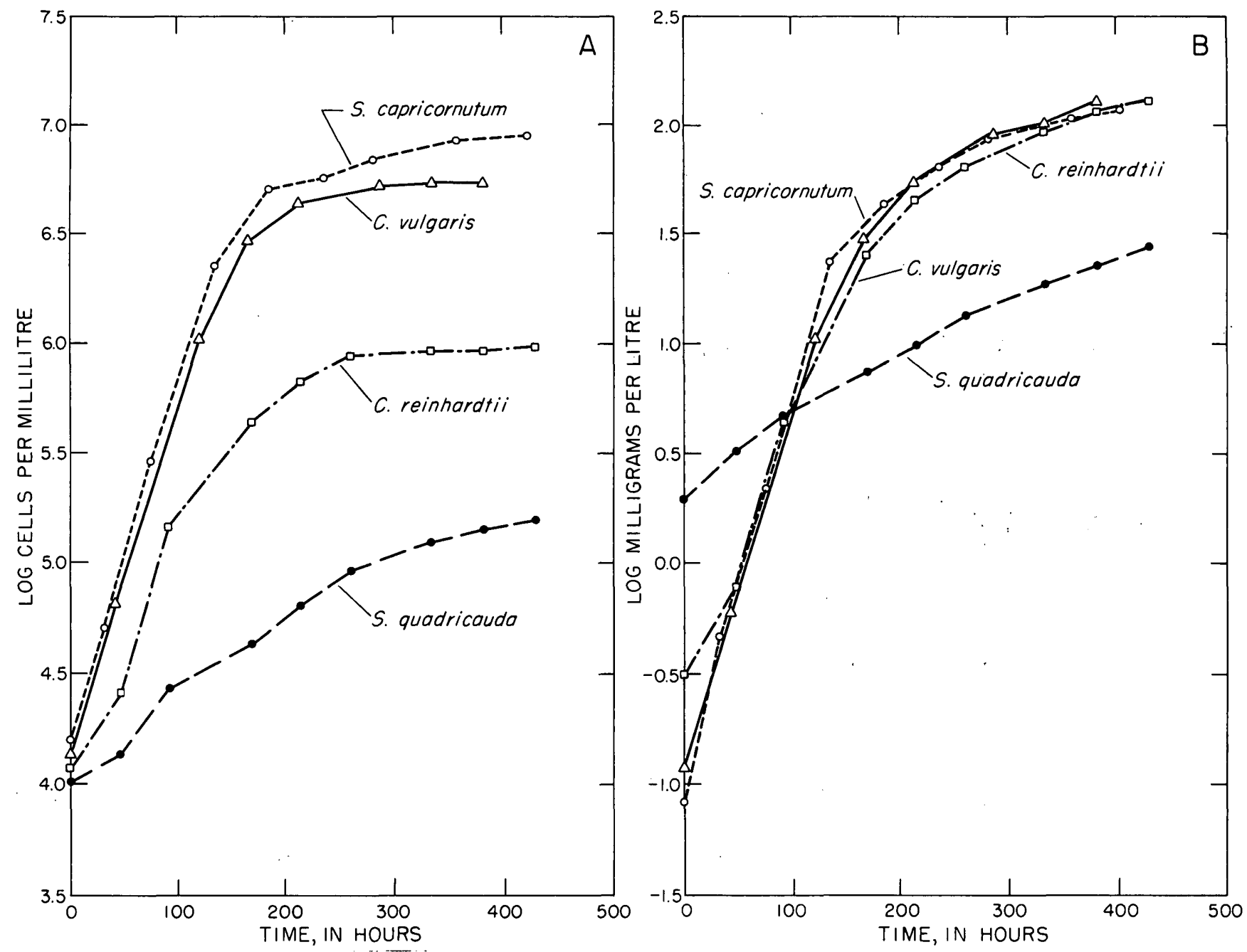

Figure 3.-Plots of logarithmic values of growth. $A$, Cell counts per millilitre versus time, using the electronic particle counter. $B$, Milligrams per litre versus time, using data obtained with electronic particle counter.

TABLE 1.-Range of average cell volumes using the electronic particle counter

Algae Range of average particle volume
from logarithmic to stationary
phase (cubic micrometre)

Chlorella vulgaris 15-41

$20-59$

$40-190$

Chlamydomonas reinhardtii ---

scenedesmus quadricauda

$380-640$

TABLE 2.-Factors in microgram dry weight per cubic micrometre, for converting count and size measurement by electronic particle counter to milligrams per litre

Algae

Chlorella vulgaris

Selenastrum capricornutum

Chlamydomonas reinhardtii

scenedesmus quadricauda

-1-----

for microgram dry weight per cubic micrometre during the growth period since the relationship between total cell volume and total cell weight was a constant (fig. 4, for C. vulgaris).
When samples were inoculated with a 6- to 8-day laboratory culture of $S$. capricornutum, the algae grew and usually maintained rather symmetrical size distribution curves, making calculations to milligram per litre from average cell volume and cell number rather simple. If, however, an inoculum was used from an older culture of $S$. capricornutum which had an average cell volume of 50 to $65 \mu \mathrm{m}^{3}$ there was a change from high average cell volumes to low average cell volumes (20 to $25 \mu \mathrm{m}^{3}$ ) which took place over a period of about 2 to 4 days after inoculation. The change is shown in the size distribution curves in figure 5. After the initial large change in average cell volume, the size distribution curve remained generally symmetrical and the average size slowly increased into stationary phase. The increase in average size usually was accompanied by a broadening of the size distribution peak. 


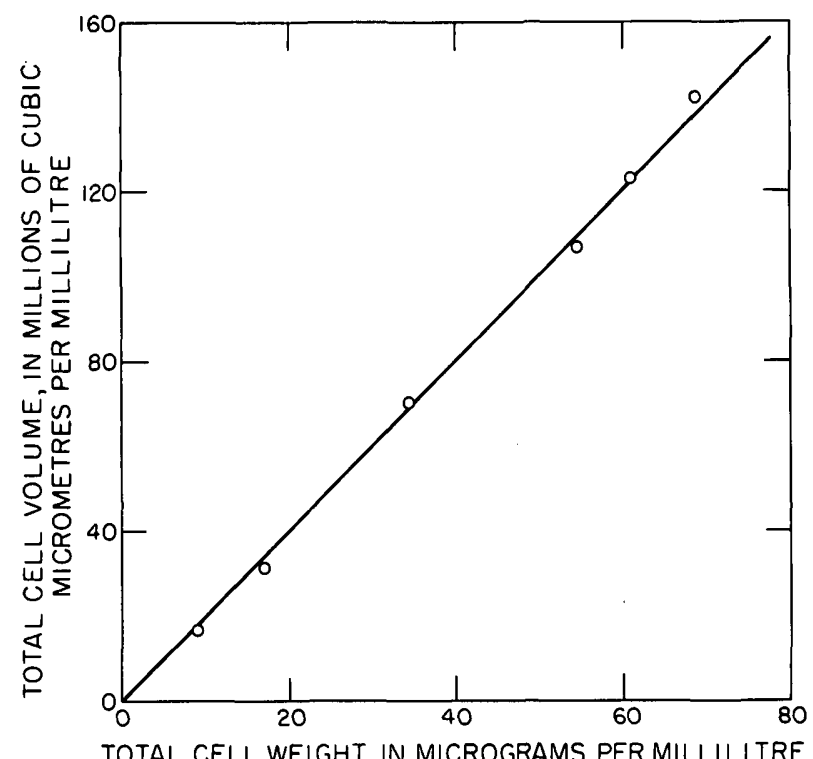

Figure 4.-The relationship between total dry weight and total cell volume determined with the electronic particle counter using Chlorella vulgaris. The mean cell volumes for the alga ranged from 20 to $40 \mu \mathrm{m}^{\mathrm{a}}$ per cell.

\section{Image analysis technique}

With this technique sample preparation was very important since it was desirable for all the algae to be in a single plane so that uniform focusing would occur. This was particularly important when area or length measurements were being made on an entire field; a change in focus could change the values significantly. Algae which form large colonies were difficult to count in an entire field measurement. Filamentous forms which do not have a clear outline of each individual cell likewise could not be counted accurately. This could result from all the filaments not being in the same focal plane or just a poorly defined cell wall between adjacent cells of the filament. For individual measurements of area or length, it was usually possible to focus on a single cell of a colony or filament. With some algae, such as $S$. quadricauda and $S$. capricor-

Fiaure 5.-The change in average cell volume when older algal cells are inoculated into fresh media. Cultures of Selenastrum capricornutum having an average cell volume of $55 \mu \mathrm{m}^{3}$ are inoculated into fresh media under the conditions described by Bartsch (1971). A change in cell size from 55 to $20-25 \mu \mathrm{m}^{3}$ then occurs over a period of approximately 2 days. After this time the curve with a peak at 20-25 $\mu \mathrm{m}^{3}$ slowly moves to higher values (to approximately $55 \mu \mathrm{m}^{3} /$ cell) as cell numbers increase. $A=0$ time, $B=22$ hours, $C=26$ hours, $D=30$ hours, and $E=45$ hours after inoculation. Cell counts were allowed to accumulate to 400 in the highest channel for $A$ to $E$ and thus peak heights from $A$ to $B$ or $B$ to $C$, and so on are not relative. nutum, a noticeable distortion occurred because of the sample preparation method, making area and length

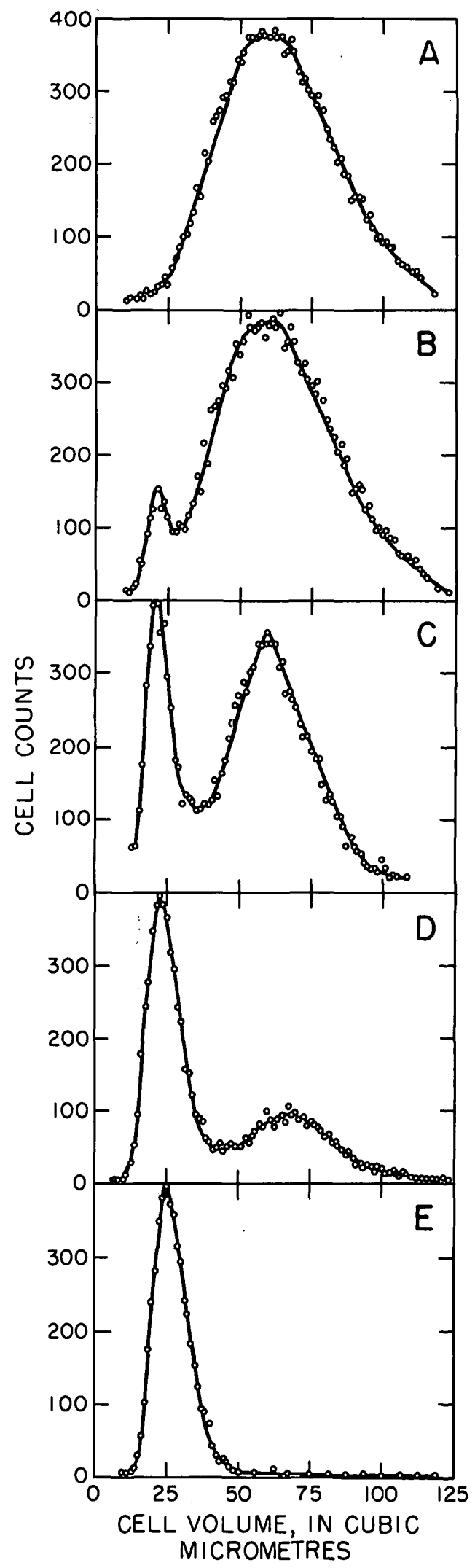


measurements and the identification of these algae difficult.

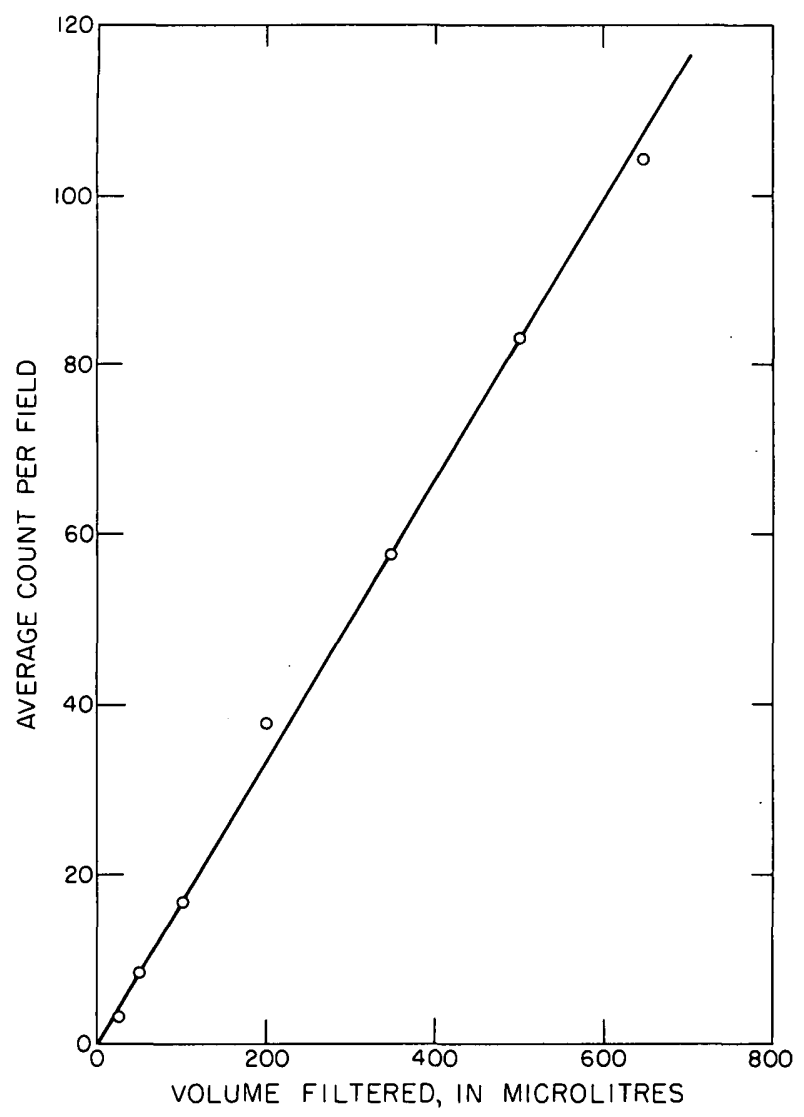

Figure 6.-Counts versus volume of algal cell suspension filtered using the image analysis technique.

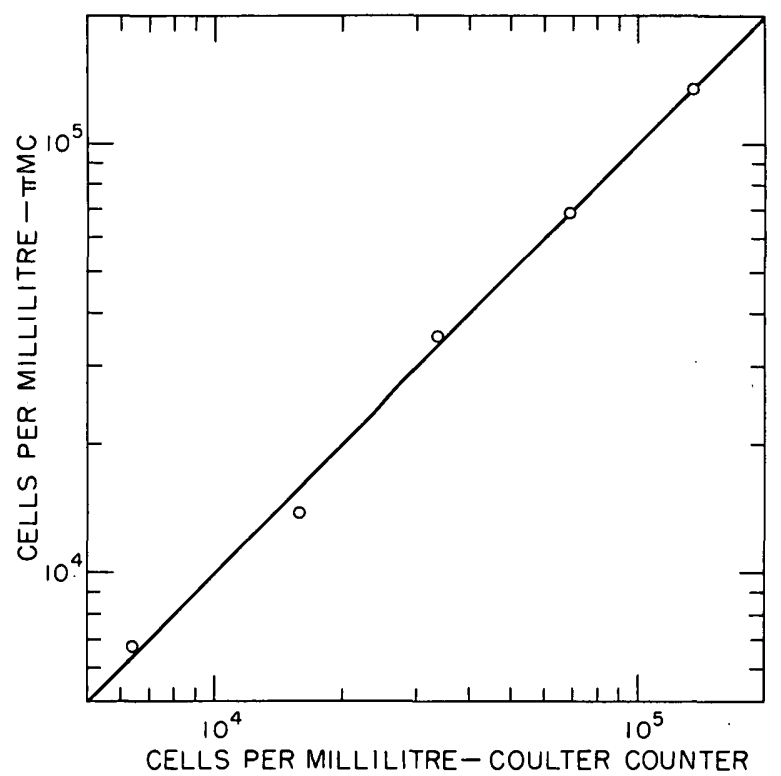

Figure 7.-Comparison of counts obtained with electronic particle counter (Coulter) and the image analyzer (Millipore $\pi \mathrm{MC}$ ). Dilutions of Chlamydomonas reinhardtii were used for counting.
To determine the range of the number of cells over which a linear response was obtainable, an increasing volume of a suspension of $C$. reinhardtii was filtered and prepared on a slide as described in the "Materials and Methods" section. A linear response in cells per field, even at very low counts, was observed over the range shown in figure 6. At higher concentrations per field however, clumping or cell overlap resulted in fewer counts than expected because the counter would count two or more overlapping cells as one. For smaller algae, a larger number of cells per field could be counted accurately.

The image analysis technique was also used to count different types of algae in a mixed culture. These were selected algae that were not grossly distorted by the sample preparation method and that could be distinguished from one another by variations in morphology. $C$. reinhardtii, $C$. vulgaris, and $A$. nidulans were the test alga.e. The counts could be separated by computing the ratio of area to length for each particle and by allowing the computer to sort and count each of

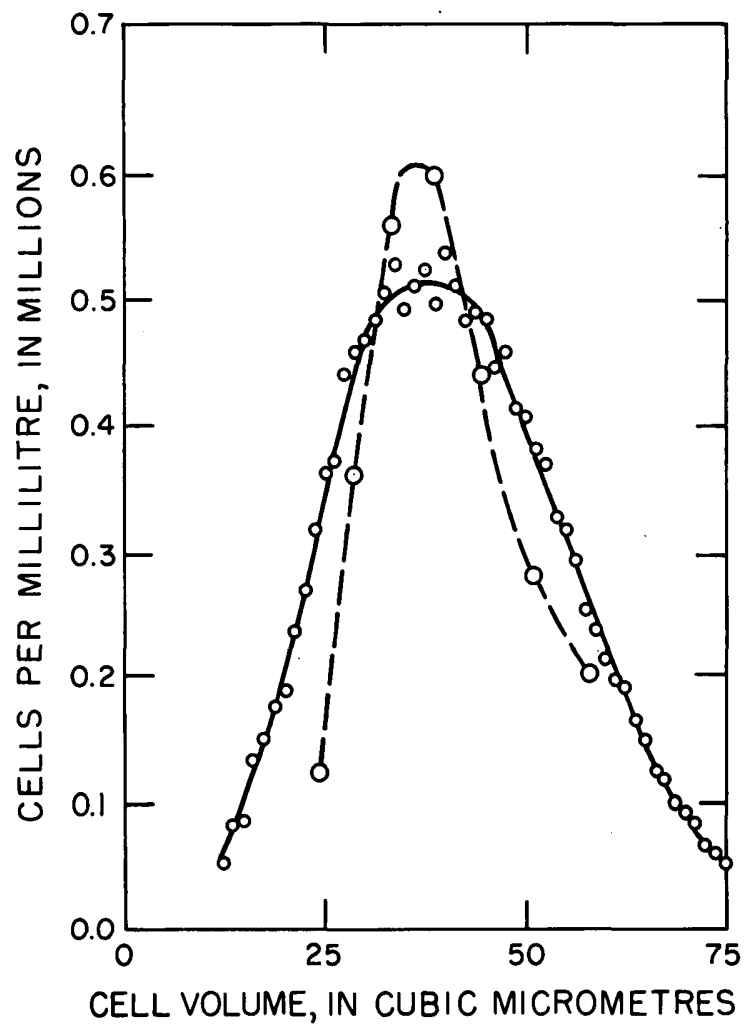

Frgure 8.-Comparison of size distribution curves obtained with the electronic particle counter and the image analyzer. A culture of Chlorella vulgaris was used in this study; small circles are volume measurements obtained with the electronic particle counter and large circles are the corresponding volumes calculated from diameter measurements obtained with the image analyzer. 
the three types. Typical ratios ranged from 5 to 7 for C. reinhardtii, 2 to 4 for $C$. vulgaris, and 0.2 to 1.3 for $A$. nidulans. Thus, depending on the ratio of a given particle, it would be placed in one of three categories. The number of types of algae to be counted in a mixture would be limited only by the ability to apply shape factors without having an overlap between each type. These three algae therefore, could be used to measure algal growth potential based on inoculation of a water sample with a mixture of equal amounts of several different types of algae rather than with one particular type.

The electronic particle counting technique was compared to the image analysis technique using the green flagellate, $C$. reinhardtii, and the green alga, $C . v u l$ garis. Figure 7 shows that the counts obtained by both instruments using $C$. reinhardtii were the same. The $\log$ - $\log$ plot has a slope of one and, when extended, intercepts both axes at zero. Size distribution curves can be obtained by counting the number of cells which fall in various size classes using maxinum chord (that is, maximum length in the horizontal plane) as the variable. Because maximum chord is an orientation dependent parameter on the image analyzer and the intent was to compare size distribution curves obtained with the image analyzer to those obtainable with the electronic particle counter, the somewhat spherical alga, $C$. vulgaris was selected for study. The maximum chord could, therefore, be used as the variable and would be virtually equivalent to the cell diameter. From the formula for the volume of a sphere and these various size measurements, it was possible to calculate volume and compare results obtained with the volume measurements of electronic particle counter and size analyzer. The values obtained from such an experiment are plotted in figure 8. Identical size distribution curves were obtained with both instruments using the relatively spherical alga, $C$. vulgaris.

\section{Fluorescence measurements}

In vivo fluorescence measurements were made on two of the algae, $C$. vulgaris and $S$. capricornutum, to assess their usefulness in measuring algal growth. Graphs of logarithmic values of fluorescence versus cell numbers for both algae (fig. 9) were linear from early logarithmic to early stationary phase. At a given concentration of either algae, the same fluorescence values were found. Both plots had a slope of approximately one during this phase of growth, but the fluorescence per cell decreased with the onset of stationary phase.
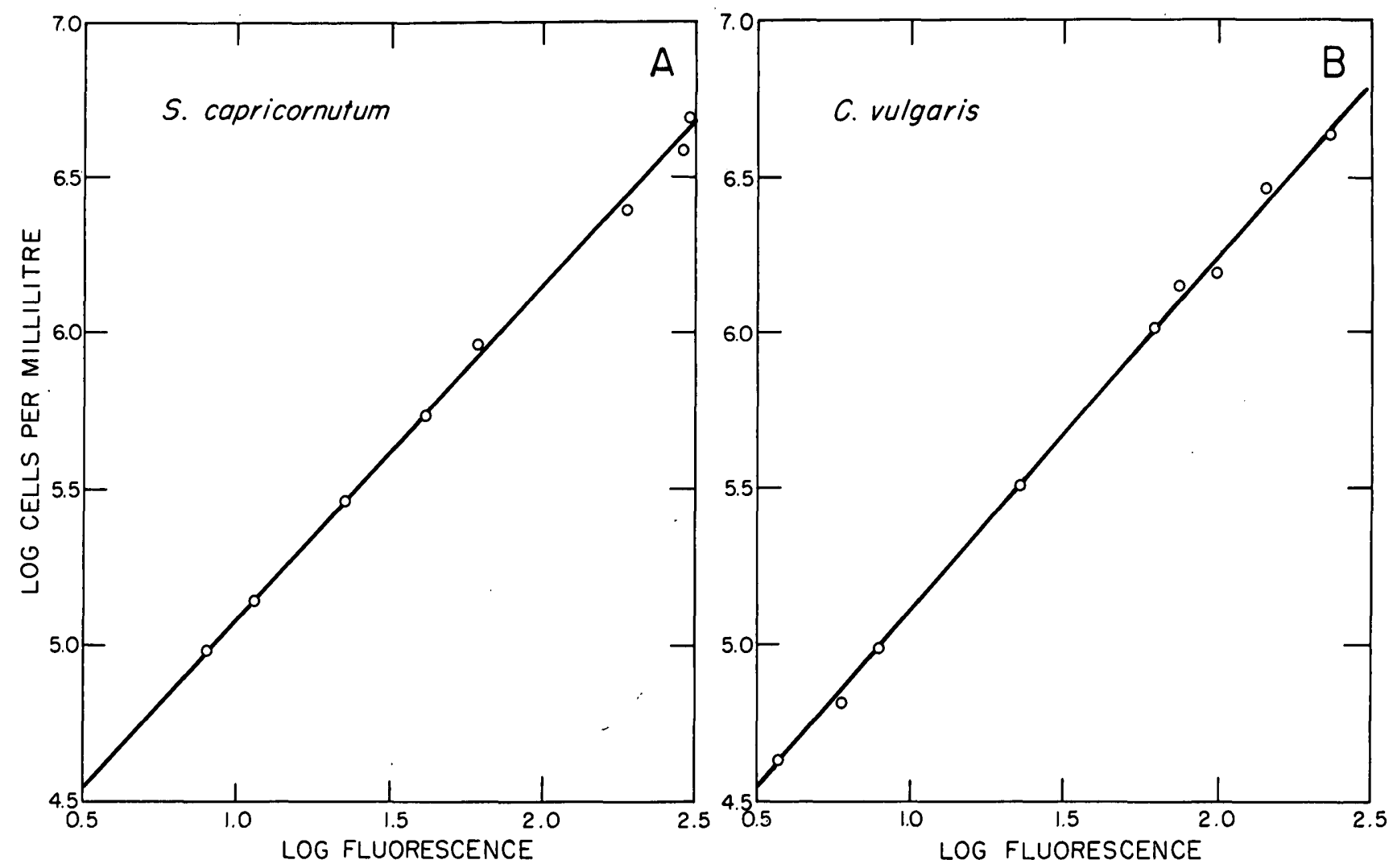

Figure 9.-The relationship between in vivo chlorophyll fluorescence and cell counts. Cells were from several different culture flasks at different stages of growth from early logarithmic to early stationary phase. 
Fluorescence measurements, therefore, could be used to obtain maximum growth rates on this culture medium, but would not be as useful for maximum standing crop values, because the relationship between cell numbers and fluorescence was not linear into stationary phase.

Although this method was sensitive and measurements could be quickly performed, chlorophyll fluorescence is not a satisfactory method for determining algal growth on water of differing chemical composition because the ratio of chlorophyll-to-cell mass varies significantly with growth on chemically differing samples (Kuhl and Lorenzen, 1964). Table 3 shows that $C$. vulgaris grown on the provisional algal assay procedures (PAAP) media with and without glucose gave a fourfold difference in the fluorescence to cell number ratio. The relationship between chlorophyll and algal

TABLE 3.-Decrease in fluorescence per algal cell (C. vulgaris) with growth on organic carbon source

\begin{tabular}{|c|c|c|}
\hline \multirow[b]{2}{*}{ Experiment } & \multicolumn{2}{|c|}{$\begin{array}{c}\text { Fluorescence per milligram } \\
\text { dry weight per lltre }\end{array}$} \\
\hline & PAAP media & $\begin{array}{c}P A A P \text { media } \\
+0.1 \text { gglucose } / 100 \mathrm{ml}\end{array}$ \\
\hline $\begin{array}{l}1 \\
2 \\
2\end{array}$ & $\begin{array}{l}4.42 \\
4.02 \\
4.92\end{array}$ & $\begin{array}{l}1.10 \\
1.11 \\
1.12\end{array}$ \\
\hline
\end{tabular}

growth was particularly poor with algae which could grow on organic carbon without producing as much chlorophyll as when grown autotrophically (Pringsheim, 1959).

\section{REFERENCES CITED}

Bartsch, A. F., 1971, Algal assay procedure-bottle test: Corvallis, Oreg., U.S. Environmental Agency, 82 p.

Hastings, J. W., Sweeney, B. M., and Mullin, M. W., 1962, Counting and sizing of unicellular marine organisms: New York Acad. Sci. Annals, v. 99, no. 2, p. 280-289.

Kuhl, A., and Lorenzen, H., 1964, Handling and culturing of Chlorella: Methods Cell Physiology, v. 1, p. 159-187.

Maloney, T. E., Miller, W. E., and Shïroyama, T., 1972, Algal responses to nutrient additions in natural water, $I$. laboratory assays, in Nutrients and eutrophication: Am. Soc. Limnology and Oceanography Spec. Symposium, v. 1, p. 134-140.

Pringsheim, E. G., 1959, Heterotrophie bei algen und flagellaten, in Ruhland, W., ed., Handbuch der Pflanzenphysiologie : Berlin, Springer Pub. Co., v. 9, p. 303-326.

Starr, R. C., 1964, The culture collection of algae at Indiana University: Am. Jour. Botany; v. 51, no. 9, p. 1013-1044.

Wang, W. C., Sullivan, W. T., and Evans, R. L., 1972, A technique for evaluating algal growth potential in Illinois surface water: Urbana, Illinois Water Survey, Rept. Inv. 72. $16 \mathrm{p}$. 


\section{RECENT PUBLICATIONS OF THE U.S. GEOLOGICAL SURVEY}

(The following books may be ordered from the Branch of Distribution, U.S. Geological Survey, 1200 South Eads Street, Arlington, VA 22202 (an authorized agent of the Superintendent of Documents, Government Printing Office). Payment is required. Remittances should be sent by check or money order payable to U.S. Geological Survey. Give series designation and number, such as Bulletin 1368-A, and the full title. Prices of Government publications are subject to change. Increases in costs make it necessary for the Superintendent of Documents to increase the selling prices of many publications offered. As it is not feasible for the Superintendent of Documents to correct the prices manually in all the previous announcements and publications stocked, the prices charged on your order may differ from the prices printed in the announcements and publications)

\section{Professional Papers}

P 567. Dictionary of Alaska place names, by D. J. Orth. 1967. 1,084 p. $\$ 23.40$. (Reprinted 1976.)

P 569-D. Geohydrologic significance of lithofacies of the Carrizo Sand of Arkansas, Louisiana, and Texas and the Meridian Sand of Mississippi, by J. N. Payne. 1975 (1976). p. D1-D11; 9 plates in separate case. $\$ 11$.

P 655-J. Hydraulic effects of changes in bottom-land vegetation on three major floods, Gila River, in southeastern Arizona, by D. E. Burkham. 1976. p. J1-J14; plates in pocket. $\$ 2.05$.

P 774-D. Shaver Lake quadrangle, central Sierra Nevada, Calif.-Analytic data, by P. C. Bateman and J. P. Lockwood. 1976. p. D1-D20. $85 \phi$.

P 813-C. Summary appraisals of the Nation's ground-water resources-Upper Colorado Region. by Don Price and Ted Arnow. 1974. p. C1-C40 ; plates in pocket. \$3.25. (Reprinted 1976.)

P 848-D. Brachiopoda of the Amsden Formation (Mississippian and Pennsylvanian) of Wyoming, by Mackenzie Gordon, Jr. 1975 (1976). p. D1-D86; 13 plates showing fossils. \$2.95.

P 854. Middle Jurassic (Bajocian and Bathonian) ammonites from northern Alaska, by R. W. Imlay. 1976. 22 p.; 4 plates showing fossils. $\$ 1.25$.

P 858. Late Paleozoic Foraminifera from southern Chile, by R. C. Douglass and M. K. Nestell. 1976. 49 p.; 18 plates showing fossils. $\$ 2.10$.

P 890. The August and October 1968 east rift eruptions of Kilauea Volcano, Hawaii, by D. B. Jackson, D. A. Swanson, R. Y. Koyanagi, and T. L. Wright. 1975 (1976). 33 p. $\$ 1.30$.

P 891. The February 1969 east rift eruption of Kilauea Volcano, Hawail, by D. A. Swanson, D. B. Jackson, R. Y. Koyanagi, and T. L. Wright. 1976. $30 \mathrm{p}$.; plate in pocket. $\$ 2.05$.
P 978. PACER-Data entry, retrieval, and update for the National Coal Resources Data System (Phase I), by $\mathbf{S}$. M. Cargill, A. C. Olson, A. L. Medlin, and M. D. Carter. 1976. 107 p. $\$ 2.20$.

Bulletins

B 1291. The geologic story of the Uinta Mountains, by W. $\mathbf{R}$. Hansen, 1969. 144 p. \$3.40. (Reprinted 1976.)

B 1398. Recent landslides in Alameda County, Calif. (194071) : An estimate of economic losses and correlations with slope, rainfall, and ancient landslide deposit, by $T$. $H$. Nilsen, F. A. Taylor, and E. E. Brabb. 1976. 21 p.; plate in pocket. $\$ 1.65$.

B 1405-C. Revision of the lower part of the Tertiary System in the central and western Uinta Basin, Utah, by $\mathbf{T}$. $\mathbf{D}$. Fouch. 1976. p. C1-C7. \$1.

B 1405-F. The Buffalo Peaks Andesite of central Colorado, by G. F. Sanders, Jr., G. R. Scott, and C. W. Naeser, 1976. p. F1-F8. $\$ 1.40$.

B 1412. Coal resources of the United States, January 1, 1974, by Paul Averitt. 1975. 131 p. $\$ 1.60$. (Reprinted 1976.)

\section{Water-Supply Papers}

W 1798-M. Sediment characteristics of five streams near Harrisburg, Pa., before highway construction, by L. A. Reed. 1976. p. M1-M29. 65\%.

W 1798-0. Sediment characteristics of streams in the eastern Piedmont and western Coastal Plain regions of North Carolina, by C. E. Simmons. 1976. p. 01-032. $\$ 1.40$.

W 2113. Surface water supply of the United States, 1966-70 -Part 5, Hudson Bay and Upper Mississippi River basin -Volume 1, Hudson Bay region. 1976. 425 p. $\$ 4.10$.

W 2158. Quality of surface waters of the United States, 1970. Parts 9 and 10. Colorado River basin and the Great Basin. 1976. 371 p. $\$ 3.40$. 
POSTAGE AND FEES PAID PUBLIC DOCUMENTS DEPARTMENT U.S. GOVERNMENT WASHINGTON, D.C. 20402 PRINTING OFFICE

OFFICIAL BUSINESS 